\title{
MAIN STREET
}

$A N D$

WALL STREET

8

WILLIAM Z.RIPLEY 
Teperty of U hand tehenker

From the collection of the

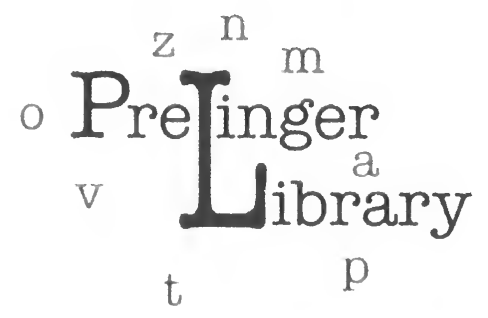

San Francisco, California 2006 



\section{Digitized by the Internet Archive in 2006 with funding from Microsoft Corporation}




\section{MAIN STREET \\ AND WALL STREET}





\title{
MAIN STREET \\ AND WALL STREET
}

\author{
BY \\ WILLIAM Z. RIPLEY \\ Nathaniel Ropes Professor of Political Economy \\ Harvard University
}

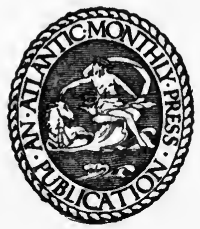

BOSTON

LITTLE, BROWN, AND COMPANY

I 927 
Copyright, 1926, 1927,

By William Z. Ripley

All rights reserved

Published February, 1927

Reprinted February, 1927

THE ATLANTIC MONTHLY PRESS PUBLICATIONS

ARE PUBLISHED BY

LITTLE, BROWN, AND COMPANY

IN ASSOCIATION WITH

THE ATLANTIC MONTHLY COMPANY

PRINTED IN THE UNITED STATES OF AMERICA 


\section{PERSONAL NOTE}

THIs book is not just a treatise on economics; nor is it a handy manual for investors. It purports to go deeper than that, down toward the root of things. It is partly the expression of a lifelong aspiration to promote a greater equality of opportunity among men - a more even chance at getting a living all round, and a fairer show at conserving the fruits of such activity thereafter. Only thus can there be any real pleasure in work and in thrift in the world. And it is upon the reasonable exercise of these virtues that our American democratic polity must depend for its perpetuation. It should be a prime function of government to stimulate and in every way to protect the manifestation of these basic instincts. Property should never be allowed to degenerate into an instrument of oppression. Its only justification in a free state is that it shall contribute to such an equality of opportunity for all members of the community alike, that each one shall be more able to take care of and to make the best of himself.

This, then, is really a study in the relation of property to civilization. My theory of it could not be more pithily stated than in the following characterization of William Cobbett by G. K. Chesterton:-

He would have been as ready as any merchant or trader to face the fact that man, as God has made him, must make money. But he had a vivid sense that the money must be as solid and honest as the corn and fruit for which it stood, that it must be closely in touch with the realities that it represented; and he waged a furious war on all those intricate and sometimes imaginary processes of debts and shares and promises and per- 
centages which make the world of wealth to-day a world at the worst unreal and at the best unseen. . . But what he was at once predicting and denouncing, like a small cloud that had not yet become a universal fog, was that vast legal fiction that we call finance. In any case, against a world in which such financial mysteries were multiplying every day, in which machinery was everywhere on the march, and the new towns spreading with the swiftness of a landslide ... against the whole great crawling labyrinth of the modern state which is almost one with the modern city.

And yet, in contradistinction to Cobbett, I would prefer the weapon of honey rather than that of sting. These essays are not "attacks." This is not a so-called muckraking enterprise. Never perhaps in the history of the world have so many constructive forces been assembled in one country at one time as in the United States during this present prolonged period of prosperity. All the more reason, then, that with full acknowledgment of what is so sound and wholesome, we should inquire deeply concerning those things which might better serve the common good than is now the case.

Nor is the underlying thought in this overnight study by any means new. One finds it notably in Brandeis's Other People's Money, which was concerned primarily, however, with then existing railroad conditions; in Veblen's Absentee Ownership and Business Enterprise, most stimulating, but perhaps too promiscuously accusative; and in Lippmann's Drift and Mastery, presenting the issues in a striking literary way. By no means insignificant, also, was the work of the New York State Life Insurance Commission of I9I0, under the masterful direction of Mr. Charles E. Hughes. But it is the application of these recognized general principles to the specific post-war period of prosperity in which we are now living which justifies this further development of the topic. Without the Liberty Loan campaigns, leading to the great 
increase of popular investment in business and other corporations, there would have been no need of reiterating and further emphasizing the same thesis. The surprising development of employee ownership of corporate securities and the spread of customer ownership among the electrical public utilities have redirected attention thereto. But most persistent and striking of all has been the tendency, since the depression of I920, toward the transformation of hitherto purely personal businesses, closely owned, into very widely held and loosely governed public enterprises. This it is which brings the problem of corporate organization and government into such peculiar prominence at this time.

I have confessed the theft of a part of my title to Mr. Sinclair Lewis, the distinguished author of Main Street. He has been pleased to send me his "Godspeed" in the enterprise. To a host of others I am also indebted in many ways. The only possible reparation will be that, despite its manifest shortcomings, the volume shall stimulate discussion and inquiry. That it may bring forth fruit in due season is my most earnest wish. 


\section{CONTENTS}

PAGE

Personal Note . . . . . . . . . v v

I Before the War: How Things Looked Then. By Woodrow Wilson . . . . . . . . . . 3

II Corporate Vehicles: Post-War Engines of Finance . . . . . . . . . . . $\mathrm{I} 6$

III Getting Out from Under: Various Angles of It 55

IV Giving Up Control: A Birthright for Pottage 78

V New Thoroughares: A Way Out? . . . . in 8

VI Light at the Crossways: Stop, Look, Listen! · 156

VII Impublicity: What to Do about It . . . . 208

VIII Our Railroads: Safe Financial Common CarRIERS . . . . . . . . . . 229

IX Planning Ahead, or Happy-Go-Lucky - Which? 255

X More Light; and Power, Too! . . . . . . . 276

Xi Public Utilities: Still More about Them . . 3io

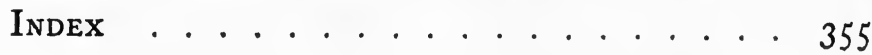





\section{MAIN STREET \\ AND WALL STREET}





\section{Ihe}

I

\section{BEFORE THE WAR \\ HOW THINGS LOOKED THEN ${ }^{1}$ \\ By WoOdrow WiLson}

WE have witnessed in modern business the submergence of the individual within the organization, and yet the increase to an extraordinary degree of the power of the individual - of the individual who happens to control the organization. Most men are individuals no longer so far as their business, its activities or its moralities, is concerned. They are not units, but fractions; with their individuality and independence of choice in matters of business they have lost also their individual choice within the field of morals. They must do what they are told to do, or lose their connection with modern affairs. They are not at liberty to ask whether what they are told to do is right or wrong. They cannot get at the men who ordered it - have no access to them. They have no voice of counsel or of protest. They are mere cogs in a machine which has men for its parts. And yet there are men here and there with whom the whole choice lies. There are men who control the machine as a whole and the men who compose it. There are men who use it with an imperial freedom of design, whose power and whose individuality overtop whole communities. There is more individual power than ever, but those who exercise it are few and

1 Annual Address, American Bar Association, Chattanooga, Tenn., IgIo. Reports, pp. 426-434, 439. Reprinted by permission. 
formidable, and the mass of men are mere pawns in the game.

The present task of the law is nothing less than to rehabilitate the individual - not to make the subordinate independent of the superior, not to turn corporations into debating societies, not to disintegrate what we have been at such pains to piece together in the organization of modern industrial enterprise, but to undo enough of what we have done in the development of our law of corporations to give the law direct access again to the individual - to every individual in all his functions.

Corporations do not do wrong. Individuals do wrong, the individuals who direct and use them for selfish and illegitimate purposes, to the injury of society and the serious curtailment of private rights. Guilt, as has been very truly said, is always personal. You cannot punish corporations. Fines fall upon the wrong persons; more heavily upon the innocent than upon the guilty; as much upon those who knew nothing whatever of the transactions for which the fine is imposed as upon those who originated and carried them through - upon the stockholders and the customers rather than upon the men who direct the policy of the business. If you dissolve the offending corporation, you throw great undertakings out of gear. You merely drive what you are seeking to check into other forms or temporarily disorganize some important business altogether, to the infinite loss of thousands of entirely innocent persons and to the great inconvenience of society as a whole. Law can never accomplish its objects in that way. It can never bring peace or command respect by such futilities.

I regard the corporation indispensable to modern business enterprise. I am not jealous of its size or might

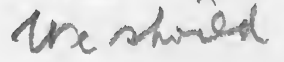


if you will but abandon at the right points the fatuous, antiquated, and quite unnecessary fiction which treats it as a legal person; if you will but cease to deal with it by means of your law as if it were a single individual not only, but also - what every child may perceive it is not - a responsible individual. Such fiction and analogies were innocent and convenient enough so long as corporations were comparatively small and only one of many quite as important instrumentalities used in business, only a minor item in the economic order of society. But it is another matter now. They span society, and the responsibilities involved in their complex organization and action must be analyzed by the law as the responsibilities of society itself, in all its other aspects, have been.

The corporations now overshadow partnerships altogether. Still more do they overshadow all individuals engaged in business on their own capital and separate responsibility. It is an arrangement by which hundreds of thousands of men who would in days gone by have set up in business for themselves put their money into a single huge accumulation and place the entire direction of its employment in the hands of men they have never seen, with whom they never confer. These men, these quite autocratic managers, are thereby made, as it were, multiple individuals. In them are concentrated the resources, the choices, the opportunities, in brief, the power of thousands. They could never of themselves, of their own effort and sagacity, have accumulated the vast capital they employ, and employ as if it were their own; and yet they have not the full legal responsibilities of those who supplied them with it. Because they have the power of thousands they have not the responsibility 
common to those whose poyer they use! It is an extraordinary anomaly!

A modern corporation is an economic society, a little economic state - and not always little, even as compared with states. Many modern corporations wield revenues and command resources which no ancient state possessed, and which some modern bodies politic show no approach to in their budgets. The economic power of society itself is concentrated in them for the conduct of this, that, or the other sort of business. The functions of business are differentiated and divided amongst them, but the power for each function is massed. In some instances even the functions are not separated. Railroad companies have been known to buy coal mines. Manufacturing combinations have been observed to develop a score of subsidiary industries, to spread a network of organization over related enterprises, and sometimes even over enterprises whose relation to their main undertakings it is difficult for the lay mind to perceive. Society, in short, has discovered a new way of massing its resources and its power of enterprise, is building up bodies economic outside its bodies politic which may, if we do not find the means to prevent them, the means of disclosing the responsibilities of the men who compose them, dominate bodies politic themselves.

And these huge industrial organizations we continue to treat as legal persons, as individuals, which we must not think of as consisting of persons, within which we despair of enabling the law to pick out anybody in particular to put either its restraint or its command upon! It is childish, it is futile, it is ridiculous! One thinks of the old Confederation, which we had to abandon because it tried to govern states and could not command individ- 
uals. As well treat society itself as a unit; insist that it impose a fine upon itself for every wrong done, no matter how notorious it may be who did it; suggest that it embarrass all its processes of action and even break itself up into its constituent parts and begin all over again when the persons whom it has trusted prove depraved or selfish. It is not even interesting to continue such an experiment.

Society cannot afford to have individuals wield the power of thousands without personal responsibility. It cannot afford to let its strongest men be the only men who are inaccessible to the law. Modern democratic society, in particular, cannot afford to constitute its economic undertakings upon the monarchial or aristocratic principle and adopt the fiction that the kings and great men thus set up can do no wrong which will make them personally amenable to the law which restrains smaller men: that their kingdoms, not themselves, must suffer for their blindness, their follies, and their transgressions of right.

It does not redeem the situation that these kings and chiefs of industry are not chosen upon the hereditary principle (sometimes, alas! they are) but are men who have risen by their own capacity, sometimes from utter obscurity, with the freedom of self-assertion which should characterize a free society. Their power is none the less arbitrary and irresponsible when obtained. That a peasant may become king does not render the kingdom democratic.

I would not have you think that I am speaking with a feeling of hostility towards the men who have in our day given the nation its extraordinary material power and prosperity by an exercise of genius such as in days 
gone by was used, in each great age, to build empires and alter the boundaries of states. I am drawing no indictment: no indictment that I could draw would be just. No indictment that has been drawn has been just, but only exaggerated and disquieting. The time for hostilities has gone by. The time for accommodations, for common understandings, for a surcease of economic warfare and the inauguration of the peace that will come only by common sacrifice and concessions, has come. I am simply trying to analyze the existing constitution of business in blunt words of truth, without animus or passion of any kind, and with a single, clear purpose.

That purpose is to recall you to the service of the nation as a whole, from which you have been drifting away; to remind you that, no matter what the exactions of modern legal business, no matter what or how great the necessity for specialization in your practice of the law, you are not the servants of special interests, the mere expert counsellors of this, that, or the other group of business men, but guardians of the general peace, the guides of those who seek to realize by some best accommodation the rights of men. With that purpose in view, I am asking you to look again at the corporation.

It is an indispensable convenience; but is it a necessary burden? Modern business is no doubt best conducted upon a great scale, for which the resources of a single individual are manifestly insufficient. Money and men must be massed in order to do the things that must be done for the support and facilitation of modern life. Whether energy or economy be your standard, it is plain enough that we cannot go back to the old competitive system under which individuals were the competitors. 
Wide organization and coöperation have made the modern world possible and must maintain it. They have developed genius as well as wealth. The nations are richer in capacity and in gifts comparable to the higher gifts of statesmanship because of them and the opportunities they have afforded exceptional men. But we have done things in pursuit of them, and have nursed notions regarding them, which are no necessary part of what we seek. We can have corporations, can retain them in unimpaired efficiency, without depriving law of its ancient searching efficacy, its inexorable mandate that men, not societies, must suffer for wrongs done. The major premise of all law is moral responsibility, the moral responsibility of individuals for their acts and conspiracies; and no other foundation can any man lay upon which a stable fabric of equitable justice can be reared.

I call your attention to the fact, therefore, that it is perfectly possible to have corporations and serve all the necessities and conveniences of modern society by means of the great combinations of wealth and energy which we have found to be so excellent, and yet dispense with a large part of the quite outworn and now in many respects deeply demoralizing fiction that a corporation is an indivisible person. Of course we must continue to regard it as an artificial person so far as is necessary to enable it to hold such property as may be proper for the execution of its charter purposes, to sue and be sued, and to conduct its business through officers who speak for it as a whole, and whose signatures and orders are, under its by-laws and resolutions, binding upon it. It must act and live as a person, and must be capable of enjoying, what individuals cannot enjoy, a certain perpetuity of power and authority, though individual men within it come and go, 
live, die, resign, or are translated. But there its unity should stop.

In respect of the responsibility which the law imposes in order to protect society itself, in order to protect men and communities against wrongs which are not breaches of contract but offenses against the public interest, the common welfare, it is imperative that we should regard corporations as merely groups of individuals, from which it may, perhaps, be harder to pick out particular persons for punishment than it is to pick them out of the general body of unassociated men, but from which it is, nevertheless, possible to pick them out - possible not only, but absolutely necessary if business is ever again to be moralized. Corporations must continue to be used as a convenience in the transaction of business, but they must cease to be used as a covert for wrongdoers.

The managers of corporations themselves always know the men who originated the acts charged against them as done in contravention of the law; is there no means by which their names may be disclosed to the officers of justice? Every act, every policy in the conduct of the affairs of a corporation originates with some particular officer, committee, or board. The officer, the committee, the board which orders an act or originates a policy contrary to the law of the land or intended to neutralize or contravene it is an insurgent against society: the man or men who originate any such act or policy should be punished, and they alone. It is not necessary that the corporation should be broken up. It is not fair that the stockholders should be mulcted in damages. If there are damages to be paid they should be paid out of the private means of the persons who are really guilty. An analysis of the guilt is perfectly feasible. It is the duty of lawyers, 
of all lawyers, to assist the makers of law and the reformers of abuses by pointing out the best and most effective way to make it.

It seems to me absurd, for example (let me say by way of parenthesis), to extend the law of libel to corporations; to suffer one publishing corporation to sue another for defamation. Somebody in particular has uttered the libel, somebody in particular has been libeled. 'Character cannot be incorporated; writing cannot be corporately done. Are lawyers so incapable of ascertaining the facts that they cannot find out who it is that did the thing or who it is that has been injured in his reputation?

I know that the matter is not as simple as it sounds. I know that some corporations are in fact controlled from the outside, not from the inside; that it often happens that some man or some small group of men who are not even in its directorate dictate its policy, its individual acts, its attitude towards law and society, and that the men who act within it are little better than automata. But are they really beyond discovery? On the contrary, is it not generally matter of common knowledge who they are? Would it take extraordinary acumen and intelligence to devise laws which would reach them also? What we are after, of course, is to obtain laws which will prevent the use of corporations to the public hurt and disadvantage. We know that the man who shoots his enemy was not in the gun, that he simply used it, and that no part of the mechanism of the gun itself is criminally liable. We can generally discover who used the gun and how he used it, whatever his cunning and secrecy. We can also find out who uses the corporations against the public interest; and we can punish him, or them, if we will, whether they belong to the actual nominal organization 
of the corporation or not. Our processes of evidence may have to be considerably altered, but we can alter them; our formal conception of parties in interest may have to be extended, but it is easy to extend it; our make-believe that we can see nobody in the transaction but those who are avowed and formal members of the organization may have to be discarded, but that ought to be a relief to our consciences. We have allowed ourselves to be ridiculously limited and embarrassed by the theory that a corporation is an indivisible person not only, but that nobody outside of it, no matter how intimate his use and control, may be brought into the suit by any genteel lawyer bred in the orthodox schools of law. A corporation is merely a convenient instrument of business and we may regulate its use as we please, and those who use it. Here is merely an artificial, a fictitious person, whom God did not make or endow, which we ourselves have made with our own hands and can alter as we will. I see no law of nature in our way, but only some laws of evidence and of corporate theory which we have outgrown.

You will say that in many instances it is not fair to pick out for punishment the particular officer who ordered a thing done, because he really had no freedom in the matter: that he is himself under orders, exercises no individual liberty of choice, is a dummy manipulated from without. I reply that society should permit no man to carry out orders which are against law and public policy, and that, if you will but put one or two conspicuous dummies in the penitentiary, there will be no more dummies for hire. You can stop the traffic in dummies, and then, when the idea has taken root in the corporate mind that dummies will be confiscated, pardon the one or two innocent men who may happen to have got into jail. 
There will not be many, and the custom of the trade will change!

There are other corporate matters worthy of your attention, but they do not intimately concern my present theme. I think you must admit, for example, that the position of the minority stockholder is, in most of our states, extremely unsatisfactory. I do not wonder that he sometimes doubts whether corporate stocks are property at all or not. He does not seem to enjoy any of the substantial rights of property in connection with them. $\mathrm{He}$ is merely contributing money for the conduct of a business which other men run as they please. If he does not approve of what they do, there seems nothing for it but to sell the stock (though their acts may have depreciated its value immensely). He cannot even inquire or protest without being told to mind his own business the very thing he was innocently trying to do! There are many things which are not satisfactory about this putting the money of many men into one pile for the use of a board of directors, and to my mind it is clearly your task as counsellors of society to make them satisfactory. It is the duty of our profession to see to it that no man's powers exceed or lie outside of his legal and personal responsibilities - that the corporation be made a mere convenience of business and not a means of irresponsible mastery, its interior and all men within it as accessible to the law as its exterior and the scattered individuals who have no corporate ambush from which to work their will.

We are upon the eve, gentlemen, of a great reconstruction. It calls for creative statesmanship as no age has done since that great age in which we set up the government under which we live, that government which was 
the admiration of the world until it suffered wrongs to grow up under it which have made many of our own compatriots question the freedom of our institutions and preach revolution against them. I do not fear revolution. I do not fear it even if it comes. I have unshaken faith in the power of America to keep its self-possession. If revolution comes, it will come in peaceful guise, as it came when we put aside the crude government of the Confederation and created the great federal state which governed individuals, not corporations, and which has been these hundred and thirty years our vehicle of progress. And it need not come. I do not believe for a moment that it will come. Some radical changes we must make in our law and practice. Some reconstructions we must push forward which a new age and new circumstances impose upon us. But we can do it all in calm and sober fashion, like statesmen and patriots. Let us do it also like lawyers. Let us lend a hand to make the structure symmetrical, well-proportioned, solid, perfect. Let no future generation have cause to accuse us of having stood aloof, indifferent, half hostile, or of having impeded the realization of right. Let us make sure that liberty shall never repudiate us as its friends and guides. We are the servants of society, the bond servants of justice.

And it is part of its definiteness and reality that liberty is always personal, never aggregate; always a thing inhering in individuals taken singly, never in groups or corporations or communities. The indivisible unit of society is the individual. $\mathrm{He}$ is also the indigestible unit. $\mathrm{He}$ cannot be merged or put into combination without being lost to liberty, because lost to independence. Make of him a fraction instead of an integer, and you have 
broken his spirit, cut off the sources of his life. That is why I plead so earnestly for the individualization of responsibility within the corporation, for the establishment of the principle by law that a man has no more right to do wrong as a member of a corporation than as an individual. Establish that principle, cut away the undergrowth of law that has sprung up so rankly about the corporation and made of it an ambush and covert, and it will give every man the right to say $N o$ again, to refuse to do wrong, no matter who orders him to do it. It will make a man of him. It is in his interest no less than in the interest of society, which must see to it that wrongdoing is put a stop to. 


\section{II \\ CORPORATE VEHICLES \\ POST-WAR ENGINES OF FINANCE}

The United States is not infrequently pictured to the world at large by travelers from abroad as a land of milk and honey, of material well-being where plumbing, radio sets, and Ford cars abound. Our achievements in the field of music, poetry, and philosophy are acknowledged; but there is not a due appreciation of the fact that our output in another domain of the imagination leads all the world. Chief Justice Marshall in the Dartmouth College case conceives of a corporation as "an artificial being, invisible, intangible, and existing only in contemplation of law." We turn out more of this particular transcendental product than all the rest of the universe put together. Our supremacy in the matter of wheat, hogs, cotton, and automobiles is matter of common knowledge; but the degree to which we have outstripped all creation in this particular line of politico-legal activity has not been adequately advertised.

Our annual crop of corporate charters - articles of association is another name for them - is not only the most bountiful of its kind on earth; the yield is a constantly accelerating one. This is due to the fact that there are forty-eight different sovereign commonwealths perpetrating these instruments, severally and independently, in America; whereas in the nations of Europe, even in the major industrial countries, there is but one 
such fountainhead. It is also true that the number of incorporations in some of these single states with us - not necessarily the larger or more important ones exceeds that of such great industrial countries as the United Kingdom, France, or Germany. Thus does this forthputting of American corporations multiply itself geometrically. A few figures will fortify these bald assertions. In the British Isles they are quite particular about the matter of registration of companies. In I920, there were 79,54I such corporations enrolled with the Board of Trade. Our own little state of Delaware, all alone, prides itself upon a corporate progeny, all living, of approximately 70,000 members. During the year 1920 there were II,OI I new companies registered and 254I stricken from the rolls in the United Kingdom, yielding a net increase of 8470 companies. Our own state of New York in the calendar year 1925 issued charters to 24,703 stock corporations - not including banks, insurance companies, and other non-business concerns. New Jersey, always active in this business, issued 5400 certificates of incorporation. Ohio and Illinois are typical of a group of states which sets on foot approximately 5000 companies a year apiece; and the tiny commonwealth of Delaware in 1925 was blessed with the addition of 5053 companies to its little family. None seem to have died. Massachusetts and Pennsylvania of late have averaged about 2000 new charters annually. States like Wisconsin produce in the neighborhood of I 500 . West Virginia averages about 100 corporations per month. Even North Dakota, which we deem an agricultural bailiwick, contributed a modest quota of 206 during the year 1925. South Dakota did twice as well, with 398 new charters. Quite a few states view the matter so 
lightly that no figures whatsoever are available. Nevada printed a list for 1923 covering forty-one pages of type, indicating an output of about 900 charters. But Connecticut, through its secretary, advises us that it makes no tabulation of the matter, nor is it possible to furnish any statistics on the subject. It would be a long task to ascertain by count from our forty-eight secretaries of state just what the total annual output is. But one might upon this showing venture the guess that the number would be not less than I00,000 - roughly ten times the annual authorization of limited companies in the United Kingdom.

It is not only the present total of incorporations in the United States which is surprising; the rate of acceleration of this movement is equally disconcerting. Take New York, for instance, launching 24,703 new corporations in 1925 . In 1900 the total was only about one tenth of this number; it reached the figure of 10,000 annually in 19I5, and of 15,000 annually about 1920 . The last jump of 5000 took place in the twelvemonth just elapsed. Ohio has never been conspicuous in this particular line of business. It used to incorporate over I000 concerns a year as far back as I890. The annual product today is fivefold that figure. Massachusetts, an old industrial community, was launching from 200 to 500 corporations, annually, twenty-five years ago. The total for 1925 was almost five times as many. Bumper crops always occur, of course, in times of prosperity. The tide of incorporation rises and falls along with bank clearings, railroad tonnage, and the marriage rate. But there also is an interesting ebb and flow discernible in this current, arising, as will shortly appear, from the keen competition between the different commonwealths 
for pelf and prestige. New Jersey during the nineties and for a bit thereafter was so uniquely gracious in according permission to its corporate offspring to hold stock in other companies that it easily led the procession of the states. Now it has yielded place as to leadership to several others. Maine, by reason of its scandalous laxity, had its heyday during the orgy of corporation promotion about 1900. Today, owing to keen interstate competition, it is enabled to charter only about one third as many new companies annually as before. Massachusetts was forced into the race in 1903. New York took a spurt ahead about IgI2 through the invention of the no-par stock device, and seems to have been able, thanks perhaps to its size and industrial preeminence, to have been able to maintain the leadership ever since. So it comes and goes. But the stream grows ever wider and deeper in its total flow. To its magnitude there seems to be no limit.

The fact is that the corporation in America is entirely supplanting such other forms of business organization as individual ownership or partnership. What used to be an exceptional device, confined to large enterprises, has now become the rule for all businesses, great and small. This increasing resort to the corporate device is demonstrated by the following table:-

Percentage of

industrial wage earners under corporate organization

1904

1909

I9I 4

1919

\section{Percentage value of all manufactured articles under corporate organization}

This table gives the percentages at our various manufacturing censuses of wage earners and of production

73.7

79.0

83.3

87.7

$\begin{array}{ll}70.6 & 73.7 \\ 75.6 & 79.0 \\ 80.3 & 83.3 \\ 86.5 & 87.7\end{array}$


under the corporate form of organization. It clearly portrays the rapid rise of the device. The individual concern and the partnership are rapidly approaching the vanishing point. The total number of such hold-overs will of course always be considerable, but the convincing thing is the relative insignificance of these other forms of organization taken in the aggregate. In a rough estimate of 100,000 new incorporations in 1925, it is probable that nine tenths or more are for little concerns capitalized at less than $\$ 100,000$ each. It is entirely characteristic of American conditions as a whole that the corporation should be steadily invading every branch of business down even to establishments of the smallest size; whereas in Europe to a much larger degree the limited company is still confined to enterprises of more than average magnitude.

The prevalence of the corporation in America is all the more significant in view of its history. In the British Isles, to be sure, the unpleasant experience of the people with their sovereigns had some effect for a time. Price, in his book The English Patents of Monopoly, characterizes the early promotion of corporations in England as "simply one of many shifty devices for raising money independent of parliamentary supplies." All down through the period from the accession of Elizabeth to the Civil War there was a succession of attempts to grant monopoly privileges for the conduct of various enterprises, always of course for cash. Now it was the starch makers of London, or again the manufacturers of playing cards, or it might be the silk weavers or the pin makers; all of them purchased their right to be and to do, for a price, with the express design of recovering the full amount with interest from the people at large. The 
protracted struggle for supremacy during the sixteenth and seventeenth centuries between Crown and Parliament could not but make an impression upon the attitude of the people toward this particular engine of finance and management.

By way of contrast, historically, the corporation got into ill repute in the United States for quite another reason. It seems to have been very infrequent in the early days. Out of twenty-one business corporations within the United States before the adoption of the Constitution, only two were trading companies and one was a manufacturing concern. And for long thereafter this was not the normal form of organization except for a few businesses like banking, insurance, turnpikes, and bridges. Such corporations as were seemingly inherited from the old country were of the fraudulent sort, which were conducted not individually but as joint stock companies. A large proportion of the two hundred such concerns about 1720 were more or less off color, including, for example, those two mentioned by Williston, one a company to provide for "insurance and improvement of children's fortunes," and another for "making salt water fresh." Such exceptional forms of organization served as a screen behind which individuals might work their will, as in the field of mining, lotteries, and the like. New Jersey in I79I issued a charter to the New Jersey Manufacturing Company, permitting it among other things to raise $\$ 10,000$ by lottery each year in general aid of its other manufacturing business.

Coming on down into the nineteenth century one still discerns a strong flavor of public disapproval of the corporation as applied to private business, indicating that it was still an exceptional and to a considerable extent 
a distrusted business device. The first American work on political economy, published in 1820 , has this to say upon the subject: -

Every moneyed corporation is prima facie injurious to the national wealth, and ought to be looked upon by those who have no money with jealousy and suspicion. They are, and ought to be, considered as artificial engines of power, contrived by the rich for the purpose of increasing their already too great ascendancy and calculated to destroy that natural equality among men which no government ought to lend its power in destroying. The tendency of such institutions is to cause a more unequal division of property and a greater inequality among men than would otherwise take place.

Twenty years later the governor of Massachusetts, within which commonwealth most of the existing corporations were then doing business, sent a stirring message to the Great and General Court, paying his respects to the corporation as follows: -

These societies are one of the vices of our time. They encourage speculation and fraud, mobilize landed property, overturn matrimonial arrangements, escape publicity in the transfer of real property, diminish the sense of individual responsibility, create property in mortmain, prevent all penal remedies, are lacking in moral sense, and constitute finally a grave social peril by concentrating too much power in the hands of certain of our citizens.

This was the time, it will be recalled, of the creation of corporations, not under general law, but by special act of the legislature. The records show that a large proportion of the companies formed in this particular commonwealth during fifteen years preceding the Civil War were driven out of business by the courts. Of upward of 6000 new corporations created within five years, over 4000 had to be dissolved - "mere fugitive 
organizations based upon credulity and to be plucked in transit," as Chandler in his Express Trusts puts it. For the neighboring state of New York thirty out of the forty-two companies chartered down to I 853 turned out to be frauds. It is stated that within a period of ten years five sixths of them came to a bad end. No wonder that some of the states adopted the expedient contained in a Pennsylvania charter of 1866 for the New York California Vineyard Company. Under the terms of this instrument the corporation was empowered to do business anywhere "except in Pennsylvania," the land of its birth. Poor waifs indeed many of them were, thus laid upon the public doorstep, abandoned even by their governmental progenitors.

All this time, of course, there were a few sound corporations conducting business enterprises in the field of private industry. In such branches as cotton manufacture, for instance, soon after the industrial revolution it was necessary to assemble more capital than could customarily be provided by individuals or families. Yet even for these companies the capital stocks were usually owned by those who managed the enterprise. They were largely family concerns. Shares were but rarely bought and sold. Only six of them, and those the largest of the cotton mills, were dealt in publicly on the Boston Stock Exchange in 1830, although this number increased substantially within the succeeding generation. But it was not until the quarter century after I860 that the practice of incorporation became sufficiently common to call for general laws upon the subject. Up to this time each corporation had been validated by a special charter, secured, perhaps, in too many cases through the liberal expenditure of money. But little by little the foundation 
was laid for the condition now confronting us - that of the corporation as the almost universally accepted form of legal organization for the conduct of business enterprises of every size, shape, and hue.

A second outstanding peculiarity of the American situation is a product of the twofold nature of our governmental system. This it is, indeed, which with all its merits and advantages unquestionably casts a blight not only upon our corporations but upon a wide range of other economic and social activities. The province of the Federal Government being restricted mainly to external relations and to matters of interstate commerce, there remains to each of the forty-eight states a complete sovereignty in all of the other relations of life. Under early simple conditions, with both transportation and communication between the states difficult and expensive, it was imperative that each commonwealth should be more or less a law unto itself in most matters of daily living. The colonial period and the earlier years under the Federal Government were characterized by sharp conflicts over the retention of these local powers. Licenses and taxes were sought to be continued by domestic concerns against "foreigners" over the border. An odd instance of persistence of this provincial spirit is afforded by the laws of Rhode Island concerning imprisonment for debt - a survival of the Middle Ages. But how else can a tiny jurisdiction protect its merchants in this age of buying on the installment plan? Escape over the frontier is so very easy, bearing your part-paid parlor furniture or your radio set beyond the sheriff's reach. Little by little with improvement of highways, railroads, the telegraph and telephone, geographic barriers have broken down, until the United States as a whole has 
become, practically speaking, one great market. And, of course, along with the extension of markets has come a lessening of the barriers which set off the people of one state socially from their neighbors. So far has this progressed that it is the observation of European travelers in the United States that we are more nearly homogeneous in customs, manners, and ways of doing business over a vast area than are the little compact countries of Europe. For they are set off against one another not only by mountains and rivers, but also by reason of their differing political traditions, languages, and religions. From a social point of view our danger is that of too monotonous uniformity rather than of a jarring diversity in customs, manners, and mode of thought.

Nevertheless, problems of great moment have arisen in the United States because of the divergent and conflicting laws respecting all sorts of things among the forty-eight commonwealths. The need of uniformity has already brought about federal systems of banking, in matters of bankruptcy and similar concerns. Perhaps the three most pressing problems other than that of corporate legislation have to do with public finance, family law, and labor legislation - child labor in particular. In the field of public finance all sorts of conflicts in matters of taxation or of exemption therefrom arise. Certain states derive profit from constituting themselves - Florida, for example - an asylum against the imposition of income taxes during life or of inheritance taxes at death. Safety vaults may spring up apace and old people migrate in numbers to those places favored alike by Nature climatically and by man in respect of his exercise of the taxing power. In the domain of family relations, conflicting state legislation has also brought 
forth a multitude of inconveniences and of abuses. Massachusetts, maintaining a high standard for its marriage laws, found itself exposed to attack on the one side from Rhode Island and on the other from Vermont (at least until I9I7), due to the laxity of the statutes in these two neighboring commonwealths. Brevity of residence, informality of registration or prior notice, laxity of parental control, in the little state of Vermont for many years made Bellows Falls a veritable Gretna Green for intending brides and grooms from Massachusetts. The Honeymoon Special train on the Boston and Maine Railroad got you there about noon, got you married, and safe home again, all in a jiffy. The common-law wedlock by handfasting, in New York, just over the western border, also attracted matrimonial candidates from Massachusetts, deterred by the formality of the statutes at home. Just now, because Delaware requires an interval of twenty-four hours after license, before marriage may take place, while in Maryland the wedding may occur at once, the marriage rate in Maryland is three times as high as it is over the border. Brooke County, the panhandle of West Virginia, is so inviting connubially because of its laws, that most of its weddings take place between citizens of Ohio or of Pennsylvania. Nebraska in 1922 amended its statutes, to require posting of a ten-day advance notice before issue of the license. As a result the state marriage rate dropped within two years from 9.4 to only 3.I per thousand. People simply sought and found their marital estate elsewhere. Or, had marriage been effected, how different were the requirements as respects divorce. South Carolina, at one extreme, permitted no annulment for any cause whatsoever. Other states, from Rhode Island to Nevada, permitted divorce 
for almost any cause, up to a change in the direction of the wind or temperature. It has long been and still is futile to expect any substantial abatement of the divorce evil until a greater uniformity of state legislation in these matrimonial concerns may be brought about.

Precisely similar as respects inconvenience, friction, and abuse are the conditions among the states in the domain of labor legislation. The same corporation may own mills operating for a ten-hour day or longer, with women, young persons, and children of all ages working day and night, in the Southern states, and other mills situated in Massachusetts, constrained to operate only forty-eight hours a week, employing no persons under the age of fourteen years, with the prohibition of all labor of females or children at night. Even now there is a shocking contrariety of conditions as between Massachusetts and Rhode Island. One state accords the benefit of workmen's compensation laws in cases of industrial accident; its neighbors may either be in the stage of employers' liability legislation or in a mediæval condition characterized by no legislation at all. And, to cap the climax in this regard, we have the Federal Government, with a code quite its own, functioning over, in, and through all of these forty-eight states. The conflict of laws seems to reach a climax in this particular province of labor legislation. A railway employee may be alternating all day long at five- or ten-minute intervals between jurisdiction of the United States or of an individual state as respects compensation for accidents, hours of service, or discipline. During those intervals when he is concerned with interstate business, he is subject to the laws of the United States. All the rest of the time he is merely a private citizen of an individual commonwealth. 
Or take the longshoreman, engaged in one of the most dangerous callings known. The number of accidents in the loading and unloading of ships is appalling. These men, too, all day long are passing and repassing from state territory on the pier over to the jurisdiction of the Federal Government, in the maritime zone in which the vessel floats. If one happens to fall, to be struck, burned, or maimed on one side of an imaginary line, halfway up the gangplank, he is subject to one code of laws; but on the other side of that line his rights and liabilities are defined by those of an entirely different sort. Wherever one touches it, in all of these different human contacts one runs afoul of the complications arising from our dual American system of government.

The root of much of our trouble in maintaining decent standards of corporate practice arises, too, from the same multiplicity and overlapping of jurisdictions, exemplified in these other matters of daily living. The scandalous prostitution of the sovereign power of states, whether for purposes of public revenue or merely as utilized by designing men for personal enrichment, may be illustrated by a few typical advertisements. Collier's Weekly, March 7, 1908, prints this one:-

Incorporate in Arizona, costs less than elsewhere, advantages are worth thousands. Transact business anywhere. No tax in Arizona. No stock subscriptions required before incorporating. Any kind of stock may be issued and paid up in property, leases, or anything of value, and made nonassessable. No public statement and no books need be kept for public inspection anywhere. Stockholders exempt from liability if our form is used. The great incorporating business of Arizona was built up by President Stoddard while Secretary of Arizona. Resident agent for many thousand companies. All blanks, laws, by-laws, and particulars free. Companies incorporated same 


\section{POST-WAR ENGINES OF FINANCE}

day we receive reasonable deposit on account and telegram stating name, capital, number of shares and names of first Directors. Incorporation better than partnership. Send for our latest revised pamphlet and learn the many and great advantages of having your business incorporated. Reference: Any bank in Arizona. Stoddard Incorporating Company, Box 3-7, Phœnix, Arizona.

That the business was still profitable thirteen years later appears from the following clipping from the $S c i$ entific American:-

\section{Incorporate in Arizona}

Complete in one day. Any capitalization, least cost, greatest advantages. Transact business anywhere. Laws, by-laws, and forms free.

Stoddard Incorporating Co.

Phœnix, Arizona.

Here is another from a Boston paper:-

This beats New Fersey

Charters procured under South Dakota laws for a few dollars. Write for corporation laws, blanks, by-laws, and forms to Philip Laurence, late Asst. Sec. of State, Huron, Beadle Co., So. Dakota.

This, too, from a recent number of System:-

Charters - Delaware Best, 2uickest, Cheapest, most liberal. Nothing need be paid in. Do business and hold meetings anywhere. Free forms. Colonial Charter Company, Wilmington, Del.

One finds in the legal press, "The Corporation Laws of the State of Nevada offer the greatest inducements." Some years ago the secretary of state of South Dakota officially recommended the services of the South Dakota Corporation Charter Company. The president of this concern writes, "In nineteen cases out of twenty we are 
able to get the charter into the mails within ten hours after the application is received here."

The little state of Delaware has always been forward in this chartermongering business. The charges for service by the Delaware Registration Trust Company of Wilmington "for maintaining the principal office, acting as registered agent, exposing the sign, acting as custodian of the duplicate stock ledger, giving notice of stockholders' meetings, furnishing annual report blanks," and so forth, are $\$ 50$ per year if the capital does not exceed $\$ 1,000,000$; for upward of $\$ 1,000,000$, $\$ 100$ per year. "We can complete all details here within twenty-four hours of the receipt of the papers properly executed, remittance, etc." "To facilitate the business, save time and, if desired, to prevent publicity in obtaining your charter we will furnish the three incorporators from this office, who will attend to the filing of the original certificate of incorporation, the recording of the certified copy, and will then meet in our office and hold the first meeting of incorporators and elect or select directors who may meet in your city, elect officers, and proceed with the business of your company." In the Daily Times-Star for October 20, 1926, is this inviting bit: "Simple annual reports are necessary, but they do not require disclosure of the corporation's financial affairs [our italics]. Of all the company's books and records, only an original or duplicate stock ledger must be kept in Delaware." Such are the conditions under which may be launched upon a perpetual career, not alone in Delaware but in a considerable number of our other American commonwealths, legal creations which may, among other things, commit the following acts: Hold all of the meetings of its stockholders and directors anywhere under the sun; keep 
all of its original records and accounts at its principal office anywhere; issue all the bonds it desires without further authorization from the chartering state and even without tax thereon; put forth without limit capital stock for practically any sort of consideration, cash, no cash, property, real or imaginary, or services, actual or spurious; and all of this coupled with the privilege of non-liability on the part of the shareholders for any of the debts contracted by the corporation.

Standard American practice is further illustrated by what may be done in Maine. The Corporation Trust Company "maintains fully equipped offices for the organization and representation of business corporations in all the states." At Portland, conveniently situated opposite the Union Station, is a corporate hostelry, fully adequate to maintain the reputation of the state as a popular summer resort. According to the law, shareholders' meetings must be held and records must be kept at the "principal office" of the corporation within the commonwealth. There is just a trace of humor in the further clauses of the Corporation Trust Company's advertisement: "It has spacious rooms for holding stockholders" meetings. Its facilities are adequate for handling meetings at which large numbers of proxies are presented."

A disgraceful misuse of the sovereign power of an American commonwealth, amounting in fact to a conspiracy against the citizens of foreign states, was brought to my attention some years ago in connection with the affairs of the Brazil Railway Company. This corporation was chartered in the state of Maine in 1906; and thereupon embarked upon an extensive program of railroad construction and general promotion in Brazil, Uruguay, and Bolivia. Its magnitude is indicated by the capital 
shares, issued to the amount of $\$ 40,000,000$, afterward raised to $\$ 60,000,000$. Within six years its borrowings, over and above this, amounted to about $\$ 75,000,000$. The most extraordinary thing about it was the charter. This instrument permitted the management, without approval of the shareholders, to dispose of the assets at any price; to purchase whatever property it might see fit, at any figure; to contract loans without let or hin'drance; and to issue new securities also ad lib. Eightyfive different issues were finally placed in the various capital centres of Europe. The charter solemnly provided that the meetings of the shareholders should be held at the principal office in Maine. With equal solemnity, it proceeded to require that notices of these meetings must be given at the principal office in Maine, at least ten days in advance. And, just to make assurance doubly sure, it was further provided that unless the proxies were returned three days before the stated meeting, the treasurer should be authorized to cast the vote under the direction of the president of the corporation. That allowed exactly seven days for the notices of the meeting to reach the shareholders, all of whom were in Europe, and to return the proxies in time for their effective use. Was ever a fraud more patent upon the face of it? Little wonder that the whole affair resulted in a colossal smash a tangle requiring the expert services of $\mathrm{Mr}$. Cameron Forbes, late governor of the Philippine Islands, who was appointed receiver in I9I4. At that time it was estimated that $\$ 12,000,000$ of new money would be requisite for purposes of rehabilitation. The losses in this stupendous venture have, so far as I know, never even been estimated. As for the situation in general, the denunciation of Governor Fernald of Maine, in 1909, 
of the continued practice of receipt of large revenues from incorporation as "the price of prostitution" of the sovereign power of the commonwealth, is by no means exaggerated. Federal Judge Landis in a similar case summed up the matter not inaptly, when sentencing a broker to ten years' imprisonment for fraudulent promotion, "The state of Delaware would face indictment for licensing such corporations as the Pan Motor Company if I could summon a sovereign state into court."

The intensity of competition of state with state is peculiarly manifest in respect of the several novel practices which are shortly to be described somewhat more in detail. It is, bit by bit, from a timid proposal in a single venturesome state, that no-par stock has reached its present widespread acceptance; it is thus that the traditional right of shareholders to a prior participation in all new security issues has been, little by little, so grievously abridged; thus has it come about that the practice of legalizing new issues by a majority vote either of stock present or voting, or by a mere majority of the total number of shareholders, has crept in. The worst abuses of holding-company finance crept in, it may be, to get rid of an inconvenient accumulation of unpaid preferred dividends, or perhaps surreptitiously to appropriate an undisclosed surplus in some corporate treasury. Nor is there ever any security against the intrusion of some new kink at law. Virginia, perhaps, stands alone for the moment in the laxity of its statutes respecting liability of shareholders in the issue of new stock without par. Not only is there no par, but the mere issuance of a receipt of approval by the Corporations Commission operates to absolve the shares thus issued from any liability whatsoever subsequent thereto. 
There is a familiar story about the young man who was urged by his father to take a wife. The answer was, "Really you know, Father, I have n't the slightest objection in the world! But whose wife shall I take?" Such is the dilemma of the intending incorporator, confronted with the stock of attractive legal goods displayed upon the shelves of some of these merchandising states.

Much of this competition of state with state for corporate favor arises, of course, from the desire for public revenue. The income from fees and taxes is often very large. The state of New Jersey, in fact, was for many years able to subsist without much, if any, income from direct taxes upon private citizens or their property. At the present time, for states like Maryland or Wisconsin, an income approximating a quarter of a million dollars annually is obviously a matter of some importance. The fees and bonuses for a large state like Pennsylvania may constitute a substantial part of the total state revenue.

The general situation was well described by Federal Trade Commissioner Myers before the American Academy of Political Science in 1926 as follows:-

Public opinion will not long tolerate a condition under which a few states vie with one another in creating corporations with unlimited capital and powers, without requirement that they engage in business in the states of their incorporation, and without provisions looking to the disclosure of their operations or accounts, to transact business and market their securities in other states. An effort has been made to justify these loose incorporation laws on the ground that they encourage the development of industry within the states; but the effort fails in view of the omission of any provision that the corporations shall conduct their operations in whole or in part within the states of their incorporation. The inference is irresistible that 
the incorporation of companies is solicited by these states because of the license fees and other revenue derived from the business. The creation of corporations has lost its dignity as an exercise of the sovereign prerogative for the furtherance of commerce and in the interest of the people of the state. What was once regarded as the conferring of a great privilege, to be limited and circumscribed by all necessary provisions for the protection of the public, has become a bargain sale, and states are advertising and competing for the business.

But it is the evidence of an unholy alliance between private profit and the exercise of this supposedly sovereign function which is at times the most debasing in its influence. The system tends to create a horde of shysters, ready to perpetrate any sort of corporate enormity, provided only that the fees are sufficiently ample. And attorneys, on their part, as one of them writes me, "pick their states of incorporation as you or I would pick out a department store at which to trade."

Another shameful angle to this business is that it tends to envelop our state legislative chambers in a noisome atmosphere of political honeyfugling, if not of downright corruption. A minor modification of a state statute may be worth large sums of money, because of its effect either upon plans in contemplation, or else as affording possible relief from the untoward results of acts already committed. And just because these amendments are seemingly so insignificant, they may be slipped through without arousing comment and perhaps almost entirely without notice. The temptation to spend money in what amounts to bribery, in order to attain such results, may upon occasion be very great. Nor need the immediate accountability for such corruption necessarily rest upon the corporations themselves. The system gives rise to a considerable body of irresponsible 
intermediaries - henchmen, lobbyists if you please specialists in such branches of the law, hangers-on about the state capital. The great corporation merely whispers its need. Subservient agents hasten to bring about the desired result, and perhaps no questions are asked. Such were the corrupting influences in the old days of the railroads and of the liquor interests. Both of these are now happily nonexistent; the railroads withdrawn from politics for good, and the liquor interests having transferred their activities to the larger domain of political propaganda in general. Protective tariffs are still with us. And there yet remains in and about these legislative halls a murky atmosphere which is necessarily attendant upon corporate influence. In order to be specific, however, concrete illustrations are d̀ propos. The New Jersey Act of March 28, 1902, which made provision for the so-called Steel Corporation Bond Conversion, was a piece of special legislation serviceable only for the commission of a proposed act. At Trenton also there was slipped through in the following year the notorious amendment of the New Jersey corporate code intended to relieve the directors of the American Malting Company from liability for the declaration of unearned dividends. This amendment was passed on the last day of the session by a bare majority of two votes in the House and one in the Senate. But it surreptitiously sought to vitiate the existing law by providing that directors should be liable to stockholders only in cases of willful or negligent violation of the statute. To be sure, the matter was finally settled out of court by the repayment of $\$ 340,000$ in cash, and the restoration of $\$ 1,000,000$ in common stock of the corporation. The statute apparently failed of its purpose; but the scandal of its enactment was not 
in the least lessened thereby. One might in the field of railroading adduce the further instance of the New York Act in 1900, so amending the law as just barely to admit the Harriman issue of Chicago and Alton bonds to the list of legal investments for savings banks.

So much for the stage setting. Now for the corporate actors. The next step in our analysis has to do with recent tendencies as revealed by the articles of association of some of our newer corporations. Obviously, however, they are not to be taken as typical of the mass. Rather are they samples selected more or less at random from the heap, although presumably because they are somewhat more brilliantly colored than the average. Their significance lies in the revelation of possibilities for the future, and particularly because for the most part they illustrate the steady encroachment of management upon the traditional rights of shareholders. Never mind if, as will doubtless be alleged, these novel charter provisions at law merely seem to be intended to bring the law into accord with existing facts. If the facts are wrong, it is then high time that we set about changing them. It is quite evident that an onslaught of such considerable proportions in the aggregate has already taken place as to call for serious consideration. Among these recent tendencies, the following are particularly to be noted: the limitation upon the right of shareholders to participate in future issues of securities; sole responsibility arrogated by management to issue new securities, if necessary having priority over those already existing; practically unrestrained authorization of managements to dispose of new shares upon any terms which they may think fit; power to sell the assets or to enter into new 
corporate relationships without let or hindrance; and, to complete the picture, an attempted exemption from liability on the part of directors and officers for results which may flow from a proprietary interest adverse to that of the corporation. These are the provisions which, taken as a whole, clear the ground for, and are now especially contributory to, the primary issue to be considered in the next chapter, namely the abrogation of the voting rights of shareholders, not alone in respect of these, but perhaps of all other matters appertaining to management and profit.

The right of shareholders in a corporation to participate to their advantage in all subsequent issues of shares by the company in which they have an investment has become traditional. It is of the very essence of corporate democracy that all members of the company shall stand upon an even footing one with another. Out of the exercise of this right has developed the modern practice of making provision for new capital by issues of stock at such a figure below the market price as shall yield a bonus to those who participate. This situation creates what are popularly known as stockholders' "rights." 1 They amount oftentimes to a substantial addition to the income of the shareholders in the case of prosperous concerns. The legal name for the advantage is that it is a preëmptive right - a right, that is to say, to a first opportunity to buy new securities before that offer is extended to the general public. This preëmptive right is almost as old as the privilege of limited liability, neither of them originating with the corporation but having developed out of experience with it as a convenient means for the

1 For details of such transactions consult Ripley, Railroads: Finance and Organization, p. 267 et seq. 
attainment of certain objects. The objective of the preemptive right is, of course, the provision of new capital by subscriptions drawn primarily from the partners in the enterprise, without disturbance of the existing ratios of investment and control. This traditional preëmptive right has been of late put in serious jeopardy by a quite general practice which seems to have begun after I9I9. At first it was embodied in new articles of association, merely as a matter of private contract. But it speedily developed into formal amendment of the corporation laws of Delaware, Maryland, and New Jersey dealing with the powers of boards of directors. The seriousness of the inroad upon the shareholder's rights has been but little appreciated by the world at large. So far has the movement progressed that even Massachusetts, one of the normally conservative states, had to come to it in 1920. The statutes themselves are ordinarily brief, providing perhaps merely that "such increased stock may in whole or in part be disposed of without being offered to the shareholder." The form which this innovation assumes in the charter itself is usually more elaborate, running something like this:-

No holders of stock of the corporation, of whatever class, shall have any preferential or other right of subscription to any shares of stock of any class, or any securities convertible into shares of the stock of the corporation; nor any right of subscription to any thereof, other than such, if any, as the board of directors in its discretion may determine, and at such price as the board of directors may fix; and any shares or convertible securities which the board of directors may determine to offer for subscription to holders of stock may, as said board of directors shall determine, be offered to holders of any class or classes of stock at the time existing to the exclusion of holders of any or all other classes at the time existing. 
- Details vary, of coursel. Great Atlantic and Pacific Tea Company (Maryland), or National Dairy Products Company (Delaware), may be content merely to put an end to this right for preferred shareholders only $\mathrm{Pan}-$ American Western Petroleum (Delaware) may limit the right upon approval by three fourths of the board of directors. Or, as in the case of General Baking Corporation (Maryland) or of the Standard Oil Company of California (De aware), not only have the stockholders no right to subscribe to additional shares of any class, but the board of directors can authorize the issue of new shares of any class, unlimited on account of the absence of par value and irrespective of any priority which there may be in the then existing nonvoting /stock. Entirely: similar disabilities are found among the recent charters of public utility companies, 2 Eastern States Power Cor poration (Maryland), Central and Southwest Utilities and International Power (Delaware), and National Electric Power (Maine), fór example.

"The argument in favor of this serious trespass upon the customary right of shareholders to a pro-rata subscription to all new issues of capital stock is a purely practical one. It originates naturally enough among the corporation lawyers, speaking on behalf of the banking, promoting, and management interests. This argument is in substance that corporations must of necessity, when committing themselves to a considerable program of construction or development, have assurance that the necessary funds therefor shall be presently available. The difficulty in practice is that the shareholders as a whole at best move slowly, and may never be positively depended upon to come forward with the necessary subscriptions. For shareholder bodies are sometimes fickle, 
affected by the general outlook, or, in particular, by rates for money and the competition of other investments. The actual yield of the new offering, therefore, it is alleged, may not be ascertained with certainty in advance. Under such circumstances there may have to be an underwriting of the proposed issue by outside bankers, which engage to take up all of the subscriptions which are not otherwise absorbed. This obligation, it is said, the bankers are loath to assume, first, because they do not know how large the balance unsubscribed may be; and, secondly, because the extent of this commitment may not be known for a considerable period - the time which is necessary in order to determine the shareholders' will. Because market conditions may materially change during the interval, the bankers are unwilling to shoulder an indeterminate risk without a considerably enhanced charge for the service. Sometimes, of course, this expense for underwriting, as in the case of acquisition of new property, may be avoided by issuing the stock directly in exchange therefor. Shareholders would naturally have no preëmptive right under such circumstances. But in case of a prolonged construction program this plan is not feasible. Sometimes where there is a concentrated share ownership, the reluctance of the bankers is abated by the ease with which the general prospect may be foreseen after consultation with the dominant stockholders. But in many other cases, it is alleged, the provision of new funds by general shareholder subscription is apt to be slow, cumbersome, and expensive. And with thousands of very small stockholders, as under the modern development of customer ownership of public utilities, all such operations seem to be practically impossible. The fact, however, that the shareholder's interest in this matter is 
entirely eliminated without adequate compensation by the new device seems hardly to have been considered seriously by those who defend the innovation. The principal reason for concern in connection with it is due to the increasing complexity of the corporate structure nowadays. With the old simple financial set-ups, it is conceivable that internal tension between different classes of shareholders would not arise. But it is because of the extraordinary involution of corporate structure and also of the increasing interplay of corporations with each other that one may seriously question whether this abolition of the preemptive right is a move in the right direction. It certainly is not, unless more carefully circumscribed than it appears to be at the present moment.

It seems to be clear, therefore, that the defense of the customary right of shareholders to participate on the basis of their holdings in all of the "juicy fruits," as one correspondent puts it, of new security issues, has never been more convincing than at this moment. Never has the danger been so great of an insidious undermining of the rights of the ill-represented main body of shareholders, by reason of the introduction of a number of new clauses in the charters of our corporations, great and small. At common law, the doctrine that the shareholder is entitled to maintain his full existing proportion of the stock of the company under all circumstances is derived from the fact that his relative voting power in the corporation will otherwise be diluted in the event of an issuance of more new shares. A second defense is that the shareholder, entitled by reason of his investment to a certain fraction of the company's earning power, will be subjected to a similar dilution of his right to participate in these earnings. It is argued that for modern large corporations 
these defenses have ceased to have validity, inasmuch as the shareholder who wishes to maintain his existing proportionate interest, either in voting power or as to earnings, may always have an open market in which he may buy enough new shares to bring up his proportion to its original figures. But this fails to meet the objection that if a considerable number of shareholders were thus compelled to go into the public market to buy enough shares to maintain their proportionate interest, they would probably have to pay an excessive price - a price at all events greater than would attach to the exercise of their preëmptive right. In other words, the shareholder would be exposed to the danger of having part of his joint possession sold to others for an inadequate consideration. And this danger is a particularly imminent one, where, as we shall soon see, the management seeks to entrench itself legally by exemption from recovery of damages by the shareholder body. In any event, the invention of the no-par common stock, coupled with the various devices for disfranchising various groups of shareholders, especially as respects new issues of securities with special priorities, renders it a matter of prime importance that further abridgment of this customary right should be most critically reviewed.

The various other licenses created under present-day chartering practice, enabling managements to function in practical independence of the shareholding body, have already been enumerated. General Baking Corporation (Maryland, 1925) may be taken as a fair individual sample thereof. The corner stone is the issuance of no-par stock, not only the common shares, but in this instance the preferred shares as well. The stockholder's preëmptive right to subscribe to additional shares of any class is 
abrogated. The voting shares may create any class of stock equal to or prior to the preferred shares. The directors can authorize the issue of shares of any class for any consideration, unlimited, of course, in this case on account of the absence of par value. The only moderation manifested seems to be in imposing some slight restraint upon the power of the directors to dispose of the assets of the corporation.

The foregoing provisions are of course extreme. But I have in mind the principal organization papers of another corporation which goes a step further toward the ultimate. For its Maryland charter also specifically disposes of any requirement "to accumulate any reserve or otherwise provide in advance for the payment of any sum to the holders of preference stock on liquidation, dissolution, or winding-up." Another section is so drawn as apparently to permit the board of directors to receive money or other property, credit any part of it to reserve or surplus regardless of whether it is in fact income or capital, and thereafter to distribute it without reservation as dividends or to charge off losses against it. Another permits the sale, lease, or exchange of all of the property and franchises without limitation as to terms, by a majority approval of the common stock voting shares "with or without a meeting or by vote at a meeting called for that purpose." Another section permits reincorporation or reorganization, coupled with the conveyance of all the assets to a new corporation. It will be said that the means authorized, namely by writing or proxy without a meeting, is the manner in which such things are usually brought to pass. But it is the sum total of these provisions, taken in connection with the one subsequently to be considered concerning relief from liability for directors 
on account of an adverse interest, which makes this particular charter the veritable consummation of a highly iniquitous tendency. The capsheal perhaps of this attempted arrogation of supreme power recites that in the event of the transfer of sthe assets: as an entirety to a new corporation, "each holder of stock in the Corporation lagrees for thwith to surrender for cancellation $/$ his certificate or certificates for stock of the Córporation, and to receive and accept in exchange therefor, as his full and final distributive share of the proceeds of such sale and conveyance at a number of shares of the stock of the new company Such new company may, but need not, have all or any of the powers of the Corporation and the charter and by-laws of / such new company may; but need not, contain all or any of the provisions contained in the charter and by-laws of the Corporation:" And all this, quite regardless of the fact that no court in its right senses this dictum, by the way, from one who is no lawyer would ever regard such a dragnet proviso as sustainable! The remarkable thing is that good lawyers should pander to the inordinate ambition of financiers by affixing their names as drafting counsel to such a document. It is difficult to conceive of another set of charter provisions, articles; iand iby laws that go to lsuch an extraordinary extent as do these in conferring arbitrary, and absolutely uncontrolléd power upon an inside group: InIllustrations abound of similar exceedingly broad grants of power to boards of directors for public utilities. Under the Delaware charter of North American Light and Power Corporation it lies within the sole discretion of the management, represented by vote of the common stock only, to sell out all of the assets of the corporation. The same thing is true of the Interstate Power Company and of 


\section{6 \\ MAIN STREET AND WALL STREET}

the National Electric Power Company, except that in the latter case the consent only of the Class B voting common stock is requisite. All of the preferred shareholders and of the nonvoting common shareholders are completely disfranchised so far as this vital matter is concerned.

An egregious malversation of the rights of shareholders and of the public generally is entailed in the device of so-called no-par capital stock. This expedient is handmaiden to a considerable shifty company in contributing to corporate obscuration and even to fraud. Without no-par stock some of the other innovations in corporate practice would lose much of their poignancy. By its aid a number of different elements contributory to a conspiracy against the interest of investors and of the public are welded together to form a substantial menace to sound corporate finance.

Ever since the introduction of limited liability which, by the way, is not a congenital but only an acquired characteristic of corporations, the principle, in brief, which relieves the shareholder in an enterprise from any liability to his corporation beyond the amount of the actual investment - it has been customary to limit and define this liability by the imprint upon each share of stock of a stated par value. So universal was the practice that no one seems to have dreamed of its modification. And then about 1909 a committee of eminent attorneys, headed by Francis Lynde Stetson, persuaded the New York Bar Association to endorse the novel proposal to issue stock "without the dollar mark" - in other words, to represent it merely as "a certain aliquot part" of the net value of the enterprise. It would lead one astray to discuss whether or not this proposal stood 
in any definite relation to clearing up the wreckage created by the scandalous looting of the New York City Traction properties. That it proved serviceable in that connection in affording relief from troublesome litigation seems quite probable. The proposal had hard sledding at first. Passed by the New York Legislature, it was at first vetoed; and then in I9I 2 it was reënacted, to become law. Thereafter matters took the usual course. Maryland followed suit in I9I6. The next year California, Delaware, and Maine fell into line. By this time the landslide was in full motion. Virginia came next, followed in I9I9 by Illinois, New Hampshire, Pennsylvania, and Ohio; until well-nigh forty states in the Union now permit the formation of corporations with shares of stock stripped of a stated par value. Adoption by business men has followed close upon the heels of statutory authorization; until at the present time, for common shares at least, no-par stock has become the rule rather than the exception, for public utilities as well as business concerns. The next step was the spread of authorization for the issuance of preferred shares without par value, this by Maryland in I924. Delaware of course had to follow suit the next year or stand to lose business heavily. And so the matter goes. It is but the old, old story over again, traversing the same course of development; and with practically the same states falling into line in the same order.

The reason for the original assertion of a par value was that it measured supposedly the capital which the shareholders had agreed to contribute to the enterprise. ${ }^{1}$

1 Two most illuminating papers are: on the economic side, 2uarterly Fournal of Economics, May 1924, and Columbia Law Review, May 1924, by Professor J. C. Bonbright; and, more technically at law, Columbia Law Review, January I925, by A. A. Berle, Jr. 
Limited Mability being sthe outstanding characteristic of the corporation, creditors were deserving of information as ito theladequacy be thie assets for satisfaction of theif claims. TThus the tcorponta tion enbarked supon its career with burcertain Istatedq investment, din theorye at least. And creditors supposedly enjoyed two Iremedies; first, that stockholders, had they inøtrpaid in the full par, might be held personalty liablet for the balanee; and, secondly, that directors might bedheld liable for anyo impairment of the dapital ifund byls the declaration of unearned dividends. siSo nuch for the theory! ?As to the fadtsy score of ways weren invented for eovasion tof theser diabilities. Shares might be rissued rith sgreat excesis in lexchange for property or for servicess itendered, which owere absurdly overvalued, sthis being perhapss the csimplest and most dired means of evasion? BThaslit turhedrout that stock watering + perhaps thes niost nuviversallyf saccepted of

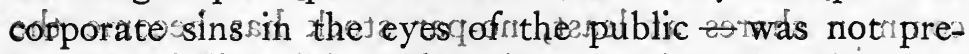

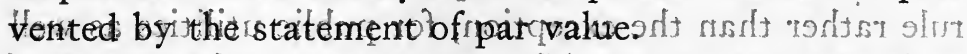
to But therel was downright inconvenience attaching to the ruse of pare value ts This was that it subsequently prevented twhat has (well been icalled " Ifféxitole irefinancing:" For it was (universalicstatutory rule that, having once established at parivalluezfor capital shares, bany issuance thereafter of mope shares at less than thisi figure was unlaw ful the theason, nof course, sbeing that th tended to dilute the worth of the securities ffirst putsout at the higher figure! s Sonthatedrefritioo, sdorporations found themsetves rembarrassed wher linaneed of further capital; being unables to raise mbineys needed for development, in the event that the market price of the, outstanding issues happened to be selling for tess than $\$ 100$, or what ever the stated par might be. 
The entire campaign supporting the introduction of the new device of no-par stock consisted of presentation of its advantages, particularly the fact that the removal of the stated par value would permit new capital to be raised under all circumstances wherever existing market quotations might stand. And it was added, furthermore, that this possibility of financing by new stock issues tended equally to discourage the more dangerous resort to borrowings by the issue of bonds or short-time notes. All told, the device was appealing; it facilitated promotion, doing away with the disagreeable necessity of a contribution of stated amounts of money or of property; it loosened things up generally, and to that degree won its way to public acceptance. It was urged also that it tended to protect the investor against being deceived by false appearances. He was to contemplate a share of stock, not somehow as having inherently any definite value but as merely representing a fractional interest in the earnings and assets of the company. Thus - only vastly more in detail - were the advantages set forth. Some of us were skeptical from the start, perhaps overmuch so. ${ }^{1}$ But since that time, as the wedge has little by little been driven home, it has become clear that the device is overflowing with possibilities of fraud and deception. All solid bench marks from which a financial history of any given enterprise may set forth are abolished, leaving in place thereof but constantly shifting sands. The possibilities of deception were perhaps never better exemplified than in the collapse of a promoter's dream in the failure of National Conduit and Cable in 1917. A long series of excesses in promotion, with escape from the liability which ought to attach thereto, is embodied in the

${ }^{1}$ Ripley, Railroads: Finance and Organization, I9I5, p. 91. 
records of our courts. The accountants are enabled to play ball with figures to an astounding degree. Our example from Dodge Brothers, Incorporated, on page 199 shows what may be done with so-called surplus. Another case, that of Di Georgio Fruit Corporation on page 196, demonstrates how readily true facts as to earnings may be concealed. Worst of all, as a menace to the public interest, is the issue of no-par shares in the field of public utilities. It is unquestionable that the scandalous stock watering which has placed the voting control of more than $\$ 1,500,000,000$ of funds of the general public invested in public utilities in the hands of the common stockholders, who paid not a cent for their holdings, is directly traceable to misuse of this device. ${ }^{1}$

But, like most things on earth, human beings particularly, no-par stock is not altogether bad. It embodies a useful principle. It is indubitable that it affords relief from an undue inflexibility of financial set-up. Held within proper limits, it may confer this advantage, and yet be safeguarded against some of the evils which have just been set forth. The remedy is discoverable in the distinction between the laws on the subject in the two states of New York and California, and those of the two score or more other states which have legislated upon the subject. The state of New York having seen the light in I923 put its house partially in order in this respect. It provided that whenever capital was represented by no-par shares that such stock nevertheless might have a stated value, that is to say that so and so many dollars of capital should be represented definitely by so and so many units of no-par capital stock. To be sure, New York still permitted true no-par shares to be emitted - shares, that is

1 Cf. pp. 325 et seq. 
to say, which were not tagged with any fixed par value at issue. And for all of this second sort of no-par stock, the objections stated above as to let and license hold good. But as to the former sort the value of the consideration against which each piece of paper is put forth must be explicitly stated. For such stock there is a restoration of that old solid foundation which once prevailed for use of the accountants in starting their records. And the same thing is true for the lawyers, in their legitimate interest in protecting the public, by the assignment of a definite liability for a capital fund on the part of the promoters and the management. The corporation, however, while still required to start with a certain capital fund, is in position to raise whatever additional capital is needed for growth. It may do this by the issuance of new shares at a stated figure but not necessarily the same as in the original forthputting. The first issue might be at $\$ 100$ per share, another at $\$ 33$, and a third at $\$ 133$. But always there should be a stated issue price, bringing to the corporate treasury that amount of new assets. Thus would "flexible refinancing" become a matter of fact and of record. This, then, is what ought to be done to clean up the situation. ${ }^{1}$ New York and California ought to close out the present option which permits the issuance of true no-par stock. They should legitimatize only an issue with a stated par, permitting each lot, however, to stand upon

1 A section of the just proposed corporate code of Ohio, presented by a special committee of the State Bar Association, allows stock to be issued without par value:-

$\S$ I3 (b) At any time or from time to time after organization, for such amount of consideration for each share (which amount shall be equal in respect of all the shares of the same class authorized to be issued at the same time) as may be fixed by the affirmative vote of the holders of a majority of the outstanding shares of the class to be issued, and like vote of the holders of shares of each class junior thereto (regardless of limitations or restrictions on the voting power of any such classes) or by the board of directors when authorized by a like vote of the shareholders or by the articles. 
its own feet as respects the issue price. And the thirty or forty other states in the Union ought in the public interest to bring about the same result. For in so far as they fail to require a stated figure somewhere for each capital issue, the door hangs wide open for all sorts of financial jugglery. Nor, of course, can it be closed by the adoption of sound legislation by any two states, so long as the forty-odd others prefer for profit to pursue another course. Thus again are we brought face to face with this fundamental obstacle inherent in our governmental system.

There is a peculiar menace in the setting-off of a socalled initial surplus upon the creation of a corporation. This will be further developed in our chapter upon corporate publicity. But it should be noted in passing that the institution of no-par stock considerably widens the opportunity for resort to this unsafe distinction. The object of course of setting off at the outset a part of the capital contributed to form a corporation as initial surplus was to create the outward appearance of a fund distributable as dividends. The practice of stimulating markets by initiation of dividends upon small issues of preferred shares is a long-standing one. The United States Steel Corporation, long before no-par stock was invented, started upon its career with a purely fictitious surplus of this kind amounting to $\$ 25,000,000$. The misuse of the device in prospectuses which, among other things, mention the expectancy of shortly putting the new issue upon a dividend basis is nowadays frowned upon in conservative circles. No-par stock distinctly tends to enhance the danger of misrepresentation.

It has already been averred that no-par shares dovetail into all of the other iniquitous novelties at law which 
have been described a to constitute the groundwork for the culminating offense of alt, disfranchisementr of the pirblic shareholder. In passing it may be well to drive this assertion home. AIs it not obvious that the absolute and uncontrolled power afforded by theser new charters to fix the price of each newilissue ibf shares, independently of all the others, reduces the whole matter, as Berle puts it, "to the merest gamble on/ the integrity and judgment of the corporiate Qfficeris and direetors:ő Granted that these powers may hot ber so complete, actually as the statutorys language $\mathrm{indicates}$, neyertheless proceedings in equity to correct a wrong once committed are wearisome, expensive, and time consuming. And there may be a limit to patience as well as to the resources of those who otherwise might have the courage to fight for their rights. For they must personally finance their campaigns, whereas the management is always in position to draw upon the corporate treasury. Again, is it not clear that all sorts of conflicts between different classes of shareholders in these complicated set-ups are certain to arise, enormously confused by rights of conversion of par into no-par, or no-par into par, back and forth every which way? Most of all is it not clear that this no-par device is utterly unsuited to all public-service companies wherein by all the principles of sound regulation the issue of securities ought not to exceed the actual amount of the investment? This must be true, for, were it otherwise, there would be permitted the issuance of shares to represent goodwill, that is, shares which cost nothing but which merely represent capitalized earning power. It is a cardinal principle of sound public regulation that such capitalization of goodwill should not be. And inasmuch as the issuance of no-par shares cuts the ground from 


\section{MAIN STREET AND WALL STREET}

under any attempt to correlate closely the amount of the investment and a stated par value for the securities, it is clear that regulation and no-par shares are utterly incompatible one with another. A convincing demonstration of the difference between a no-par and a par value situation for public utilities is afforded by the recent financing of the Conowingo dam. ${ }^{1}$ Most regrettable must it ever be that so much of the financing of our great public holding companies, as it will appear in the chapter on the subject, has been consummated without the healthful restraint which was imposed in this instance.

1 Outlined on p. 325 et seq. 


\section{III \\ GETTING OUT FROM UNDER \\ VARIOUS ANGLES OF IT}

Insult added to injury, is the comment which instinctively springs to the lips upon examination of another set of legal innovations. For these, after concentrating all power and responsibility in directorates, seek baldly to hold them utterly scatheless as respects any liability at law. To be sure, running back historically, one discovers an occasional attempt to relieve directors by charter provisions, that is to say by private stipulation, from liability for profits arising from contracts in which they individually may have a peculiar interest on the side. Cases even are reported on such points as early as 1870 . They are discussed in law texts early in this twentieth century. They are said to have been uncovered in the Hughes-Armstrong insurance investigation in New York in I9IO. The idea is not new therefore. But it has been elaborated during the last four or five years, both by insertion as a mere contractual provision, and now also apparently upon statutory authority. It is quite evidently an outgrowth of the extraordinarily involved corporate relationships which have become characteristic of present-day finance. Especially is it an attribute of the intricacies of the corporate structures of our public utilities. It is from this last circumstance that the tendency derives a peculiar and a double significance.

Here are a few samples. Pan-American Petroleum 
and Transport (Delaware) charter contains this proviso: "Any member of the Board of Directors shall be at liberty to act as vendor in conveying to the corporation securities or other property ... or may enter into or become interested in any lawful contract or agreement with the corporation. And no such sale, purchase, transaction, or agreement shall be void or voidable by reason of any direct or indirect personal interest of any director therein." Studebaker Corporation's charter from New Jersey likewise relieves directors "from any liability that might otherwise exist from contracting with the company for the benefit of himself or any firm, association, or corporation in which he may be in any wise interested." So likewise United States Cigar Stores Company (New Jersey), or Safe Way Stores (Maryland). Then there is a considerable number of charters which protect the management against such liability under certain circumstances - circumstances, it may be said, which conform to good, sportsmanlike conduct as between straightforward individuals. The Great Atlantic and Pacific Tea Company affords relief from liability "provided that at the meeting of the Board or of the Committee authorizing or confirming such contract or transaction, there shall be present a quorum of directors not so interested or connected, and that such contract or transaction shall be approved by a majority of such quorum, which majority shall consist of directors not so interested or connected." General Baking Corporation (Maryland) adds the further proviso that such interest shall be "disclosed or made known," while National Dairy Products Company (Delaware) requires even that such interest shall be "fully disclosed." Standard Oil Company of California (Delaware) permits the interested director or officer after such disclosure to 
count in determination of a quorum as well as to vote; but Ward Food Products Corporation (Maryland) couples all of these up, in the requirement of disclosure and disqualification for voting, although permitting the name to count in determination of a quorum. An admirable instance of a carefully drawn charter provision on this point reads as follows [the italics being our own]:-

A director of this Corporation shall not, in the absence of fraud, be disqualified by his office from dealing or contracting with the Corporation, either as a vendor, purchaser, or otherwise, nor in the absence of fraud shall any transaction or contract of this Corporation be void or voidable or affected by reason of the fact that any director, or any firm of which any director is a member, or any corporation of which any director is a member, or any corporation of which any director is an officer, director, or stockholder, is in any way interested in such transaction or contract; provided that at the meeting of the Board of Directors or of a committee thereof having authority in the premises to authorize or confirm said contract or transaction, the interest of such director, firm, or corporation is disclosed or made known, and there shall be present a quorum of the Board of Directors or of the directors constituting such committee, and such contract or transaction shall be approved by a majority of such quorum, which majority shall consist of directors not so interested or connected. Nor shall any director be liable to account to the Corporation for any profit realized by him from or through any such transaction or contract of this Corporation, ratified or approved as aforesaid, by reason of the fact that he or any firm of which he is a member, or any corporation of which he is a stockholder, director, or officer, was interested in such transaction or contract. Directors so interested may be counted when present at meetings of the Board of Directors or of such committee for the purpose of determining the existence of a quorum. Any contract, transaction, or act of this Corporation or of the Board of Directors or of any committee which shall be ratified by a majority in interest of a quorum of the stockholders having voting power, 
shall be as valid and as binding as though ratified by every stockholder of the Corporation.

The opposite extreme, seeking to afford unqualified relief from directorial liability under all circumstances is found in the certificate of incorporation from New Jersey of the Pennsylvania-Dixie Cement Corporation. This instrument provides that no contract or transaction in which any director or officer may have an interest adverse to this company shall be invalidated or in any wise affected by that fact, "even though the vote of such director might have been necessary to obligate the corporation upon such contract or transaction, and even though the fact of such interest was not disclosed to other directors or stockholders of the corporation acting upon or with reference to such contract or transaction. No director having such adverse interest shall be liable to the corporation or to any stockholder thereof, or to any other person, for any loss which may be incurred by the corporation ... a and no such director shall be accountable for any gains or profits realized therefrom." This from New Jersey, if you please; but Maryland promptly proceeds to flatter the practice by direct imitation, and to go it one better in the case of other companies chartered thereafter. The most disconcerting feature about these latest developments is, of course, the evident intent to seal up transactions of the sort against disclosure. This dastardly feature is entirely novel.

But these extraordinary exemptions from liability in the case of purely private industrial concerns are, if anything, overmatched by the license accorded to management within the last few years in the field of public utilities. A few examples from the pile of charters on 
my desk may be cited. Interstate Power Company (Delaware), Eastern States Power Corporation (Maryland), and American Light and Traction Corporation (Delaware) permit voting upon any contract or other transaction without regard to the fact that directors may have an adverse interest therein. National Electric Power Company (Maine) decently enough requires that such a transaction shall be ratified by a majority of a quorum of uninterested directors. Some companies, North American Light and Power Corporation, and Associated Telephone Utilities Company (both of Delaware), have no clauses on the point; but Central and Southwest Utilities Company is authorized by the same state to purchase or acquire, and so forth, all kinds of property from any person or corporation "who may be or are deemed to be, as to this corporation, a promoter, an officer, or a director"; " and each stockholder of this corporation shall be deemed, by reason of his having become such, to have waived any and all objections to such acquisition .... and to have agreed that no promoter, officer, or director shall be liable to account to this corporation for any profit or benefit derived by him by reason of such transaction." There's a good sample for you of what these chartermongering devices are foisting upon the American people. Never mind if the courts shall ride roughshod over such legal flummery! The scandal inheres that the good name and the sovereign power of an American state should be so debased for private gain.

The natural and normal object of the foregoing provisos is, of course, to meet the contingency pointedly described in the certificate of incorporation of the American Light and Traction Company (Delaware). "Inasmuch as it is expected that the directors of this corporation 
will be men of large and diversified business interests, and may be connected with other corporations with which from time to time this corporation may have business dealings, no contract or other transaction ... shall be affected by the fact that a director of this corporation is ... otherwise interested in such other corporation." But there is another way, more insidious yet more direct, in which a person may be virtually called upon as a trustee to vote upon a matter in which he may personally have an adverse interest. Such situations in complicated modern business may be expressly created in fact by the management which bears the responsibility.

The objection to an undue limitation upon the right of directors to work their will in management, regardless of a possible conflict of interest, is of course that inextricable confusion would result were the courts to undertake the reading of the minds of voters as respects their leading motives. ${ }^{1}$ The law has always held that all contracts between a corporation and a director, whether void or not, are always voidable. And it has been held furthermore that the right of avoidance is vested in the shareholders. The doctrines vary from state to state, setting up different degrees of invalidity. But all of these doctrines unite in recognition of the right of the corporation to upset the transaction if it be in any way prejudiced. And what is true of directors is applicable also to dominant stockholders. It may well be that a majority shareholder may expose himself to liability by jamming through a transaction in his own interest, but at the expense of the corporation as a whole. Liabilities sometimes may, therefore, run back of management to

1 This matter is ably discussed with copious citations of cases by A. A. Berle, Jr., Harvard Law Review, April I926. 
the real source of power, as was well said in a leading case by Chief Justice Taft, then Circuit Judge: "The vice of such contracts is . . . that they are contracts made by a corporation with one who exercises such an undue influence over the directors by reason of his relation to them as principai stockholder or otherwise, that it is inequitable or unconscionable for him by such influence to secure individual profit to himself at the expense of the corporation and its other stockholders and bondholders." Is it not evident, then, that a state of the law in this regard has at last supervened, which merits a rigorous reëxamination? That is how it looks, as viewed from the outside.

It is now possible to revert to a more general view of the conditions which this book has been discussing. Several attributes of this thing which we call a corporation are roughly embodied in certain well-known historic quotations. These may be conveniently taken from times a hundred years or more apart. Old Coke - Sir James, that is - early in the seventeenth century, under good King James the First, has this to say: "As touching corporations, the opinion of Manwood, Chief Baron, was this: that they were invisible, immortal, having no conscience or soul - and therefore no subpœna lieth against them; they cannot speak nor appear in person, but by attorney." This definition lays emphasis upon the fact that the corporation is an entirely artificial creature of the law. Along about 1765 comes Sir William Blackstone, another legal worthy of accepted standing. It is his view that the corporation is "an artificial person, created for the preserving in perpetual succession certain rights, which if conferred on natural persons only, would fail in 
the process of time." Herein is embodied the idea of perpetual existence, immortality, the possible succession of membership without change of identity; and along with it, of the possession of privileges derived from some supreme source of power. It may repay us to consider these characteristics in the light of the existing situation.

As to immortality, the powers enjoyed by corporations being in the nature of an express grant from a sovereign state, it would appear as if the time element, the length of the license, were of primary importance. Yet it is for the most part entirely ignored. Most charters in America are made in perpetuity, quite regardless of the direct interest which the people might have in a periodic review of their serviceability. Even if a concern ceases to do business, in the eyes of the law it continues to exist forever. Since the charter is held to be in the nature of a contract, it is not one to be forfeited without the consent of the state. Yet how many formal surrenders of these thousands of charters do we witness? Over in England they have a Commissioner on the Winding Up of Companies in the Board of Trade. During 1925, this official struck some 2500 companies from the rolls. But with us, instead of being put aside, these grants of power still stand always subject to revival; and possibly to be devoted to quite other uses than those for which they were originally intended. Just as our highways are cluttered up with old Ford cars, which,' had they been of any other make, would long since have been consigned to the scrap heap, so do these sovereign licenses persist beyond their natural span.

For a time the prosperity of antique dealers in Colonial furniture and like objects used to be well-nigh matched by a corresponding activity in merchandising antiques 
of the charter variety. Fabulous prices are paid for rare first editions of books, relics of the time of Aldus or Caxton. Undisclosed sums used also to be paid for some of these old corporate charters, discovered stowed away under the eaves among the letters and papers of a past generation. For this was a generation not too particular perhaps about specification in its grant of powers through act of the sovereign state. Whether our example be the Northern Securities Company, first great railroad monopoly to be condemned by the Supreme Court of the United States; the Temple Iron Company, an instrument for the creation of an anthracite coal monopoly; the New England Navigation Company, agency of the New Haven Railroad for tying up the shipping business of the north Atlantic seaboard; or the Associated Merchants' Company, legal means for the creation of the first great American department-store monopoly; it is always the grant of "power to conduct any lawful business" which is so invaluable for purposes of incorporation. But now, alas, times have changed. The handiwork of these old artificers is being driven out of the market by the standardized mass production of our regular corporation factories. Authorization is granted by some of the states to do anything. The fact that a corporation can, as the Wilmington Every Evening put it, protesting against a bill recently pending in the Delaware Legislature, "be empowered to do anything except commit murder or arson and other crimes," lies at the very root of a most serious situation.

The fiction handed down from the Middle Ages that a corporation is a legal person, entirely distinguishable from the personality of its members, was doubtless necessary and useful for purposes of reasoning and analysis. 
Such a concept is still embodied in Article 435 of the Civil Code of Louisiana, that "corporations are intelligent beings, different from and distinct from all the persons who compose them." The acknowledgment of this principle, however, without qualification may be provocative of grave abuse. Its inadequacy is most apparent to the lay mind in the case of failure to distinguish between the small and personal corporation and the large and publicly owned one. Take the one-man corporation as an instance, put before the world in a leading case decided by the British Law Lords in 1897 . A leather merchant, being in doubtful case, converted his business into a corporation. "Aron Solomon and Company, Limited," was duly registered under the Company's Act with himself, his wife, daughter, and four sons as shareholders and directors. Of the nominal capital of $£_{40,000}$, in one-pound shares, 20,00I were issued in the name of the patriarch. The family dutifully held six shares, one apiece, so as to qualify as directors. No other shares were put forth. Debentures, that is to say, notes, to the amount of £10,000 were then issued to Solomon as a first charge against the assets. The anticipated smash occurred; and the public creditors found their various claims preceded by these copious notes, much to their discomfiture. Query: was this refined creature at law soulful or soulless? And furthermore, was Aron Solomon and Company, Limited, identical with or distinguishable from the gentleman himself? The lower court of appeals held the entire arrangement to be fictitious and fraudulent. The House of Lords, on the other hand, concluded the matter by holding that, inasmuch as all legal formalities had been duly observed, there was no fraud. Fraud or no fraud, to the lay mind the whole 
flimsy pretext more than borders on the ridiculous. It rather controverts the famous characterization of Disraeli, that "the legal mind chiefly displayed itself in illustrating the obvious, explaining the evident, and expatiating on the commonplace."

Many other instances are available of the misuse of this familiar legal fiction. One of them occurs in connection with the common practice by which individuals sell a business together with its goodwill, along with an agreement not to reëngage in that same business thereafter. May they so reënter into competition, this time under the guise of a corporation? And may they successfully set up the defense that, as thus associated, they are not bound by any contracts into which they have previously entered as individuals? Or again, there is the familiar principle at law that no person may be compelled to testify in court against himself. If a corporation be not separable as to identity from the individuals which constitute it, it may not lawfully be confronted under litigation with demands made by shareholders. Or yet again, the whole matter of the liability of officers of a corporation for profits arising from speculation in its shares may turn upon the soundness of this principle. Insistence upon this view of a separable identity between the corporation and its members primarily arises from the fact that it is the main defense for limited liability - that attribute of the corporation which is most serviceable by way of contrast with a partnership. For no person in a partnership could be relieved from his share of liability for all debts contracted unless it were recognized that, by setting up the corporation, an entity clearly distinguishable from his own had been created by an act of law. Yet, while lying at the foundation of this most 
necessary and serviceable attribute, it by no means follows that for all other possible relationships the fiction of identity may be strictly maintained. The necessary distinction has been well stated thus: "A corporation will be looked upon as a legal entity as a general rule, and until sufficient reason to the contrary appears; but when the notion of legal entity is used to defeat public convenience, justify wrong, protect fraud, defend crime, the law will regard the corporation as an association of persons." "A corporation as expressive of legal rights and powers is no more fictitious and intangible than a man's right to his own home or his own liberty." (I 42 Fed. 247-255.)

The present need of frank recognition that for the small corporation there is no real distinction between the artificial and the natural persons has to do rather with matters of liability toward the public than of personal rights which may be possessed by the individual. To revert to the familiar example, the bundle of fagots may be in fact something distinguishable from the sticks which make it up. Yet if it be dropped upon another person, the impact in the aggregate is just as damaging if it consist of many units as if it were a solid log of the same weight instead. From a social point of view, it is the external relationships, not those within, which are of importance; and if it be true that the essential prerogative of man does not lie in rights but in duties, it will be equally true that the essence of juristic personality does not lie in the possession of right, but in subjection to liability. It is imperative, therefore, that this convenient fiction of corporate personality be amended and dovetailed into the facts of our common existence in all the complicated relations of modern life. 
To the layman it appears also as if a thoroughgoing reform were needed in corporate practice having to do with the competence of a corporation to act under the terms of its charter. A loophole of substantial proportions has been developed out of the possibility of claiming exemption from liability for an obligation by setting up in defense the plea of the inability of the corporation to enter into the engagement at all. Technically this has to do with what is known as the principle of ultra vires the principle, to repeat, that a corporation is an artificial creature of the law, having neither powers nor existence except for certain express purposes. From this it follows that if those express limitations be overpassed, the act of an officer of a corporation becomes in effect merely an act of an unauthorized and irresponsible individual. And such an individual, of course, may be difficult if not impossible to bring to book. Meantime the corporation goes scot-free. The opposite view, one which would seem to be deserving of far more emphasis than it receives at present, is that a corporation, once duly set up, is inherently endowed with all of those powers and capacities of a natural person which might conceivably appertain to so artificial a creature. According to this conception, then, the only defense of a corporation for untoward results of persons acting as its officers would be that they had disobeyed an express prohibition of the sovereign; in which event the corporation would be treated as indistinguishable from its personnel and either one or the other would become liable to the state, which acts always as a trustee of the common interest. In other words, the proper attitude of the state as to corporate discipline would under this conception be positive rather than negative. Engagements made outside the 
limits of charter activity would not be treated merely as void, but would be regarded as downright offenses, rendering some party, whichever it might be, liable to all of the penalties attaching thereto. Thus would the state be left clearly in position to punish the willful disregard of its several prohibitions, express or implied. Such a policy would tend materially to limit the area within which the defense of ultra vires could be maintained. It would tend to correct the present sanction under which the powers of the corporation are determined, not by the state acting as sovereign but by the incorporators who have a substantial self-interest in the matter. It would recognize the fact well stated as follows: "from being a mystic entity created by sovereign fiat, the corporation has at length become a form of organization for a group of individuals who are for all intents and purposes as much a freely acting body as is a partnership." And it would tend to stop the flow of litigation as great as it has been unprofitable, not to say ridiculous. Happily, the fact that individuals acting under the guise of a corporation should not thereby be freed from responsibility does not lack recognition; notably in the pending revision of the corporate code of the state of Ohio. Wholesome and much-needed restraint would arise, were these individuals still to be treated as a unit, but nevertheless as a unit substantially bound by the composite acts of the individuals. The group would be subject, in other words, to much the same liability as the individuals would have faced had they been acting in their several natural capacities. Stated in simple terms, the Ohio Special Committee on the Revision of the Corporation Laws of 1926 puts it thus: "Justice would seem to demand that a corporation should not be allowed to violate 
the principles of common honesty and claim exemption from its liability on an obligation by pleading its own inability to act." The proposed amendment to the corporate code will read thus: -

Subject to the rights of the state, no limitation of the exercise of the power or capacity of the corporation shall be asserted in any action between the corporation and any person, except by or on behalf of the corporation or the shareholders thereof, against a director or officer or person having actual notice of such limitation. The statement of purposes and any such limitations upon exercise of power or capacity shall be construed only to constitute an agreement by the directors and officers with the corporation and the shareholders that they will not cause the corporation to do any act not within such purposes or forbidden by such limitations.

The cardinal principle that not even the sovereign legislature of a state may grant powers by charter which are not fully in consonance with sound public policy has been consistently maintained by our courts at law. In other words, there are certain things in civilized communities which "simply are not done" - theoretically at least. One of these is indulgence in what in the English common law has come to be known as unfair trade practice. The dean of the New Jersey trust legislation, James B. Dill, many years ago sent me a copy of the charter granted in 1903 to the Cooley Epicycloidal Engine Development Company with the annotation, "some features which are worthy of examination ... but it is not stated that these provisions are to be in all respects followed." This corporation was authorized "to acquire, hold, and finally dispose of all that pertains, relates to, is necessary, advantageous, or desirable for the growth and development of Rotary Fluid Gears, Motors, Meters, and Pumps, and all business connected therewith . . . in 
any part of the world; ... to purchase and construct, operate and finally dispose of all moving vehicles, whether aërial, terrestrial, or marine, to which Rotary Fluid Motors, Meters, or Pumps are or may be essential," and so forth. What more on earth could human beings ask! The authorization, except as to terrestriality, would seem to be well-nigh adequate for angels. Yet an instrument suited to the hand of the archfiend was found elsewhere in this remarkable charter, as follows: "For the full accomplishment of the foregoing, it is the object of this corporation to adopt such special politic measures as may be desirable in maintaining efficient control of said rights, titles, and interests in all things pertaining thereto; to adopt any special system of defense or aggression cooperative with said defense," and so forth. Might the gentle art of persuasion, under such a charter, take a leaf from the long-since-discarded tactics of the National Cash Register Company? The pleasant custom once prevailed of the institution of a "Morgue," maintained at Dayton, Ohio, wherein were duly displayed all of the inventions made by competitors, with appropriate labels setting forth the dates of patent, of engaging in business competitively, and of the resultant bankruptcy or sale on the block. ${ }^{1}$ Was it not inevitable that the enthusiasm of new ideas might speedily dissipate after even a casual inspection of this interesting exhibit by aspiring inventors or intending competitors? Or there was the espionage practised by the old Standard Oil Company many years ago, through the bribery of railway employees, in order to discover the names and addresses of competitive

1 The inquiring reader will be interested perhaps to examine Trust Laws and Unfair Competition, by J. E. Davies, United States Commissioner of Corporations, Washington, I9I5; or W. H. S. Stevens, Unfair Competition, 1917. 
shippers. Happily such things are not done to-day quite so crudely, nor probably so generally, thanks to the pressure of public opinion and of antimonopoly legislation. How far they continue to exist by greater refinement of means is not quite clear. Query: Might the Cooley Epicycloidal Engine Development Company find warrant by express provision of its charter for the commission of such acts? Obviously not. Quite regardless of any such authorization by delegated grant of power from the legislature, the courts would most certainly hold it to be invalid, as contrary to public policy. The modern purely private business enterprise is quite unlike those early corporations which were specially privileged by charter, in order to perform a public function. As a corporation, it should be just as closely scrutinized and rigidly restrained as if it had preserved its individual characteristics without resort to legislative authorization at all.

An illustration of the restraining influence of this test of conformation to sound public policy is afforded by a pregnant decision of the New Jersey Court of Errors and Appeals in 1908. The Atlantic City and Shore Railroad Company had proceeded under its charter to extend its operations through acquisition of all of the bonds and stocks of a connecting railway company. It claimed its right so to do under the then unique provision of the New Jersey law authorizing its domestic corporations, contrary to the general practice, to hold stocks in other companies. The court in disallowing the arrangement thus states its objection - an objection germane also of course to the whole device of the holding corporation:-

For it must not be forgotten that stock ownership by one company in another is only a mode by which the former com- 
pany engages in the business of the latter. . . But since the second company might likewise hold stock in any other corporation or corporations, and these might do the same ad infinitum, stock ownership in any company under such a system would not evidence a participation in any definite kind of business, but in effect a participation in a "blind pool," subject to the uncontrolled will of the majority. There would be an end at once of all practical force of the doctrine that a certificate of incorporation evidences a contract between the state and the corporation or between the corporators or stockholders themselves. For an agreement imports an obligation to do some things and to refrain from doing other things. Without defining terms and bounds there can be no agreement.

Thus if the Atlantic City and Shore Railroad Company, upon being incorporated for the avowed purpose of constructing and operating a specified line of railroad ... has the unlimited power to purchase stock and bonds of any other corporation . . . it may purchase not only the stock of a traction company in Atlantic City, but the stock of a mining company in Colorado, or may participate in like manner in any conceivable business or speculation in any part of the civilized world. Its articles of association would afford no evidence, either to the law officer of the state or to intending purchasers of its shares, as to the actual scope of its activities; nor would any investor have the slightest assurance that the money he intended to embark in a railroad enterprise in Atlantic County, or the earnings of the capital already embarked, would not be diverted into schemes that he has no means of foreseeing.

So that thus, whether it concern the attempted resort of a monopolistic combination to unfair trade practices, or the misuse of such a legal device as the holding corporation, for both alike the sound principle holds good that the ultimate test is as to whether or not the practice is calculated to promote the interest of the people as a whole. To this prime requisite of public policy all other details having to do with private interest must necessarily be subordinate. 
An immense domain for juristic controversy is opened by the development of the holding-company device, as it was sought to be used in this Atlantic City case. This of course is merely an elaboration of the simple right of one corporation to hold stock in another. And the whole question of restraining the overdevelopment of the holding corporation has to do with the distinction between the necessary and beneficial as contrasted with the iniquitous exercise of this right. There is of course no inherent right whatsoever for one corporation to hold stock in another, either naturally or by implication. It is a power which may be enjoyed only to the extent that the right so to do is definitely conferred in the charter. Historically down to the classic breach with tradition by the state of New Jersey in I889, the English common law in general prohibited one corporation absolutely from holding stock in another. To be sure, there were exceptions where, for example, such securities had to be taken in satisfaction of a debt, and perhaps on occasion where subordinate or supplementary practices or processes called for the independent organization of a part of the business. This led, in the gradual liberalization of the law, - in New York state, for instance, in 1892, - to grants of power to acquire such shares in cognate enterprises. But most of the states still adhered to policies which more or less looked askance at this practice almost down to the close of the last century. Georgia and Mississippi alone perhaps held to the original rigid prohibition. The others deprecated the right by refraining from an express authorization. This left it that the mere holding of stock by one corporation in another, unless prohibited by statute, might be ultra vires, that is, not sustainable; but it was not illegal. 
Into this situation, then, New Jersey plunged in 1889 by expressly conferring the right upon one corporation to invest in the capital stock of others. No sooner, of course, was the door thus thrown wide open, than all of the other chartermongering states - Delaware, Maine, West Virginia, and the rest - promptly followed suit. And it was upon a plan built upon this basis of a hierarchy of corporations piled one upon another with a holding company at the top, that all of the so-called trusts set up a quarter of a century ago were founded. The present public utility mix-up is the natural result. Some of the charters professing to confer power without restraint are well worth examination. Among quasi-public businesses, particularly, veritable museum pieces are to be found. The articles of association of the North American Light and Power Corporation (Delaware, 1924), just to pick up a newfangled one from the pile, cover thirteen closely written pages of typewriting. But it takes more than half of these - seven pages, to be specific - to enumerate one after the other the things which it may do. It seems as if the entire store of verbs in the Century Dictionary were brought into play in order to state these powers adequately. But of course, even then, the proviso had to be added that the foregoing enumeration should not be held to limit or restrict in any manner its powers or the scope of its business.

There is another attribute of the corporation aptly set forth by Blackstone, which under present-day conditions evidently calls for review.

These artificial persons are called bodies politic, bodies corporate (corpora corporata), or corporations. When they (the individuals composing a corporation) are consolidated and united into a corporation, they and their successors are then 
considered as one person in law. As one person they have one will, which is collected from the sense of the majority of the individuals. This one will may establish rules and orders for the regulation of the whole, which are a sort of municipal laws of this little republic, or rules and statutes may be prescribed to it at its creation, which are then in the place of natural laws. The privileges and immunities, the estates and possessions of the corporation, when once vested in them will be forever vested without any new conveyance to new successions; for all the individual members that have existed from the foundation to the present time, or that shall ever hereafter exist, are but one person in law - a person that never dies: in like manner as the River Thames is still the same river, though the parts which compose it are changing every instant.

Recent experience, and a cumulative one too, demonstrates the menace of too rigid adherence to this theory of compulsory unity from the standpoint of the plain citizen and the isolated small shareholder. Danger arises from two circumstances: first, the failure properly to distinguish between the small personal business and the large publicly owned corporation; and, second, the evolution out of the substantial democracy of corporations of the "little republic" type, of those which are indeed fearfully and wonderfully compounded of all sorts of elements, sometimes concordant, and sometimes conflicting in the extreme. It is the disregard of variation in size and quality of these artificial creatures which lies at the root of some of our worst abuses. The prevalent philosophy is still that of a body in which a substantial identity of interest between all parties concerned necessarily exists. This, it is evident, is becoming each day more out of accord with the facts.

To meet the present situation there is a demonstrated need for the introduction of certain remedies, by virtue 
of which there shall be an amelioration of the law of absolute governance by a majority. Too closely has the management of corporations become identified with the use of "the steam roller." Some way ought to be found by which minorities shall have more of an opportunity, if not to block action detrimental to their interests, at least to assure a full opportunity for the presentation of their case before final action be taken. A number of recent decisions by the courts are putting heart into rebellious minorities, to very good effect. But preventives of oppression, not subsequent damages, are what seem to be needed. And, in due course, within these pages will be set forth certain proposals which are intended to give expression to the rights of a suppressed, if not an oppressed, minority. Of course one may not contemplate an actual division of authority in management. There must ever be full and concentrated responsibility in order to secure practical results. But this responsibility, it is submitted, ought by a revision of our corporate codes to be tempered by the introduction of such devices as shall in some orderly way render minorities at least reasonably articulate. In order that this criticism of our corporate practice may be concrete, attention will also be hereafter directed to such other remedies as the introduction of cumulative voting in the election of boards of directors; of a more adequate access to the stock books and to pertinent information as to the state of corporate affairs for all shareholders; and even, as in Germany, to the granting of the right to a reasonably small percentage of stockholders to call meetings and to initiate proposals for action. These various propositions are even assembled in a subsequent chapter into a general plan which looks to the creation of a permanent shareholders' representa- 
tive committee to function alongside the boards of direction. At the moment, however, it will be sufficient in this general review of corporate conditions in the United States to direct attention to the need of revision of our practice as it affects the rights of minorities.

The novel provisions at law thus far described, together with the practices springing therefrom, are but antecedent to and preparatory for the crowning infamy of all, which seems to have come to a head in the period of prosperity of $1924-25$. For without limitation of preëmptive rights, the device of no-par stock, misuse of the holding company, and an arrogant assumption of control over the issuance of securities without sanction of the stockholders, all alike coupled with an attempt to set up a bulwark against liability of the management for harmful results to the corporation itself or to its shareholders, the attempted rape of the voting power would have been more or less ineffectual. Such interference with the right of the franchise, however, reaches so much deeper down in to the heart of things, not being concerned merely with the details of corporate direction, that it must be taken up in the next chapter by itself. 


\section{IV \\ GIVING UP CONTROL \\ A BIRTHRIGHT FOR POTTAGE}

Once upon a time, - and it was n't so long ago, either, down in Boothbay, Maine, there were two brothers, John and James. Their last name was Doe. John, the elder, was quiet-eyed, slow-moving, and comfortable, temperamentally. James was more jumpy, nimble-witted, ambitious to get on. One stayed on the farm; the other naturally gravitated to the city. In due season John's boy prepared to enter the academy at Damariscotta. Said his father: "Son, you 're getting grown up. Suppose I die - you ought to have something all your own. I'm going to give you that best Jersey heifer. But you must remember to keep her well fed and healthy so that the milk will be pure. And keep her horns cut, in case she gets pernickety. Remember also that the fence in the northeast corner of the pasture is getting shaky. She might wander out on the highroad and upset somebody in a Ford. Because she's all yours, it's up to you to see that she behaves herself."

About the same time James, in the library of his city house, thus delivered himself to his son: "Now, Junior, before you go to college I want to give you my investment in the Boothbay Harbor Electric Light Company. This concern serves our old neighbors and friends, and I want you to feel a continuing interest in, and a responsibility for, our share in this local enterprise. If properly 
managed it should be a benefit to this community; and it will yield you an income to be applied to your education through the next few years. But you must never forget that you are partly responsible for this undertaking. Our family had a hand in starting it. That responsibility is an inseparable part of your ownership. I read something the other day, in an opinion by Justice Brandeis of the United States Supreme Court, which bears this out: "There is no such thing to my mind . . . as an innocent stockholder. He may be innocent in fact, but socially he cannot be held innocent. He accepts the benefits of the system. It is his business and his obligation to see that those who represent him carry out a policy which is consistent with the public welfare.' $\mathrm{He}$ is right in that. This accountability for wealth underlies and justifies the whole institution of private property upon which the government of our great country is founded."

Thus did two men, good and true according to their several lights, recognize the public obligation that attaches to wealth. But how different were the results! The son of John, under the old simple conditions, continued to cherish, and in the community to stand sponsor for, his Jersey heifer. But with the son of James complications speedily developed. First of all, the Central Maine Power Company, heading up in Augusta, induced a majority of the stockholders in the local corporation, which, by the way, seems not to have been doing very well, to exchange their holdings for shares of the larger concern. There was nothing else for it but to follow along. Then a great consolidation was announced. It was headed by the Middle West Utilities Company, incorporated in Delaware, which took over the Central Maine 
Power Company and made it a part of an intermediate corporation, known as the New England Public Service Company, which through the Manchester Traction Light and Power Company and the National Light and Power Company (which latter itself owned the Twin State Power Company and the Vermont Hydro-Electric Company) covered all northern New England. Thus, by the close of 1923, the son of James had become a partner with 53,999 others in a joint investment of over $\$ 52,000,000$ in stocks alone. The main office of the company had moved to Chicago (the annual meeting still being held in Delaware, however). The little New England corporation was now indissolubly bound up with five others in Illinois, three in Indiana, three in Kentucky, two in Oklahoma, one in Oklahoma and Texas, one in Missouri, one in Michigan, two in Nebraska, two in Virginia, one in Wisconsin, and one in Tennessee. This was the chain, constituted of many links, which made up the sole and tenuous connection between the son of James and his original electric light investment. It began to look indeed as if the days of the simple life and of direct responsibility of ownership were by way of passing in the field of public utilities in New England.

James and his son, thus lost in the shuffle of public utility corporations, turned to the field of private enterprise, in which, as they had been told, personal initiative still held sway, free from the deadening influence of governmental supervision. They perused the offerings of securities in the press by well-known and responsible firms. Might they not hope to acquire direct ownership in corporations which themselves managed the business? The first stumblingblock was the holding corporation. They had become used to this complicated financial 
device in the large concerns like the United States Steel Corporation or the General Motors Company. They sought for less stupendous undertakings. One banking house offered gold notes which invited participation in the affairs, not of the Kaufmann Department Stores, Incorporated, "conducting the largest department-store business in the city of Pittsburgh," but only of a holding company, the Kaufmann Department Stores Securities Corporation, a finance or intermediate company. Another offering was of Stern Brothers, New York, "one of the oldest and best-known department stores in the United States," but "to ensure continuity of management and policy the common shares will be placed in a voting trust." Perhaps they sought an interest in the biggest hardware company in the United States. They found, however, that the Associated Simmons Hardware Companies merely controlled an immense business in St. Louis, deriving their status as a legal trust from Massachusetts. The DeForest Radio Company offering was yet otherwise eviscerated of all possible voting power by another kind of voting trust.

Coca-Cola sounded refreshing. A company chartered in Georgia turns out some 25,000,000 gallons of a popular beverage, presumably at a profit. The stock is publicly listed and very widely held. But some 251,000 of its 500,000 shares were found to be lodged in the hands of a knot of insiders, incorporated as the Coca-Cola International Company. No shares of this corporation which held control were listed or available as a purchase to James or his son. Answering an advertisement of securities of the Associated Gas and Electric Company, they found that its business was really conducted at the office of the Associated Gas and Electric Securities 
Corporation - another finance company? From Armour and Company of Delaware, whose common stock was all owned by Armour and Company of Illinois, down to the latest offering of a dairy-products concern, everything was tied up in this way. Hopeless indeed did it appear that any uninitiated public investor could understand, much less participate intelligently in, any of these affairs.

Nor was James wholly blameless for the loss of direct contact and responsibility between his son and his investment. For, finding himself getting on in years and being mindful of the mutability of human affairs, he might have taken out a charter as "James Doe, Ltd." - better, perhaps, than "Inc.," because carrying the suggestion, among other things, of a limited liability for inheritance taxes. His son and his wife, holding practically all of the stock in this immortal creation, no investments coming to them upon his death would cause a ripple in the Probate Courts. Or he might have put his possessions in a private trust, managing it himself as trustee during his lifetime, thereby splitting up the income and still further reducing taxes. Or the management of this "living trust" might have been turned over to a professional trust company. And any one of these agencies might in turn have purchased "Collateral Trustee Shares in the New England Investment Trust, Incorporated, the First National Bank of Boston, Trustee," or some similar investment concern, properly enough intended through diversification to spread the risk. And, finally, there' was the life-insurance policy, based entirely upon investments to be handled by these great fiduciary corporations for him as agent, at the longest possible range. 
What an amazing tangle this all makes of the theory that ownership of property and responsibility for its efficient, farsighted, and public-spirited management shall be linked the one to the other. Even the whole theory of business profits, so painstakingly evolved through years of academic ratiocination, goes by the board. All the managers, that is to say the operating men, are working on salary, their returns, except on the side, being largely independent of the net result of company operation year by year. The motive of self-interest may even have been thrown into the reverse, occasionally, so far as long-time upbuilding in contradistinction to quick turnover in corporate affairs is concerned. And what has become of the relation between labor and capital? What guaranty may possibly be given by the real owners to the working class that there shall not be taken from it an opportunity for future welfare and development as a result of these changes? The protracted struggle of the textile workers in 1926 at Passaic, New Jersey, has undoubtedly been prolonged by the absentee ownership and involved financial structure of some of the companies, the Botany Worsted Mills in particular. Veritably the institution of private property, underlying our whole civilization, is threatened at the root unless we take heed. The situation is not inaptly described by the colored candidate for the ministry, confronted by the request of the examining Board of Preachers to name some character in the Bible and then to relate all that he knew about it. "Ah thinks Ah'll take Jezebel. Jezebel, she was a hussy, a-settin' up at a winder when David come down along th'u' Jerusalem. An' she hollered at 'im. An' he said, 'Ef I got a frien' up there, let him th'ow 'er down.' An' 'e had a frien' up there, an' 
'e th'ow'd 'er down. An' David said, 'Let 'im th'ow 'er down again.' An' 'e th'ow'd 'er down again. An' David said, 'Let 'im th'ow 'er down, seventy times seven.' An' 'e th'ow'd 'er down seventy times seven. An' she busted into a thousand pieces. An' they gathered up the fragments that nothin' be lost. An' de question are: Whose wife am she at de Reserrecshum?" It is a query which might well be propounded at this time to several millions of our fellow citizens, in so far as they are part owners in the $\$ 70,000,000,000$ capitalization of American corporations, according to the federal tax returns, in the year of our Lord 1923 .

Thus far, however, the multiplication of these entanglements constitutes no innovation. They have been going on for a long time, insidiously undermining the principle of accountability. The individual and partnership forms of business organization disappeared in favor of the corporation even before the war. Well-nigh a thousand companies are now listed on the New York Stock Exchange alone - 163 railroads and 763 other corporations in 1924. But since the World War, and particularly in this heyday of prosperity, the facile initiating and legal minds have hit upon something better yet and something, furthermore, which puts once and for all at rest the last vestige of power of participation of the owners of property in prudent and efficient management. The two twelvemonths, I924-25, promise to go down in history - like the Year of the Plague, or the Year of the Big Wind - as the Years of the Split Common Stock and the Vanishing Stockholder. ${ }^{1}$

Since the days of old Blackstone the corporation, as

1 W. H. S. Stevens's “Stockholders' Voting Rights and the Centralization of Voting Control" (2uarterly Fournal of Economics, May 1926, pp. 352-392) is the most complete catalogue of the existing practice. 
we have seen, has been likened to a "little republic" set up for the accomplishment of some private purpose. And, the essence of full democracy being the exercise of the franchise, there appears to have been but little restriction of the voting rights of shareholders. For railroads this has always been true. Both the preferred and common shares of such companies have been commonly full voting issues. Apparently the practice of setting off preferred shareholders as nonvoting had not been invented when the great development of industrial combinations from 1898 to 1903 occurred, during which time approximately two hundred of our so-called trusts came upon the stage. The reason for this is obvious. Most of the individual concerns which went into such combinations as the Steel Corporation, the American Woolen Company, or the American Shipbuilding Company were in part acquired by inducing the owners of these concerns to accept preferred shares in payment for their interests. The amount of these particular issues was in those days adjusted to the tangible assets, leaving the common shares to represent the equity. The value of these common shares was thus made dependent upon successful management. But it was unlikely, therefore, that, having thus committed themselves to participation in the new enterprise by taking preferred stock, the former owners should have been willing to relinquish entirely their share in management. An occasional company - International Silver, for instance, or Federal Mining and Smelting, or Royal Baking Powder Company - somewhat restricted the franchise for its preferred shareholders; but not even as late as I9II-I2, when the great merchandising companies made their appearance, does the full significance of this device seem 
to have been appreciated. And then, little by little, came the practice of setting off the preferred shareholders, depriving them of the right of participating in the election of management. Nor yet, thus far, was there any distinction introduced among various classes of the common shareholders.

The latest invention for prying people loose from their possessions now splits up these common shares. To be in the mode one has, let us call it, a "Class A participating" common stock, with a first lien on earnings after satisfaction of all prior claims of preferred stocks and bonds. This leaves a "Class B" common stock representing, according to circumstances, the cream, the scum, the froth, or the sediment of the business; for the full voting rights attach exclusively to these Class $\mathrm{B}$ common shares, none, or only a minority, of which are offered to the public at all. The appetite for the preferred shares may sometimes be whetted by a flavoring of the Class A common shares, but not of those which carry votes. "Dodge Brothers, Incorporated," is typical. A banking house buys up a private business for, it has been said, $\$ 146,000,000$ or thereabouts. This sum, and more too, they recover - if the plan works out - by the sale to the public, for $\$ 160,000,000$, of bonds and preferred stock at par and $1,500,000$ nonvoting shares of Class A common stock. But not a single one of the 500,000 Class B voting (no-par) common shares is thus sold. The promoters have virtually paid themselves a handsome profit for the assumption of the entire directorial power, having mortgaged the property to the full amount of its original cost through outstanding bonds and preferred stock, including both assets and capitalized earning power. And the amazing thing is that this final 
deathblow to the exercise of voting rights by the general public has brought no voice of protest. Yet the plan bears every appearance of a bald and outrageous theft of the last tittle of responsibility for management of the actual owners by those who are setting up these latest financial erections. Is n't it the prettiest case ever known of having a cake and eating it too?

Perhaps the baldest case is of an artificial-silk concern, the Industrial Rayon Corporation, with 598,000 shares of nonvoting Class A stock distributed to the public with the reservation of the remaining 2000 out of 600,000 shares, as Class B stock, carrying exclusive voting rights. Or the invitation to participate in a well-known root-beer enterprise with 180,000 shares of Class A and Class B common shares with the concentration of control in 3872 "Management Shares." It savors rather of supererogation to add in the prospectus, "The management of the company will remain unchanged and continue in charge of the members of the Hires family." Or take, if you please, a well-known theatre enterprise, said to have over $\$ 20,000,000$ in assets. There will be $4,000,000$ shares - 3,900,000 Class A shares to be sold to you and me, and 100,000 Class B shares, in which will be vested exclusive control through voting rights. The Class $\mathrm{A}$ and Class B stock participate in dividends on exactly the same basis. But all of the power over management is stripped from one and conferred upon the other.

Universal Chain Theatres Corporation hits the bull'seye hard. First there is an issue of $\$ 4,000,000$ of first preferred stock. This is followed by $\$ 2,000,000$ of second preferred. Then come 199,000 shares of no-par common stock. Who is to run the concern? Why, the happy holders of "Management Stock," of course! This issue 
is created, defined, protected by reservations of all kinds, and exclusively reserved, without cost, by the people whose name it bears - The Management. The share of the public is simple. All it has to do is to put up the money. The Management does the rest.

Nor do these amazing arrangements set modest time limits for themselves. Voting trusts have been compelled to do so by the courts, their duration customarily being limited to ten years. One company, which proposed in 1926 to solicit public investment through the usual channels, arranged for so-called "Management Stock," a few hundred shares only. Voting rights for the public, invited to subscribe to Class A and Class B common shares, were to be equal all round, "except for the election of Directors at stockholders' meetings held on or before December 31, 1960." This particular charter then goes on to provide: "All shares of Management Stock shall be nonassignable and nontransferable, to the end that at no time shall any of the rights incident to the holding of shares of Management Stock in any manner be vested in or exercised by or on behalf of or for the benefit of any other than the three persons named above. Any attempt by any one of such three holders ... in any manner to transfer or assign any legal or equitable right, title, or interest in respect thereof, or the death of any such holder of shares of Management Stock, shall ipso facto operate as a conversion of such shares into Class B Common Stock," and so forth. But hold! All is not lost. "On and after January I, I96I (or on and after any earlier date upon which all of the Management Stock shall have been converted), all shares of all classes of stock shall have equal voting rights on all questions." What a delightful plot to develop into a story like Frank 


\section{A BIRTHRIGHT FOR POTTAGE}

Stockton's inimitable The Wrong Box! What fun to see how such a plan for control would ultimately work out in a quarter century or so!

There is no concealment about all this. It is perfectly open and above board. But who, we ask, under these circumstances has really given a hostage to fortune, to the public, or to the employees for honest and economic management of the business? The promoters stand to lose only the amount of their stake - a minus quantity in dollars in so far as the nonvoting shares have been made to cover not only the value of the tangible assets but the prospective capitalization of earnings. It is the public stockholders, the consumer and the wage earner, who stand to lose in event of misdirection. How can there be other than a whirlwind of abuse of power under such conditions?

Nor is it our great basic industries which are being swept by this plague. Most of the great combinations had their rise twenty-five years ago, with a minor outbreak in I9I I-I2. To-day it is neither the Steel Corporation nor the Harvester Trust nor the railroads which are following these newly beaten paths. Look at the newspaper offerings. The public is buying out the mailorder, chain, and department stores, foodstuff manufacturers, the makers of washing machines, refrigerators, confectionery, make-believe-silk stockings, toilet and beauty preparations, music, tags and napkins, phonograph records, pianos and radio outfits, theatres, our daily bread, our ice cream, root beer, cake, and even our homemade pies. At this rate every conceivable article of direct or indirect consumption will soon be more or less in the hands of the general public.

Most disconcerting is it when this latest financial 
development invades the field of public utilities, already sufficiently cluttered up with holding companies and trusts. The older and conservative companies are above criticism. But one takes exception to the offerings of the Southern Gas and Power Corporation, with an authorized note issue of $\$ 2,000,000$, preferred stock $\$ 5,000$,$\infty 00$, and Class A 250,000 shares, leaving the exclusive voting power, except in case of default in cumulative dividends, in 100,000 shares of "common stock, without par value." It is these last which are not offered to the public at all. This organization controls operating companies in thirty-seven communities, scattered over eight different states. Was there ever a clearer case in an essential public industry of what has been well defined by an expert as "one of the besetting sins of modern corporations ... the custom of trading on a thin equity, control resting in the hands of common stockholders, while the funds are supplied by the sale of preferred stocks and bonds"? Had this author written in 1925, he would have added " and even of a large number of common shares which have been stripped of voting power." Then he would have hit several nails squarely on the head with one rap of the hammer.

Much confusion nowadays doubtless results all along the line because of the necessary intermingling of entirely different functions which has accompanied the growth in the size of the business unit. Callings have become sufficiently specialized to constitute each a profession by itself. Bankers, on the one hand, have, sometimes perhaps against their will, sometimes by veritable force of it, been projected into the centre of an industrial situation. A business may have outgrown the financial capacity of the purely operating men. Indeed this 
happens whenever the business, whether it be New England Cotton Yarn, American Beaver Board Company, or the Goodyear Tire and Rubber Company, becomes overextended, as so many did in 1920. But the banker, thus assuming industrial responsibilities, has an entirely different perspective from the operating man. His attention tends to gravitate toward the marketing of securities, the course of quotations, and the like. He has an interest in dividends in their relation to market quotations rather than in their relation to mechanical processes. His shortcomings, standing alone, are as evident as are those of the operating staff. The operating people, on the other hand, are always calling for more money for amplification of facilities, without always perhaps having clearly in mind the possibility of earning a satisfactory return thereon. They want to see the wheels go round. The banker's query is first and foremost: How much will it cost and what will be the return?

This contrariety of interest, even under the best of circumstances, is apt to lead to strain and misunderstanding. On the other hand, it is equally awkward when operating men, by reason of the growth in magnitude of a business, find themselves overburdened with great problems in finance. The failure of Westinghouse in 1907 was distinctly due to the inability of a great engineer to envisage the financial future. The collapse of Rumeley Company eight years later is traceable to the same defect in personnel. The fact is that two distinct and yet interrelated activities dovetail into one another in great enterprises. And whenever either the banker on the one side or the operating man on the other seeks to go it alone there is like to be disaster. Each needs to lean upon the other. But inherently it is more 
often the banker, the financial man, who in the struggle for survival comes out on top. This it is which creates the situation wherein the power of the banker, springing at bottom from the use of the funds of all the people, is first applied to subjugation of the operating group; and then, to cap the climax, seeks to reduce the great body of the shareholders to subjection. This is the situation we find confronting the United States in 1925 .

Nor is the situation peculiar to our own country. It springs from the overelaboration of the device of the stock corporation. An example in England is strikingly depicted by A. G. Gardiner in his Portraits and Portents, recently published. The pyramiding of control of the British press by Lord Rothermere, through majority ownership of the 700,000 shares of the Daily Mirror Newspapers, Limited, enables him to control a share and loan capital valued on the Stock Exchange at

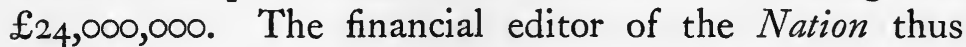
describes it: "Lord Rothermere assumes a minimum of personal risk. ... The public put up the big money and Lord Rothermere kept control." Thus is created "the master of the greatest machine of publicity the world has ever seen."

A technically correct and restrained description of the existing situation is this one by A. A. Berle, Jr.: " "The investment banking house is invariably in the centre of a web of economic interests, to which it renders a real service and from which it derives a real return, but which affords possibilities for profitable transactions not necessarily benefiting the controlled corporations. While the banker's action may be adequately regulated by a high sense of banking ethics which largely prevails

1 Harvard Law Review, April 1926. 
among reputable houses, the law can hardly leave investors subject to the doubtful protection of private consciences."

From England there happens to come news of an apposite occurrence. It depicts a financial shipwreck, wherein it is impossible to fix the blame upon anybody in particular. British Controlled Oil Fields, Limited, has just collapsed, with a resultant loss of about two thirds of the original capital, which amounted to $£_{45}, 000,000$. Everybody seems to disown responsibility for the debacle which took place in 1926. The voting trustees declare that their trust was created primarily to prevent the capture of control by foreign interests and that "the management of the company's affairs does not come within the ambit of their powers." The directorate, on the other hand, - which is now ousted, - apparently points to the real source of power as resident in the trustees. And thus, while each puts the blame on the other, the shareholders foot the quite considerable bill.

A most engaging picture of the banker's function in industry is presented by one of the proponents of the modernist practices. Says De Roode:-

"We cannot regard what I call organization capital in the same light that you regard investment capital. . . . Investment capital properly speaking looks for a return in the nature of interest; organization capital does not figure on interest, it figures on profit. ... There is no need of pretending that it is not so. The people who put a big industry together want to sell it; they want to sell it at a profit. . . . They want to retain control because they are always left with some holdings in it."

Or again: "The economic value of nonvoting stock is that it effects economy in distribution and enables the 
investor to participate in industry more cheaply and hence more profitably. . . . A large amount of capital, for example, is necessary to finance the combination of a group of industries or enterprises. This capital will not go into such financing unless it obtains control. If to maintain such control this initial capital or a large part of it must be kept permanently in the enterprise, a higher price must be charged for that part of the capital which is sold to the public.

"Now this financing capital, or what we might call 'organization capital,' is frankly not content with the mere return obtainable from the industry. This capital is not looking for a return upon an investment; it wants profit. . . .

"If, on the other hand, therefore, the mechanism of nonvoting stock control may remain with the organizers and the greater part of their capital be quickly released, the price to the investor for participation can be ... much less than where control is dependent upon organization capital remaining permanently in the enterprise.

"In other words, this organization capital gets a quick and relatively small profit and, retaining control, moves on to the next enterprise." [Our italics.]

Was there ever drawn a more entrancing picture than this of the banker's function in industry? This busy "organization capital" bee, "with honied thigh," in Milton's words, buzzes from one flowery situation to another, extracting the precious nectar of control and just incidentally powdering the public with the preferred pollen.

There is of late another financial practice, also, which greatly accentuates this nullification of the ordinary shareholder. This is the wide distribution of stock to employees and the consumers of the corporation's product, 
whether electric service, steel, or what not. ${ }^{1}$ The effect in any event is bound to be cumulative with that of the insinuation of professional management power between ownership and operation.

Corporations have always been susceptible to control by concentration of voting power. Far less than half of the capital stock may be as effective for such control as possession of an actual majority. But it is elemental requiring no proof - that, the larger the number of shareholders, the more easily may a small concentrated block of minority shares exercise sway over all the rest. With a dozen owners, probably $5^{1}$ per cent will be necessary for dominance. With 300,000 scattered holdings, a possible 15 or 20 per cent of the votes can never be overmatched at an election. In I923 there were 250,000 new stockholders registered in the electric light and power companies alone. The total number of stockholders in all sorts of concerns has almost doubled since I900, rising to an aggregate of $14,423,000$ in 1923 . These shareholders now possess over $\$ 70,000,000,000$ worth of stock at par, on the showing of the federal income tax returns. Such possession used to be confined to the wealthy and the well-to-do class. Now it comprehends the small householder and large numbers of wage earners. The former concentration of wealth is now yielding place to so wide a diffusion as to call for public recognition by way of legislation or oversight. But the important point to note is that the wider the diffusion of ownership the more readily does effective control run to the intermediaries. Financially, the matter is dangerous, for it tends to transform a contingent outstanding charge upon earnings into virtually fixed charges thereon. The cessation of

${ }^{1}$ For further details consult Chapter XI, infra. 
dividends, either to employee holders or to consumers, is bound to be so productive of discontent and unrest that every nerve will be strained to the utmost, even overlong, to prevent their cessation.

It is at just this point that some of the provisions at law, particularly those which abrogate the shareholder's rights to participate in new issues of securities, come into play. Such clauses, with devilish ingenuity, look sound enough above the water line; but they certainly will not stand examination in dry dock. For not only has the shareholder parted with every vestige of control of the enterprise represented by his investment, but now he makes a free gift of such rights as may accrue, resulting from future growth of the property. Heretofore it has been a fundamental rule in corporation law that there shall be no discrimination whatsoever between shareholders. Discrimination there may be between creditors and owners; but by this device even the common shareholders are now set off, to the end that an inordinate share, if indeed not all, of the increment of profits in future shall attach to the holdings of those who are "in the know."

Why do stockholders submit to such indignity? The technique is simple, relying upon a fundamental attribute of human nature. Mr. Robert F. Herrick of Boston, in a frank address on holding companies, describing the manner in which the exchange of shares in one corporation for those of another may be brought about, thus puts it: "All the stockholders act like a flock of sheep. In the main they follow the lead of the directors, and if the details of carrying the plan through are so arranged that the stock in the new company has an apparent money value greater than the stock of the old company for which 
it is offered, the exchange once started takes place generally, and when a majority of the stock in the companies is exchanged, practically the consolidation is effected." There you have it in the words of an expert!

The docility of corporate shareholders permitting themselves to be honeyfugled or dragooned into exchanging securities of one corporation for another, is responsible for a considerable part of the loss of shareholders' rights of one kind or another nowadays. We are now in the midst of a veritable mania for such horse trades. This is what "Magpie" in the Stock Exchange Gazette of London has to say about it: -

I understand that holders of Lago Oil and Transport will shortly be offered Pan-American B shares in the ratio of one for every three Lago shares held. Not long ago these Lago shares were given out in exchange for Lago Petroleum shares, which in their turn were distributed in exchange for British Equatorial Oil shares. I always have a feeling that the shareholders are losing something when they are offered these exchanges, for I am quite sure that the Americans don't give anything away; but if the majority accept, it is generally advisable to join with them, because it is awkward for the individual shareholder to be left with shares which have no market.

In the field of public utilities the hoodwinking of the shareholders out of the franchise is going on apace. Preferred stockholders in a company - Virginia Railway and Power, for instance - may have been entitled to six-per-cent dividends, noncumulative but possessed of voting power. The invitation to exchange for new sevenper-cent cumulative preferred shares is too inviting to permit question as to whether the elimination of voting power is worth while or not. Possibly this abrogation of voting rights is essential to the building-up of an efficient combination. In this instance it looks as if it were. 
Possibly also the charter provisions afford adequate protection to this particular issue. But the loss of the shareholder's right to vote is no less a fact. In another instance of one of these public utility companies the shareholders in the original company, incorporated in West Virginia, had the right of cumulative voting. But, having exchanged their stock for a Delaware corporation, they woke up to find themselves stripped of that rather valuable right. A somewhat similar elimination of the franchise by a rearrangement of subsidiaries in the American Light and Traction Company seems recently to have been thwarted by the resolute opposition of a minority which discovered the fact in time. And so it goes with these shareholder sheep. As long as an offer "looks good" they follow the leader, even though the circumstances as respects their rights may be "as dark as the inside of a cow," to borrow a phrase from the Kentucky mountaineers.

It will be objected that no real change is involved in these recent tendencies: that stockholders never did, and never will, exercise their voting rights. In fact the great trouble, oftentimes, is to secure enough proxies in widely owned corporations to validate the acts of their directors. But the fact remains that the power, even if rarely exercised, and then only under extreme provocation, was there; and every once in a blue moon some resolute individual or stockholder could rise in his place and organize a protective committee or dissenting group - and, if nothing else happened, at least there was a thorough ventilation of what sometimes proved to be a musty or unsafe tenement. Furthermore, one of the most encouraging things in life is the influence that can be wielded 
by an individual, acting almost single-handed and alone, to confront and often to overcome a corporate Goliath, provided he has the right on his side. My mind runs to the extermination of the Louisiana Lottery by a former colleague, Professor Homer Woodbridge: think of it professor of heating and ventilation at the Massachusetts Institute of Technology! Or recall what Charles and Philip Cabot achieved in bringing about the elimination of the seven-day week and the twelve-hour day in the United States Steel Corporation! Or Lois Burnett Rantoul, undauntedly facing down every corporate influence in the Massachusetts Legislature, and bringing about the enactment of the first eight-hour-day law for women and children in the United States! Such things as these give one good heart, leading to the belief that the power of personality, alone, may' win the most astonishing victories in the face of overwhelming odds. But all such achievement in this field of management of property is closed out forever once the people who own that property have allowed themselves to be utterly divorced from the exercise of their natural right to elect the directors and to influence, if not to determine, the corporate policy. For by such an abdication they give themselves over, body and soul - becoming mere wards, non compos mentis, so far as control over their own affairs is concerned. It is all so absurd, theoretically, that it seems incredible. Yet here are the facts!

But if the trend of corporation law and practice has been so consistently in the direction of diminishing rather than of accentuating the responsibility and accountability of the real property-owners, what is to be done about it? This, to my thinking, is a matter of vital concern to the successful functioning of our capitalistic system. For, at 
this particular juncture, the final deathblow to such accountability seems to be in the very act of delivery. Many suggestions have been made from time to time; some of them have already been successfully applied to our railroads. A few now bear upon our other public utilities. But absolutely nothing has yet been done to stem the current, much less to reverse it, as respects private business corporations. Something, to be sure, has been accomplished in the way of enforcement of liability for downright mismanagement or negligence, as against directors. But all such remedies, even when successfully invoked, - as for example on the New Haven Railroad, in the Old Dominion Copper suit, or in the well-known American Grass Twine and American Malting Company proceedings about I903, - are but cases of hanging the murderer after the innocent victim has expired. The reliance upon the courts, also, at best entails protracted and expensive litigation. Furthermore, too great an increase of such liability of directors, with the possible harassment of blackmailing or other proceedings, might readily enough make it impossible in future to secure the services of really able and responsible persons. Something may possibly be accomplished in this direction, but other and simpler remedies would seem to lie more nearly within reach.

Why not restrain the holding company? "Swat it!" says one public spokesman. I would do so; yet ever with a nice discernment. The fly-bluebottle, horse, domestic, or gad - is always a pest. Not so the finance corporation. It has its proper place and function in the scheme of things. But within that domain it should be rigidly confined. The very complexity of our form of government, involving relationships which transcend state boundaries, 
almost inevitably brings forth a litter of creations deriving their powers from the governments of the different commonwealths. This is a necessary outcome of the local demand for compliance with local needs. Piling of one corporation upon another also simplifies finance and management, augmenting credit and enabling largescale operation and the employment of higher-paid technicians. But it is also true that a large part of this complexity is the result of a deliberate intent to assume and concentrate power in the hands of an inner circle. The primary test of good faith is mathematical. When the Associated Merchants Company (of Connecticut) controlled, as it once did, the H. B. Claflin (dry goods) Company (of New Jersey), which in turn owned the operating H. B. Claflin and Company (in New York), by ownership of 45,00I out of 90,000 total shares, appearances are certainly against the arrangement; but when, as in the Continental or Purity Baking Corporations, recently set up, a bona fide attempt is made to secure all of the shares in the many operating concerns, the advantage and even the necessity of the plan are obvious.

Wade Ellis, the then attorney-general of Ohio, speaking twenty years ago, stated, in words which now seem prophetic, the case against the holding company:-

"This is the most effective, the most invidious, and the cheapest of all combinations in restraint of trade. It is the most effective because, while agreements, and especially unlawful ones, may easily be broken, a transfer of the stock puts the bargain beyond the power of any conspirator to escape. It is the most invidious because, while it conceals all, it fears no exposure. It is the cheapest because it requires less money to buy a controlling interest in the stock of the competing companies than it 
does to buy their property, and yet the promoters have the use of the investment of all the minority holders in all the corporations brought under their control. In fact it generally requires no money at all, for the stock in the subsidiary companies is paid for in the stock of the holding company. Thus a vast industry is brought under the domination of manipulators whose circulating medium would not be a legal tender anywhere except on the stage."

I venture to suggest the possibility of drawing the line between the use of such a device to concentrate control in the hands of insiders, contrary to public policy, and the performance of its legitimate function in the field of business. What a dull and rigid life as human beings we should be compelled to lead, if our backbones were fashioned all in one piece. Even a corporation, to my thinking, may benefit from a proper amount of articulation. But it need not be a vaudeville contortionist, for all that!

What shall be said of the proposition that bondholders should be given voting rights, pari passu with the stockholders? One of the first acts of Governor Roosevelt of New York in I900 was to appoint a special commission to draw up a model Companies Act. Section 61 of this proposed statute made it permissive to confer voting power upon debenture- and bond-holders "equal and equivalent to the stockholders." The corporate code of Delaware expressly provides for such a grant by articles of association. Most eminent legal talent supports this contention with reference to railroads. I have always believed it desirable and feasible whenever it is apparent that the real capital in the enterprise was provided through the sale of bonds, leaving the stock merely to represent real or anticipated capitalized earning power. Too often in the early days this used to be true of rail- 
roads. Many of them, however, have now waxed prosperous enough to fill out the measure of their financial clothes. The present situation among purely private corporations, in this instant wave of transformation, thoroughly supports the proposition that for many of these companies practically all of the real capital is advanced either by bondholders or by those who hold preferred stocks, which are in reality bonds. They are bonds in every vital respect, except that they have no foreclosure rights. But the preferred stocks have been bereft of all voting power, except and until the cessation of dividends. The amount of them issued, moreover, coupled with the Class A participating or nonvoting common stock, not unusually nowadays equals the full measure of material assets, plus capitalized present and prospective earning power. The proposition to enfranchise the bondholders, at least, is yet further fortified by the fact that the great life-insurance companies, which ordinarily confine their investments to bonds, have at their disposal expert financial talent of a high order, which might serve most acceptably upon the directorates of many of these companies - say, for example, public service corporations of the larger purely private business concerns.

The objection offered whenever I have advanced this proposition is that the bondholder is a "money lender" and that his intrusion into management "ignores the private property rights of the stockholder." Stockholders, forsooth! Who are they, indeed, in Dodge Brothers, Incorporated, where the only real stockholders - that is to say, those who have any power of direction - are bankers who have, for a handsome consideration to themselves, condescended to strip all the voting power from 
three quarters of the common shares - that portion alone which is sold to the public. Perhaps somebody will have the temerity to maintain that the remaining quarter - of Class B common shares, having "exclusive voting powers for all purposes," which the bankers retain for control - as exclusively represents the real owners of the property. Tush! Everybody else is no more a stockholder, so far as management is concerned, than is the elevator boy or the apple woman on the corner.

Another pulmotor for the possible resuscitation of this moribund stockholders' responsibility is that of cumulative voting. For ten years past it has been my privilege to serve as a director of the Rock Island Railway, whose ancient charter, Section 9, permits each stockholder either to vote "for as many persons as there are directors to be elected, or to cumulate such shares and give one candidate as many votes as the number of directors, multiplied by the number of his shares of stock, shall equal, or distribute them on the same principle among as many candidates as he shall think fit." That proviso put a watchful minority at the switch, at least until such time as mutual confidence and friendly relations all round had cleared up the situation. Thus is the standard provided of at least a temporary two-party system, which conforms to the praiseworthy criterion set by the Railway Age, "that there should be someone continuously watching the detailed operation of the road in the interest of stockholders, other than the controlling interests, and in the interest of bond- and note-holders." Many of the great British banks, including the Bank of England and the London Westminster, graduate the voting power of shares, to prevent superdomination by the large stockholders. Granted that the proposal needs safeguarding, to pre- 
vent obstructive and hold-up tactics, it nevertheless embodies a principle worth consideration. We ought to be adopting the practice to-day, instead of splitting off the management shares from the main body of the capitalization.

The principle involved in cumulative voting is well stated in the original Michigan Corporation Law of 1885 , reënacted in I92I. This provides that all shareholders shall have "the right to vote in person or by proxy, according to the number of shares of stock owned by him for as many persons as there may be directors to be elected, or to accumulate such shares and give one candidate as many votes as will equal the number of directors multiplied by the number of shares of his stock; or to distribute them on the same principle among as many candidates as he shall think fit." This particular statute has had a significant history. During the last forty years it has been repeatedly attacked, whittled down, actively debated, over and over again, the attack and defense being clearly distinguishable as springing, the one from the legal mind in direct employment of business interests, the other from the general sentiment that the law was fair and reasonable. Some ten other commonwealths, more or less, now permit corporate elections to be handled in this fashion. Pennsylvania even goes so far as to require that all elections under the Pennsylvania charter shall be so conducted. The principle was actively endorsed as far back as 1880 under an investigation made by the New York Chamber of Commerce. Governor Roosevelt's Commission in I900 recommended the adoption generally. First-class corporate authority, however, both lay and legal, recognizes its validity for the purpose of tempering unduly autocratic management. And it is 
of interest that the device has been quite widely adopted in Europe; so-called "plural voting" shares being quite common both in France and in Germany. Yet curiously enough the object in these countries seems to have been to prevent seizure of control by foreign capital - a measure of protection against aggression rather than a reenforcement of minority interests. Obviously the knife cuts both ways, but the right of cumulative voting would seem to make for a somewhat keener competition for first place and power than now, to that degree serving as a check upon inefficiency and as an incentive to meritorious performance. As a practical matter, however, it must be confessed that in states like Michigan, which have pottered with the practice for many years, little seems to have been accomplished. Yet all agree that, when factional strife develops, the device operates beneficially for the protection of the minority. It is agreed, furthermore, that the existence of the law prevents friction and has been of substantial and constructive value for that reason. It is said to operate like a policeman's club - "only occasionally used, but it serves a very useful purpose and while idle does no harm."

Inside control in practice often relies upon the voting rights attaching to floating stock in the market - that is to say, stock which is passing so rapidly from hand to hand that for convenience' sake it remains often for many years registered in the name of banking or brokerage houses. And in the case of non-dividend-paying corporations the proportion of such floating stock may be so great as, in and of itself, to carry control. And a system not unlike logrolling among Congressmen, under such circumstances, enables interchange and common understanding along the "Street" to perpetuate control by 
those who may not in fact have a dollar of actual stake in an enterprise. It has been proposed to disfranchise such floating stock. It might be serviceable to do so; but the practical difficulties in the way of carrying out such a plan seem to me insuperable.

The only thing that seems to keep the world going under the law of natural survival is that, whenever a pest develops, in the course of its spread it is almost certain to run into a parasite or an antidote which ultimately restrains or overcomes the epidemic. Such was the experience with the gypsy moth and the browntail moth in Massachusetts. Even the English sparrow seems at last to have met its match in the struggle for existence. So in this matter of control wrested from the natural owners, several agencies seem to be evolving which may in time automatically operate as important checks upon its spread. One of these is the device of the so-called investment trust, and to a lesser degree the advent of the new profession of investment counsel. As for these trusts, long current in England, the result of pooling by their means the investments of many people is, of course, not only to spread the risk but at the same time to render more nearly articulate the interest of the combined shareholders. While one hundred small stockholders in the Pennsylvania Railroad or the Steel Corporation might separately have no standing in court, if they consolidated their investments through taking shares in a trust set up for the purpose, they might in the aggregate win a foothold in corporate councils. If suitably developed under proper safeguards, these concentrated investments, handled by competent persons who devote their entire time and attention to the matter, might well participate in corporate government in an intelligent and entirely helpful way. 
The professional investment trusts for profit are rapidly multiplying in numbers. Along with them are interesting developments exemplified in the creation at Columbia University of the so-called Faculty Investment Fund. This was set up in 1926 . The purpose was to create a "mutual coöperative investment group." The advantages claimed are those of the service of investment counsel; greater spread of risk; a possibly enhanced income; and relief from the physical care of securities. Three competent trustees are empowered, for suitable compensation, to handle the business. There is obviously a heavy responsibility involved for all of these professional and nonprofessional agencies. For the professional ones there is danger that the trusts themselves will be subordinated to the interest of investment banking houses. I have in mind one such with a capital of five million dollars, representing the worth of securities which will be held for the public who participate. But in this particular trust the entire control rests in the hands of Class B stockholders. This voting management is constituted solely of partners in the banking house. Other details of the technique of this establishment clearly point to the conclusion that this is substantially a device for enabling bankers to borrow money from the public at a low rate of interest, in order to finance their syndicate underwriting operations in other directions. One must expect that such abnormalities will develop out of this movement. To keep the situation wholesome, there should be a rigid separation of these investment trusts from the business of promotion or of the marketing of securities. The lack of such separation is a very real danger. The possible menace to the purely coöperative mutual plan, as exemplified at Columbia, is of professional incom- 
petence. The same possible defect attaches to another proposal of "The Inquiry": "the constitution of a socalled "Christian bloc" - a permanent committee to scrutinize investments from the ethical point of view and to arrange proxies for members when any considerable number are interested in the same concern, wherever, in fact, anything other than a merely passive participation in management seems desirable. Doubtless a way will be found by which professional skill may be so combined with proper safeguards against abuse of the delegated power. Under such circumstances a really helpful and coöperative contribution might be anticipated on behalf of the real owners.

This present tendency to strip the public shareholders of their voting rights may be checked, either through revision of our corporation laws, or by a vigorous attitude on the part of the courts. Direct action by the investing class, by boycotting all such offerings of securities, may give even more immediate results. But, in either or any event, no other safeguard against misuse of power by insiders is so likely to be effective as publicity. ${ }^{1}$ Nothing kills bacteria like sunlight. A frank sharing of all proper information with the main body of the shareholders is basically right. It is also in the long run a matter of good business. It is absurd that, as has so frequently happened of late, corporate results of operation should be given to the real owners, not every month, not even twice a year, but only superficially in an abbreviated annual report. The stockholders are entitled to know the amount of gross business, the cost of conducting it, and especially the policy as respects depreciation and upkeep in full

1 Chapters VI and VII, infra, develop this in full detail. 
detail, in order that they may benefit by the intelligent judgment which competent experts will then speedily pass upon the real status as to net earnings. The United States Steel Corporation and the American Telephone Company are forthstanding examples of the value of such frank publicity, as a recommendation to the world at large of an investment; and any corporation which pursues the opposite course thereby invites and deserves distrust and suspicion. Yet it is unfortunately true that the policy of some of the chartermongering states - Delaware, West Virginia, and the rest - has been to discourage rather than to develop such full disclosure of the state of affairs. For private corporations, the present situation as concerns stockholders' rights to information is most unsatisfactory.

Our experience with railroads is significant in this connection. They still deserve and require a greater measure of liberality in the matter of rates than has yet been granted by the Interstate Commerce Commission. But, this step once taken, they will be at last well on the road to a safe and stabilized investment for the great body of the people. It is clear already that the best of them are slowly assuming their rightful place in this regard, forging steadily ahead through the turbulence of speculation in so many other forms of enterprise. For speculation germinates in and thrives upon mystery. It is indubitable that this stabilization, even though it is yet on a subnormal plane, is largely the result of the complete publicity and standardization of railway accounts under federal supervision. Several million investors may well be content to leave the management of their railroad possessions in the hands of others, knowing that, quite apart from the regulation of rates, this standardized publicity permits a 
scientific check, month by month, upon policy and results. How different is this from the manner in which even some of our nation-wide private industrial corporations do business all over the United States, cloaked and hooded like the despicable Ku Klux Klan. The clause of the Roosevelt New York Companies Act of Ig00 which, as a penalty for failure to render detailed and current reports of operation, proposed to disqualify directors, making them ineligible for election for the period of a year, may be impracticable. Yet there may be the germ of an idea in the suggestion.

A brief address upon this subject recently, before the American Academy of Political Science, seems to have hit the crazy bone of a certain type of self-appointed spokesman of the quasi-public companies. The mere suggestion of governmental supervision, as applicable to them, in lieu of the vanishing rights of stockholders, was characterized - rather breathlessly, it seemed to me as an attack upon "all American business as honeycombed with dishonesty and greed; and all executive management as fraught with irresponsibility, indifference, and worse . . . using the traditions of a great institution of learning to spread an exaggerated impression of American business - the kind of propaganda on which demagoguery and communism feed." Their soothing allegation that a beneficent economic revolution is occurring by reason of the widespread diffusion of corporate ownership is said to be "berated and rejected with a violence of invective and an indiscriminateness in denunciation that would make a Socialist orator blush for shame." 1 Fortunately I am privileged to introduce a witness in my own defense.

1 The speaker is Henry M. Brundage, first vice-president of the Empire State Gas and Electric Association and vice-president of the Consolidated Gas Company of New York. 
The Committee on Public Securities of the Investment Bankers Association of America reported in 1923 as follows: "When administered with the broadest power, and in a judicial manner, state-wide regulation of public utilities has been conclusively proved, in the opinion of your committee, to afford the best guaranties which investors can have in this country for a maintenance of that integrity of investment necessary for a ready flow of money into the business." [Our italics present the concern of all the people - owners and consumers alike - in the matter.] For further discussion on the point, we may refer our critics to this distinguished body.

What, then, is the present status of governmental supervision over public utility companies - other than railroads, telephones, and telegraphs - in the United States? The fact is that nearly all the commonwealths have regulatory bodies, most of them, however, having jurisdiction only over such matters as rates for water, gas, and electric light and power. The present situation, therefore, as respects these operating companies is quite reassuring. What concerns the future are the hierarchies of holding companies, superposed one upon another the piling of Pelion upon Ossa to the seventh heaven. This is provocative of grave concern, for it is in the heights that the real sources of power find place. The experience of the little Boothbay Harbor company is entirely typical. But, to nail the conclusion, take the Pine Bluff, Arkansas, local operating concern. This is controlled by the Arkansas Light and Power Company, which is a part of the Southern Light and Power Company of Delaware, also controlling the Mississippi Power and Light Company, the Louisiana Power Company, and the Louisiana Power and Light Company. And the whole con- 
geries of them has been in turn acquired by the Southern Power and Light Company, this time incorporated in Maryland, which seems to be a part of the Electric Bond and Share Company of New York. Being the proud and happy possessor of some shares in this last-named corporation, I am thrilled with the sense of immediate participation in the local concerns of Pine Bluff, Arkansas! But that question has already been discussed from the point of view of the private owner. As concerns the public, it is self-evident that something besides superpower of electrical energy is entailed - and that is the growth of interstate corporations which are superpower systems of a different order. And for dealing with them we, as a people, have no machinery whatsoever.

Thus we are brought squarely to the perennial issue of federal versus state authority. Whatever is to be done about the affairs, either of private corporations dealing in the necessaries of life in more than any one state in the Union, or with, let us say, the Associated Gas and Electric Company, which supplies "electricity and/or gas and/or water, to over 300,000 consumers, serving a total population estimated at approximately 2,000,000 in more than 900 communities in New York, Pennsylvania, Maryland, Massachusetts, Connecticut, Vermont, New Hampshire, Maine, Kentucky, Tennessee, and the city of Manila," must evidently be done on a larger basis than a single commonwealth affords. (In passing we may note that this Associated Gas and Electric Company has $\$ 36,600,000$ in bonds and almost 500,000 nonvoting shares outstanding with the public. Control is apparently vested in 300,000 Class B shares, no par value.) An experiment is just now being forced upon the three states of Pennsylvania, New Jersey, and New York, concerning the 
creation of a joint giant power commission, by the growth of these great industrial units. Necessary they probably are! Sound, for aught that I know to the contrary, they are! But when one of them sprawls over the map from Aroostook County, Maine, to the Philippine Islands, it is time to think what it means. And the contention that such concerns are already thoroughly controlled or supervised in the public interest, because forsooth each of their local operating companies is subject to existing state laws, would seem to be rather effectually disposed of. This is one of those rare cases where two and two do not make four, but something well over a dozen. It is inconceivable that joint giant power commissions should be set up by different groups of states, each group corresponding to the especial scope and extent of the particular corporation which it is intended to supervise. The answer, alas, seems to be always the same. If anything indeed needs doing, there is but one agency to which to turn - the exercise of the federal power.

There are already at Washington three agencies which may conceivably become involved in these matters under discussion. But the simple, the logical, the inescapable conclusion is that superstate public utility companies should be placed under the jurisdiction, either of the Interstate Commerce Commission, as the telephone and telegraph companies along with the railroads now stand, or else under an amplified power commission, similar to the one in the Department of the Interior which at present concerns itself with the licensing of water-power companies. Whether their rates need to be, or practically can be, thus regulated is another matter. But that their accounts ought to be formally standardized and made a matter of current public record is beyond all possible question. 
What, then, about the private corporations, when direct responsibility for their management by the shareholders seems to be by way of evanescence? Whether this tendency be arrested or not, a greatly increased measure of publicity ought by all possible means to be stimulated. Standardized accounting for all private forms of business, already so successful in the case of railroads, telephones, and telegraphs, is probably hopeless of expectation. The variety of circumstance and the multifarious exigencies of each and every kind of business would present to any administrative agency a task transcending human power. And yet certain norms might well be set up by some such body as the Federal Trade Commission. To take a pressing instance: the present impasse, so far as bringing intelligent public opinion to bear upon the anthracite coal strike, might never occur again, were the recommendations of the Federal Coal Commission of 1922 respecting standardization of coal-mine accounts actually in force. The policy of what has been aptly termed "induced cost accounting" might well be elected as part of a general campaign of education by some federal body. Let us hope it will not be one possessed, as the present Federal Trade Commission seems to be, with a sole and apparently overwhelming disposition to commit hara-kiri!

A mighty and preëminently important duty is imposed upon the Federal Government by the general conditions respecting corporations which thus seem to be headed toward a climax. Whether the means for a restoration of responsibility shall be suggestively educational or strictly regulatory must depend upon circumstances. Perhaps we should revive the question of federal incorporation, so ably advocated by President Taft in his special message of I9II. This, or a federal license system 


\section{II6 MAIN STREET AND WALL STREET}

whereby permission to engage in interstate commerce entails compliance with certain standards as to corporate structure and publicity, deserves attentive consideration. The report of the committee of the British Ministry of Reconstruction of I9II, ${ }^{1}$ dealing more specifically with trade associations than with corporations, was a response to somewhat the same great need which is making itself felt at this time in the United States.

I would not conclude with the advocacy of any particular plan. The first duty is to face the fact that there is something the matter. For a remedy I am groping as yet, like a child in the dark. I am conscious that things are not right. The house is not falling down - no fear of that! But there are queer little noises about, as of rats in the wall, or of borers in the timbers. I believe that the trouble has to do with the growing dissociation of ownership of property from responsibility for the manner in which it shall be put to use. And now is the time for action. It is not yet too late. Millions of our citizens made this first essay in thrift as a result of the great Liberty Loan campaigns during the war. It has been estimated that of the $14,400,000$ stockholders in the United States no fewer than $3,400,000$ were added within the three years following I9I7. This betokens a great incursion into the field of investment by the common people - corporate possession being shared by those of moderate and small means with the wealthy class. The movement has been called "an economic revolution" "the passing of ownership from Wall Street to Main Street." What would be the effect were these newcomers - consumers, employees, or others - to discover some

1 This standard British Blue Book can be obtained through the British Library of Information, 44 Whitehall Street, New York City. 
day that ownership and control had parted company, each going its way as ships that pass in the night? Suppose that the ownership of many industrial plants, great and small, continues to reside all through the countryside, but that the lodgment of the power of direction has shifted to the great financial centres. We have had experience, to our sorrow, with the old sectional divisions between the East and the West. Is there no smouldering spark in this matter of corporate control, which may some day flare up as a political issue of the first order? I do not look to Sentinels of the Republic or to antisyndicalist laws for the ultimate safeguarding of our institutions. Our security, in the last instance, must rest upon the ever-wider prevalence of what Lord Bacon held to be "clear and round dealing among men!"' With that assured, we may quite confidently leave all the rest to take care of itself. 


\section{$\mathrm{V}$ \\ NEW THOROUGHFARES}

\section{A WAY OUT?}

Catalysis, says R. Kennedy Duncan in his New Knowledge, is as old as drunkenness. It is also responsible for most drunkenness. For it is merely yeast, in contact with sugar, which, by its presence, disintegrates the sugar into alcohol and carbonic acid. So also a tiny lump of platinum sponge at the jet of a street gas-lamp by its mere presence so speeds up the reaction between oxygen in the air and the gas as to become incandescent and to ignite the compound. Such are the properties of catalytic agents. It is their mere presence at the right time, given a proper combination of circumstances, which sets everything going. Deadlocks go by the board, as if by an explosion. So it is, sometimes, in human affairs. Matters almost but not quite reach a head. And then suddenly, under a seemingly insignificant impulse, great underlying forces are released. Things happen. Thus it was, when, during the winter of $1925-26$, a ten-minute academic deliverance of mine, concerning the strong disposition among bankers financing great enterprises to disfranchise the public shareholders, arrogating to themselves all place and power in management, touched off a considerable to-do.

The first outcome of the evident public interest in this matter was the chapter which immediately precedes this one. And since that time, now nearly a year ago, a 
never-ending stream of discussion has poured forth. One of the latest utterances, a really pointed contribution, was that of President Sloan of the General Motors Company in the World's Work for October, 1926. It is quite evident that momentous issues which reach down into the bowels of American business are concerned in this debate. So much interest betokens the presence of a considerable disquiet deep down beneath the surface. It indicates that matters are involved which concern not only the vitality of American industry but the very foundations of our civilization, built as it is upon the bed rock of private possession of property. One certain result of this general debate has been the almost unanimous condemnation of all those devices which are intended to wrest from the common shareholder his traditional right to participate by voting in the conduct of the businesses in which he may happen to have a proprietary interest. How far matters have already progressed may be gathered from the statement that of $\$ 1,500,000,000$ of publicly held securities of twelve major holding companies serving electric light, power, gas, and water in the United States in 1925, the equity common stocks, in which are vested the complete control, amount to only ten per cent of that stupendous total. In other words, a ten-per-cent ownership, most of which cost the present owners not a penny, carries control of the entire remaining nine tenths of the participation. That is indeed a long stride away from the age-old Anglo-Saxon practice of the right of the majority to rule.

So much for water which has gone over the dam. But the disfranchisement of public shareholders in the years to come is dead - dead beyond recall. The practice has already been crushed beneath an overwhelming weight 
of public opinion, finding its expression with almost dramatic suddenness through a succession of events of unusual moment. First came the action of the governors of the New York Stock Exchange. They announced approval of a resolution of their Committee on Stock List that it would take instant cognizance of this matter of disfranchisement. "Without at this time attempting to formulate a definite policy, attention should be drawn to the fact that in the future the committee in considering applications for the listing of securities will give careful thought to the matter of voting control." Shortly thereafter the Interstate Commerce Commission disapproved of the proposed Nickel Plate merger, foremost among trunk-line consolidations, in these words: "We believe it to be self-evident that the public interest requires that the entire body of the stockholders of a railroad . . . and not a powerful few, shall be responsible for its management." The same view was subsequently expressed in connection with the Pittsburgh and West Virginia application. Then in the Bank of North America case, a voting trust, typical of a widespread practice among the great financial institutions which effectively disfranchise their shareholders, was set aside by the courts as contrary to public policy. "The invalidity lies not in their motive but in the device itself. It essentially lends itself to improper conduct of a quasi-public institution." Bills and resolutions were offered in the houses of Congress and in several state legislatures. Among administrative bodies, the New Jersey Public Utility Commission refused approval of security issues, even despite express sanction of disfranchisement of shareholders under the state corporation law. "The power to control the management of public utility corporations should be in the 
hands of their stockholders." Quite without governmental or even stock-exchange pressure a considerable number of corporations went so far as to revamp their entire financial set-ups in response to this overwhelming consensus of opinion.

The capsheaf of public condemnation, following a number of months of vacillation and debate, was laid by the committee on industrial securities of the Investment Bankers Association of America. "Weighing the above arguments for and against the issue of nonvoting common stocks, your committee is of the opinion ... that . . major considerations of public welfare require that nonvoting common stocks be not issued." Only under certain conditions with especial restrictions was this general ban to be lifted. A highly conservative and respectable body this. And there were innumerable editorials in the press from all over. There were cartoons. Top-notch literature broke through from prose into poetry - in "The Conning Tower" of the New York World, "On Waiting in Vain for the New Masses to Denounce Nonvoting Stocks."

Then you who drive the fractious nail,

And you who lay the heavy rail, And all who bear the dinner pail And daily punch the clock Shall it be said your hearts are stone? They are your brethren and they groan! Oh, drop a tear for those who own

Nonvoting corporate stock.

The author of this book even got an unsolicited invitation to the annual dinner of the Gridiron Club at Washington - setting the seal of newspaper notoriety upon him. Such immediate and well-nigh unanimous response 
to but a slight stimulus is perhaps unique in our economic annals. There must have been a convincing warrant for the public disapproval to have provoked it all so instantaneously. Nonvoting common stock, then, bears every. appearance of being dead - dead beyond recall.

Nailing the common stockholders to the saddle by force of public opinion is, however, only half the story. What about the holders of preferred shares? Are they to be ditched with impunity? Their unseating has, all of a sudden, assumed a peculiar importance by reason of the lusty development of the electric light and power industry. The issue has unexpectedly become as vital with respect to preferred as to common stock. Substantial authority exists for the contention that investors, having a prior claim upon both earnings and assets, may be safely eliminated from any participation in management, so secure is their proprietary status. ${ }^{1}$ The Industrial Securities Committee of the Investment Bankers Association of America, in I926, in finally condemning disfranchisement of common shareholders, still holds to the view that the widespread limitation of voting rights for holders of preferred stock, restricting their power of intervention to the event of nonpayment of dividends for a stated period, was on the whole justifiable. The argument rests upon the view that the preferred claim upon earnings sets off this group, somewhat as bondholders are treated; so that they may rightfully be called upon to renounce their participation in management in return for the advantage of security which they possess. This may once have been true. But in view of the charter-drawing

1 Such is the conclusion of W. H. S. Stevens, 2uarterly Fournal of Economics, May I 926 , after a very exhaustive examination of some 350 corporate charter provisions. On the law, consult A. A. Berle, Jr., Harvard Law Review, April I926. 
practices which have become prevalent nowadays, as set forth in detail in our preceding chapters, an increasing doubt as to the soundness of this contention may be registered. Not quite so recent as those against common shareholders, the limitations placed upon preferred stocks are nevertheless distinctly modern. And they run contrary to the sound principle which comes down to us through a long history, that all shareholders alike are partners in corporate enterprise. The solution of our present problem should come, as it seems to me, rather through a complete reversal of the present trend than through its accentuation. There should not be a narrowing of the franchise. The tendency should be quite the other way. The preferred shareholders and perhaps even the bondholders as well ought to participate in government more than they do. For, as things work out practically, neither of them may with safety stand quiescent on the side while conditions are created which are bound ultimately to jeopardize their rights. There would be far greater safety all round were they, perhaps not with a hand on the throttle but at least with a seat in the cab, always in position to exercise a wholesome check upon definite commitments as to policy.

The great danger attendant upon disfranchisement even of preferred shareholders is best illustrated by the situation which is rapidly being created in the field of electric light and power. This will be subsequently set forth in detail in the chapters on the subject. The net result thus far has just been stated, however, at the head of this chapter, outlining a condition of affairs wherein the entire control of $\$ 1,500,000,000$ of public investment in electric light, power, gas, and water companies resides in only ten per cent of its capitalization. The mechanics of it is simple. 
For in the setting-up of these great public utility holding companies, piled one on another, it is the preferred shares alone which are sold to the public in order to provide the necessary capital. The common shares are strictly held within the management - such shares constituting the nexus, binding one to another throughout from top to bottom. Under these circumstances the common shares are devoted to government. The preferred shares theoretically have a first claim upon income. Could it be true that the preference as to income could be dissociated from all the other privileges, voting and the like, one might possibly consent to the substitution of security for the franchise. But the fact is, as already set forth in the preceding chapter, that all sorts of preferences in the matter of government, control over new issues, relative priorities and the like, quite apart from income preference, may be attached to the common shares. The mere provisions as to income preference may read fairly enough on their face; but if the management through ownership of the sole voting common shares has the right to issue new securities ad lib. as well as to slip them in anywhere ahead of the existing preferred shares, perhaps even to retire the preferred shares altogether, or to buy and sell corporations, to transform alliances, - in short, to do almost anything under the sun, - mere preferences as to income may turn out indeed to be but hollow mockeries. The whole corporate structure, in brief, from top to bottom is so involved that one may never be sure in pulling at a thread how far the wrinkles in the entire fabric may spread.

Contest in 1926 concerning a change in the capitalization of the American Light and Traction Company contains food for thought as respects disfranchisement of 
preferred shareholders. Holders of 6 per cent preferred stock, carrying voting rights, were invited to exchange it for an equal amount of $61 / 2$ per cent prior preferred shares. This was proposed by the management as "highly advisable," to "improve the Company's situation and enable it to more favorably finance its affairs." No particular mention was made of the elimination of the voting power. Such indeed is the process by which the magician extracts rabbits from empty hats. Now the certificate of incorporation reads as follows: -

The Holders of the Prior Preference Stock shall have no voting powers nor shall they be entitled to notice of any meeting of stockholders of the corporation, except for those purposes, if any, for which said powers and notice cannot be denied or waived under the laws of the State of New Jersey, unless and until there shall be default in the payment of two (2) quarterly dividends thereon.

Is this not an extraordinary denial, which includes even the right to notice of meetings of other stockholders? Just suppose there were other clauses of the charter - as a matter of fact I do not know whether there are or not in this particular case - which give power to the common shareholders without let or hindrance to issue new shares of any sort at their option, and even to create new preferred issues which should take priority over those in existence, as well, of course, as to retire this proposed issue at will. In this particular instance about 30 per cent of the common stock was controlled by two management concerns, the Koppers Company and the United Light and Power Company; and Koppers and Company and Otis and Company of Cleveland owned substantially all of the voting shares of the United Light and Power Company. The result was that with this disfranchisement 
of the preferred shares - selling a birthright for a mess of pottage - the entire control would have been pocketed by a small inside group. The plan was blocked by discovery of the impending disfranchisement in time to register the dissent of more than one third of the issued and outstanding preferred stock, thus preventing approval by the necessary two thirds, as called for by the preexisting charter. The instance is quite typical of a common practice.

There is also an interrelation between the federal income tax law and the tendency toward disfranchisement of preferred shareholders by the public utility companies which deserves attention. In these complicated combinations under interstate holding corporations some subsidiaries may be operating profitably while others are running at a loss. It is highly desirable to be able to set off the debits against the credits. Otherwise, taxes must be paid upon the gains without any abatement for the other companies which are in the red. But the federal income tax law reads that consolidated income statements may include only those subsidiaries of which 95 per cent or more of the voting stock is owned by the top corporation. Obviously in the desire to secure all of the abatement of taxes possible, a heavy incentive is hereby offered to place as many subsidiaries as possible in the class of 95 per cent control. It is equally obvious that by the disfranchisement of the preferred shareholders a holding corporation might control a subsidiary by even a minority ownership of its stock, provided that the holding corporation owned only common shares, and that the voting power of all other classes of stock had been eliminated. This motive of tax abatement strongly accentuates the natural tendency of managers to entrench themselves 
in power by elimination of the voting rights of the public. It is the combination of both motives at the present time which is so strikingly forcing the public right, title, and interest into the background. Amendment of the federal law may be necessary to restore the public to its proper place.

All sorts of other conflicts of interest between different groups of security holders are bound to arise in a complicated financial set-up, besides those concerning merely priority of claim upon earnings. ${ }^{1}$ Banking or management control usually entrenches itself through possession of a majority at least of the common stock. To the public is assigned the ownership of the bonds or of the preferred shares upon the rightful ground, perhaps, that these are safer investments. But unless careful safeguards are provided in the charter, as has already been amply illustrated, a menace to these prior claims upon income may arise from intrusion of new securities ahead of the preferred shares. Or, equally important, an ultraconservative policy in withholding the payment of noncumulative preferred dividends may be adopted, thereby building up the equity behind the common shares in the hands of the management. I have in mind a considerable business in which the bankers, that is to say, the management, have a predominant interest in the common stock, the public holding a major interest in the preferred shares. Something like 40 per cent of unpaid dividends has accumulated on the preferred shares despite the earnings quite adequate for resumption of these payments. But the building up of the equity behind the common shares continues, while the helpless public investors, having no voting power, must sit by with folded hands. These are ${ }^{1}$ Cf. Ripley, Railroads: Finance and Organization, pp. 100 et seq. 
the dangers with which one may counter the hackneyed argument that at bottom managements and public shareholders have an entire unity of interest in the welfare of the concern; from which it follows of course that the motive of self-interest on the part of the voting shares may safely be depended upon to safeguard the rights and interest of the others. The answer in brief is that it is not so, as proved by long and bitter experience.

In many ways the Pujo Senate Committee Report of I9I 3 was a prophetic utterance. There is one passage in it which so aptly describes present conditions that it deserves resurrection.

The situation that exists with respect to the control of the so-called mutual (insurance) companies is in a modified way illustrative of all great corporations with numerous and widely scattered stockholders. The management is virtually selfperpetuating and is able, through the power of patronage, the indifference of stockholders, and other influences, to control a majority of the stock. This means that, where representatives of a great banking house are on the board and are financing the corporation and in close relations with the management, the policy of the corporation is largely determined by the bankers where they choose to assume that responsibility. They may name the officers and directors and they buy and sell their securities without competition on terms that they think fair. The effect of such a system manifestly assures to the bankers a relation that they should not bear any power that they are not entitled to wield over other people's money and property in the determination of questions and policies as to which they sit on both sides of the table.

It is such conditions as these, then, which induce the conclusion that disfranchisement of any class of stock, preferred or common, is inadvisable. But, thus far, it is a fact that only the nonvoting common stocks appear to be moribund. 
The King is dead! Long live the King! But nonvoting common stock, at least, being dead, to whom shall the succession run? What next? It is not a time to mourn over the demise of a fellow citizen who was no better than he ought to be; nor is it a time for preoccupation over selfish details of heirship. It is an occasion, while our minds are bent upon it, to take serious counsel for the future. This wholesale condemnation of the practice of disfranchising shareholders, the only defense for which was that it concentrates responsibility (although exclusively in the hands of banker management), is certainly not to be interpreted as a repudiation of the soundness of the principle, wholesome both in government and private business, expressed by this defense. In the course of the discussion there has been widespread misunderstanding of my own position as to this. All parties agree that any plan for the greater democratization of corporate management which is based upon the expectation of a general active participation by the whole body of shareholders is bound to go wrong from the crossing of the wire. That is why town-meeting government had to yield place to organization as a municipal corporation. So-called bank or management control represents an extreme on the one side as undesirable as attempted mob rule or town-meeting administration would be on the other. The average stockholder is entirely unqualified to engage actively in management. For a surprisingly large number of great corporations more than half of the shareholders are women - in American Telephone for 1926, 200,000 of the 366,000 were on the distaff side. Such a multitude are ill-fitted by training - begging the moot point of sex - to govern directly, less so than in politics. These business issues 
are far less simple, far less moral, and they make less appeal to the imagination than those in the field of government. Even the men by themselves, for the most part, have neither time, impulse, nor capacity for such concerns. The very practice of scattering investments, spreading the risk, would in a considerable estate constitute an aggregate burden of bother which would be backbreaking. The problem therefore is to devise something within the range of shareholders' probable capacity which shall point toward, even if it does not attain, the desired end of a reasonable check and balance upon management. In other words, it is a question of devising something as respects the management of property analogous to the system which the fathers of the American constitution sought to introduce into our scheme of political government.

The real significance of the episode of nonvoting common stock was that it uncovered a body of doubt and misgiving as to the state of our corporate affairs, which has been accumulating for many years. Our first chapter, embodying the views of President Wilson as expressed at the American Bar Association meeting in I9IO, presented clear evidence as to this. Contentions of first-class importance come to a head at the point of contact of management and ownership. If the common sense of the people be opposed to shareholders' abdication, what is their status to be in the future? The fact of their ineptitude at present offered the main warrant, so far as there was one, for this recent abortive attempt to make them wards in chancery. Yet it is equally certain that they cannot take the saddle. Efficiency of American industrial management for purposes of production is justly a source of national pride. This con- 
centrated power and responsibility in performance can no more be expected to abdicate than can the great body of shareholders. And we cannot simply leave the matter to the courts for settlement, for litigation merely closes the stable door after the horse has been stolen. There must somewhere be a middle ground of division of function - a normal domain of managerial responsibility and yet another of shareholders' participation. A farseeing younger member of the New York Bar, A. A. Berle, Jr., has succinctly stated the issue:-

We are now faced with the question of securing on the one hand the benefits of continuous, compact, and able direction, and of avoiding on the other the hazard of unchecked power, whose strength is used in its own, rather than in the corporate and public interest.

The prime fact confronting us as a nation is the progressive diffusion of ownership on the one hand and of the ever-increasing concentration of managerial power on the other. Little personal enterprises pass almost imperceptibly over into great formless aggregations in which what is everybody's business threatens to become nobody's business. The president of General Motors in the October World's Work states the danger when he says that "there is a point beyond which diffusion of stock ownership must enfeeble the corporation by depriving it of virile interest in management upon the part of some one man or group of men to whom its success is a matter of personal and vital interest. And conversely at that same point the public interest becomes involved when the public can no longer locate some tangible personality within the ownership which it may hold responsible for the corporation's conduct." General Motors is peculiarly fortunate, however, in that, along with a 
40 per cent ownership of stock by 70,000 people, there is a 60 per cent concentrated ownership in a small group, almost, one may say, in the DuPont family. But this ideal situation - under which the DuPonts, with their unusual technical training and ability and their innate sense of trusteeship, stand sponsors for success through having the major property stake in success or failure represents unfortunately only a transitional stage in development. When this generation passes on its way, will that guarantee for continued success be possible of continuance? Or will the concern go the way of thousands of others? Will the business become so loosely and so generally owned that no small knot of people whatsoever have even an appreciable share of the total ownership? American Telephone, General Electric, the old express companies, most of our railways as well as industrial corporations, are like this. And most pathetic of all are those which lumber along in the doldrums, forsaken by their former sponsors, even as everybody deserted the old New Haven Railroad, and more recently the poor old Chicago, Milwaukee and St. Paul. And the more such a concern is in need of friends the less dependence can be placed upon anybody in particular. If we would avoid serious consequences in the way of public revolt some day, it is incumbent upon us as a nation, I am convinced, to discover some way out of this deadlock.

The most thought-provoking remedy suggested for dealing with this matter is the institution of some permanent agency in place of the not unusual temporary agencies now existent, which shall be more immediately representative of the shareholder's right, title, and interest than the existing machinery; and which shall promise a fair chance of awakening sufficient interest 
among the electorate to induce at least an intelligent minority to take part. For it will be the participation of such an intelligent minority which, as in the field of politics, makes democracy tolerable. Such a body, either created out of hand or else evolved from present boards of directors, might be expressly empowered in the charter to assume certain responsibilities and to perform certain functions by way of check-up, so to speak. Its primary function would have to do with adequate publicity through independent audit. The assumption of other duties might thereafter take place, as we shall see, as a matter of course. Searchlights from several different directions have converged upon this matter, rather sharply, to define it as a possible remedy. Two competent younger members of the New York Bar ${ }^{1}$ have independently proposed, for large concerns which have attained a clear status of widely diffused public ownership, the creation of such permanent committees, representative exclusively of shareholders' interests. These bodies are intended to serve as continuing independent checks or balances alongside the customary executive organization, not however dividing responsibility in any sense of the word, but merely tying in that responsibility for management with the main body of the owners. A peculiar stimulus has just been given to this proposal by the Accountants Association of America. At its last convention - as a direct outcome of this general campaign of education, be it said - the Accountants Association went on record in favor of the adoption of the

1 Eustace Seligman, Esq., of Sullivan and Cromwell, American Bar Association Proceedings, September 1923; and A. A. Berle, Jr., Harvard Business Review, April 1926. Compare also conclusions of the National Civic Federation Conference on Trusts and Combinations, urging the adoption of German precedents of a similar nature; and Steinitzer, Ökonomische Theorie der Gesellschaften, Leipzig, 1908. 
independent audit as it has been in effect in Great Britain for many years. The proposal, however, standing by itself would be unworkable under our American conditions. To become practicable, it calls for just the institution of a permanent shareholders' representation which has been outlined above. In Great Britain the profession of Certified Public Accounting is standardized upon a high plane by statute which prescribes qualifications and performance. Auditors largely stand upon their own feet, assured of a high standard of excellence. But with us, with the credentials of competence emanating from forty-eight conflicting and competing state legislatures, sheer independent audit would be no better than management audit as we have it at the present time. At this writing only seven states have legislated at all as respects accountancy. Two of these seven statutes have already been declared unconstitutional. There can be no hope from the independent audit under such circumstances unless and until it be tied in with the positive creation of some body independent of management to which the auditor shall be accountable.

Nor is this proposal a novel one. It was made several years ago by the Railway Age Gazette for the better government of railroads, in the suggestion of a permanent instead of, as sometimes happens, a temporary twoparty system in railroad directorates. We are quite familiar with such agencies, set up to cope with an emergency. This proposal is an attempt to insure a sustained interest in such bodies. The need of it at the moment is especially great in the public utility field. "Merciless publicity" is the remedy commended by experts in that business. ". . . and the only way to secure it is to have a man or group of men who are entirely disinterested 
sitting in on [directors'] deliberations but having no voice in their determinations. Suppose there were organized the 'Corporate Fiduciary Council, Incorporated,' made up of men of undisputed integrity, employing for their use as representatives such men as certified public accountants, lawyers (not counsel for the corporation), and trust officers of trust companies." This idea impinges of course upon the proposal that such persons, sitting in, should be of the nature of public directors nominated by a governmental board - let us say, not to give offense, analogous to the Federal Trade Commission.

Lest this plan be deemed fanciful, moreover, - or no better than what we have now, - it should be noted that an actual experiment in this direction is in process of trial by the Dennison Manufacturing Company, of Framingham, Massachusetts. A pioneer already in the development of management ownership, or, as they call it, "incorporated partnership," it is now proposed, lest the public owners be consigned entirely to outer darkness, to introduce a constitutional nexus between ownership and management through such a check-up committee. The gist of this idea is in fact embodied in the insistence by President Sloan of the General Motors, in the October World's Work, upon the need of "some tangible personality [our italics] within the ownership which it [the publicshareholder group] may hold responsible." Where, as in General Motors, there are DuPonts; where, as in Great Northern, there is a James J. Hill, or, as in United States Steel, Judge Gary, well and good. But where there are no such dominant owner-managers, the next best makeshift is sought - not nearly so good, but better than nothing. Another analogy would be to the supercargo 


\section{I36 MAIN STREET AND WALL STREET}

in our good old shipping days. He was n't supposed to navigate the vessel; he was a landlubber, generally seasick the first part of the voyage. Perhaps he was not even to assume charge of the trading on shore. But wherever the ship went, there went he also. It was his business to keep a vigilant eye upon whatever took place; thereafter his function ceased.

The novelty about this project for stockholder representation consists merely in the constitution of a continuing body instead of a temporary or emergency one, and - this being of the utmost importance - its creation not to cope with a management in terms of conflict but to recognize that full responsibility and authority are still vested in the directorate, subject only to the condition that there shall be a reasonable amount of disclosure and consultation precedent to action. Note within the current year how, almost automatically, bodies of this sort have sprung up in cases of emergency. In Cleveland there is the "Committee of the Common Stockholders" of the Goodyear Tire and Rubber Company; the "Bondholders Defense Committee," set up with reference to the reorganization plans of the Chicago, Milwaukee and St. Paul Railroad; and in another domain the "Protective Committee" recently created to deal with the collapse of G. L. Miller and Company, Incorporated - first of the top-heavy real-estate investment concerns to disclose its structural weakness. One might thus compile a long list within the current year of evidences of such responsiveness on the part of corporate shareholders under the particular stimulus of an emergency. Most of these owe their initiative either to banking houses which have participated in the financing, or else to legal concerns not altogether blind perhaps to the 
emoluments of office. But these temporary expedients have arisen without the slightest encouragement from the charters of the companies concerned - often in the face of bitter opposition even to access to the list of stockholders and the accounts. Surely, with full provision in the charter whereby adequate machinery might be set in motion, together with the provision of funds from the corporate treasury to meet the attendant expense; and, most of all, in view of the certain advantages accruing to the management itself in case of such coöperative action, the chances of success would seem to be good enough to make it worth while to try the experiment.

The parallel between the post-war situation in the field of labor and that of ownership and management of corporations is striking. The following excerpt from President Wilson's Mediation Commission, substitution being made of "shareholder" for "employees," is directly in point. "Broadly speaking, American industry lacks a healthy basis of relationship between management and men. At bottom this is due to the insistence by employers upon individual dealings with their men. Direct dealings with employees' organizations is still the minority rule in the United States. . . . The leaders in industry must go further; they must help correct the state of mind on the part of labor; they must aim for the release of normal feelings by enabling labor to take its place as a coöperator in the industrial enterprise. In a word, a conscious attempt must be made to generate a new spirit in industry." The tangible result in the domain of labor has been the introduction of employee investment, of the company union, and even of labor membership on the boards of management - as witness Procter and Gamble Company, for instance. If it be deemed wise thus to 
extend a hand of fellowship to labor, why not try the same experiment with respect to the great body of the owners?

Why might not such a representative shareholders' body be evolved out of the existing machinery? It will be said perhaps that something like this separation between executive activity and shareholders' representation already exists to a certain degree within the directorate of many large corporations. Real governing authority is vested in an executive committee which keeps closely in touch with the staff which does the work, and this committee is responsible of course for details in matters of policy, although not for mere execution. Outside this group, composing the balance of the directorate, is a majority probably made up of persons who more or less perfunctorily attend but who at least are constantly advised as to what is going on and who are summoned into action in matters of a controversial sort. Ordinarily their minds are not attuned to details, but they stand or rather sit on the side lines as informed and more or less expert onlookers. The larger the board at present the more apt is this separation of function to occur. The plan herein proposed might well assume the form of a further concentration of direct authority and responsibility in an executive committee, the small board of persons who really give their minds to the business incidentally being paid, as they should be, for the amount of time and energy consumed; while the inert directors, under the present system, are relegated, not to outer darkness, but to a penumbral state which they have power to illuminate at any time in case of need. But even this outside body, which should correspond to our representation or check-up committee, would of necessity be more thoroughly divorced from the inner circle 
than it is customarily at the present time. Most of these present attachés, dummy directors, or what you will, are actually put there and ${ }^{*} k e p t$ there by the inner circle, knowing the master's voice and acting harmoniously therewith. It is of the essence of this new proposal that this outer group should, so far as is possible, be independent of and serve as a check upon the inner group. The present theory is that the general board springs from the shareholders and that it merely delegates its functions to an executive committee. And this is true for many corporations where the by-laws require a reference to the general board and a validation vote. But the additional common rule that the executive committee may function with quite full responsibility in lieu of the directorate puts another face upon the matter. And this tendency is strongly marked in the latest type of banker-management charter drafting. The new idea, in distinction to the old one that the executive committee is the board of directors in little, is supplanted by emphasis upon the theory that each of the two derives from the same common source, the main body of the shareholders. One of these, however, receives a delegation of power to manage, the other is endowed with authority to exert a check upon the exercise of that directorial power.

Adequate precedent exists for the payment from the corporate treasury of expenses, including salaries, of such a representation committee. It is not at all uncommon after closing a contest for control or in respect of reorganization, let us say, for an allowance to be made from the company treasury to meet the expenses of the minority. Some $\$ 30,000$, for instance, was allotted to the minority party at the time of the Rock Island Railway reorganization in 1917; and the recent Goodyear 


\section{I4O MAIN STREET AND WALL STREET}

Tire and Rubber reorganization in $192 \mathrm{I}$ arranged for payment of voting trustees in similar fashion. There is nothing unusual, in fact, about the proposal which would stand in the way of laying such a charge for the maintenance of a permanent stockholders' organization upon the shoulders of the corporate treasury.

The most important activity of a shareholders' supervisory council would have to do with independent auditing of accounts. In the next chapter, which will take up adequate information - that is to say, publicity as a general remedy for corporate transgressions - this matter will be appropriately discussed under that heading. The English law affords an admirable precedent for cooperative endeavor. The first auditors are appointed by the directors; but after the first statutory meeting they are elected annually by the shareholders, and in default of such appointment the Board of Trade may appoint the auditors upon application of shareholders. In practice, to be sure, the auditors are selected by the directors in most cases as things have worked out. With this matter we must deal in due course. Such independent audit under the Companies Acts has been for many years compulsory. Auditors share with the directors responsibility for the accounts as published; and auditors have been held liable for damages, even to the extent of criminal prosecution, for indirect participation in the issue of false accounts. The law reads as follows:-

Every auditor of a company shall have a right of access at all times to the books and accounts and vouchers of the company, and shall be entitled to require from the directors and officers of the company such information and explanation as may be necessary for the performance of the duties of the auditors. 
It is provided furthermore that auditors shall report to shareholders on every balance sheet laid before the shareholders' meeting during their term of office, stating whether they have had full access to sources of information and whether the balance sheet exhibits a true and correct view of the company's affairs. The law makes it a misdemeanor to circulate unaudited balance sheets, not accompanied by a copy of the prescribed auditor's report. The law even contains the proviso that, to assure their independent status, there shall be no change in personnel of the auditors, elected as above stated, at the annual shareholders' meeting, without due notice in advance of intention to nominate a new auditor. Each shareholder as well as the retiring auditor must be notified. The intention of this is to meet the contingency of conflict between the independent auditors and the management, so that the shareholders may meet the situation intelligently. A recent White Paper by a committee of the Board of Trade, reporting on this feature of the law, confirms the impression as to its satisfactory effect.

As regards the adoption of the independent audit in the United States, several modifications of the English practice commend themselves. The proposal of a duly chosen shareholders' representation committee implies that it should name the auditor and that he should serve under its supervision, and be accountable to it for his work. Under the English practice the auditor as a certified public accountant stands upon his own feet independent of both other parties to the affair. Another plan might be, as hereinafter suggested, that the Federal Trade Commission or some other prominent governmental agency should have jurisdiction over all such 
matters, so far as interstate commerce is concerned, even as Federal examiners periodically inspect the accounts of national banks. It would be requisite, however, that the supervisory authority at Washington should be as competent and endowed with as great powers as now obtain in the field of national banking. Failing such legislation, the shareholders' representation committee might well function more actively than the general body of British shareholders appears to do. Unless and until, at all events, the independent status of the profession of accountancy in America be affirmed at law, the somewhat inarticulate British practice, standing by itself, would fall short of a full measure of efficiency in this country.

The British practice as to independent audit is confined entirely to the balance sheet, which, as outlined in the next chapter, affords merely a picture of the state of affairs as of a given date. There is in England no independent audit of the income account. And it is the income account which is the more important of the two. Transplantation of the British practice to the United States should include an independent audit, covering income as well as balance sheet. The proper limits for publicity of the income account, especially in highly competitive industries, would doubtless vary from one business to another; and it might be necessary to afford some protection to managements against undue disclosure, temporarily at least, of the state of affairs even to the shareholders' committee. The unfortunate consequences of a "leak" in a critical situation or in case of unwarranted attack by speculators are obvious. And then it appears that the British auditor is somewhat circumscribed in activity as respects information obtainable outside of the books and records of the concern. In this 
regard, even under our prevailing American practice of subserviency of the audit to managements, it is the practice for our auditors to go further afield than the mere books and accounts for verification. Thus the open accounts of clients are customarily circularized by bank examiners. Unless the responsibility for independent audit under the new conditions retained this feature, adoption of the British practice would mark a step backward rather than forward. With these qualifications, how great would be the advantage of general acceptance of the principle laid down in the English case of Leeds Estate Building and Investment Society, Limited, vs. Shepard:-

That it was the duty of the auditor in verifying the accounts of the company not to confine himself to verifying the mathematical accuracy of the balance sheet, but to inquire into its special accuracy, and ascertain if it contained the particulars specified in the articles of association and was properly drawn up to contain a true and accurate representation of the company's affairs.

A somewhat similar practice obtains in Japan. Under the prevailing law, corporations - the Toho Electric Power Company, Limited, for example - are compelled to render semiannual statements in connection with the payment of dividends. They are not allowed to publish these reports, however, until they have been submitted to a committee of the stockholders, no member of this committee being an officer of the company. And a definite legal liability is imposed upon those who are responsible for any misstatements which may occur therein.

The practicability of a wider development of this British practice, making the shareholders' participation a positive force instead of, as in England, rather a mere 
matter of form, depends largely upon compliance with a fundamental rule in human relations. It is a poor rule that does not work both ways. It is a poor bargain which does not advantage both buyer and seller. No such innovation would amount to a hill of beans without the active and sympathetic coöperation of the management. Such a shareholders' representation could not be injected into a corporate situation by main force. There would be ways a-plenty to kill it, or to capture it a-borning. One must discover means by which such an organization, while helpful to the shareholders, would at the same time be in position to contribute something constructively in aid of the management. It is submitted, therefore, at this point that there are at least three such functions, in respect to which managements might gain substantial aid and comfort from the existence of such a body directly representative of the shareholders. These three functions concern, first, the raising of funds through stock subscriptions; then proxies and the validation of particular transactions; and, most important of all, protection against legal liability of directors for untoward consequences of their acts.

As to the raising of funds for improvement or extension through subscription to capital stock, managements are frequently embarrassed by the vacillation or indisposition of isolated small stockholders to participate. They hesitate between selling their rights or taking up the subscription. An urgent appeal from the management itself in case of slight distrust is naturally unconvincing. Is there not a chance that a hearty endorsement from an independent yet thoroughly informed shareholder source might tip the scales in the aggregate mind of the stockholder body in favor of the management 
programme? It might even obviate the necessity of a bankers' underwriting, with an attendant economy which in itself would more than pay the cost of maintenance of such a committee.

The routine conduct of corporate meetings, reelection of directors, and the like, with successful corporations, is for the management of a large concern usually a matter of form. The presence and participation of shareholders directly in such corporations has of course become a thing of the past, although in a small country like England these meetings are still of some importance. A calm-weather piece of business, for example, is the accumulation of enough proxies merely to reelect a board of directors. For, be it efficient, or at least not demonstrably incompetent, things go through as a matter of course; but it is still necessary to register a majority of the outstanding shares. This in the case of non-dividend stocks, however, is not so simple as it appears. For many of the owners have deposited these evidences of disappointed expectation at the bottom of the box, hoping against hope, and meanwhile declining to concern themselves further about it. Under such circumstances, as already described, it may be necessary for the management to pass the hat about in the financial district, soliciting enough proxies from the floating stock in the street to assure a quorum. A logrolling procedure is thereby set up. House A grants, solely as a matter of courtesy, the request of House B for proxies of voting shares in Company $\mathrm{X}$. House $\mathrm{B}$ reciprocates in kind with reference to Company $\mathrm{Y}$. Thus does the existing management fulfill the necessary quota. And $\mathrm{Y}$ perpetuates itself in the saddle also as a matter of course.

It is when the corporate vessel runs into roiled water, 


\section{I46 MAIN STREET AND WALL STREET}

when novel circumstances present themselves for action, that the handling of shareholders' proxies becomes particularly bothersome. Suppose, as required by law, that particular transactions must be validated by vote - the authorization of a sale of assets, approval of a lease, validation of the issue of new securities, or a mortgage. The form of proxy must necessarily be complex, specifically legal to the last detail. The natural instinct of the normal individual is to refuse to sign anything which is not understandable. The utmost difficulty in management is experienced in such matters, particularly among the public utilities with their host of small, inexperienced, and consequently timid shareholders. The experiment is said to have been tried of even attaching a coupon validation to dividend checks, whereby approval should automatically ensue upon return of the cancelled check, should the shareholder not bestir himself sufficiently to tear off the coupon before cashing in. A decidedly risky expedient! New Jersey and Delaware charters may permit the ratification of security issues by a majority assent of stockholders "present and voting," instead of by a majority of the whole body of owners; or else through validation by $5 \mathrm{I}$ per cent or more of the "aggregate vote." This savors of disfranchisement, certainly for the small shareholders. Acts might well be legalized through assent of a small fraction of the electorate, since the management might be counted upon to see to it that a necessary margin to meet the situation would be "present and voting." Celerity and efficiency would result at the expense sometimes of the shareholders' true interest, particularly where bonds or new classes of preferred shares were put ahead of the existing securities or by other similar manipulation of the financial set-up. 
There is a nice technique about these matters. As the head of an important central station dealing with a large body of shareholders put it, "If we really want the proposition turned down, we draw the proxy so as to require insertion of the number of shares and other details together with witness by a notary. The number of proxies returned is certain thus to be cut in halves, because of the bother. If we really want affirmative action, we get it by making the proxy as simple as possible, merely requesting that the signature be affixed." Is it not possible that this proxy situation might be substantially improved were the instrument so drawn as to permit the electorate to vote yes or no definitively, with an equal expenditure of energy either way, according as it felt disposed; instead of voting yes, let us say, under penalty otherwise of incurring disfranchisement entirely? The prime difficulty at present, in any event, is that the shareholder may not vote yes or no on any proposition. Choice lies between compliance with the proffer of the management or abstention in toto. But such abstention may not block the official plan, providing the management has taken care to secure a necessary majority of the required quorum. Only in case of a real fracas among important groups of shareholders, whereby solicitation for and against a given proposition ensues, is the shareholder afforded an opportunity for any expression of opinion except an affirmative one.

What an advantage it would be to the perplexed and isolated little shareholder under such circumstances, to have a dependable source of advice, constitutionally set up, to serve as a channel of communication between the management and the owners! And to the management, the benefit might be equally important. Through such 
an avenue a demand for further information might find satisfaction, as a precedent to approval or to denial of any action proposed; or, contrariwise, the full warrant for continuation of the existing status might be made plain to the great body of those who have the right to know.

Or, consider again how helpful a representative committee would be to management and owners alike supposing everything to be open and aboveboard - in case of a proposed sale of assets. The lay shareholder, male or female, unexpectedly confronted in the mail, or through published offers broadcast in the newspapers, with the chance to accept an offer of a certain price for stock holdings, is ordinarily perplexed. To be specific, New England newspapers are publishing at this writing halfpage offers of a price very much above current quotations for stock in the Narragansett Electric Light Company, serving the territory about Providence. This instance differs from the majority of such transactions now going on all about us in the boiling and seething consolidation of public utilities, in that in this case the price, while seemingly high, is really less than the shares are worth; whereas, the usual technique during this postwar period has been for speculative promoters to pounce upon local companies which, under somewhat sleepy managements, it may be, have not exacted the last pound of flesh from their constituencies, but which, if recapitalized sufficiently, may afford a basis for a long period ahead for full maintenance of the established scale of rates. In this Narragansett situation, however, the shareholders are sorely tempted to let go, despite a convincing demonstration by a temporary stockholders' advisory committee that they would far better leave 
things as they are. Our proposal would substitute for this temporary committee, hastily created to cope with an emergency, a regularly constituted body which under such circumstances, through employment of technical advisors, might safely be trusted to give prudent advice.

There is yet another essential point of contact between management and the shareholder body. Three property rights commonly distinguished are those to use and control; to enjoyment of the fruits of use; and to alienate and to dispose. The second of these, the right of property to an enjoyment of income from its use, raises a question quite prominent in financial circles at the present time. It opens a domain, furthermore, in which the serviceableness of a shareholder's check-up representation is obvious. Corporate policy in the accumulation of surplus is hardly second in importance to that respecting depreciation. Whether the corporation fundamentally needs to be fed up, or whether it could with benefit stand a little bloodletting through larger dividends are each matters for which the elected management must assume full responsibility; but it might well profit, and the shareholders certainly would do so, from an interchange of views upon the point. A large amount of current discontent among stockholders, particularly as respects undue accumulation of surplus, has been uncovered in connection with this particular investigation. The existent protracted period of prosperity has greatly enriched a large number of corporations, both railroad and industrial. Among the outstanding examples there are Atchison, the Atlantic Coast Line, and perhaps the New York Central Railroad, the Western Union Telegraph Company, United States Steel, Allied Chemical and Dye, and a goodly number of others. Some of these, General Motors for example, have 
apparently adopted a policy of liberal distribution of current profits, so far as is consistent with full maintenance and depreciation charges. But for many of the others the rebuilding of the plant from earnings, undertaking very expensive extensions through charges to operation, the accumulation of all sorts of reserves, has gone on seemingly without regard to the right of the present generation of shareholders to the immediate enjoyment of the income of the business. Each case must of course be a law unto itself. Circumstances surrounding railroads are unique and have no applicability to manufacturing concerns. But there is unquestionably a point beyond which conservatism in the distribution of profits becomes a vice instead of a virtue - particularly when full disclosure of the undistributed profits is denied. But even for those instances in which an opportunity for full reflection of enhanced value in the current quotations is possible, so that the shareholder who desires to withdraw his investment may do so without loss, hardship still arises under an undue postponement of reward. Even sentiment has its place for consideration. The advantage of loyalty on the part of shareholders is frequently emphasized. Disappointment under too conservative a dividend policy may easily undermine such allegiance. One would like, perhaps, to perpetuate an investment which has come down through years in the family. One would sacrifice something in case of need in support of this investment. But such confidence can thrive only in an atmosphere of full recognition of the right to current enjoyment of all profits which may safely be distributed. And in any case such withholding can be justified only when it is accompanied by complete frankness as to the reason for the adoption of such a policy. The existence 
of a regularly constituted medium of communication might react helpfully in either direction, to educate each participant group in point of view of the other.

Is there not conceivably a function here which might be performed by a shareholders' representation or check-up plan? Under the British Companies Act the payment of all dividends is a matter requiring endorsement by the general shareholder body. A general comment might be prepared upon the course of the year's business, so drawn as either to tranquillize the general mind of the shareholder body or to render it alert or even suspicious. Access to all accounts and papers by and with the aid of accountants independently employed - essential parts of such a plan - would necessarily precede the solicitation of proxies. On this common ground there might be evolved a simply worded, intelligible statement of the precise issues involved, so that with this endorsement the ordinary shareholder would far more willingly attach his signature to a paper which under present circumstances more resembles the signing of a blank check than anything else. And it would be particularly helpful in respect to that rather absurd proceeding at the present time whereby shareholders are asked to sign a blank check validating all acts of the directorate throughout the preceding year, regardless of the fact that they have no knowledge whatsoever, except what the management chooses to release for publication, of the things to which they are granting legal affirmation. Impracticable it would be, of course, to submit to such an electorate even if they would take the trouble to try to understand it - the minutes of the board of directors. But such a record ought to be looked over and checked up by somebody independent of the management before such 
unqualified assent is given. A shareholders' representation committee with expert paid assistants might well perform a useful function, terminating what is really, when you face it squarely, a perfectly ridiculous proceeding as at present carried out.

But positively the largest single grain of comfort which directors of our great corporations might discover in this proposed participation of shareholders has to do with possible amelioration of their legal liability in dollars and cents. When William Rockefeller and his fellow directors of the New Haven Railroad in I920 settled a suit for such liability by the payment of $\$ 2,500,000$, a striking demonstration was afforded of the possible risk to management in the absence of a check-up committee. And this, be it noted, was a suit prosecuted for mismanagement and waste of the funds of the railroad, but without charge of personal profit to the defendants. Such cases as these are sharply differentiated from those like the American Malting Company, where recovery was gained for positive action - the unwarranted declaration of dividends to the personal advantage of members of the board. A more recent decision in Massachusetts is that in the case of the New England Oil Corporation providing for the recovery of $\$ 3,327,000$. This opinion, if upheld upon appeal, is directly in point. "A striking illustration of the abuses incidental to interlocking directorates ... the fundamental question . . . is whether this Committee . . . did act as the qualified and faithful trustees of the creditors of this estate." And then again there is the WillettSears case, just now before the Massachusetts Supreme Court on appeal. In the lower court the bankers and management - "insiders" - have been held liable in the tidy sum of $\$ 10,534,000$. The natural tendency in favor 
of recognition of a status of trusteeship for directors of corporations toward the main body of shareholders is bound to be accentuated by the post-war development of the device of nonvoting classes of shares. Not only in cases of actual personal profit at the expense of the beneficiary, but also in cases of negligence or of the existence of an adverse interest may this imposition of a fiduciary relationship be recognized. Such recognition, in fact, is the only wholesome check, in absence of legislative prohibition, upon evil results from the nonvoting shares created before the bars were put up by an aroused public opinion.

Under these circumstances might not the expedient of a representation or check-up committee of shareholders afford a welcome relief to managements when faced with this new legal obligation? It may undoubtedly become in time a serious responsibility to accept a directorship of a large corporation. It is not that such participation by the shareholders should hamper or really divide responsibility - that would be a blunder; but rather that the fact that the board had taken counsel with such a continuing body, representative of shareholder opinion and interest, should serve as proof of good faith in case doubt should be raised or litigation pressed. Nor even, under delicate circumstances, need disclosure necessarily be made of all the facts to all the shareholders at the time. Not infrequently it might be impolitic in midstream of negotiation to indulge in such revelation. But if the case were squarely laid before this representative body, thereby affording an opportunity for a free interchange of opinion in advance of action, it might be an ever-present help to the directorate in time of trouble, especially as against the allegation of private or personal advantage as a leading motive. 
And, in conclusion, would not the direct result of this current advisory participation by owners certainly serve the purposes of a business education? A prime objection to disfranchisement, to my thinking, is that, in constituting the shareholders a mere aggregation of economic wards held in the hollow of the banker hand - benevolently, let us say - the best possible gage was given for a progressive subordination of the many to the few. The ultimate goal, unthinkable in a democracy, would be the concentration of all property power in the hands of a small company of interested all-powerful experts. The city of New York already contains a sufficient sample of such possibilities to satisfy the average citizen. Political democracy would surely succumb to the strain of such a condition. The only safe recourse is to cultivate ability by affording an opportunity for its exercise. Only by jumping into the water do people learn how to swim. Only by having some voice in the handling of their material possessions will it be possible for people to perpetuate a civilization founded as on a bed rock, upon the institution of private property.

An important objection must, of course, be met head-on: that the creation of a representative agency would tend to accentuate rather than to destroy the already disquieting inertia of shareholders; in other words, that they would wash their hands entirely of surveillance, having turned this task over to their elected representatives; and that such a body would soon go the way of all such flesh - be captured by the management and used to serve its own ends. The answer is that the shareholder could in no event be deader to the management world than he is now. And much of this inertia is the fault of managements themselves. Many of them have deliberately 
raised barriers of all sorts against interest or participation by the stock-owning public. The annual meetings are held in the most inaccessible places, in far-off chartermongering states, Delaware, South Dakota, or West Virginia - even New Jersey is in some respects a long way from New York. Financial statements have more or less conformed to the instructions which it is reported were sent out by a bureau chief to his subordinates once upon a time in the United States Department of Agriculture, directing them in drafting replies to letters of public inquiry "to be clear and cryptic." And in general the oldfashioned type of corporate management was prone to assume what in college parlance is known as a "high hat" attitude toward the inquiring shareholder. On the positive side, is there not hope that a direct stimulus to cooperation and understanding on the part of at least an intelligent minority of the shareholder electorate might be afforded by the setting-off of a stockholders' representative body having certain definite functions? Thus it is with human beings, all eager to find a place in the sun. The accordance of an assured status, the assistance of a technical expert, reasonable resort to corporate funds, together with the right of access to accounts and records would certainly confer a prestige upon such a body which would make membership in it attractive to able men. Add to this the positive encouragement from the management side, arising from the definite contribution to its own well-being; all this makes it appear that the experiment is worth trying. And at most, or rather at least, conditions could not be more unsatisfactory than in too many instances they are now. 


\section{VI \\ LIGHT AT THE CROSSWAYS \\ STOP, LOOK, LISTEN!}

When two highways intersect in the country with but an occasional passage of slow-moving vehicles and with a clear view all about, the public safety cares for itself naturally. But when the volume of traffic increases; when high-powered cars and heavy trucks are propelled at speed by careless or drunken drivers; when a fleet of little irresponsible and often overcrowded craft out for a holiday dots the stream; when great structures, pushed forward to the utmost building line, obscure the vision then, as the appalling record of death and casualties betokens, the time has come for public supervision at the crossways. Necessity may arise for the posting of officers or of automatic signal towers at junction points. Even before resorting to these extreme measures, however, the simple remedy of visibility suggests itself. Electric flood lights by night and the removal of all obstructions that hamper outlook are immediately. in order.

This homely figure is applicable to the present condition of our corporate affairs in the United States. The sudden advent of widespread popular ownership of corporations since the World War has created entirely new circumstances and conditions in the business world. Main Street and Wall Street have come to cross one another at right angles - Main Street, our synonym for 
this phenomenon of widespread ownership, and Wall Street, as applied to the well-known aggregation of financial and of directorial power in our great capital centres. This intersection of interest, so often at cross purposes, is marked by an imminent danger of collision at the junction point of ownership and management. The volume of business, the high speed of propulsion, the growing obstructions which stand in the way of visibility, suggest that in this domain also a prime necessity is the letting in of light to the fullest degree. Our American business affairs, in so far as they have assumed the corporate form through this recent growth in public ownership, are still too largely carried on in twilight. Great progress has already been made; but it is high time that the imperative need of putting things upon a universally sounder footing be generally understood.

Historically, an extraordinary improvement has taken place as respects corporate publicity within the last generation. Accustomed as we are to complete current statements from railroads, we forget that the New York Central half a century ago rendered no annual report of any kind to its shareholders for years on end. A picayune balance sheet was submitted to the State Engineer occasionally. Some carriers were more considerate. Early reports of the Chicago and Northwestern contained the names of shareholders with their addresses. It would require nowadays a tome as heavy as a city directory were the "American Tel. \& Tel." to list its 360,000 owners. The American Sugar Refining Company, about 1900, had over 10,000 shareholders, thus standing in the forefront of private manufacturing corporations publicly owned. The utmost information that was extorted, year after year, was a balance sheet like this one of I90I, 
filed under compulsion, as a license to do business, with the Secretary of State of Massachusetts.

\begin{abstract}
Assets
Real estate and machinery

Cash and debts receivable

Sugar, raw, refined, etc.
\end{abstract}

Investments in other companies

$$
\begin{array}{rlr} 
& \text { Liabilities } & \\
\$ 34,328,664 & \text { Capital } & \$ 88,280,370 \\
36,862,702 & \text { Debts } & 24,364,027 \\
12,248,640 & \text { Reserves, } & \\
\text { balance } & 9,907,491 \\
39,111,883 & & \\
\$ 122,551,888 & & \$ 122,551,888
\end{array}
$$

One might forgive this solicitous Commonwealth far in advance of its sister states in demanding even this dole - for the omission of the requirement of all semblance of an income account; but it passes understanding why nobody took umbrage that the items stopped at round dollars, instead of being posted to the last cent. Perhaps it was because of the extenuating fact that, despite the magnitude of the totals, the assets so exactly equalled the liabilities! Possibly, indeed, because of apprehension lest, if pushed to the penny, this perfect equilibrium might be overset or some irregularity divulged! The incident recalls the good old soul at an experience meeting, moved to rise in her place and say that although her dear ones had passed away, although she was poor and in ill health, somewhat deaf and growing blind, with only two teeth left in her head, "Thanks be to God, they hit." The books balanced. What more might one expect in those far-off days?

Once upon a time, too, in 1887 , a committee of the House of Representatives sitting on this same sugar trust had somewhat better luck, illustrated by the following succinct colloquy with $\mathrm{H}$. O. Havemeyer, economic dictator of the concern.

Q. As a member of that board, what else have you done? A. Oh, I have convened and talked. 
Q. You have convened and talked? - A. And adjourned.

Q. Well, you have convened and talked? - A. And adjourned.

Q. Well, what have you talked about? - A. Statistics.

Fortunate, indeed, that they talked about statistics, because, while turning out each year millions of pounds of saccharine matter, anything so nourishing as statistics, for public consumption, was the last thing in the world which this "octopus" produced. It was not even willing to furnish any to the Federal Census authorities in I 890 . And because of this refusal the attentive student of manufactures, consulting ponderous tomes, discovers an apparent drop in sugar production in New York State within the decade, from $\$ 71,000,000$ to $\$ 17,000,000$. Looks like an error of the typesetter, the digits transposed. But really, you know, it was the play of Hamlet with Hamlet left out. And the statisticians let it go at that - as they did in Russia under the Czar, when they used to put forth those imposing volumes of statistics of agriculture. Some enumerators counted hives. Some turned in data as to bees. Too late to quibble about details! So they just merged them all in one grand total indicative of the progress of apiculture.

Other striking examples of sealed situations of this period are the Westinghouse Company, which seems to have held no annual meeting for almost a decade prior to I906 (I897-1905), and the United States Express Company, which, under the benignant domination of Senator ("Boss") Platt, held no meeting within the memory of man, neither vouchsafed any statement whatsoever of financial condition to the owners of the property. Small wonder, then, that an early government report on the subject in 1900 states that "one of the 
chief evils of large corporations is the lack of responsibility of the directors to the stockholders. In many cases the directors hold their positions for a series of years, and practically never make reports that are calculated to give to the individual stockholders much light on the actual methods of management."

How many plain, ordinary American citizens have suffered something like the following experience, paraphrased in this instance from a forceful description by a denizen of Wall Street himself? A stockholder in the X. Y. Z. Corporation receives a blanket proxy for the next annual meeting of the concern for the purpose of transacting such business as may lawfully come up for consideration. There is a request to sign on the dotted line, giving the president of the company, by proxy, the right to vote. There is a natural desire, before granting this general license, - which includes, by the way, approval and validation of all of the acts of officers and directors for the preceding year, - to know a little more about the company's affairs. There is worriment, perhaps, about an investment made sometime previously, at $\$ 30$ per share, on the basis of newspaper reports that the company would show earnings of at least $\$ 6$ per share for the year. Consultation with a broker elicits a favorable opinion of the company and its management. With such excellent promise, - still merely surmise and rumor, - the chances of increase of income as well as of principal appear good. After a few months the official report is issued. The company has earned but $\$ 3$ a share, instead of $\$ 6$. The quotation drops to $\$ 24$. Yet the president, in his published statement to stockholders, refers to the company's progress, praises the loyalty of 
the employees, and holds out high hopes for continued prosperity. The quotation advances, perhaps, to $\$ 33$ a share, a little above the purchase price. There is a rumor in the press that dividends are to be increased. The president promptly denies this report. Thereupon the stock drops, hangs dormant for months, and betrays a strong disposition to sag still further. Along comes a reduction of the dividend because of the unpromising business outlook; and still no authoritative statement of earnings. It is all very disheartening - the uncertainty perhaps worse than the truth.

Dismayed at this reduction of income, the stockholder writes a letter of inquiry to the company, prompted by the loss of one third in both principal and income. The letter elicits this reply:-

The financial statement will not be ready before the annual meeting of the stockholders in March, at which time all stockholders will receive a copy. In justice to the other stockholders I cannot give you any advance information about the operations or financial condition of this company. Nor can I advise you on what policy to pursue for your investment. It is unfortunate that you have suffered a loss. I have always looked with disfavor upon having the stock of this company become a vehicle for speculation in the market. I can assure you that the company is in a good financial position. I trust that you will sign and mail your proxy at an early date.

Very truly yours,

President

This is an actual document which emanated from a company in existence for many years and with an international reputation. It was not a fly-by-night concern. As my correspondent writes, "No white-collar bandit had sold the stock." Here was a real "partner" in the 
concern, seeking in vain, either from reputable bankers or from the corporation itself, for information. Something is evidently wrong about the whole business. What usually happens, of course, is that the investor sells out, takes his loss, and strives to forget about it, investing the proceeds in another. enterprise. Will he fare better therein? And what about the second stockholder who relieved him of his former holdings? And what about the general reaction upon the little stockholder's mind? As one of them put it, "I have not been a believer in antitrust legislation, but I am changing my mind."

Confronted with a great pile of recent corporate pamphlets on my table, the first impression is of their extraordinary diversity, in appearance, size, content, and intent. One premier concern, the Royal Baking Powder Company, fails to register any fiscal information at all, in as much as it has never issued a balance sheet or financial statement of any kind whatsoever for more than a quarter of a century. Publicity it has surely courted - as witness the printed record of the old United States Industrial Commission of 1900 . But this particular kind of publicity, despite a considerable distribution of the stock, which is fairly active both in the unlisted market and on the New York Curb, seems to have been overlooked. Akin to it is the Singer Manufacturing Company, which handles 80 per cent of the world's output of sewing machines. Neither hide nor hair of financial data for this firm is discoverable in the usual sources of information. The dance-card, bald balance-sheet, or picture-book variety of corporation report follows hard upon these examples of complete reticence. For concerns like the National Biscuit Company such newfangled gewgaws as income accounts or depreciation simply do not exist. 
American Can gives you depreciation for 1925, but never a whiff concerning its accrual through past years. Diminutive, dainty, tied up with fancy string, perhaps, these reports are tenderly reminiscent of the parties of our youth. Some may have elaborately decorated covers, like paper on the wall-particularly among public utilities with extensive customer ownership. Some, like the Gillette Safety Razor Company (counting almost 7000 shareholders in 1925), are inviting pictorially, however uninformative they may be. Emblazoned with gilt or colored reproductions of one thing or another, on large sheets of heavy glossed paper, they are pleasing to the eye. Yet colored pictures of factories, brightly lighted at night, - as some of these must well have been in view of their extraordinary success, - tell no tales. What an extravagance of good paper and ink, about as nutritious as some of the advertising displays of ham and eggs or other standard articles of daily consumption in the popular magazines!

Then there is the leaflet type, done on a single folded sheet of paper. This "tuppence ha'penny" variety, once common, is happily by way of passing out. Cotton mills are still in this stage, again with nothing but a balance sheet, and no income statement at all. Some of the new investment trusts, which ought particularly to disclose full information about their holdings, have got no farther. The great American Tobacco Company has not yet progressed beyond the embryonic state. Or there is the pompous but empty type, suggestive of President Wilson's pithy distinction between men who grow and those who merely swell with the advance of years. Such reports remind one of those little men who not infrequently puff themselves up in manner to make up for their 
abbreviated build. Other reports may well be designated the "business condition" type, devoting much attention to things in general and but little to their own affairs in particular. The Standard Oil companies are doing better of late, to be sure, in recognition of their quasi-public status (the New Jersey company alone in 1923 had $8 \mathrm{I}, 000$ shareholders); but the balance sheet and the income account are still quite in accord with the prevailing style in women's dress. And then there are the reports, like Tristram Shandy, "all obfuscated and darkened over with fuliginous matter." To the uninitiated, as we shall soon see in detail, they may tell too much that is not so, or too little of what they ought to tell. Of them the Wall Street Fournal has this to say:-

Many do more to deaden than to arouse the stockholders' interest. Whether by accident or design, such reports are drawn so as to withhold from the stockholder what he most desires to know. When he is told that "the increase in mortgages and ground rents payable represents a mortgage given in connection with purchase of additional property," he says to himself that an intelligent bootblack could have guessed as much. When he reads that "the decrease in miscellaneous accounts payable is due to withdrawals by affiliated companies to reduce their indebtedness for construction and other purposes," he refrains from calling the report a mess of tripe only for fear of insulting an industrious and self-respecting farmyard animal.

This brings one to the truly informative type of official report, which fortunately is coming more and more to be recognized as not only good form, but the best of business as well. The United States Steel Corporation, now owned by I79,000 people, has from the outset followed the precept, well stated recently by Judge Gary, its president, "Corporations cannot work on a principle of locked doors and shut lips." From the first annual 
statement, outspread over entire newspaper pages in 1903, down to the present time, its record has been consistently admirable. The General Motors Company, first in its industrial class the world over, is a worthy second. It has 56,000 shareholders. And in the field of public utilities the Philadelphia Company and the Consolidated Gas, Electric Light and Power Company of Baltimore offer prominent examples of reports as simple and understandable as their complicated structure permits. Another model statement, suitable for smaller concerns, combining full publicity, made as intelligible as possible, with pictorial evidence of the development of the business, is that of the Dennison Manufacturing Company, with its 800-odd shareholders. These and other entirely adequate statements, full-figured, compact, and businesslike, used to be the exception, but it is greatly to be hoped that in the early future they may become the rule. How to bring this to pass is a matter of the utmost importance.

Stockholders are entitled to adequate information, and the state and the general public have a right to the same privilege. First of all, we must remember that incorporation is a privilege. The people grant to a private body the ineffable enjoyment of immortality, of succession, of impersonality, and, greatest boon of all, of limited liability. Under partnerships or other purely private forms of organization, where trading is carried on without limitation upon the personal liability of those who engage therein, certain obvious safeguards for creditors and the public arise from the purely personal attributes of the concern. The grant of limitation upon this personal liability for debts or other obligations by public act 
abrogates many of these formerly existent safeguards, which must of course be offset by new provisions at law. But in any event the release from these personal obligations affords so great an advantage, and is accompanied by such novel risks, as to make it clear that it is indeed a privilege, conferred out of hand by gift of the people. In other countries where these valuable grants proceed from a single source, and that, too, a supreme one - to wit, the central government - this privilege is more likely to be taken at its face value. But in the United States such public gifts are scattered with a lavish hand by forty-eight different little sovereignties, more or less jealous of one another, both financially and prestigiously. Whence it comes about that the selection for purposes of incorporation of one or another from among this ardent band of states has become a matter of corporate largess, when it should rather be one of respectful petition. In other words, the normal relation of suitor and besought has become reversed. Confusion both of ideas and of policy on this point has mulfuthered the whole business of incorporation in the United States.

The contention for corporate publicity has derived expert support recently as an adjunct to industrial efficiency. Scientific comparison of costs of production, sales, or what not, has become almost a slogan in American business. The right of trade associations to pursue such statistical policies has been twice reviewed by the Supreme Court of the United States of late; and this august tribunal within the year has set the seal of approval upon such practices, acceding to the argument that comparison of past performances is bound to contribute to the general stabilization of market conditions. The recent report of the National Industrial Conference 
Board upon trade associations is a concrete manifestation of the aroused interest in this matter. One hears less frequently of the slurs which used to be cast, from within, upon movements of this sort: "prying or prurient curiosity, not to be gratified - and which," to quote a prominent attorney, "ought not to be gratified."

Not so technical, but of wider scope, is the bearing of complete corporate disclosure upon the so-called trust question. It is now a quarter century since the United States Industrial Commission put forward this remedy, first among a number of proposals for dealing with industrial combinations. Little attention was paid at the time to the argument that such revelation of profits by concerns which threaten to oppress the public would operate almost automatically, like a lowering of tariff barriers, to invite corrective competition. The secretive tactics of the National Biscuit Company, later to be commented upon, are quite commonly ascribed to a desire to entrench itself beyond all possible competition as a low-cost producer before divulging the profitableness of its business to possible rivals. Decision as to the right of public authority to information about profits, as we shall soon see, is expected shortly from the Supreme Court of the United States in respect to both steel and coal-mining enterprises. President Coolidge's remedy of a fact-finding federal agency for anthracite coal mining finds its main warrant as a safeguard against extortionate price practices. I hold it to be self-evident that such publicity would render unnecessary much of the further-reaching antitrust legislation which at one time or another it has been proposed to put upon the statute books.

Such publicity, furthermore, over and above the 
immediate right of the actual owners to an account of stewardship from their managing agents, has a bearing on taxes. For the moment the reaction against publicity of income tax returns for persons has been used to further a similar recession of such disclosure for corporations. But the tide will certainly flood again for such impersonal concerns. Taxation is as unthinkable without illumination as it is without representation. Publicity also is significant in connection with the legitimate activities and aspirations of those who work with their hands. Wage earners, whether interested as incipient capitalists or not, certainly feel as they become class-conscious that they have a right to know what is the relation of the return for the work of their hands to the rewards which accrue to the employer for employment of his brains. Many a case of labor unrest, notably the pathetic, persistent, and apparently praiseworthy strike of the silk workers recently at Passaic, would settle itself almost automatically, one way or another, by the very force of public opinion, were all of the facts to be made generally known. Such is the keynote of the Canadian Compulsory Investigation Act, as of other legislation of the same sort elsewhere. It is indeed true that corporate publicity is, so to speak, on the air, broadcast from all sorts of stations. And the distinctive phenomenon of the postwar period, the transformation of small family concerns into corporations owned by the general public, - the evil generally being in inverse ratio to size, - emphasizes the point that corporate obscuration has long outlived its day.

The advocacy of really informative publicity as a corrective for certain of our present corporate ills must be placed in its proper relation to the whole matter of 
democratization of control. A prime argument which raises its head at the outset of all discussion of shareholders' participation in direction is that the shareholder - the owner, in other words - is hopelessly indifferent to the whole business. His inertia as respects the exercise of voting power, and almost everything else, is an acknowledged fact. But no one expects it to be otherwise. No one believes that a great enterprise can be operated by town meeting. It never has been done successfully; nor will it ever be. The ordinary run of folks are too busy, even were they competent enough. Nor is it true that the primary purpose of publicity, the sharing of full information with owners, is to enable these shareholders to obtrude themselves obsequiously upon their own managements. But such information, if rendered, will at all events serve as fair warning in case of impending danger. And this danger will be revealed, not because each shareholder, male or female, old or young, will bother to remove the wrapping from the annual report in the post, but because specialists, analysts, bankers, and others will promptly disseminate the information, translating it into terms intelligible to all.

This, of course, will take time. The annual meeting will long have been passed; but - and this is the nub of the whole business - an opportunity for a reflection of this revealed condition will have been afforded in the meantime, leading inevitably to the quotation of a just and true price based upon such conditions. Our great exchanges - and no little investor should ever own securities for which there is not a great open public market at all times - can perform their proper function of making true prices, consonant with valuation, only when there is such disclosure. This, then, is the ultimate 
defense of publicity. It is not as an adjunct to democratization through exercise of voting power, but as a contribution to the making of a true market price. This is a point but half appreciated at its real worth.

The Lehigh and Wilkes-Barre Coal Company affords an extreme instance of the deprivation of minority holders of the right to information - an instance, by the way, of the policy of secrecy characteristic of anthracite coal mining in general. No other basic industry in the United States is so nearly a sealed book to shareholders and the public. For years no dividends were paid by this company; nor were any reports issued. Yet apparently a surplus was built up which subsequently was distributed in two special cash dividends of I 50 per cent and of 70 per cent in 1921 , in connection with the dissolution decree of the Federal Supreme Court. It appears that a part at least of these liquid assets was accumulated during the early nondividend years. After I92I dividends were paid for a couple of years, but still no annual report for twenty-four months. Since 1925, dividends again have ceased on the common stock. Such arbitrary treatment of stockholders having a substantial investment in the business is difficult to justify. Think what injustice in case they wish to dispose of their investments during this time. How could anything like a true price be made under such circumstances? Is this not, then, the ultimate basis of the right of every partner in an enterprise to such disclosure as shall assure him against an artificial or even a rigged price? Abnormal market prices, based upon inside information, are perhaps one of the most vicious features of the present situation. Relief from this menace may be had only through insistence upon complete revelation, as opposed to what 
has been so aptly described by Hastings Lyon, referring to certain too prevalent practices among public utilities, as "limitless obfuscation."

The two essentials of an adequate statement are the balance sheet and the income account. The former discloses the condition of the company statically - as at a given moment. It is an instantaneous photograph, giving a cross section, so to speak. The income account, per contra, reveals, dynamically, the course of affairs in perspective - viewed lengthwise throughout a period of time. Each is essential to a complete understanding. As well, otherwise, attempt to figure the area of a floor with one dimension lacking; or to write a person's life from a packet of daguerreotypes. Everything becomes guesswork unless both are given. "Handsome is that handsome does" is a familiar proverb, expressive of popular wisdom. It is as applicable to corporations as to people. The balance sheet reveals what the corporation is; it gives but an inkling of what the corporation has been doing. There is just the difference involved between being strong and "going strong."

Of the two, the income account is perhaps more significant, both immediately and prophetically. Yet of the two it is the income statement, as perhaps too informative, that is the more apt to be suppressed. In England, despite the strictness of the Companies Acts, and still even in the staid Commonwealth of Massachusetts, all that is required by law is the filing of an annual balance sheet - lest possibly the income account might give aid and comfort, or the reverse, to competitors. But in general the world has long since passed the time when corporations may refuse to their shareholders an income account 
in addition to the balance sheet. It is certainly out of line with the best business practice that the Amoskeag Manufacturing Company, the greatest cotton mill in the world, should render an income account primarily in yards rather than in dollars, along with a petty trial balance; or that the Waltham Watch Company, owned by more than 3000 people, two years after reorganization, after having appealed to the public for subscription to its securities, should still vouchsafe nothing but a skeleton balance sheet. Such meagre reports are incompatible with the best modern standards of business practice.

At the threshold of intelligent corporate publicity stands a clear distinction between capital and incomethe assurance that the property in being used is not being used up. For, unless it be certain that the investment has been at all costs kept whole, there can be no security that it is not being in part redistributed under the guise of profits. It is fundamental, in other words, that socalled profits should all of them have been really earned, instead of having been partially abstracted from the capital fund. The necessity at law for observation of this principle has never been more forcibly stated than in the heinous case of the American Malting Company, in 1904. The court required that the directors return to the corporate treasury, for the benefit of stockholders, $\$ 500,000$ in cash and $\$ 1,000,000$ in common stock, equal to dividends which had been declared although actually unearned. This was the reason: "The ordinary purchaser of corporate stock holds it as an investment. He rightly considers and treats the dividends paid upon it as income. In many instances the income is required to meet the expenses of living, and is entirely expended for 
that purpose. To say that a person who has been unwittingly induced to exhaust his principal by the mistaken or fraudulent representation of those to whom he has entrusted it, that what has been paid to him is income, suffers no injury is absurd. To refuse him redress, except upon condition that he return the moneys which he has expended, in the belief that his capital was intact, notwithstanding that by such expenditure he is rendered penniless, - is to put a premium upon fraud in corporate management." This dictum at law utters a sound and necessary practical truth concerning property management. The first point in analysis to be sure about, then, is that the stated earnings are truly earnings and nothing else.

The finer distinctions as respects keeping the investment intact are well put in the admirable report of the Philadelphia Company for 1925, each item being discriminatingly treated therein. "Maintenance represents the cost of keeping the property in an efficient operating condition." "Depreciation is the provision made for retiring, renewing, or replacing property through deterioration, obsolescence, and depletion." The relative importance of each of these will vary with the business. With a heavy plant investment, maintenance will be relatively high; depletion is a first consideration in oil or mining ventures; obsolescence may loom large in a rapidly developing pioneer industry, as in the public utility field to-day. ${ }^{1}$ But, taken collectively, they must all be treated, not, as too commonly occurs, as condiments, but as true vitamins. They all, in the field of accounting, conform to the little girl's definition of salt -

1 On German law and practice, unsound distinctions between depreciation on fixed and circulating capital, and so forth, consult Ripley, Trusts, Pools, and Corporations, pp. 783 et seq. 
"something which spoils everything that you don't put it on." As well figure your personal expenses without keeping the teeth and health in sound condition. Statements devoid of adequate charge-offs for these purposes, according to the varying local conditions, are utterly meaningless. Sound business practice should even make allowance for them before deduction of interest charges, as a disclosure of the true picture. Even the bondholder, viewing his claim to interest as a primary deduction from earnings, will be deceived if he fails to realize that the full long-time security for his lien rests rather upon the preservation intact of the corporate estate than upon the immediate likelihood of having current interest charges met. For, unless he first charges off, mentally, from earnings an amount equal to this depreciation, he will underestimate the possibility of a failure of his income in the years to come, as well as the disappearance of his principal at maturity. Such being the case for the creditor, how much more important is it for the shareholder, the real owner, to be advised at the very outset as to the preservation of his capital fund intact.

Relatively few, even among men of affairs, appreciate the importance of caring for these matters well in advance, and liberally, too. The Federal Trade Commission in 191 5-I6 discovered that, out of sixty thousand successful corporations doing a business in excess of $\$ 100,000$ a year, fully one half of them reckoned with depreciation not at all. It is often, in fact, confused with maintenance. Take the common plight of the little householder, for example, straining every nerve to purchase a home. He proceeds gayly for a year or two, care-free even of maintenance. Then it appears that paint is becoming dingy, small leaks occur, furnishings wear out, 
petty repairs are needed. These, let us say, receive prompt attention; but finally in due course the spectre of major replacements arises - new roof, new heating plant, new plumbing. Without foresight - knowledge that the plant, however well repaired, must yet be replaced at the expiration of its due term - there is nothing for it but a mortgage to cover this contingency certain. With motor transport, the point is not less inevitable, but a little less obscure; thousands of truck owners calculate their charges for a while on the basis merely of maintenance - that is to say, current repairs, regardless of the charge-off to meet that day of reckoning when it almost costs more to keep than even to give away the old thing. But in these instances negligence or ignorance entails a corrective penalty upon the one directly at fault. In the corporation, the great business unit, to just the degree that ownership truly registers responsibility in policy is the incentive strong to keep the facts as to retirement in the very forefront of affairs. But when ownership and direction have drifted asunder the temptation is to forget retirement altogether; to blink it; to postpone the evil day of settlement; to hope that somehow things will work out; or to get out before the facts are discovered. This temptation is so deep-rooted in human nature as to load the scales in favor of secrecy at just the time, perhaps, when, in the long-run interest of the real owners, disclosure is the imperative need.

The present-day custom of buying on installment affords a powerful incentive toward Micawberism. How possibly can the radio set, the piano, or the automobile be wearing out? Why, it is n't even paid for yet! The day of reckoning when replacement becomes imperative, when scarcely the last installment on purchase has been 


\section{I76 MAIN STREET AND WALL STREET}

paid, suggests the unlucky wight who threw up his job because he got so tired, as he was on the way home, of the sight of himself just going out to work. When one faces such a situation in individual experience the principle involved is self-evident. It is less apparent - often completely obscured - with great businesses if they are run on "pleasant-day" policies, or with an eye to the stock market rather than to permanent upbuilding.

Obsolescence, due to the fact that the world moves, is the most subtle and, possibly, the most undermining factor of all. When the New England Cotton Yarn Company started out in 1902 with a great investment in machinery operated by skilled English mule spinners, its proponents little dreamed that the great influx of foreignborn unskilled operatives would create the necessity of substituting ring-frame spinning machines throughout their mills. Bankruptcy ensued, partly through the failure to foresee this contingency. But more sudden or incalculable are the changes which come about in popular habits and customs. The American Ice Company has had to weather one such shift, in the practical supersession of its large investment in natural-ice warehouses, up the Hudson and all along the New England coast, through the development of artificial-ice plants close to the points of consumption. And now electrical refrigeration, even in the domestic ice box, promises to bring about a second complete revolution in the business. Think how bicycles have come and gone, and of what happened to the American Bicycle Company! The horsedrawn vehicle has virtually disappeared before the automobile. Even more disconcertingly, as a prominent manufacturer recently complained, describing the depression in his own line of business, "the bottom has 
dropped out of baby carriages," not only because of a declining birth rate, but because of the activities of Henry Ford. Besides the wear-out and tear-out of plant which must be cared for in every line of business, the veritable transformation of the underlying economic conditions themselves must be taken into account. To meet all such circumstances must, of course, be a matter of judgment and of degree; but to live in and for the day, rather than in the light of the long-time future, when the interest of thousands depends upon the decision, becomes almost a crime.

Enigmatic accounting, obscuring the distinction between capital and income, was never better exemplified than in the case of the American Woolen Company, now in the doldrums or worse because of the sins of its former management. This concern, with upward of $\$ 100,000,000$ of capital stock and loans, with 35,000 shareholders and an army of employees scattered all over New England, would seemingly be affected with a public interest merely by reason of its magnitude. Yet Cole, in his American Wool Manufacture, a serious and competent study, is practically unable to make out whether "the preferred dividends were not on the average earned in the whole pre-war period," covering some fifteen-odd years. He makes it appear, in fact, "that the surplus built up in I9I2 to $\$ 12,000,000$ was at least in part the result of inadequate provision for this item" [depreciation]. To such a policy of accounting and management the euphemistic title, "pleasant-day" finance, is applied. Is it any wonder that bad weather has now succeeded, as the wheel of time revolves? The flippant attitude, or worse, of men high placed in responsibility, treating this matter as if it were nobody's business 


\section{I78 MAIN STREET AND WALL STREET}

but their own, is illustrated by a bit from the crossexamination of Havemeyer, head of the old sugar refining company, in 1900 .

Q. (by Mr. North) Are you now carrying on business at a loss? - A. I have answered that before; I have no other answer to give to it.

Q. You refused to answer it before. - A. Well, I refuse to answer it now.

Q. How do you carry on business at a loss and still declare dividends? - A. You can carry on business at a loss and lose money, and you can meet and declare dividends. One is an executive act and the other is a business matter.

And here is another bit of testimony similar in hue from the treasurer of the Bay State Street Railway in Massachusetts, in 1916.

"What is the extent of impairment of capital here in this $\$ 50,000,000$ corporation?" asked Mr. Wadleigh.

"I cannot answer that offhand," said Mr. Rockwell, "and it appears to be an academic question anyway."

"Do you think it wise to have paid dividends at the expense of depreciation?"

"Yes, in order to keep the road's credit good. It's a matter of business judgment."

"Are n't all dividends extravagant, if they are not earned?" "That's an open question."

Perhaps the most extreme object lesson in this field is afforded by the downfall of the Consolidated Lake Superior Company, in 1902 - a huge mining, steel-manufacturing, and shipping affair at Sault Sainte Marie. This company, capitalized at over $\$ 100,000,000$, was largely sold in Philadelphia and Toronto on the basis of alluring generalities. Mystery was treated as an asset, on the ground that publicity would be too informing to 
competitors. Dividends were paid entirely from capital for nine months; the bubble burst; and the assets were bought in for less than one tenth of the face value of the securities sold. Differing not in kind, but only in degree, was the case of the American Grass Twine Company in 1905, where the directorate was forced to reimburse the company for $\$ 650,000$, representing unearned dividends practically declared from capital; and a still larger sum was involved in similar proceedings along about the same time in the Electric Vehicle Company. It was the decision already quoted in the American Malting Company litigation in 1904, which for a time disposed of this crucial issue. No other flagrant case occurred again until I9I3, with the depletion by $\$ 1,250,000$, largely through payment of unearned dividends, of the working capital of the United States Finishing Company.

By no means, however, are corporate reports respecting property upkeep always on the wrong side of the ledger. As commonly, perhaps, in case of prosperous companies is the true situation concealed - whether for the benefit of insiders or not - by understatement of allowances both for maintenance and for replacement. The old American Tobacco Company afforded one of the best instances of the accumulation of undisclosed resources. This concern carried so-called "tin tag" reserves. They were for the purpose of offsetting the liability of the company for redemption of outstanding tin tags, a form of advertisement employed when, where, and as tobacco chewing was a fine art. These reserves at times exceeded by several million dollars the amount actually required for the purpose. And whenever the American Tobacco Company had a bad year the income 
account could be inflated a bit by drawing off from this reservoir.

American Can and National Biscuit, whether dominated by the same group in management or not, are alike notorious for obfuscation in this regard. In the former case, American Can, after a nondescript depreciation policy in I912, suddenly, from $\$ 500,000$, increased its allowance of this sort fivefold. This held the publicly stated net earnings to an unchanging level, despite everincreasing profits. Then, by suddenly dropping depreciation charges back to $\$ 1,000,000$ in the next year, the published net earnings were of course jumped twice over. Coincidently, in I9I3, \$14,000,000 of debenture bonds were issued to pay off a 33 per cent accumulation of preferred dividends. Could anybody on the inside, with foreknowledge of the course of events, possibly have profited from a concomitant rise in the common stock quotations from \$I I per share to upward of $\$ 50$ ?

The National Biscuit Company, with I 5,657 shareholders in 1925, the largest manufacturer of its kind in the world, has likewise roughly handled its accounts, always on behalf of those "in the know." Net earnings after the war, as reported, long failed to reflect the full measure of profits, through resort to all sorts of fancy charge-offs to depreciation. History does not relate whether this concealment of profits was to discourage industrial competition for the time being, or was, as rumored, on account of the heavy war taxes on corporate income. Anyhow, all of a sudden came an abrupt abandonment of this ultraconservative depreciation policy in 1922. The number of shares was multiplied sevenfold, accompanied by an increase four times over in the amount of dividends paid. This fulguration through the long 
overdue disclosure of earnings was, of course, at once reflected in bounding quotations for the stock.

The Allied Chemical and Dye Corporation is the leading manufacturer of coal-tar derivatives and chemical products in this country, and probably in the world. This concern is equally notorious for overloading its operating expenses with such deductions. The aggregate now exceeds $\$ 100,000,000$ for depreciation, obsolescence, and contingencies, although the abbreviated income account for I 925 gives not the slightest indication of the charge-off for that period. And on top of this is a "Capital Surplus," and this in turn is capped by a "Further Surplus," the two aggregating over \$150,000,000. Are its shareholders to have the same experience as those of National Biscuit? Not even the most expert analyst can discover from its attenuated income statement what is the basis of its various revaluation, retirement, and depreciation reserves. How ridiculous that public partners in this enterprise, consulting banking experts, should have to be advised that such an official income account "does not by any means give a clear picture of the annual earning power," or that "the balance sheet by no means discloses the true value of the company's fixed assets." It approaches public scandal that corporations of such importance should thus play fast and loose, not only with the public, but with those whose capital is really invested in the business.

The practice and possibilities of an intelligent preservation of the capital fund intact vary widely from industry to industry. The greatest laxity, especially as respects depletion, obtains in the field of mining. A refreshing contrast to the prevalent policy of neglect or obscuration among corporations of this sort is the 
practice of the American Smelting and Refining Company. Not only are depletion and obsolescence separately stated on both income account and balance sheet, but even a "new reserve for mine and new business investments" of $\$ 1,000,000$ is set up in 1925. The General Electric Company, in view of its conservative policy respecting such matters, - research in particular, - might perhaps do well to imitate such particularity of statement. Among railroads the gravest abuses were characteristic of their history down to about 1900 . The present situation has become satisfactorily stabilized. There are governmental standardization and complete publicity of the accounts. Upon the basis of long experience, the rates of wear-out and tear-out are fully known; so that the charges each year upon current income can be counted upon with certainty to keep the property whole. ${ }^{1}$ And then the large investment in real estate, right of way and terminal properties especially, substantially appreciating in value with the growth of the country, may be trusted to compensate for whatever shortcomings as to depreciation policy occur. For the older public utilities, gas companies and water works, long experience has consolidated the practice. But for the electric light and power companies, which are still in the speculative and pioneer stage of development, the treatment of these matters is still uneven and in some cases most unsatisfactory. Thus far disaster has been avoided because of the essentiality of the service, combined with the appreciation in prices and in land values. But whether the financial practice of these companies in the issuance of securities, based as it is upon a reproduction theory of valuation at the very crest of a period of inflation of prices following the

1 Cf. the example on pp. 242,243 , infra. 
war, will work out satisfactorily or not still remains to be seen. It is in the remaining field of purely private industry that the danger of self-deception or of undue reticence reaches a climax. And it is because of the penetration of popular investment into this field of private endeavor that the lesson must be driven home, that manufacturing instrumentalities, however perfectly repaired, - that is to say, maintained, - have, like the one-horse shay, a definite, although often unascertainable, length of life. Neglect of this point may readily enough bring it about that an investment which has recently passed from individual ownership into the hands of thousands of small stockholders, with a possibly irresponsible banker management, which for the moment looks as firm-seated as the American Constitution, may suddenly turn out to be highly evanescent and disappointing.

That "time is money" is peculiarly true in this matter of corporate publicity. An inordinate delay too frequently attends the issuance either of current statements or of the annual reports. It may be four months along in the spring before a tardy exposition of the state of things for the preceding calendar year is available. But if the greatest and most complicated business concerns can give prompt reports, there is surely no excuse for the corporations of lesser importance. And unfortunately it is especially in these secondary corporations that delay is most unconscionable. Reservation of important information would not go unchallenged with companies of the first class, especially if listed on the great exchanges. An argument for simplification of structure arises at this point. This is peculiarly true with the overdevelopment of the holding company in the field of public utilities. 
I have one of these in mind, with eighty-two constituent corporations, for each of which statements must be made up independently before being consolidated in the top company. It is extraordinary what may be accomplished, however, in spite of the attendant difficulties, in the way of assembling and putting forth financial data. "Where there is a will there is a way" could scarcely be more aptly manifested than in this particular field.

And now for the income accounts! The niggardly National Biscuit Company, in its three-by-four-inch balance sheet, stingy even of prepositions, gives us this and nothing more: "Earnings, Year 1925." Such a policy, mysterious or macabre, invites the comment that the record is either too good or too poor to be frank about either way. Once again, maintenance and depreciation items would be elucidating. The widest range in this regard, from nondisclosure to entire candor, obtains. The General Outdoor Advertising Company follows the plan which will be criticized later on, so generally adopted for public utilities, of bulking maintenance and depreciation indistinguishably in one figure. Billboards, of course, are a peculiar type of investment; but only a tyro would assign the slightest importance to such a statement without more information concerning upkeep or development. Many companies which recognize depreciation as a distinct item in operating expenses treat it rather as an arbitrary amount which may be set aside or not, according to circumstances, after socalled net profits have been determined. Continental Gas and Electric Corporation is typical of most of the utilities which report net earnings after deducting all operating expenses "but before deduction of taxes and depreciation." Such a policy really makes use of de- 
preciation to smooth out the curve of net earnings from year to year, setting off depreciation heavily in good times and letting up on it otherwise. The real fact is that depreciation is just as much of an operating expense as the consumption of supplies. Mack Trucks is on a sound basis in not figuring net earnings until it has taken care of this item. If appliances and other machinery of production must be replaced at the end of a working life, a failure in each period of time to care for the due proportion of wastage is merely postponing trouble. Then there is a group of companies like Dodge Brothers, Incorporated, and Goodyear Tire and Rubber, both under the same banker management, for which the word "depreciation" might just as well not exist, so far as their profit and loss statements are concerned. How striking by way of contrast is the white-hot lucidity of the American Locomotive Company report for 1925, frankly wiping out all profit and transforming it into a heavy deficit in order to make full allowance for wear-out and tear-out. It is interesting, moreover, as indicating public appreciation of such frankness, that after the deduction of a similar surplus converted into a huge deficit in the report of the American Agricultural Chemical Company of June 30,1923 , there was a marked advance in the share quotations instead of what one might have expected would follow so adverse a showing. It evidently pays with bona fide investors to be frank.

Adequate specification is therefore imperative for the income account, as affording the most up-to-date indication of the efficiency of the management. It is no chronicle of past events, as the balance sheet may be, no recital of bygone success or error. Income accounts are downright news. They ought to be pithy, nothing less. Another 
fine example is the frank and open present-day policy of the American Sugar Refining Company, the more refreshing in view of its secretive antics years ago. The report for 1925, with comparative statement year after year since I9I I, leaves little to be desired as reflecting its rehabilitation programme. The way in which, since I916, $\$ 38,300,000$ has been expended respectively for maintenance, repairs, additions, and improvements is made thoroughly clear. On the other hand, the International Harvester Company makes no statement of the gross volume of its business, giving nothing but the income received, before deducting interest on bonus, depreciation, and like items. One cannot therefore figure what is the operating ratio or the net earning power. Likewise with the United States Rubber Company. This great concern, according to its annual report for 1925, owns I94 square miles of rubber plantation in the Far East, representing an investment of about $\$ 25,000,000$. Seven million trees, II 7 square miles under cultivation, produced $20,000,000$ pounds of rubber. Quite an undertaking, is it not? Yet this is all that is vouchsafed to the 26,898 shareholders in 1926:-

Rubber received from the plantations is taken into account by the United States Rubber Company at current market prices, and the plantations companies are credited in open account. The plantations companies draw against this open account for current cash requirements, and the balance not required for operating and development purposes is retained by the United States Rubber Company and is comprised in its general assets. The balance of the open account amounted to $\$ 7,338,305.19$ as of December 31 , 1925, and is shown in the Consolidated General Balance Sheet.

Very good paper and fair type is wasted on publication in its consolidated balance sheet of "Plants, Properties 
and Investments, including Rubber Plantations, less reserve for depreciation, \$183,861,487.64." This time, thanks be, the figures are carried out to the last penny, so that we may be assured exactly how things stand. Is n't it about time that such open-and-shut methods were brought to an end?

Fortunately the practice of issuing current statements of the course of business is steadily growing, responding in a considerable degree to the initiative of the New York Stock Exchange, beginning in 1926. A census showed that 242 out of 957 companies then listed on the Exchange were making quarterly reports, 79 were reporting semiannually, 339 issued annual statements, and 297 companies had no agreement with the Exchange respecting the issuance of such statements. Most of the lastnamed companies were engaged in transportation, subject to the requirements as to publicity of the Interstate Commerce Commission. And a number of the utility companies having no agreement with the Exchange were likewise under the authority as to publicity of the utility commissions of the various states. Steel and General Motors are foremost examples of the great concerns which report either net or gross volume of business at frequent intervals. Some of these even furnish data respecting unfilled business or other information indicative of the way the wind is blowing, as often as once a month. What an improvement this is upon the practice, so open to abuse in the past, of loose estimates or announcements and unofficial interviews by "influential directors" or officials. Yet many large companies - the American Woolen Company, California Packing, or National Lead, to choose at random - still keep their affairs a closed book until the expiration of the fiscal 
year. For newcomers, recently admitted to the list, the New York Stock Exchange now requires periodic statements in all cases. It endeavors to secure quarterly disclosure. But to attempt drastically to enforce current publicity is fraught with difficulty - difficulty sometimes inherent in the nature of the business. Little validity attaches to the objection often raised that the business is too seasonal; for comparisons of course would be sound in any case only between results for the same period of the year, never otherwise. Of uncertain force also is the objection stated by the Pressed Steel Car Company in 1904 when discontinuing quarterly statements, because perchance "on a declining market, buyers by pointing to quarterly statements of earnings may become more insistent in the matter of price." The objection that frequent disclosure is prejudicial in face of sharp competition has force, but this is greatly diminished if the practice becomes universal. For under acute competition, if the strong companies all report, silence tacitly becomes a confession of weakness - irrespective of the supreme right of shareholders to a knowledge of conditions, bright or sombre.

There are difficulties inherent in certain businesses as respects the compilation of frequent statements of net earnings. Profits of course cannot be calculated without figuring costs, and an outstanding item among these costs is that of inventory, both of raw materials and finished products. In other words, changes in the price level during the time of manufacture may be almost predominant factors in the determination of net earnings. The railroads and public utility companies which sell only service, not goods, are not bothered by this matter. Nor is the Steel Corporation, where things are 
commonly run through within a day. But with a business like the General Electric, where the manufacturing process is spread over two years, or the International Harvester Company, with its large inventory due to the slow turnover, these considerations bulk large. In the rubber or textile industries, where the cost of materials is high in proportion to the labor, conditions of the market may be all-determining. Obviously, to a completely selfcontained concern like the Steel Corporation, where everything from the ore through to barbed wire, nails, or cement is handled within the family circle, so to speak, current price fluctuations are of no account, for intercorporate profits all run anyhow to the top company. But in manufacturing not integrated thus from start to finish, the calculation of profit on net price fluctuations may become an extremely difficult matter, especially if the business be seasonal. Cotton manufacturers protect themselves by the familiar process of hedging, selling short against reserves of raw material. The National Lead Company has adopted an interesting system of equalization of reserves by which these price fluctuations may be eliminated. The Steel Corporation carries a huge reserve "set aside from earnings to absorb deflation in value which may from time to time develop." Recent experience in the rubber industry has stimulated this life-saving process. A sharp distinction, in calculating profits, between goods really finished and those only in process will often be helpful. And, all things considered, the best answer to those who object to statements of current operations is that they have been found practicable by many companies; until at the present time the denial of information of this sort to shareholders is the exception rather than the rule. The inauguration, in 
I926, of the issuance of quarterly statements by the General Electric Company, despite the peculiarly harassing complexities of its operation, is a highly commendable sign of the unmistakable trend. And why should not such information be disclosed? A monthly directors' meeting without such up-to-the-minute reports upon the table is unthinkable. Taking it all in all, the plea of impracticability bears the impress of a rather flimsy pretext. Such data could and should be formally given to the world through official channels, just as the railroads furnish their monthly statements to the Interstate Commerce Commission.

Balance sheets are prone to be inadequate or misleading in two principal respects. One is the downright omission of important items in the property accounts. Another is the failure to disclose the method of the valuation, whether it be of property or stock in trade. The leaflet report of the Standard Oil Company of New Jersey merely states that its investments in stocks of other corporations amount to so-and-so much. The president of the Baldwin Locomotive Company, at the annual meeting, issues the surprising statement that the actual value of the Philadelphia plant alone is in excess of the total of $\$ 30, \infty 00, \infty 00$, at which the entire property and equipment of the concern are carried in the accounts. No obligation seems to have been recognized to explain the matter further, although it is obviously of some slight importance to the owners of the concern. Even the railroads are still a little at loose ends in this regard. One wonders sometimes how the property account of the New York Central would look if an adequate and upto-date valuation of its real-estate holdings in the city of New York were to be recorded. Least satisfactory of all 
is the revelation of assets by some of the investment trusts - the Super-power Company, for example, or the Electric Bond and Share Securities Corporation. The latter gives merely a list of investments without condescending to give either the number of shares or specification as to whether valued at cost or market value. Punta Alegre Sugar Company for 1926 is unique in counting its chickens before they are hatched. Among assets one discovers "Planted and Growing Cane, \$3,651,579.42." Wonder what price they counted on getting! Or how they found out what the weather was going to be! Anyhow, it comes out to the last cent. And so, too, do "Organization Expenses, \$1,099,547.82"; and "Crop Expenses, 1926-27, \$1,007,467.44"; both in the same column, listed as assets. Queer what things people do! Anyhow nobody can cheat them out of their surplus of $\$ 4,457,344 \cdot 45$. That's that!

This brings us to the second important feature namely, the failure to make clear the method of valuation. In such first-class procedure as of the Pullman Company and General Motors it is plainly stated that the appraisal is based, as it should be, on cost. The Consolidated Cement Corporation frankly avows its valuation "at Reproduction Cost." But one turns in vain to many otherwise excellent statements for light as to whether the appraisal is based upon prices paid, upon the market value, upon reproduction cost, "prudent investment," or what not. The great packing concerns, now so largely publicly owned, have always been cryptic in their statements. The Federal Trade Commission in 1920 squarely criticised their inventories as invariably appraised on a market basis when sound accounting principles required a basis of cost. This criticism concludes 
with the broadside condemnation that this accounting practice "casts doubt upon all the public statements and advertisements of the great packers." Nor may there be question that the virtual theft by the bankers and the dominant stockholders from the public shareholders of the entire increment in value of their real-estate holdings in the stockyard district over a number of years, by misuse of the holding-company device in I9II, was due to a deliberate and willful failure to reflect the true state of affairs in the balance sheets. ${ }^{1}$ Whether such misrepresentation be understatement, as in this instance, or an overestimate, is immaterial for the purposes of this presentment. The wrong worked upon the shareholders and the public is as great one way as the other.

Ware of a company with a huge item of goodwill on its balance sheet! Theoretically, goodwill represents the capitalization of earning power; that is to say, goodwill reëstablishes the balance between assets and liabilities which has been upset by a face value of securities largely in excess of the tangible assets. Goodwill, in other words, is the outward expression of inward unsubstantiality. In the good old days of the so-called trusts, almost all of them were characterized by the injection of a large amount of such water. In some of them, even, - such as the United States Leather Company and the American Writing Paper Company, - goodwill equaled or exceeded the total of its real possessions. In the American Agricultural Company, "Brands, Trademarks, Patents, Secret Processes, and Special Practices" were almost three times as great as all of the real estate, buildings, and machinery put together. As a result of bitter experience, however,

1 Full details in Federal Trade Commission, Report on Meat Packing Industry, Part III, I9I9, pp. 208 et seq. 
the trend among the better sort of corporations has been in the direction of elimination of this water, inasmuch as it has been proved time and again that such overissue of securities stands in the way of financing improvements and extensions. The Woolworth Company (5900 odd shareholders), in I9I2, had nothing but $\$ 50,000,000$ of goodwill to set over against its common stock. By good management this item has now been written off down to the minimum figure of $\$ \mathrm{I}$. Under the newspaper heading "Squeeze Water Out of Ice," in 1904, is a declaration of the management of the American Ice Company. It proposed to cut its capitalization in halves. Its balance sheet, as of that date, represented goodwill at $\$ 33,000,000$ against a property account of but $\$ 7,000,000$. The management frankly stated that the capitalization was excessive, "representing no earning capacity even under normal business conditions," and that its readjustment would greatly improve the financial status of the concern. It is upon the basis of such experience that one makes use of such an item in the balance sheet as a preliminary indication of conservative practice in accounting or the reverse. For these reasons an outstanding goodwill item invites the closest scrutiny. The Goodyear Rubber Company, with "other assets, including special account and A. C. \& Y. Railroad Company and other securities held therein, goodwill patents, ... \$12,500,000" on its balance sheet, is surely describing either a holdall or a wastebasket, according to circumstances. On the other hand the B. F. Goodrich Company rigorously expunges goodwill from its 1925 balance sheet, entering its 60I,560 shares of no-par stock at $\$ 69,122,400$, "Less - Exclusion of Intangible Capital Assets; namely, Patents, Trademarks, and Goodwill, \$57,798,00I." Even General Motors 
carries a very large item of this sort, whereas the Steel Corporation at the height of its overcapitalization, twentyfive years ago, never disclosed a dollar of it according to the books. These examples of widely variable practice show what an element of uncertainty may be intruded on the balance sheet through this item of capitalized earning power.

Popular wisdom recites that all signs fail in a dry time. With corporations things work out the other way round. When they are wet, with an abundance of goodwill, commonly called watered stock, and particularly under the present widespread adoption of so-called no-par capital issues, then it is that all signs fail with a vengeance. Almost immemorial custom, until recently, started off the corporation account from a given base, a set par value, which supposedly represented either the price at which the securities were sold or else the value of the property for which they were exchanged. But nowadays, under the prevailing practice that abolishes par value, - permitting the issuance of stock, in most states, at no particular figure whatsoever, - good old-fashioned balancesheet practice has been knocked galley-west. The accounts, instead of starting from a bench mark solidly established, theoretically at least, start from nowhere, and as certainly fetch up nowhere in particular; just as little Thaddeus Flynn, along with the forces of Satan overcome by the hosts of the Angel Gabriel, in Herminie Templeton's delightful Darby O'Gill and the Good People, just took off from the edge of a cloud and disappeared into the void.

Dodge Brothers, Incorporated, representing the purchase of a well-known automobile concern in 1925, is a case in point. About $\$ 246,000,000$ was paid for proper- 
ties which were said, just as things, to be worth some $\$ 85,000,000$ net. Upward of $\$ 90,000,000$ of the total realized by the sale of its stocks to some 26,000 people stood for prospective earning power and for nothing else. It was frankly admitted in the prospectus that the capital stock of 2,850,000 shares (no-par value) "has been issued almost entirely against the established earning power, which is not assigned a value in the balance sheet." Consequently this remarkable prospectus, in the face of this statement, - or rather on the other side of the selfsame piece of paper, - represents "Goodwill" in the balance sheet at $\$$ I. It really does! Not even the almost impregnable General Electric Company, where everything in the nature of water was drastically expressed from the start, could to outward appearances exceed this performance. Each of the two balance sheets represents goodwill at $\$ 1$. They look like Siamese twins. Yet Dodge Brothers has a deluge of water, and the General Electric less than a penny. How was it brought about? By an astounding feat of legerdemain. The old-fashioned way was to accomplish such things by fictitious inflation of the assets on the balance sheet. The modern way is to bring them to pass by puncturing the liabilities. This used to be impossible, because capital stock had a fixed par value at which it went into the books. But capital stock with no par value under the laws of all but two of our states has no definable bottom. And so, among the liabilities under Capital Stock and Surplus, is this amazing item:-

Preference Stock, no par value; $\$ 7.00$ per annum cumulative; issued 850,000 shares . . . . . . . \$ $\$ 850,000$

Did ever accountants heretofore subscribe to such a contradiction in terms? This preferred stock goes in at 
$\$$ I per share, while on the same line is the promise of $\$ 7$ per annum cumulative dividends. As I figure it, this means a cumulative dividend rate of 700 per cent a year. But it is all the more remarkable that this should be allowed to go in at \$I per share, when, as a matter of fact, it was sold to the public along with some common stock at $\$ 100$ per share. And the same sort of prestidigitation is applied to both classes of the common stocks, which are entered at ten cents per share, quite regardless of the price the public paid for them. Further comment upon such an accounting monstrosity - or shall we call it acrobatics? - is superfluous.

The need, in the interest of adequate publicity, of immediate restraint upon the issuance of no-par stock, and at the same time the advantage of adoption of the independent audit, is illustrated by the Di Giorgio Fruit Corporation's annual report for 1924. This large concern, successor to the well-known Earl Fruit Company, owns or leases some fourteen thousand acres of land in the Far West, picking and marketing fruits and operating steamships for their carriage, not only in domestic trade, but to foreign countries as well. Its shareholders, to the number of many hundreds, were informed by the president, on page two of the annual report for 1924, that "the net income of $\$ 459,199.46$ for the year compares with $\$ 767,447.76$ and $\$ 471,082.69$ for the years 1923 and 1922 respectively." Turning, however, to the income account itself, one discovers that the figure just stated is the net income "before deductions shown in Exhibit B, page I8." Turning then to this Exhibit B, one learns that the "equity in net assets applicable to common stock of no par value" was $\$ 8,631,706.8 \mathrm{I}$ at the beginning of the fiscal year. But after taking out various "deduc- 
tions," depreciation, reserve for taxes, "possible further losses," and so forth, it appears that the corresponding equity in net assets at the end of the fiscal year "before taking into consideration unpaid dividends amounting at that date to $\$ 804,527.50$ on cumulative preferred stock" was $\$ 8,210,131.23$. This was $\$ 421,575.58$ less than it had been at the beginning of the same year. In other words, the book value of the common stock which has no par value dropped during the year by $\$ 421,575.58$, irrespective of everything else. This, then, is the real loss on the year's operations. It stands out rather glaringly against the apparent showing of a profit of $\$ 459,199.46$, as stated above. Anybody, of course, who was a sufficiently skilled accountant was free to figure out this result for himself. This was evidently the belief of the auditing house which appended its certification to the report; for it was clearly stated "that the profit and loss account, read in conjunction with the statement of no par value stock attached to the balance sheet [our italics], sets forth the results of operations for the year." Query: Does a statement which indicates an apparent profit of $\$ 459,000$, when as a matter of fact there was a loss of $\$ 421,000$, embody an account to which any auditor jealous to protect the interest of the real owners of the property, although drawing compensation for his services from the management, ought to subscribe? And query further: Should so bald a comparison with the results of former years properly be denominated anything else than misrepresentation? There are other significant features of this remarkable no-par stock report. Among these are the inclusion in profits of dividends of subsidiaries, earned but not declared; juggling with such items as "depreciation on appreciation," from year to year, whatever that may be; "Deferred charges for future 
operations," an item which on the balance sheet for I924 amounted to $\$ 899,679.75$. All these, moreover, are certified to by a highly reputable firm of accountants. Being only an economist, I confess utter inability to unravel it. But of one thing I am certain. Every such account and every such audit is but another nail driven into the coffin of no-par stock, as administered under the lax laws of the chartermongering states!

A corporate surplus, although it looks as solid on the balance sheet as land and buildings, can in reality be both illusive and elusive to the last degree. It may all depend upon the particular valuation of the rest of the assets; reducing inventory or writing off property may even obliterate it entirely. One of the large fertilizer concerns recently wrote up its property account upon reorganization, in order to allow an item for liberal depreciation. But even assuming valuation to be conservative, surplus may still be quite unreal, in time of need. It is n't really cash or convertible investments, even in part, however clearly it represents past earnings undistributed. For it may have become inextricably tangled up in the wheels of the business, or more likely laid down in brick and steel. Anyhow it is subject to the same risks of obsolescence or depreciation as everything else. Perhaps it is merely reputation founded upon national advertising or the like. You lean on it as on a staff, and it crumples like a weak reed. It is trick money. You try to pick it up and find it glued to the floor or somebody jerks it away on a thread. When the American Telephone Company, some years ago, took over the Western Union, it promptly wrote off as dead wood more than two third's of the surplus of $\$ 18,800, \infty 00$. It depends entirely, then, upon the sagacity and foresight of past 
management whether such a thing is rank piffle or real property.

Under the old-fashioned theory of capital stock with a definite par value, pranks enough and misfeasance a-plenty played around the matter of surplus; but with the advent of no-par stock, so often accompanied by practical disappearance of any precisely defined capital fund or estate, the doors were thrown wide open to all sorts of shenanigan. Surplus, but imperfectly distinguishable from profit and loss, has always been used to make assets and liabilities exactly equilibrate down to the last cent on the balance sheet. But now the entire capital stock, so far as it is stripped of par value, is bulked indistinguishably with the surplus to constitute such a total as to produce that same perfect equilibrium. Here is the way it reads for the National Cash Register Company for 1925 - a fair sample of newfangled accounting:-

Capital Stock and Surplus . . . . . . . \$37,856,135.08

(Represented by $I, 100,000$ shares Common " $A$ " Stock and by 400,000 shares of Common "B" Stock, both of no par value)

(Including surplus of Foreign Subsidiary Companies)

And this is one of the seven figures on the balance sheet, constituting itself alone about four fifths of the total liabilities of this great concern. Its predecessor, with a par value, indicated that this sum was about half capital and half surplus, each being handled separately. But from this time forth all distinction is airily waived aside as if it were of no consequence.

The possibilities of obfuscation, to say nothing of malfeasance, as to surplus, appear in the selfsame first annual report of 1925 of Dodge Brothers, Incorporated, 
purveying the results of its first eight months' operation under banker management. This is the way the matter is now described:-

The company's surplus at December 31, 1925, totaled $\$ 31,477,234$, of which $\$ 6,676,722$ arose upon acquisition of assets on May I, 1925, \$14,958,543 upon conversion of Debentures, and $\$ 9,84 \mathrm{I}, 969$ from earnings.

This is the same balance sheet, by the way, for which the entry of the various no-par securities into the accounts in connection with goodwill has just been described. The balance sheet itself conforms strictly to this statement. But just suppose that in this instance - and it might perfectly well have been so done by anybody else - the mere total had been stated without further specification. What a magnificent achievement to have taken the old personal corporation of April I, 1925, with its surplus of $\$ 4,608,000$, and, after adding in the actually undistributed earnings of $\$ 9,84 \mathrm{I}, 000$, to have created within eight months a so-called surplus of $\$ 3 \mathrm{I}, 477,000$. What really happened was that $\$ 15,002,000$ of debentures, standing at $\$ 100$ par each, had been converted into 434,563 and $17 / 21$ shares of Class A no-par stock, reserved for the purpose; which, as we have seen, went in on the new balance sheet at ten cents each. In other words, the net reduction in the liabilities column due to this pen-and-ink performance was approximately $\$ 15,000,000$. Taking it out of the capital stock valuation, this sum was simply shifted to the existing surplus, - the footing of assets remaining the same, - to create an aggregate about seven times as large as the surplus eight months earlier. Otherwise stated, for every time that a $\$ 100$ debenture retired, some odd shares at ten cents each stepped into its shoes - reminiscent of the rabbit sausage in the old, old story. That, too, was 
adulterated "only fifty-fifty: every time we put in a rabbit, we put in a horse." Nor is this to charge deception, in view of the frank textual avowal. Yet it stands, nevertheless, as an extreme example of the jugglery which is attendant upon some of these recent departures in American corporate finance.

The present law and current practice as to no-par stock, then, with regard to the treatment of what is called surplus is a serious menace to the holders of bonds and preferred stocks of corporations. When a corporate account is set up against assets or moneys received and fine distinctions begin to be drawn, as in the first VirginiaCarolina Chemical Corporation statement for 1926 - to cite only one of many instances - with no-par common stock which is merged with "initial surplus," all sorts of things may happen thereafter. The original conception of a surplus as an accumulation of earnings undivided in the past and which remain therefore available for distribution as dividends in the future is apt to be utterly confounded. But away behind this mere matter of accountancy, we need to stand upon firm ground as to what the real nature of even the good old-fashioned surplus was. It is illuminating to read the convincing testimony of the old auditor of the Chicago and Alton Railway back in 1907, with reference to the availability of a large surplus of many years' standing for distribution. It was his view that funds ploughed into the property by vote of the board of directors were no longer subject to draft for payment of current dividends - thus emphasizing the vital distinction between undistributed profits and surplus. But it was too late; the deed in case of his company had been done. ${ }^{1}$ Forty million dollars had been

1 Cf. Ripley, Railroads: Organization and Finance, pp. 262 et seq. 
borrowed by selling bonds, and the proceeds had been in part distributed as a special thirty-per-cent stock dividend. But it broke the back of the company in the doing of it. Perhaps he was right! At all events, we may question the wisdom of that historic New Jersey statute of 1904, which, as an aftermath of the American Malting Company decision, inserted a comma after the word "surplus" in the prohibition of dividends "except from the surplus or net profits," and so forth. This was done in order to provide that henceforward dividends might be declared from either one of two distinct funds. The bearing of this upon the subsequent American Writing Paper Company decision of 1907 was immediate.

The holding corporation is a peculiarly troublesome and confusing business as respects accounting. Even with the best of intentions it is extremely difficult to set forth the true condition of affairs, either as to the estate itself or as to the current income therefrom. The American International Corporation, for example, is largely a finance concern. It has no outstanding bonds; but its income, being derived entirely from investments, is based, so far as these investments are stocks, upon dividends which can be paid only after the satisfaction of the fixed charges of each separate company owned. Nothing less than a complete disclosure of all of these investments makes clear the financial status of the concern. Examination of the published statements of the Associated Dry Goods Corporation, which, by the way, does not even vouchsafe figures for the gross volume of its business, so that one can only make a guess as to the trend of its operating ratio, reveals how cryptic such an outgiving of a holding company can be.

The danger of incomplete disclosure is especially 
accentuated in the field of public utilities. The Electric Light and Power Corporation in 1925 asserts clearly enough that it has no funded debt; yet its subsidiaries, whence all of its income arises, have in fact $\$ 1_{4} 0,000,000$ of such indebtedness. So also with the American Superpower Corporation, which reports no funded or floating. debt. Yet its two principal investments are bonded up to almost $\$ 50,000,000$. If, with good intent, the true status may thus be obscured, how great is the danger when the morale is low. The bitter experience of United States Rubber shareholders in I9I 5 is matter of history. The United Dry Goods Company collapse, coincident with the failure of the $\mathrm{H}$. B. Claflin Company, was a public scandal. Published reports gave no indication of weakness in the top corporation, which, however, was contingently liable for over $\$ 30,000,000$ on notes of its subsidiaries. The Corn Products Company in 1903 manipulated matters another way round. A highly discouraging balance sheet was issued, cutting its surplus by over $\$ 2,000,000$. This holding company, of course, had no income of its own; so that when its principal subsidiary, the Glucose Sugar Refining Company, was caused to postpone its dividend date to the succeeding fiscal year, this, and other things of the sort, completely transformed the picture presented by the balance sheet.

It is clear, therefore, that no annual report is worth the paper upon which it is printed, without complete consolidated statements, both of income and of condition, as of a date certain. Many corporations now recognize their obligation to make conditions clear in their entirety, knowing full well that the condition of the holding company standing by itself is almost meaningless. And yet one discovers so old and important a concern as the 
Mackay Companies - not a corporation at all, by the way, but only a voluntary association managed by trustees, with a greater investment in cables to every continent on the globe than any of its rivals - confining the statement of its affairs merely" to "Income from Investments in Other Companies" with a deduction of what are virtually office expenses and taxes of the managing trust. The balance sheet consists merely of four items over and above the formal statement of the share capital outstanding. An investment of $\$ 94,000,000$ has no further explanation than that "the reserves of your subordinate companies are represented to a substantial degree by investment in government bonds and other securities of the highest class, which are availed of from time to time for the purpose of extending and improving the facilities of those companies." This takes us back to the good old days of those statements which were annually put forth by the Amalgamated Copper Company in its palmiest period. What difference in particular is there, indeed, between such practice by a highly profitable and worth-while enterprise and that old gambling affair, so far as the rights of those whose capital has created the business are concerned? Reverting to the admirable practice exemplified by the Philadelphia Company, similarly built up by a number of interlocked units, the possibility of true disclosure becomes evident.

The interrelationship between mystery and speculation is immediate. If the course of corporate events, looking ahead, could be ascertained surely by a cast of the horoscope, wagers against the future would become meaningless and unprofitable. Were all pertinent data - within reasonable limits, of course - to be disseminated as soon as available, the elements of chance and change upon 
which speculation thrives would be minimized, or at all events spread by slow stages over considerable periods of time instead of concentrated in quick jumps one way or the other. It is not merely coincidence, then, that mystery stocks are so commonly speculative in their nature. They become pawns in the great game of chance by reason of that mystery. It is interesting, therefore, to watch the transition through the speculative status into that of substantial investment as it takes place in the life history of corporations. The mind runs back naturally to the speculative orgy in United States Leather in I 899, headed by Keene, Gates, and the steel and wire crowd, to the notorious career of American Can along about I9I3, when, as we have already seen, depreciation, stock dividends, and mystery all jumbled together made its shares among the most active in turnover on the New York Stock Exchange; or rubber, which about I9I 5 manipulated its dividend rate, juggling with the floating debt of its subsidiary corporations meanwhile, so that its quotations fluctuated by as much as 30 per cent almost overnight at times. These events, coördinated with the lack of reliable data vouchsafed to the public, firmly support the proposition that mystery is indeed the mother of manipulation. The disconcerting feature of many of these occurrences was not the prevalence of public speculation - that will always occur as long as gambling and horse racing persist - but the participation by officers and directors of the corporations, commonly acting under their own name, but - as in the most notorious case of all, that of the American Ice Company, under Morse management - carrying on these transactions in the name of the company itself. The courts of course must be relied upon in last instance to impose a measure of fiduciary 
responsibility upon those charged with matters of trust. But certain things in the way of safeguards can be set up by the corporations themselves. With rare exceptions, and those specifically defined, no corporation - the American Ice Company, for example, or Dodge Brothers, Incorporated - ought to be given the charter right to deal in its own securities. And every possible discouragement should be set in the way of speculation by so-called insiders through the enjoyment of advance information. The elaborate safeguards thrown around this matter by the United States Steel Corporation are worthy of high commendation and go far to establish the integrity of the present management. It is a little difficult to decide how far, as a means of discouraging speculation, a variable depreciation policy, as in the case of many public utilities, should be used to create a greater appearance of stability in earning power than exists in fact. The announced policy of the National Lead Company a few years ago against fluctuating dividends as alluring to temporary. speculators but as deterrent to permanent investors has much to be urged in its favor. But in comparison with any other proposal, there is nothing which will contribute so substantially to stability as adequate and immediate publicity.

The influences inherent in the present circumstances and conditions of corporate existence all tend to stimulate the temptation toward speculation. Among these influences, to cite a few, the substitution of an open and impersonal market for narrow, over-the-counter, and revealed transactions; low quotations based upon no-par shares, split stocks, and the like; nonownership by directors and officers - absentee management so to speak; the very decentralization of ownership, widely scattered 
shareholders in small lots; and the secrecy and manipulation attendant upon overdevelopment of the holding company - in other words, an increasing complexity of corporate structure. Two things are happening at cross purposes with one another; namely, a centralization of industrial production in ever larger units and a decentralization of proprietorship. To hold the two in line with one another, keeping the ship on an even keel, nothing is more essential than that the spirit of speculation should be held in strict confinement. This it is which strengthens the thrust of our contention for adequate disclosure of all pertinent data. 


\section{VII \\ IMPUBLICITY \\ WHAT TO DO ABOUT IT}

THE first recourse by way of remedy for the existing impublicity of corporations is that of vigorous private initiative from within, industry by industry, taking up the issue of orderly and adequate publicity as a matter both of duty and of expediency. The street railways, for example, have long since adopted a standard form of accounting, although it seems not to be universally put into effect. A uniform classification of accounts for gas companies has been adopted officially for over twenty states. The influence of the trade associations, for the moment confined to efficiency and production data, might well spill over into the field of finance. Much that is helpful might emanate from the Investment Bankers Association of America. Much has indeed been accomplished. But one runs head-on against a serious obstacle. To a considerable degree within each industry it is a case of all or nothing. The laggard corporation, persistent in secretiveness, lays a heavy penalty upon its progressive rivals all down the line. This does not apply among public utilities, for they are industrial monopolies, more or less. But in the domain of private competitive enterprise it is only the all-powerful factor in the business, conscious of its own worth and importance, - like the Steel Corporation or the General Motors Company, which can throw reserve to the winds, making a full 
disclosure of everything. In certain industries, also, the chain stores, for instance, - where profits are derived from a multitude of transactions in different commodities, the embarrassment of disclosure is less important. Profits on all kinds of things are averaged into a general figure, not disclosed for particular products. Competition, in other words, is much generalized. But let rivalry within an industry narrow down to two or three big competitors and it takes a hardy perennial to stand the wind and weather of publicity alone.

Thus in the cracker trade, the Sunshine people, with all their thousand windows, can hardly be expected to let in the daylight, so long as the National Biscuit Company hides in the underbrush. This is the way a recent bankers' circular describes the situation:-

This company has made a practice of reporting net earnings after all expenses, interest charges, depreciation, and federal taxes. The balance sheets offer no basis for annual comparison because of the fact that net property value after depreciation as well as net inventory after write-offs are given. So far as the annual reports are concerned, no attempt can be made to show what the company is actually putting back into the business each year. Therefore, the best avenue of approach to an estimate of the real net returns of the Loose-Wiles Company is through a comparison with the National Biscuit.

Here is the situation in a nutshell: Two or three adversaries watching each other like cats spoiling for a fray, each with an eye to quick advantage over the other. How averse will any one of them be to adopt the policy of disclosure until it becomes generally recognized as "good business" so to do! Sometimes the force of example is almost electric: but until such time as the spark jumps, a heavy strain in favor of reticence is imposed. This it is which perhaps as much as anything retards the spread of 
publicity, especially in pioneer industries where everybody is feeling out a way in the dark. It has but recently been true of the automobile and the light and power businesses. It still holds good in the field of rayon manufacture, of electrical refrigeration, the baking industry, and the radio.

Beyond peradventure of doubt the New York Stock Exchange is to-day the leading influence in the promotion of adequate corporate disclosure the world over. Its evident disposition to accept fully the responsibilities of its status as the greatest organized market for securities in the world merits high praise. Its list requirements at present are immeasurably advanced beyond those of even ten years ago. It seeks to discover, first, that securities admitted to the trading list are sufficiently distributed so that there shall be a free and open market. This calls for a statement as to the ownership of the largest blocks of its stock, including the ten largest shareholders. Then a constantly elaborated questionnaire, approximating more nearly year by year to the highest standards of accounting practice, endeavors to place everything of material value upon the file. This file, it should be noted, is open to public inspection; and it is further noteworthy that the detail presented therein often greatly exceeds in specification that which is furnished to the shareholders in the published reports. For example, the Standard Oil Company of New Jersey has already been cited as distributing rather an inadequate statement of the leaflet type. But as far back as 1920 the stock-list application affords a much more complete description of the business, including such important matters as the equity earnings of subsidiary companies by name. Or for American Can, with its curt official report, there is submission to the 
Stock List Committee, in 1926, of comparative statements of earnings for the preceding five years along with a lot of other things.

The International Business Machines Corporation, in its stockholders' leaflet report, jumbles most of its possessions together as follows: -

Plant, Property, Equipment, Machines, Patents, and Goodwill, as per books, after deducting surplus of Subsidiary Companies acquired at organization . . \$28,019,035.45

A contemporary stock-list application, however, reveals that land, buildings, equipment, and machines aggregate about $\$ 6,000,000$, whereas patents and goodwill are listed at $\$ 13,700,000$. Why should not the shareholders, even more than the Stock Exchange, be entitled to know that two thirds of the listed assets, aside from inventory, represent capitalized earning power only? Oftentimes, as I am convinced is true in this particular instance, the practice is not intentionally deceptive. It springs from the impression among managements that public reports are not matters of prime importance. This view is rapidly changing, as a result of the education of public opinion. Shareholders, whether they ever scan the statements themselves or not, are entitled to the benefit in the market prices of securities which flows from the registration of significant data. That is the conclusion which deserves to be publicly posted in every exchange, and for which the New York body has been a sturdy pioneer and protagonist.

These requirements for admittance to list are steadily improving, as is also the discipline for failure to observe the conditions imposed. It is now more than twenty years since the American Steel Foundries were struck from the list for fraudulent statement of their working capital. Such downright misstatement is easy enough to deal with 
summarily. Far more difficult is it to impose drastic penalties for imperfect rendition of data or, it may be, for failure to live up to the requirements, now more and more common, of quarterly as well as annual reports. To strike the security from the list, closing the market to thousands of shareholders perhaps, would work irreparable harm. It would also shut the door upon further stimulation in the direction of sound practice, relegating the offender to outer darkness, so to speak. But the present administration is evidently solicitous to do its best. It now, furthermore, enjoys the expert attention and advice of a highly competent staff. New issues and principles are constantly arising. One of particular importance is the prevention of the use of misleading titles. A bond, to be listed as a bond, must indeed be one. And in these days of holding companies, especially among public utilities, very nice distinctions have to be drawn between things offered for sale as bonds and others which are practically notes secured by collateral which consists of stock of subsidiary operating concerns, sometimes of rather doubtful character. A participating or preferred stock must possess all the attributes of such securities, judged by the highest technical standards. Even the form of the engraved certificate must pass muster. I have in mind, for example, condemnation of the legend in large letters across the top of one of these certificates, "Stronger than the Government itself." The discouragement in 1925 of the issuance of nonvoting shares, elsewhere more fully described, exercised an extraordinarily tonic effect upon a prevailing fashion. There is a fair chance that charter provisions will be made to pass muster, to the end that those which are not consonant with public interest shall be brought into line therewith, before 
admittance to the floor of the Exchange. And over and above all these specialized activities, there is the wider educational appeal, which cannot fail to exercise a highly salutary influence upon morale all along the line.

But there are distinct limitations, nevertheless, upon the activities of the New York Stock Exchange, this best of the private agencies. Its control is restricted solely to those corporations which seek admittance to that particular exchange. There always remain the unlisted securities handled on the Curb or over the counter, as well as by the provincial exchanges all over the United States, which for many purposes are sufficient for corporations of lesser size and importance, but of the greatest diversity of standards. Unless Chicago, Boston, Pittsburgh, and the others rise to the full measure of New York in their requirements, a wide gap in supervision obtains. And it is, of course, for the lesser local corporations, more closely controlled and less susceptible to educational appeal, that the greatest need of improvement exists. Local jealousies count for something. Certain of the major public utilities with headquarters in Chicago adduce local pride as a sufficient reason for refusing "to come to New York" for an open market. Such influences, where the desire for modest seclusion as respects accounting exists, are accentuated by other motives. A security not listed - that is to say, dealt with on the Curb, over the counter, or in a provincial exchange - remains more completely under control of its own management as respects market price. But if once listed, quite apart from the obligation to file adequate data, there is the chance of having to support the stock in the open market against overt attack. For all these reasons, therefore, it is clear that, however wholesome and uplifting the 
practices of the New York Stock Exchange may be, its influence must of necessity remain circumscribed within certain rather definite limits.

Why should not the shareholders themselves, if necessary, bring about a reform in this business of publicity? Do they rest inert and mute because of sheer helplessness? There seem to be only two things which they can do. One is to boycott the sealed-up corporations. The other would be to take the bit in mouth and force the issue in open meeting. As for the boycott, mysterious corporations which have turned out to be bonanzas have always served as decoys for the public. The uninitiated are always ready enough to try a fling. But, even among the more wary, the personality and reputation of managers often afford sufficient guaranty, at all events to take a gambling chance, the more alluring because of the very mystery. The danger arises, however, from the ease with which real responsibility and power, under modern conditions, may often imperceptibly pass from strong and competent hands into others of a quite different sort. This is what is going on with great rapidity all about us at this time. And as for taking the bit in mouth, to register the opinion of thousands of stockholders is at best an expensive, difficult, and often well-nigh impossible performance. A first-class corporation, long notorious for its secretiveness, repeatedly issued statements like this, which appeared in its annual report for I90I:-

The settled plan of the directors has been to withhold all information from the stockholders and others that is not called for by the stockholders in a body. So far no request for information has been made in the manner prescribed by the directors [our italics]. Distribution of stock has not meant distribution of control. 
Surprising, was it not, that, with the characteristic inertia of stockholders "at large," they never assembled and formally preferred their requests? Was it, however, quite fair to assume that failure so to do signified approval of the official reticence?

What stockholders ought to bring about, and right speedily, too, either on private initiative or by induced legislation, is the introduction of shareholders' independent audit or of general check-up committees. Such independent auditing, at the expense of the corporation but under the supervision of shareholders entirely independent of the management, is necessary under the British Companies Act; as also in Germany. Certified public accountants report to a stockholders' committee annually, and they are held to a strict obligation at law. Whether or not, for example, a given item should be charged to capital or income account is a matter of dictation by the management in private corporations in the United States. But in England a debatable matter would be at once referred for decision to an independent executive committee of the shareholders. The object, really, would be to accomplish in the field of finance something akin to that which is expected to be brought about in the field of labor by the introduction of company unions. The principle of representation for employees by means of works councils has been widely adopted throughout our country since the war. The purpose is to establish a medium of communication between the employees collectively and the company. By and large, the relations between the two parties have been highly satisfactory, within certain limits; although it is apparent that such representation does not conform to the full ideal of the trade-union movement. In the field of ownership, too, 
it is important that the management should be tied in, so to speak, with an appreciably articulate representative body of the owners. That plans are already under way for experimentation in this direction affords evidence that a present source of disquiet and abuse may possibly be dried up by resorting to some such private initiative.

The principal difficulty is to determine the means by which election among the shareholders shall be effected. Can it be done, in fact, at all? 1

Yet another activity of shareholders in the nature of a check-up, revision, or supervision, deserves consideration. This has to do with current valuations as carried on the balance sheets. As at present conducted, such appraisals, whether in prospectuses or in annual reports, are invariably made up, not by experts of independent status, but by those whose prospects and emoluments are directly dependent upon the existing management. It is inevitable under such circumstances that these valuations should be biassed by the wish to please. Quite irrespective of artificial stimulation or suggestion, the impulse nine times out of ten is toward overstatement. We have had too many examples even of downright deception in this regard. The ill-fated New England Cotton Yarn Company in 1899 with its estimated cost of replacement of plant probably $\$ 3, \infty 00, \infty 00$ in excess of what it should have been; the American Worsted Company about I9I3 with $\$ 1,500,000$ arbitrarily injected into the appraisal; the Cast Iron Pipe Company with plants purchased for $\$ 9,475,000$ carried on the books at $\$ 24,086,000$ with no evidence of writing down for depreciation over a period of years - all this brought out in litigation in 1906; the Corn Products Refining Company in 1922

1 Already developed in detail in Chapter V, supra. 
arbitrarily revaluing its property, setting up a goodwill item of $\$ 16,000,000$ and reserves of over $\$ 8,000,000$, thereby reducing the surplus by $\$ 20,000,000$ and then in the following year writing off goodwill entirely, all to the end that the published balance sheet might present a modest appraisal of the corporate estate; - all such occurrences point to a definite and withal a perfectly simple remedy. Shareholders have a right not only to an independent appraisal by engineers at the time of issuance of a prospectus, but also to a current check by independent experts from time to time. Nor would the expense be an objection, since the cost should be chargeable to the operating expenses of the corporation. There is perhaps something for us in the United States to learn in this connection.

State legislation to stimulate or enforce publicity holds out little promise for the future. Widely differing standards between the commonwealths, already forcibly exemplified in respect to incorporation practice, bring insuperable difficulties. The pressure of local opinion in the case of important concerns can only be overcome by exercise of these powers from a distance. Heartbreaking experience in enforcement of factory legislation by local authority is of record. "If I were to attempt to execute the present law (as to child labor), this village would be too hot to hold me," was the way one of the Connecticut school visitors put it at the time. The leading instance of attempts by state legislation to invigorate business practice is afforded by the numerous blue-sky laws enacted upon the initiative of the state of Kansas in I9II. But these local commissions, serviceable enough when dealing with downright fraudulent issue of securities by mining, real-estate, or other adventurous 
companies, almost inevitably become apologetic or complaisant when confronted by serious situations in important close-by going concerns. "They are directed, moreover, against the sale of gold bricks, whereas our present concern is with the distribution of lemons," is the way one observer puts it. The Michigan blue-sky law is a case in point. The so-called Securities Commission, upon the promotion of Dodge Brothers, Incorporated, in I925, promptly rendered a forceful decision, prohibiting the sale of the capital stocks in commerce within the state. Obviously, however, over business done from New York it had no jurisdiction. Furthermore, apparently in accordance with the terms of the statute, this convincing and able statement, which if published would have clarified the whole situation, was closed to public view - at all events, I was requested to refrain from giving it public circulation. The decision merely, and not the underlying facts, obviously exercised almost no outside influence whatsoever. Such experience renders one skeptical of all local endeavor in this direction, whether like the admirable Business Companies Act introduced under Roosevelt's leadership in New York in 1900, or like the numberless blue-sky laws of one kind or another now upon the statute books. They are all good enough in their way for actually fraudulent concerns. But by way of stiffening up conditions along accounting lines in the case of ordinary industrial or commercial businesses they are bound to be practically negligible.

The utter futility of attempting to reform corporate publicity by authority of the several states is revealed by a recent eulogium of such activities by the Deputy Attorney-General of the state of New York, inquiring as to how proposed publicity may benefit stockholders, 
either actual or prospective. ${ }^{1}$ The entire point is missed of the relation of such publicity to the registration of fair prices on the exchanges. Emphasis is entirely laid upon a fancied outcry for publicity as a cure for mismanagement of corporations; "laws merely designed to investigate corporations and publish information to satisfy public curiosity, even if constitutional, are odious." Must one reiterate that the prevention of fraud, while important, is limited to a few companies; while the registration of a fair market price, consonant with the real earning power of the company, is a matter of daily and universal importance to every shareholder who may have occasion to buy or to sell securities? This instance is worth citing just to drive home the main defense of the proposed reform. And it indicates, incidentally, why the state bluesky laws, which are directed at the prevention of fraud and mismanagement, fail entirely to deal with the most weighty aspect of the matter. And then, again, as to state activity we are confronted, as always, with the lamentable diversity of morale. ${ }^{2}$ For instance, fortythree states in the Union with varying degrees of adequacy both as to intelligence and enforcement, require a license locally for the sale of securities within their limits. Delaware and Nevada, one specializing in incorporation and the other in divorce, have thus far refrained from enactment of any protective legislation of the sort. New York, New Jersey, and Maryland have merely investigation and injunction laws. The New York statute was a dead letter until 1925, but has now provision for vigorous enforcement. What happens? In the words of the Deputy Attorney-General himself, "The result of this general

1 Annals, American Academy of Political and Social Science, January 1927.

2 Cf. Chapter II et seq. 
inquisition has been apparent. A general housecleaning has ensued in the state of New York, and an exodus of undesirables to Florida, Boston, Canada, and New Jersey." Is anything further needed to demonstrate the necessity of appeal for more effective agencies than those of the individual states for dealing with the matter?

Since the early days, the experience of New York State is rather typical of conditions the country over. Corporation laws were at the outset mainly solicitous for creditors rather than shareholders. Publicity, even to the extent of setting forth in the newspapers certain data concerning debts, along with personal liability of the directors for failure so to do, was amended out of the law in 1890 , and progressively thereafter, especially in 1899 . Even the moral duty of directors to make public reports, an ancient landmark of accountability, was done away with. Not for some years did the pendulum in New York or elsewhere swing the other way. But since 1920, under the leadership of the New York Stock Exchange, the improvement in morale has been genuine and noteworthy. The influence of it has not yet, however, fully permeated the precincts of the State House at Albany.

Federal legislation providing for adequate publicity has been brought forward sporadically for years. It made its first appearance in the recommendations of the United States Industrial Commission of 1900 . This even went so far, in a minority report, as to recommend the creation of a staff of official examiners which should at irregular periods and without prior notice, as under the internal revenue laws and the banking acts, make rigid examination of the books of corporations engaged in interstate commerce. Such portions of these reports as were appropriate for public inspection were to be regularly 
promulgated through a duly constituted federal official. A less radical, and probably more practicable, proposal was embodied in a bill introduced in 1902 by Senator Hoar of Massachusetts, applying the remedy of enforced publicity to the disquieting conditions of monopoly promotion at that time. Senator Burton of Ohio in his suggestive volume, Corporations and the State, places corporate publicity induced by federal law in the forefront of his concrete recommendations for relief. The next development was the proposal of James R. Garfield, United States Commissioner of Corporations, in 1904, of a federal license law as a necessary prerequisite for engagement in interstate commerce. This recommendation of the exercise of direct affirmative power by the Federal Government was intended merely to deal with those matters which, judging by experience, could not adequately be handled by state authority. The proposal was renewed two years later by the same authority, accompanied by the following statement, which is quite pertinent to present conditions:-

The suggested federal license law will restore individual responsibility and prevent the corporation from being the hiding place of the irresponsible, dishonest, or corrupt manager. As long as the individual can hide behind a corporation, can conceal his acts upon the records of a corporation, can escape personal responsibility by means of the corporation, so long will the corporation be used as an agency for imposition, fraud, and corruption. The moment the books and records of a corporation are open to proper public inspection the danger of such wrongs will be reduced to a minimum. The corporation is not then soulless, for the individuals who control it are known, and personal responsibility for its actions can be instantly fixed upon them.

Such a law will afford a means for gaining accurate information, so that the people of our country may form an intelligent 
opinion of industrial conditions, and not be driven to extreme and unwise action by the clamor of those who assail all great corporate interests because some have done ill.

Above all, a license system will provide the most effective method for dealing with the corporation whose managers violate law, by providing that the penalty for such violation shall be the revocation of the license, and the consequent denial of the opportunity to engage in interstate commerce. Such a penalty should not, of course, be imposed without affording the corporation opportunity to appeal to the courts and obtain necessary protection against unjustifiable or improper executive action.

Comprehensive and ambitious proposals for federal incorporation or federal license to engage in interstate commerce need hardly be considered in this particular connection of adequate publicity. Whether or not on the ground of either corporate shortcomings or abuses such proposals should be advocated need not concern us for the moment. The far-reaching suggestion of President Taft by special message to Congress on January 7, I9I0, recommending federal incorporation, turned out to be politically impracticable on the one hand and economically inexpedient on the other. The immediate impulse was the decisive dissolution decrees of the Supreme Court of the United States in the Standard Oil and the American Tobacco decisions. But the foregoing developments led forward logically to the enactment of the Federal Trade Commission law of I9I4, which is still in full force and effect, as an amendment of the Sherman Antitrust law. This statute, which is usually thought of in connection with unfair trade practices and the regulation of monopoly, contains in Section 6 a positive delegation of authority to this body which is entirely adequate to the performance of the service so greatly 
needed at the present time. The Federal Trade Commission, had it chosen to exercise these powers, might since I9I4 have gathered and compiled information - to paraphrase the statute - concerning the organization, business, and management of any large corporation engaged in commerce, except banks and common carriers. Furthermore, it might require by general or special orders such corporations to file with the Commission both annual and special reports in such form as the Commission might prescribe, such reports to be rendered under oath. The record of debate upon the subject makes it clear that Congress intended this work to constitute one of its chief activities.

What is the explanation for the "innocuous desuetude" of this section of the existing law? Why is it such a stone-dead letter?. It is partly, perhaps, because the Commissioners have been legalistically rather than economically minded, preferring to institute proceedings rather than to set constructive inquiries and practices on foot. ${ }^{1}$ Another reason is that since the war, with its concomitant overdevelopment of federal power, a natural reaction against so-called paternalism supervened. A third is that this body is still in its incubatory stage of development. Even with the best of intent, it must of necessity, as did the Interstate Commerce Commission for years, fight from point to point before the courts for affirmation of its powers under the law. A prime controversy now at issue in the courts is an outcome of the rise of prices and the attendant price fixing during and since the war. The Commission, by direction of the President, had instituted special inquiries into the cost

1 A constructive assessment of the work and status of this body will be found in the 2uarterly Fournal of Economics, August 1926, pp. 561-585; and Harvard Law Reoiew, LXxxIx, 1926, pp. 694-724. 
of steel production, largely for the use of the War Industries Board. Such data turned out to be most valuable also for the Fuel Administration and for the other pricefixing or federal purchasing agencies. Congress even made special appropriations for the collection of such material. In 1920, the peak year of inflation, the Federal Trade Commission called upon the steel companies to furnish balance sheets and income statements quarterly, along with other supply and demand data every month. The account of this endeavor will be found in its report on "War Time Profits and Costs of the Steel Industry." Certain of the steel and coal companies refused to accede to these orders, on the ground that they were engaged in production and not in interstate commerce, and that they were therefore not subject to the jurisdiction of the United States in this respect. Two decisions of the federal courts have already held that the Commission had no authority for its demands. The matter has been twice argued before the Supreme Court, indicative of considerable doubt upon the point. The chances might indeed be against the affirmation of this federal authority, were it not that the final outcome in most of the trust and railroad litigation has heretofore in last resort been in favor of the plenary authority of the United States.

Various tawdry attempts have been made to give an appearance of unconstitutionality to the exercise of this power over corporate publicity by the Federal Trade Commission. It was to be expected that attorneys for vested interests would arise in protest. Nor am I overenthusiastic about strengthening the administrative arm of the Federal Government against the states. But it is expressly because it is a last resort, due to the growth of markets and of relationships coextensive with federal 
territory, coupled with impotence of the local authorities to deal with the situation broadly, that one is compelled to the conclusion that the Commission should be upheld. A recent address by Federal Trade Commissioner Myers puts it thus:-

The time is approaching when the country will be confronted with federal control of corporations as an inescapable issue. The statutes now on the books, for the most part, have to do with the regulation of the business of corporations rather than with the control of the corporations themselves. Such statutes were more nearly adequate to the protection of the public in the days when the ownership of corporations was confined to a few powerful families or groups than they are to-day. The great corporations to-day are, with few exceptions, owned by thousands of stockholders big and little; and their securities are held in every state. The protection of the competitor of a corporation and the consumer of its products is still a matter of grave concern; the protection of the investor is becoming quite as important. The diffusion in the ownership of corporate securities more than any other recent development makes federal control an issue - perhaps a necessity.

As to the constitutionality of Section 6 of the Federal Trade Commission law, above cited, which is now before the Supreme Court of the United States for final adjudication, it is true that a considerable line of cases has been decided adversely, so far as publicity is concerned. But attentive consideration of these decisions indicates that none of them thus far has dealt with the specific point at issue. This point concerns the right and interest of administrative authority to coöperate through intelligent official publicity in the determination of open market prices for securities of corporations engaged in interstate commerce which shall truly reflect their worth as based upon assets and earning power. None of these cited 


\section{MAIN STREET AND WALL STREET}

opinions touches this issue. Some, like the Armour case dealing with the packing business, had to do with powers of the old Bureau of Corporations, which antedated the Federal Trade Commission law. Some, like the Harriman case, dealt with the power of the Interstate Commerce Commission to extort evidence from persons having nothing whatsoever to do with corporations. But even here the Supreme Court disavowed any intention to decide as to what reports or investigations might be made under other circumstances. ${ }^{1}$

Taking the decisions immediately concerning the Federal Trade Commission itself, the Silverthorn Lumber case merely closed off secret, intrusive, or forcible means of acquiring information. Another group of decisions had to do entirely with the enforcement of completely different provisions of the statute. They dealt with Sections 9 and Io, which are concerned with the prevention of unfair trade competition. In the American Tobacco Company case, according to Justice Holmes, "Anyone who respects the spirit as well as the letter of the Fourth Amendment would be loath to believe that the courts intended to authorize one of its [Congress's] subordinate agencies to sweep all our traditions into the fire and to direct fishing expeditions into private papers on the possibility that they may disclose evidence of crime. We do not discuss the question whether it could do so if it tried, as nothing short of the most explicit language would induce us to attribute to Congress that intent." All such cases are dealing with government interference with business as a penalty for infraction of law. They are dealing with punitive agencies and not

1 The railroad cases will be found in Ripley, Railroads, Rates, and Regulation, p. 458 . 
with preventive ones. Still less do they contemplate the truly constructive function which might be exercised through bringing about a registration of true market prices. The Baltimore Grain Company decision of 1922 is another of these affairs which deal with abnormal situations; and the latest of all the adverse opinions, that of the Millers' National Federation, is concerned with antimonopoly legislation and not with ordinary corporate conduct at all. Nor will even the pending steel and coal cases now before the Supreme Court deal expressly with this point. They both concern the exercise of administrative power to determine costs of production with a view to governmental regulation of prices, directly or indirectly. It is quite conceivable that there are limits to this visitational or inquisitory power due to personal or corporate rights of privacy essential to the making of profits. But outside of this domain, and concerned exclusively with the publication upon a standardized and comparative basis of the general results of corporate operation, to the end that there may be a registration publicly of the comparative worth of securities upon the great exchanges of the country, there is, beyond question, a highly constructive service yet to be rendered to the general public.

Here, then, we have plainly indicated the most obvious, the simplest, the most effective remedy of all if it be necessary as a last resource to invoke the force of law. I am not covetous for the law to be so applied. But it is well to be aware that such power possibly exists. It lies inert in the hollow of the executive hand. No legislation is necessary. There is nothing revolutionary about it nothing paternalistic, to use a dreadful word, unless that means the exercise by the Great White Father of his 
lawful prerogative on behalf of some millions of our citizenry who are in need of help. Nor will it pauperize - another ill-omened word - if the President declare it to be the policy of the administration to carry out this law. Quite the reverse! Nothing will more surely conduce to popular thrift than to throw all possible safeguards about the investments of the common people. Let the right sort of appointments be made; or let the word go forth that the Federal Trade Commission is henceforward to address itself vigorously to the matter of adequate and intelligent corporate publicity, and, taken in conjunction with the helpful agencies already at work, the thing is as good as done. 


\section{VIII}

\section{OUR RAILROADS}

\section{SAFE FINANCIAL COMMON CARRIERS}

There is to-day about one shareholder in American corporations, of one kind or another, as I recall it, for each owner of an automobile in the United States. Whether this is actually so or not, is of slight consequence. Statistics are not intended primarily to tell the truth. They are uttered for the purpose of proving a point. But it is a fact, really, that there were in I 923 upward of $14,400,000$ corporate stockholders in the United States as against only about $4,400,000$ in 1900, according to the income tax returns.

What part has investment in railroads played in this great movement? There were only 800,000 such holders on the books of Class I roads in 1925, an increase from about 500,000 ten years ago. The proportion of capital stocks in the hands of the public as against those standing in brokers' names, or in corporate treasury holdings, is uncertain. But with all such allowances, the increment in the number of more or less permanent railroad share owners cannot exceed a quarter of a million during the decade. Yet there were 250,000 new names entered on the stock books of the electric light and power companies in the single year 1923. Let us emphasize the contrast a bit further! The Illinois Central, far famed for ownership among its patrons along the line, had about six times as many shareholders in 1900 as the Commonwealth 
Edison Company of Chicago. In I923, the railroad had come to have 24,000 owners; the electric light company had 42,900 - well on toward twice as many.

The Pennsylvania Railroad and the United States Steel Corporation were about even twenty-five years ago. Each has grown rapidly since that time; but the industrial concern has 35,000 more shareholders to-day than our biggest railroad. The Baltimore and Ohio and the American Telephone Company stood about even in 1900. Now the telephone has seven times as many names on its stock books. Swift and Company, the New York Consolidated Gas Company, and the Delaware and Hudson Railroad were in the same class in this regard a quarter-century back. The railroad in 1920 had 10,500 shareholders; and the other two together exceed that figure by the round number of 100,000 .

Something surely must be wrong when the greatest single industry of the United States, more dependent by reason of its geographical extent than any other country except Russia upon transportation for its general prosperity, manifests such lack of public confidence. This is the more extraordinary because railroad investments, by reason both of their high proportion of real property and of the indispensability of the service, would seem best fitted to be a safe possession of the people at large. The story of past mistakes on both sides is now an open book for all to read. But the time has come, in my judgment, to consider whether things have not so far shaped up as to warrant for the steam roads a new lease of life, financially; whether, in short, our railways may not once more assume their rightful place as a preferred repository for the savings of the common people. It has been my dream for a generation that this should ultimately come about. 
The wheel, perhaps, may not yet have completed its full turn; but if all goes well, it seems to be on the point of doing so in the immediate future.

A somewhat varied experience, private and quasipublic, has brought about many unique human contacts. One of these had to do with the preparation for the Interstate Commerce Commission at Washington under the mandate of the Transportation Act of 1920 of a general plan for consolidation of the railways of the United States into a limited number of systems. In the course of it I stumbled upon the grievous plight of a little railroad, 360 miles long, which cuts across Arkansas diagonally southwest from the neighborhood of Joplin, Missouri, to Helena on the Mississippi River. Perennially either on the verge of bankruptcy or in receivership, it has discontinued operation from time to time. Never has it enjoyed sufficient revenue to pay standard railway wages and to leave much of anything to pay even interest to the bondholders. There are many such little properties all over the United States; and the advent of the motor car has, of course, multiplied their disabilities. In this case of the Missouri and North Arkansas, however, the assertion was ventured in my official report that the road ought never to have been built through this "inhospitable" region, meaning thereby that the territory was never designed by nature to feed or support a dense population. Now the beautiful Ozark Mountain district, widely heralded as "The Land of Smiles," and emulous of becoming, as it should on its merits, one of the playgrounds of America, was deeply affronted by this slight. The state of feeling is pithily represented by the following editorial in a little local paper - the communication, by 
the way, being addressed to me at Hartford, Connecticut, indicative of a wavering doubt as to the exact geographic location of either Harvard or Yale University.

\section{That Harvard Professor}

W. Z. Ripley, head of Harvard University, in making a report on the grouping of railroads, turns his lip up at the M. \& N. A. and kicks it out of the group as a log road, or at least was built for a log road.

When we consider that a college professor is so blinded or so ignorant as to think that a railroad crossing a state diagonally and penetrating another state several miles, and when we consider that said road crosses four or five of the most important railroads in the country, then we are not surprised that the Professor's initials are at the tail end of the alphabet. We advise that the great Ripley christen his oldest son "etc."

Mr. Ripley tries to explain himself on the "inhospitable Ozarks" as he terms them, by saying that he did not have reference to the people, but to the rugged country which cannot be made to support a heavy population. Worse wrong than ever, Mr. Ripley. We can feed ourselves and the whole of Massachusetts. Come to the Ozarks, Mr. Ripley, and get beef, pork, bread, turnips, cabbage, potatoes, onions, beans, peas, tomatoes, apples, peaches, grapes, and strawberries for your cellar and your table and zinc and lead for your casket when you die, for the M. \& N. A. will not furnish the logs to "Log you in."

Now, Professor, if you are dishing out such judgment to the students of Harvard as that concerning the Ozarks and the $\mathbf{M}$. $\&$ N. A., we beg you to keep them at Newton Centre, Mass.

Such is the judgment meted out to the shrinking college teacher when he ventures forth into the domain of public relations!

This spicy incident is intended to illustrate one of the prime reasons why the railroads of the United States to-day are more nearly safeguarded against the future than they ever have been before in the course of our 
history. "It never can happen again," was the caption upon a well-known series of cartoons some years ago. Such a legend is completely applicable to the danger, formerly ever present, that ill-considered or speculative construction, for private advantage rather than in the public interest, might put the properties already in the field in jeopardy of their lives. The proviso in the Transportation Act of 1920 which requires the consent of the Interstate Commerce Commission for the undertaking of any new railroad building, while not widely advertised, will go further in the long run to stabilize and insure the capital investment in railroads now existent than almost any other safeguard which could be set up.

The importance of the foregoing provision against speculative or even merely enthusiastic overinvestment of money in competing enterprises in this field, is well exemplified in a proposal of first-class magnitude, at the present time, more fully discussed in our next chapter, to construct another trunk line between New York and Chicago. This ambitious project, brought forward by the president of the little Delaware and Hudson Railway, engages public notice, not only because of the hundreds of millions of dollars necessary to build new lines to piece out the existing mileage, but also, of course, because of its direct bearing upon the earning power and financial stability of the other through lines in the same territory. Just as those in control of the four trunk systems, existent or practically effected, have almost reached an agreement among themselves, under chaperonage of the Interstate Commerce Commission, as to an amicable partition of the mileage of this most important district, along comes this distracting proposition. And, most disconcertingly, it is reënforced by a substantial minority investment in 
various other properties which are essential to the consummation of this four-party trunk-line pact. The proposal is avowedly indefinite; it lacks many fundamentals, like provision for terminals at places like Pittsburgh; and yet its bearing upon the entire situation is so fundamental as to arrest attention. Some regard this new project as merely a gesture to affect the trading values of various indispensable parts and connections for the general plan. Whether it is or not, our immediate concern has to do with the fact that not a tie nor a pound of rail can be laid down anywhere until the proponents have proved their case. A highly competent body of experts at Washington must be satisfied; first, that there is a demonstrated need of additional transportation plants for the territory in general; second, that this need will be better met by building a new road than by amplification of the existing facilities. The preliminary report by an Examiner of the Commission staff, as to the first detail of the project, has been adverse. Evidently the matter will be most carefully scrutinized before further steps are allowed to be taken.

The curse of railroading, down to the decision of the United States Supreme Court in the Louisville and Nashville case in I9I7, was politics. For this the carriers were partly to blame. In the early days they certainly reached out for everything in sight which was to be had through favor of the Congress of the United States or of the state legislatures. If you wish to bring matters right down to date, read the report of the New Hampshire Public Service Commission for 1916 on the activities of the Boston and Maine Railroad in the internal politics of that state. Theodore Roosevelt's letter to Vice-President Sherman, of October 8, 1906, "You inform me that he 
[Edward H. Harriman] told you that he could buy the judiciary," tells the story. That is why Marcus A. Lowe, long time chief attorney of the Rock Island lines west of the Missouri River, was "for many years the greatest political power in the state of Kansas" - I quote from The Rock Island Magazine. It explains why, according to an affidavit in Daggett's History of the Southern Pacific, the affiant swore in an early political campaign in San Francisco, speaking of a brother of Senator Leland Stanford, that "the said Philip Stanford put his hand into the said sacks and distributed the said money by handfuls among the voters at said polls." Affiant was unable to swear as to how many sacks or how much money there was "because the crowd around the buggy of the said Stanford was so great." But it was always a case of "dog eat dog." The penalty, anyhow, came home to roost as a swarm of creatures battening upon the corporations. The notorious "Black Horse Cavalry," a constant threat to the New York Central Railroad, was confronted by necessity with the political power wielded by United States Senators Platt and Depew. Our Senate Chamber was over-tenanted with men like Foraker, Stanford, Cameron, and Faulkner. It was their presence which in turn opened a political career for Chandler, La Follette, and their followers.

Such goings-on are things of the past. Railroads were originally the most perfect instrumentality for service as a political machine. They were ubiquitous, all spread out and yet subject to attack at every point; thousands of contacts involving litigation compelled employment of a horde of lawyers; and in the railroad pass and other favoritism the best possible currency for use in political business was afforded. The law now prohibits passes. 
It has practically eliminated them, save for railroad employees. And the last nail in the coffin lid was driven home when the United States Supreme Court decided in 1917 that "there can be nothing private or confidential in the activities and expenditures of a carrier engaged in interstate commerce"; and that the inquisitorial powers of the government "extend to all the activities of carriers and to all sums expended by them which would affect in any way their benefit or burden as agents of the public." This shut off the railroads' activity in politics. Blackmailing politicians on their side have since been eliminated, by the transfer of all first-rate matters of business to a federal commission endowed with dignity and prestige almost equal to that of the Supreme Court of the United States.

There is only one little political cloud in the sky. That is the occasional disposition of members of Congress to bring to pass by legislation things which the Interstate Commerce Commission in the exercise of its administrative discretion has refused to permit. The proposed bill, which if enacted in 1925 would have prescribed a perfectly rigid long- and short-haul rate system for all parts of the country, affords an illustration. The sectional interest of the Rocky Mountain territory sought thereby to prevent any possible reduction in the longhaul rates of the transcontinental lines, no matter what justification might be adduced therefor. The persistence of New England Senators in pressing for legislation through Congressional act to aid the city of Boston as against the other Atlantic seaports in the matter of export rates, utterly misconceives, in my judgment, sound governmental practice.

Oddly enough, there is a certain danger, also, especially 
in the field of railroad consolidation, of the exercise of purely political pressure upon Congress on behalf of the so-called short lines, the little independent branches and feeders all over the country. There are hundreds of these. They have more political influence in the aggregate than the big Class I carriers. The reason is obvious. The great railroads are largely held under absentee ownership. Location of the property is far from the domicile of the shareholders. Not so the short lines. Each little road has on its board those prominent in the church, socially, financially, and almost every other way in the locality. Pressure from such a source threatens the Congressional member in a peculiarly sensitive way. The only safeguard against all such influences is to run up at the Capitol a wall of double steel plates from cellar to roof, electro-welded all about the edges, between politics and administrative supervision. This goal at all events is so nearly attained, after years of painful experience, as to offer great encouragement for the years to come.

The outrageous exploitation of investors, the speculation and fraud which left a slimy trail across the pages of our railway history, are matters of public record. My first contact with matters of this sort was in the public service about 1900, acting as economic counsel on railroad legislation for the United States Industrial Commission. This was an unwieldy body composed of Senators, Representatives, and public members, in reality constituted, like so many of the British Royal Commissions, to put off the evil day of responsibility for actual legislation, by solemn busy-ness at investigation. The commissioners themselves of course did not work (it was so long ago that now I can afford to tell tales out of school); but we underlings took ourselves quite seriously. I 
formulated ten specific recommendations for federal legislation, following a voluminous descriptive report. And pride in the matter is surely pardonable in view of the fact that hardly a comma in nine of those proposals was changed; and that to-day every mother's son of them is written into our federal statutes. Some of these recommendations dealing with administrative procedure, rate cutting, and reasonableness of rates became law under the impetus of the Roosevelt administration. But it was not until I920 that the capstone was set which conferred the same jurisdiction over financial practice as had so long been enjoyed by the Interstate Commerce Commission in the matter of rates. For years a practical deadlock had existed. At last it was broken and the longpostponed financial control was written into the law.

Despite the demonstrated need of better returns, even before the war period, the Interstate Commerce Commission had rigidly set its face against the granting of higher rates until it had been placed in possession of the power to control the disposition of such enhanced income as these higher rates might produce. A series of scandals, notably that of the Chicago and Alton, the New Haven, the Frisco, the Père Marquette, and the Rock Island, had disclosed the ingenuity and resourcefulness of managing bankers in enriching themselves at the expense of the public. Nor was it primarily the fact that such exploitation fleeced the unwary investor which gave most concern. The gravest harm resulted from the utter prostration, financially, of the corporation, rendering it unable to maintain proper facilities for the present or to secure funds to meet the needs of the future. Chicago and Alton stock sold at $\$ 200$ a share in the late '9o's. About 1924 it was my privilege in board meeting to make the 
motion to dispose of Rock Island holdings of such stock at $\$ 2.50$ a share. Never mind who profited or lost by such shrinkage in value! Our main concern was for the character of the service to which the public was compelled to submit, which resulted from the long-standing financial prostration of the property.

All these scandals, too, are now matters of history. The Transportation Act of 1920 not only confers full responsibility over such matters of finance upon the Interstate Commerce Commission; at the same time it relieves the carriers themselves of another grievous handicap. For this assumption of financial control by an administrative agency of the United States Government is "exclusive and plenary." That disposes at one fell swoop of a mass of harassing state legislation which had created a practically impossible condition of affairs. This relief it was, perhaps, which led to the final acquiescence in this grant of control by the then financial powers. The point to notice is that this authority stands to-day as one of the prime guarantees for the security of railroad investments. It is, moreover, an approval which looks not only at the character of the security to be issued, but also at the purpose and intended use of the proceeds.

A few concrete instances of the beneficent use of this power may not be out of order. One of the first had to do with an epidemic of proposals along about 1920, by roads with a superabundance of earning power, to capitalize their surpluses - "cutting a melon," in other words. In the old days such operations were most provocative of popular discontent, by reason of the excesses to which they were carried; but now in quick succession the Lackawanna, the Louisville and Nashville, and the 
Burlington readjusted their capitalization in a decent and orderly fashion without a whiff of popular criticism. For these surpluses were handled as they deserved to be, as a joint possession of the public and the corporation; an anchor to windward for the stockholders, and a fund upon which to draw for unproductive yet necessary expenditures for the benefit of the public. The commission stopped off, in the Burlington case, the gift of bonds for this purpose and limited it to stock; also prescribing that only a portion of such surplus might be so distributed.

New standards for sound financial practice were also the result of this new form of supervision. In the Denver and Rio Grande reorganization, a little later, three times did the plan of the bankers go back for revision, before it was able to pass muster, under official scrutiny. In another instance a well-merited rebuke was administered to the New York bankers and lawyers who reorganized the Katy. The reorganization fees were cut by upward of $\$ 800,000$. Such operations used to be scandalously handled in former times. The pending investigation of the Milwaukee reorganization is, in itself, bound to have a salutary and sobering influence. Perhaps the most notable case of all is the recent denial by the commission of the consolidation plan for the proposed Nickel Plate system in Trunk Line territory. In this instance, a hoary financial practice under a new guise, that of the concentration of voting power in the management at the expense of the ordinary shareholder, was nipped in the bud. Never have the courts dealt more vigorously to define the relative rights of majority and minority interests in a corporation. Well, indeed, may the ordinary investor contemplate the future of his little stake, resting content in the assurance that he is relieved at least from one of 
the greatest dangers of loss which beset the owners of railroad securities in the past.

Another fortunate circumstance is this: Railroad finance is peculiarly free from the newfangled devices of split common stock, served up as they have been of late in various forms. Even the no-par stock idea has made but little progress among railroads; although it has swept the boards among industrial and other public utility corporations. Only three railroads, thus far, have been permitted to adopt it. I hold it to be a dangerous expedient for any corporation, to be regarded with distrust unless hedged about with many safeguards. It has no proper place among railroads, in any event. For no-par stock is properly employed only to represent indefinitely capitalized earning power, that is to say, goodwill; and never yet has any regulatory commission, to my knowledge, acceded to the proposition that goodwill for a public service corporation was properly capitalizable at all. I look to see no-par stock, therefore, blocked off from further introduction in this domain. This will contribute to a much sounder and at all events intelligible system of accounting, especially in the make-up of the balance sheet.

Along with the sense of security attendant upon governmental financial supervision, there goes the great advantage which attaches to the existing publicity and standardization of accounts. This, too, was one of the recommendations first made by us in I9OI. It was to the effect that the standardization of accounts, both financial and operating, was as essential to common carriers as to banks in order that there might at all times be a full disclosure of the state of affairs. This is of prime importance both to the investor and to the regulatory 
agencies. The ordinary inexpert citizen, of course, may not be able to find his way through the labyrinth of figures which must be currently recorded at Washington; but he may have, always at hand for the asking, the expert opinion of economic analysts and of professional bankers. The financial status of a railroad to-day is as nearly an open book as is that of a national bankdownright fraud of course always excepted.

The following excerpt from a recent report of the Atchison, Topeka and Santa Fe Railroad is indicative of the fullness of the presentations which are made. From them one may deduce the trend of operating efficiency, the degree of upkeep of the corporate estate, and all other criteria of competent management which may be necessary. And, be it noted, all such data is compiled and openly recorded under very heavy penalties for misrepresentation of any sort.

Railway Operating Expenses

(Charged against Income Account)

Maintenance of Way and Structures

Roadway Maintenance

Ties

Rails

Track Laying and Surfacing

Station and Office Buildings

Shops and Enginehouses

Signals and Interlockers

Injuries to Persons

$$
\begin{gathered}
1925 \\
\$ 4,309,981.35 \\
3,243,691.43 \\
2,370,924 \cdot 52 \\
9,255,834 \cdot 38 \\
1,540,883.38 \\
1,070,598.84 \\
931,841.38 \\
229,121.48 \\
\ldots . . \\
\hline \$ 34,205,079.25
\end{gathered}
$$

Total

Maintenance of Equipment

Steam Locomotives - Repairs

Steam Locomotives - Depreci
Freight-Train Cars - Repairs

$\$ 15,843,406.60$

$3,061,721.21$

$13,623,913.70$

Freight-Train Cars - Depreciation
$\mathrm{I}_{924}$

$\$ 4,854,064.22$

$3,382,327.79$

$2,183,876.31$

$9,761,380.67$

2, OI $2,827.55$

$1,692,281.27$

$773,761.94$

1 $32,537.54$

$\$ \frac{\$ 6,713,084.00}{}$

Total

$\$ 18,225,384.65$

$2,958,063 \cdot 36$

$17,079,143.28$

$6,385,915.83$

$\$ 52,780,855.60$ 
Railway Operating Expenses

(Charged to Capital Account)

Additions and Betterments

1925

Land for Transportation purposes . . . . . . . . . \$2,545,168.70

Bridges, Trestles, and Culverts . . . . . . . 2,319,527.72

Rails . . . . . . . . . . . . . . . 1,575,069.42

Station and Office Buildings . . . . . . . . . . 2,056,060.02

Shops and Enginehouses . . . . . . . . I, I,989,524.66

Freight-Train Cars . . . . . . . . . 3,599,364.36

Total . . . . . . . . . . . . \$24,988,040.74

A major advantage of such standardization and publicity of railroad accounts as this under governmental financial surveillance, also, is that it affords one of the best safeguards against speculative management - direction, that is to say, which seeks to profit rather from the ups and downs of the stock market than from the steady and normal working of the plant. Speculation is the exact opposite of sound management. Speculation thrives of necessity upon change. Sound management sets its face always in the direction of stabilization. In the old days a favorite device was slowly to upbuild the property through retention of earnings which ought to have been paid out as dividends, manipulating the accounts in order to keep the secret. The general public, discouraged by nonpayment of dividends, would "let go," only perhaps to discover, too late, that plums or a melon had been ripened for distribution, unbeknownst.

The power over dividend policy and as respects maintenance and improvement, is one of the few which remain at the present time in a board of railroad directors, unaffected by any governmental supervision. Even this power, nowadays, will very likely not be allowed to be abused; in such cases, for example, as "jockeying for 
position" with a view to imminent consolidation. Publicity of accounts makes the distinction recognizable for the analyst between dividends and actual earnings. One may discover upon investigation whether the road is being "skinned" or "fattened." To this degree there has been an equalization of advantage as between the so-called "insiders" and the ordinary shareholders. It is this sharing of information which of necessity restricts the opportunity, and lessens the incentive, to railroad officials or banking managers, to play with the stock ticker, instead of attending strictly to transportation business. Is it not clear that here, too, things have distinctly looked up?

Yet another real insurance against loss is unquestionably afforded by the great experiment in physical valuation of these properties which, at a cost of perhaps $\$ 100,000,000$, has now been prosecuted since I9I4. The appraisal is drawing toward its close at last. Originally proposed by legislators who held that the railroads had been derelict in their duty to serve the public at reasonable cost, this inventory was initiated against the strenuous opposition of the carriers themselves. As the exhibits have been built up, year after year, it has become more and more apparent that honest investment and straightforward management need have no fear of the results. Only those who have created a flimsy financial structure need be apprehensive. And to date so large a number of these valuations appear to warrant the volume of outstanding securities that the original advocates and opponents of the valuation project have literally swapped sides regarding it. The whole subject is too technical to be unfolded here. It must be left with the affirmation that physical valuation under the law and the Constitution 
stands as a stalwart guardian at the portal against future confiscatory legislation or attack.

In one respect only does the railroad situation to-day appear to be unsatisfactory. Thus far the Interstate Commerce Commission has been somewhat hesitant, according to my thinking, in granting an adequate return upon these investments. This is, however, a matter which may be speedily rectified, given the necessary courage and foresight on the part of this august body. It should be said on its behalf, moreover, that under the heavy responsibility as to results which its members are compelled to bear, it behooves them to be circumspect.

They have established the figure of 5.75 per cent as a reasonable rate of return upon a fair valuation of the properties devoted to the public use. It has appeared year after year that the roads are able by reason of more efficient performance under an unchanged rate schedule to approximate more and more nearly to this figure. In I92I they earned but 3.33 per cent; by 1924 the rate had become 5.10 per cent; and for 1925 the statistics indicated a rate of 5.63 per cent. This is still approximately $\$ 25,000,000$ short of a fair return, as above defined; but it compares favorably with a shortage four years before of $\$ 492,000,000$. Conditions are evidently improving. The roads are clearly working for a living, as they should do. But they are not unlike human beings, after all. You cannot get a full day's work out of a man who has not had a square meal for a week. If we keep on growing, as a country, there is a big transportation job ahead of us. It is a pertinent question, indeed, whether we are feeding up our common carriers to fit them to carry the load.

The foregoing returns apply, of course, only to the 


\section{MAIN STREET AND WALL STREET}

country as a whole. The performance as between individual carriers is of course very uneven. Strong roads, like the New York Central, Atlantic Coast Line, Chesapeake and Ohio, Illinois Central, or Atchison, are earning so much that under the law a part of their surplus income is subject to recapture by the Government. But alongside of them are a number of sub-standard properties, which for one reason or another fall far short of yielding fair returns to their owners. Some are thus miserably circumstanced because of a bad family history or of a faulty management. Others there are, which operate under a disability peculiar to their location, structure, or the economic condition, regionally, of their patrons. This disparity in earning power under a given rate schedule can only be corrected by some process of averaging up, that is to say, by rearrangement under a consistent programme of consolidation. This aspect of the matter will be considered in the next chapter. But the disparity of earning power, not by companies but by great territorial groups, cannot thus be corrected through devotion of the surplus ability of some to making up for the deficiency of others, under some such process of equalization. When a whole district is subnormal in earnings, as the territory west of the Mississippi appears to be at the present time, there is but one way to deal with it. A somewhat higher scale of rates is inevitable - not, be it carefully noted, merely to conform to the law as a protection to investors; but in order that credit may be sustained and a satisfactory and improving service may be rendered throughout. Despite reiteration of this principle on all hands, such proposals as the Hoch-Smith resolution lately before Congress, which had for its obvious intent the holding 
down of railroad rates, demonstrate that this economic law is not yet clearly understood. For years, as I have already stated, my own interest in rigid supervision of railroad finance has been based upon the conviction that only thus can a guarantee for adequate performance be afforded. This is a matter which must be left to the Interstate Commerce Commission to determine for itself. It cannot be worked out in town meeting, in committee room, or on the floor of the Houses of Congress.

Take the case of the Western roads at the present time. They are pressing for a slight advance of rates in order that they may approximate the moderate return of 5.75 per cent. Such a rate, by the way, would be utterly inadequate to tempt capital on a large scale into any other line of quasi-public business. The telephone, electric light, and power companies, for example, are consistently granted by state authority a rate of return of almost 8 per cent. Consider for a moment what the failure to accord an adequate income entails as a result. It closes off at once all hope of raising capital for improvement and extension of facilities except through borrowing, that is to say by the sale of bonds.

It was my privilege some years ago in a book on railroad finance to point to the danger of continued resort to borrowing with its incidental burden of fixed charges, for a public service company or, for that matter, for any other line of business. And if one takes the Western roads by themselves, the disclosure of the increase in fixed charges is positively disquieting. For these roads beyond the Mississippi ten years ago were paying out less than half of their total income for interest on borrowed money. In 1924 fixed charges consumed 57.5 per 
cent of this revenue. This tendency has been in evidence for a long time, running away back to 1916 , which was for them a most prosperous time. From IgII to 1924 the fixed charges of these roads increased by more than $\$ 50,000,000$, to a total of $\$ 282,000,000$. Had their total income advanced correspondingly, all might have been well; but the income has remained almost constant, so that these fixed charges have had to come out of the net available for dividends.

Why should capital flow into an industry under such circumstances? How are the people going to abolish grade crossings, have safety train control, new union stations - all unproductive of revenue, however worth while they may be - to say nothing of double tracks, heavier rails, reduced grades, and all those appurtenances which are essential for an improved service? No longer is there danger that more ample revenues shall be diverted into the private purses of insiders, or even of the stockholders in general. The whole relationship is now open and aboveboard. If it appear that too generous a scale of rates has been provided, it is easy indeed to apply the corrective. But if the service break down through impairment of credit, no such speedy correction may ensue. It takes a long time to rebuild a property or to rehabilitate its credit when once it has been lost. Railroads, again, are not unlike human beings in that regard. Let the people at large once become convinced that the danger of financial exploitation is passed, and I am certain that they will come more and more to see, as the years go by, that their own well-being will best be promoted by the maintenance of this great industry at a high pitch of financial competence.

Two decisions of the Supreme Court of the United 
States in 1926 are of first-class importance as bearing upon the rate of return to which railroads are entitled under the Transportation Act. One is that of the Indianapolis Water Company, the other is that of the New York Consolidated Gas Company. The important point in each decision is that it affirms the reasonableness of a rate of return of 7 per cent. Seven of the nine members of the Court in the first-named case are agreed as to the reasonableness of this figure. This, it will be noted, is about 20 per cent higher than the rate of $53 / 4$ per cent which has thus far been set by the Interstate Commerce Commission under the Transportation Act. An appeal by the railroads which should overset this lower rate and substitute the figure of 7 per cent would obviously increase the maximum return upon railroad investments of all kinds in just that proportion. But this is not the only consequence of the principle laid down in the Indianapolis decision. The Court holds substantially for a rate base determined by the cost under the present scale of prices of reproducing the property. Were this reproduction valuation to be substituted for the figure just now being set by the Commission for the carriers, a figure which seems to be a composite of a number of considerations, - the result would be very greatly to increase the base upon which the higher rate of return above mentioned would have to be computed. Thus the increase would be multiplied twice over. Personally, as elsewhere stated, I hold that this theory of reproduction valuation provides but an unstable footing, helpful to railway investors in an era of high prices, but correspondingly prejudicial when prices once more return to a more normal level. But there is no gainsaying that it is pretty firmly rooted now in the law of the land, and 
that it operates to strengthen the investment value of the properties concerned.

The Transportation Act of 1920 as a piece of statesmanship is constructively as far-reaching in its importance as was the creation of the Federal Reserve System. Basically, this law laid down a new principle in rate making. It provided, theoretically at least, for income adequate for a fair return to all. But it gave no guarantee. What it promised was "a chance to earn a living by working for it." But this provision of the law required a second one, which finds its expression in the so-called consolidation clauses. For years the difficulty in establishing fair rates of return has always been that a rate which was fair for a well-circumstanced carrier might be inadequate for a less favored competitor. And contrariwise, if one sought to grant rates which would care adequately for the handicapped property, a superabundance of income would inure to the well-to-do road. These rates were always subject to shift, up to meet the needs of the indigent, down to forefend the surfeit of the overprosperous. To meet this situation the so-called consolidation clauses were enacted. But two things should be carefully noted. The first is that consolidation is not proposed primarily with a view to the realization of direct economies in operation. The second is that consolidation does not contemplate the taking from the strong to make up for the deficiencies of the weak. But consolidation as an essential to practical rate making aims to bring about competition in service between rivals which, all alike, shall have an even chance of a livelihood under the same rate schedule. It has been a source of gratification that there has been included in the proposed amplifying legislation on this point the precise language 
which I had taken occasion to use in the original consolidation report. This is in effect that consolidation shall seek so far as may be "the preservation, as between systems, of evenly balanced and effective competition, equalizing, so far as practicable, the opportunities of originating traffic and of its interchange and delivery." The statute continues, "that such systems shall be so arranged that they can employ uniform rates in the movement of competitive traffic and under efficient management earn substantially the same rate of return upon the value of their respective railway properties." I submit that under such a programme, consistently pursued, the determination of reasonable rates for each, as well as for all, at the same time will be greatly facilitated.

Relatively little has yet been accomplished in respect of such consolidation. A few properties - one or two unwisely, as I take it - have been put together loosely, thus far by a stock ownership or lease. The record, on the whole, after six years, is disappointing. The law itself was unclear as to the distinction between loose association by ownership or lease and downright merger. There was a question as to conflict of authority between state charter rights and federal law. It has seemed to me that in this latter case the Interstate Commerce Commission rather unnecessarily prejudged the case against itself. Another outstanding difficulty lay in the provision that no validation of a merger could take place, except after the adoption of a complete plan of consolidation for the whole country, each approval to. be in consonance with that plan. The practical difficulties in the way of the adoption of such a plan, arising both from its appalling intricacy and the overwhelming pressure 


\section{MAIN STREET AND WALL STREET}

of other business, have thus far stood in the way of this preliminary step.

Six years and no plan yet! The consequence: constant resort to makeshift arrangements by stockholding and lease, instead of by downright merger as was originally contemplated. To meet this situation, amendment of the law is now before the Congress. The Interstate Commerce Commission would cut the Gordian knot, by releasing itself from all obligation at law to prepare any plan whatsoever in advance. So astute a statesman as Senator Cummins prefers that the requirement of such a plan should be deferred for a term of years; and that in the meanwhile all sorts of consolidations might be validated as they arise. Only at the end of this period under this bill must all the loose odds and ends be gathered up; so that by a stated time the projected ultimate number of systems of substantially equal earning power and performance shall have been created.

In lieu of these proposals, and in the conviction that only by a rational working out of a complete consolidation programme may we bring to pass ultimate stabilization of these great investments, I venture, in conclusion, to offer a suggestion. It is this: that the requirements of a general plan for the country at large shall continue as it now is in the law, being neither repealed nor postponed, but that the practical difficulty be met by moderation of the present requirements for a complete plan, delivered in one edition, out of hand. I would permit it, instead, to be adopted piecemeal, as occasion may require. I would amend the law so that such a plan might be published by regions, with the elimination of short lines, terminals, or properties jointly owned even without the assignment of particular roads, but 
only, if you please, with the statement of general principles or policy, as the case might be. Applying this to the present Nickel Plate case, one would demand that before any validations whatsoever in trunk-line territory are granted, two primary questions should be settled. The first is whether there are now enough main stems east and west existent to provide for the future. In other words, whether or not the Delaware and Hudson project for a new trunk line, already described, is justified on the broadest possible grounds. The second question would deal with the proper relationship of the soft-coal Hampton Roads railways to the major trunk lines. Ought the Chesapeake and Ohio and the Norfolk and Western to remain lake-to-tide properties, serving all of the trunk lines neutrally, as they cross them in their course? Or may they to better effect be tied in with, and operated as part of, these trunk lines? This would require consistency in the treatment of the Pennsylvania and of the new Nickel Plate system. If the Pennsylvania might keep the Norfolk and Western, surely then the Erie-Nickel Plate system would be entitled, similarly, to tie in the Chesapeake and Ohio. But to go at the matter haphazard, allowing one trunk line to have a soft-coal Chesapeake Bay property and then to deny that right to another, would be grossly unfair. Also it might result ultimately in more discrimination as to equality of opportunity among all of the trunk lines taken together than exists even now. Here, again, as in valuation, a treatise might be written upon the subject. The problem is a puzzling one. I am confident that a way will be found to bring about this equalization of opportunity under consolidation, so that the fixing of rates at a fair level will be rendered practicable at last. 


\section{MAIN STREET AND WALL STREET}

All told, then, is there not an encouraging outlook for the railroads ahead? It was never so bright as it is now in 1927. Remember the conditions, but a few years ago, when the roads were turned back to their owners by the Government! It is almost like seeking to recall those trying days of the war when the British stood with their backs to the English Channel. It has been no mean achievement to bring these properties up to their present high state of efficiency. Only two requirements remain to be fulfilled: namely, a slightly more generous rate level, here and there, and a vigorous and consistent attitude toward consolidation. Those things accomplished, and our railroad matters would seem to have been firmly established on a secure and lasting foundation. 


\section{IX \\ PLANNING AHEAD, OR HAPPY-GO- LUCKY - WHICH?}

ON our summer farm, down in Maine, is a hill called Eagle Ridge. For nearly twenty years, about sunup and sundown, great white-headed birds have winged their way from nests in the heavy pine woods out to the sea and back, in quest of food. And they commonly pass within sight of this rocky mount, sometimes directly over it, so close that one can hear the whirr of their wings. A friend of mine has an old family place in the Lehigh Valley in Pennsylvania. Between house and barn, somewhat widely separated as they are, about bedtime each night a great aeroplane, flying low overhead, roars on its way, carrying the New York-Chicago air mail. With greater precision and more perfect alignment than the eagles' flight, in moonlight or storm, starlight or velvet blackness, it makes no difference which, this mechanical creature pursues the shortest possible course between these great focal points of our American life. It is, literally, a track through the air. The distance is only 726 miles. This is nearly 200 miles less than by way of the shortest railroad line. And some of the other routes are, roughly, Ioo miles longer than even the route of the Pennsylvania Railroad. Rather stirs the imagination, does n't it? Makes one wonder what time may bring forth! It reminds me of the school board at Lancaster, Ohio, in I828, which refused to permit the use 


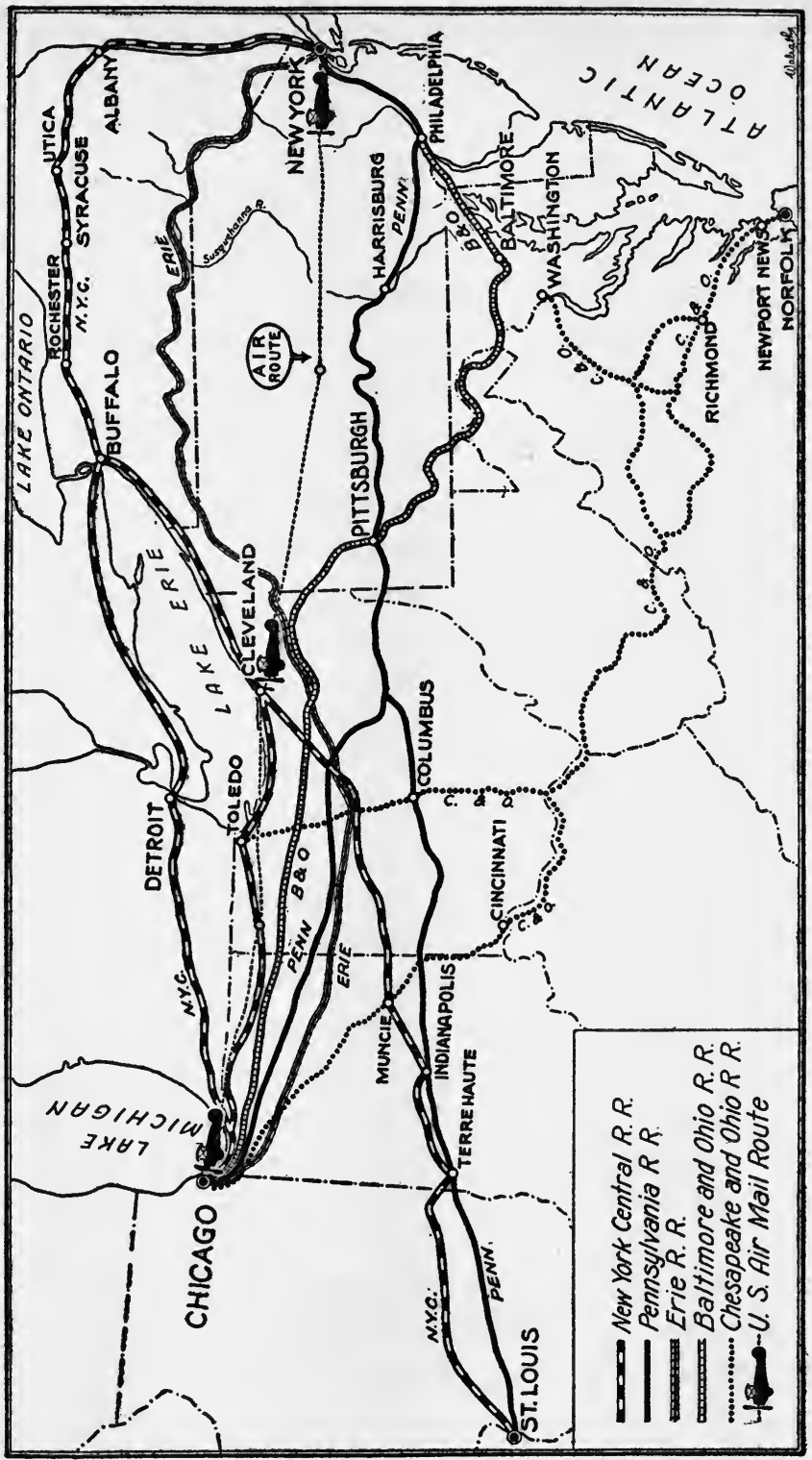


of the school building for discussion as to whether railroads were practical or not. This is what the Board said: "You are welcome to use the schoolhouse to debate all proper questions in, but such things as railroads and telegraphs are impossibilities and rank infidelity. There is nothing in the Word of God about them. If God had designed that His intelligent creatures should travel at the frightful speed of fifteen miles an hour, by steam, $\mathrm{He}$ would have clearly foretold it through His holy prophets. It is a device of Satan to lead immortal souls down to Hell."

The New York-Chicago air-mail track, then, is nearly 200 miles shorter than any rail line. This handicap against carriage by steam is explained by reference to the main map at page 256. This gives the location of the air route and of all of the existing tidewater-toChicago through systems - that is to say, carriers, which operate upon their own rails with their own equipment throughout. The Twentieth Century Limited heads out from the Grand Central terminal straightway for the North Pole. Only after I50 miles, at Albany, does it turn a right angle and go on up the Mohawk Valley to the west. The Pennsylvania runs southerly Io0 miles to Philadelphia before rounding the elbow toward Pittsburgh. Both of these routes are crooknecks, geographically. The third, the Baltimore and Ohio, roams even farther afield, swinging clear down to Baltimore, only thereafter to turn a sharp corner toward Chicago.

The Erie Railroad makes a better appearance upon the map. It alone sets forth directly upon a westward course. It follows the northern boundary of Pennsylvania out to the Lake country. Yet, while more direct 
on the map, quite a little energy is spent in traveling up and down hill and, locally, all around and about. So that in reality it is longer than either of the other two. Financially, also, it was for a long time broken-backed perennially bankrupt, and quite incompetent to serve the public effectively. All of the void on this map between these through single systems is now almost solidly packed with a number of routes in the hands of local companies, extending at the utmost as far west as Buffalo. But none of them reach beyond that point.

The causes for the foregoing wasteful layout - the absence of direct through routes - as it appears, are both geographical and political. Nature created a rugged territory west of New York. Railroading across lots hereabouts resembles human living, in a way - up and down hill work to keep going straight. North and south ranges of the Allegheny Mountains culminate in western Pennsylvania. The only water-grade breach out to the plains through these highlands was the Mohawk Valley west of Albany. Even the Pennsylvania has to make a watershed between the Delaware and the Susquehanna, as the map shows. Then from Harrisburg it follows up the Juniata Valley, surmounting the Alleghenies at an elevation of almost 2200 feet before sliding downhill into Pittsburgh. No wonder that an old placard of 1837 advertised this "Pioneer Fast Line ... From Philadelphia to Pittsburgh, through in three and one-half days."

As for the Erie's course, as the map shows, it is constrained to make two heavy hills, one over into the Delaware River valley, up in the northernmost corner of New Jersey, and then again over a divide into the upper reaches of the Susquehanna, just where the two rivers come quite close together. These geographical obstacles 
are, of course, well known. The political ones were almost as determinant. The construction of all these major trunk lines, except the Erie, was part and parcel of a great battle of the seaports for supremacy. New York city and the state backed the Vanderbilt enterprise. All the power of the Government at Harrisburg stood behind the Pennsylvania. Maryland sponsored the Baltimore and Ohio. The poor old Erie, alone, lay so closely along state boundaries and so successfully avoided all of the great cities, on its way west, that it had no political friends whatsoever. This factor alone, to say nothing of Jay Gould's malign influence, always greatly prejudiced its career.

This is the significant fact - the revelation of my whole plot - that between the Mohawk Valley out of Albany on the north and the Juniata out of Harrisburg on the south, there remains to this day a great virgin territory, relatively undeveloped for direct through business to Chicago as the airplane flies. Rail routes there are, but they are either handicapped, as in the Erie standing alone, or they are composite, so split up between connections, many of them competitors in other lines of business, as to forestall a predominant flow of traffic thereon. It is the belated appreciation of this economic anomaly by the great powers in the railroad world of today which lies at the heart of the trunk-line consolidation problem, that is to say of much of the railroad strategy of the territory. The first-class lines, so roundabout, threaten to become progressively congested with the growth of the country. They seek relief through greater utilization of the shortest possible routes. Only thus can they hope to keep pace with the development of business. The consolidation programme of the Transportation Act 


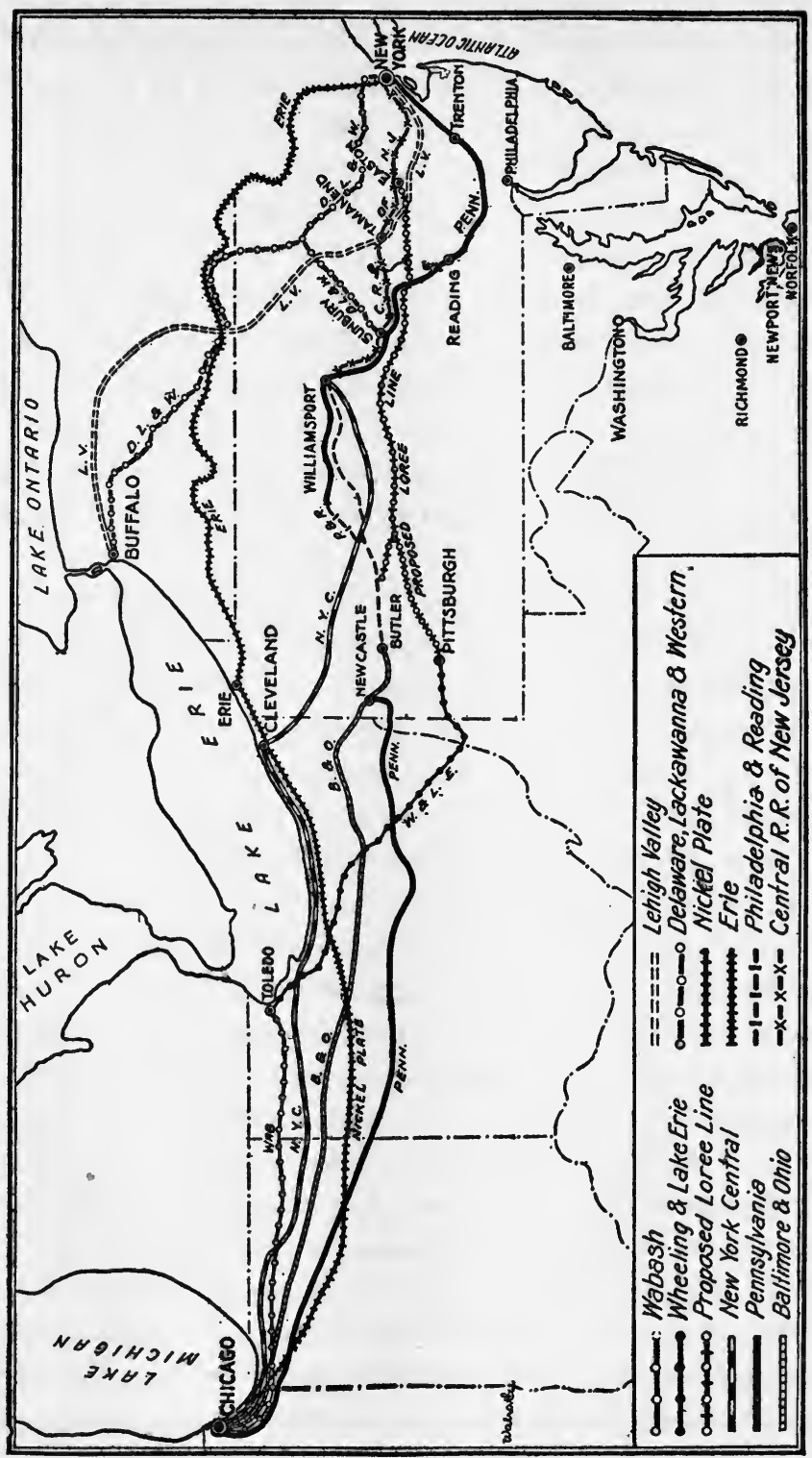


of 1920 has set them all agog, vying with one another for the possession of the existing mileage in this relatively undeveloped zone. Each one is seeking to make for itself a new and shorter rail air line by incorporating the odds and ends of disconnected and local mileage within this strategically important area.

There is a flat contrast between the underlying motives for railroad consolidation in 1925 and those which actuated the trunk lines twenty-five years earlier. In I900, after a prolonged depression and a period of acute rate cutting, all hands were agreed upon the necessity of preventing a repetition of that galling experience. The great through lines, financially well-to-do, had suffered grievously from competition of the secondary roads, many of them perennially hard up. And the most troublesome of these competitors lying between New York and Buffalo were those concerned in the anthracite coal situation.

The extraordinary natural deposits of hard coal are all in the northeastern corner of Pennsylvania, lying between the Susquehanna River, shown upon our first map, and the border of New York State. When the fuel value of this "black rock," for many years unsuspected, became known, many railroads were built into the territory in order to afford transportation to the seaboard markets. Thus came the Delaware, Lackawanna and Western, the Lehigh Valley and the Central Railroad of New Jersey, serving New York; while the Philadelphia and Reading was based upon Philadelphia. The location of their main stems is shown upon our second map, at p. 260. These roads speedily engaged in wholesale purchases of coal lands, overmortgaged themselves, and so struggled on from year to year, staggering under interest charges incurred for the carriage of their huge reserves of unmined 
coal. In due course their lines were extended to Buffalo, in order to give access to western markets for coal and, of course, to participate in trunk-line haulage as well. It was the guerilla tactics of these irresponsible poor relations in the trunk-line family which continually threatened the welfare of the first-class roads. And farther south, in somewhat the same way, the Norfolk and Western and the Chesapeake and Ohio, soft-coal properties, at heart, were "scalping" traffic, always on cut rates. The secret agreement of I900 between the Vanderbilt and Pennsylvania roads sought to insure control of all of these lesser carriers, primarily to stabilize rates and thereafter to increase profits. The question of service played small part in the proceedings.

Historically the compacts of I 900 came to naught, largely through an aroused public sentiment, culminating in Theodore Roosevelt's Progressive Party campaign for the Presidency. And during his term and that of President Taft the full force of the federal law prohibiting monopoly was brought to bear. The Harriman projects were slain in the West and this consolidation plan in the East was likewise nullified. So that about 1906 both the Pennsylvania and the New York Central dispossessed themselves of their holdings in these lesser railroads. The only heritage at present is the continuing interest of the Pennsylvania in the Norfolk and Western, and of the New York Central and the Baltimore and Ohio as equal partners in holding 43 per cent of the stock of the Philadelphia and Reading, which in turn controls the Central Railroad of New Jersey.

Thus was the ground cleared for a reopening of the whole matter of trunk-line rearrangement; when, by the act of I920, Congress reversed its entire policy respecting 
consolidation, inviting a getting-together rather than compelling a splitting apart. The underlying consideration in future was to be the promotion of service and efficiency. The rate situation having been disposed of by stabilization, under complete authority of the Interstate Commerce Commission, the keynote of the new movement became then a more effective utilization of the existing facilities. "And it is the concentration upon this principle which has brought about the interesting situation as it stands to-day. To some degree it is the advent of the motor truck, the bus, and the private car which forces the issue; but, in the main, it is the realization by all parties that it behooves them to set their railroad houses in the best possible order to meet the needs of the future. The existing mileage, yards, waterfronts, and other instrumentalities must be so allocated as to promote their most efficient use, each one as part of a system which in scope and composition shall be best fitted to serve the public need. Rivalry there should always be; but it should be an even-handed one, with such equality of opportunity for all that great and small alike shall be kept upon their toes in the only kind of competition which promotes the public interest; that is to say, the giving of service.

Public attention has been focused of late upon the rather dramatic development of the Nickel Plate system, built upon the slender foundations of an obscure little road running from Chicago to Buffalo. Under the able direction of the Van Sweringen brothers, this project for a new, through trunk line won support from the great banking powers. It promised upon completion to create a new first-class New-York-to-Chicago system. The probable success of this project and its recent rebuff at the 
hands of the Interstate Commerce Commission, purely on financial grounds, have been much in the public eye. But sight has been lost of a less spectacular occurrence carried on somewhat in chambers, but of fundamental importance nevertheless. This is the outcome of the extended hearings and voluminous exhibits in governmental proceedings on consolidation under the Transportation Act of I920. It is nothing less than an open attempt of the presidents of the four major trunk lines (accepting the Nickel Plate upstart as an equal in the negotiations) to sit around a table and to reconcile their rivalries and differences. And, curiously enough, it took place round the selfsame long oak table in the Pennsylvania's New York office on which the secret agreement of 1900 was drafted. These chiefs are seeking an agreement upon a comprehensive allocation into four great systems of all of the railroad mileage east of Chicago. To this the Interstate Commerce Commission has lent an attentive official ear. It apparently wishes them Godspeed in a publicspirited endeavor, possibly with a sigh of relief that its perennially overburdened docket would thereby be relieved of a most perplexing task.

These inter-railway negotiations have been under consideration for many months. Three of the four parties have agreed upon a programme. The Pennsylvania alone refuses its signature. A deadlock is threatened which may only be broken through the influence of the Interstate Commerce Commission. The importance of the dealings arises from the fact that more than one quarter of the rail roadway in the United States is comprehended therein. But so dense is the traffic and so multiple the trackage that probably over half the freight tonnage of the United States and certainly more than half of the 
capital investment of the American railway net are included in the plan.

And now, at a critical moment, comes the adverse decision of the Interstate Commerce Commission in the Nickel Plate case. Denial, to be sure, is purely on financial and legal grounds. Will the Van Sweringen brothers, proponents of this project, have the courage and the public spirit to persevere in their worth-while endeavor? Not alone their own plans are affected by a decision upon this point. The success of the four-party trunk-line pact hinges upon the outcome. And upon this outcome in trunk-line territory depends, perhaps, the likelihood of success for similar projects in both the West and South.

The trunk-line negotiations of 1925 have to do with a multitude of issues. The New York Central would like the Lehigh Valley road as an alternate route to its own long one by way of Albany. The Pennsylvania wishes to be assured of continued control of the Norfolk and Western. The Baltimore and Ohio, now ending at Philadelphia, has its eye upon access over its own rails to New York harbor through ownership of the Philadelphia and Reading. The Nickel Plate would like the Lackawanna to make up for some of its deficiencies; and it is ambitious to match the Pennsylvania's investment in West Virginia properties through license to absorb the Chesapeake and Ohio. But, over and above these special differences, what stands forth preëminently as a bone of contention is the provision of shorter new, through routes for all of them alike, more nearly on an air line, to Chicago. The hat was thrown into the ring somewhat dramatically at one of our consolidation hearings at Philadelphia, when announcement was unexpectedly made by the president of the New York Central that his road must be afforded 
such a direct entrance into New York in order to relieve the congestion upon the main line east of Cleveland. Appreciating the significance of this statement, the session adjourned at once. Within an hour a special train was under way, taking the jury, as it were, to inspect the landscape which had just been described.

Were you ever in Williamsport, Pennsylvania, or did you ever hear of the Catawissa Railroad? Probably not. This town has led a quiet existence heretofore, in somewhat of a backwater up northeastern Pennsylvania way. It is shown upon our second map. Just here a branch of the Susquehanna River breaks through a particularly narrow part of the Allegheny Mountain range. But the gap, alas, runs due north and south, not east and west. The Pennsylvania follows the river on one bank through this gap and goes on down toward Philadelphia. The little Catawissa Railroad, now a part of the Philadelphia and Reading, on the other bank, after following the river down to Sunbury, heads out straight for New York over the rails of the Central Railroad of New Jersey. It is as if both roads occupied and held the pass of Thermopylæ.

There are plenty of ways to reach Williamsport from the West - through broken country, to be sure - but the Catawissa line is by far the best gateway toward New'York. That explains why both the Baltimore and Ohio and the New York Central hanker for it so much. For each has a round-Robin-Hood's-barn line of its own, as we have already seen. Each stands to gain great advantage through substitution of an air line from the Great Lakes to the sea for its present crookneck course. The New York Central, by a route hereby, would bring New York seventy-five miles nearer Chicago than it now is by way of Albany. The Baltimore and Ohio would 
gain even more. Its present haul from New York to Chicago is over one hundred miles longer than the Pennsylvania and almost forty miles longer than even the New York Central. More than this, its present main line has to surmount an Allegheny summit at almost I 500 feet, about the high point on the New York Central. As for the Nickel Plate, it is out of the Williamsport picture entirely.

Our second map is intended to portray the new shortline routes which might result from coöperative handling of the existing mileage in this territory. The New York Central's interest is apparent at once. For it already has a line, as the map shows, from Cleveland in to Williamsport from the West. Given a part interest in the Catawissa branch of the Reading and the Central Railroad of New Jersey, or else rights over the Catawissa to a junction with the Lehigh Valley into New York, and it would have almost a bee line from start to finish. As for the Baltimore and Ohio, its present main line, from Chicago, according to the map, reaches Butler, just north of Pittsburgh. From that point on to Williamsport, seventy-three miles of trackage on the Buffalo, Rochester and Pittsburgh, a bit of the Buffalo and Susquehanna to Driftwood, Pennsylvania, then on the Pennsylvania, with a little new construction here and there, would put it into Williamsport.

If then, as I proposed, and the Interstate Commerce Commission agreed, the Catawissa branch and the Central of New Jersey were included in this system, the air line for the Baltimore and Ohio would also be achieved. A line for through business approximately 900 miles long could be substituted for the present haul of Ior 4 miles. 
The Pennsylvania's interest in these matters is slightly different. Its main line is not so indirect now as either of the other two; and its mileage is richly represented in northeastern Pennsylvania, especially about Sunbury, on the Susquehanna south of Williamsport. This is the end of a Lackawanna branch, as our map shows. It is a most important assembling point for anthracite coal traffic. But, unfortunately for the Pennsylvania, in order to reach New York it now has to haul this heavy tonnage round through Reading and Trenton, in a great curve, before it reaches New York harbor. What the Pennsylvania wants is a string for this bow; that is to say, a much more direct route than is now possible for some of its heaviest business. Look at the map again, and see how beautifully its interest would be served by this same coveted mileage of the Central of New Jersey, or by a half interest in the Lehigh Valley. From Williamsport west, it would connect with its own western lines, which already reach Newcastle, Pennsylvania, part of the way over its own rails, and then over trackage jointly with the Baltimore and Ohio on the Buffalo, Rochester and Pittsburgh, by way of Butler. This route, both for the Baltimore and Ohio and the Pennsylvania, would effect the lowest passage over the Alleghenies anywhere possible, except over the New York Central water-gap line via Albany.

As for the Erie, once the most nearly air-line route of the four, on the map, as it appears, it now comes last in point of distance. But by combining it with the Nickel Plate water-grade route at Erie, on the lake front, an extraordinarily effective line as respects grade and curvature would result. The old Erie, west of Salamanca, New York, had to clamber up and down over five 
watersheds between there and Marion, Ohio. But by detouring to the lake front, as the map shows, it crossed these watercourses at their debouchment, with the least possible waste of energy. What would best serve to shorten up the Erie would be inclusion of the Lackawanna, with its admirable roadbed and layout. This would set up a route only 919 miles in length, crossing the Alleghenies at a point I IOO feet lower than the Pennsylvania, and only about 250 feet higher than the water-grade line of the New York Central. Three out of the four trunk lines in these negotiations have already acceded to this allocation of the Lackawanna to the Nickel Plate-Erie system.

Now, all this strategy cannot be divorced from the question of terminals at New York. Little doubt that the covetous eyes bent upon the Lehigh Valley and the Central of New Jersey are affected by the wealth of frontage, actual and developable, in New York harbor. But that is an entirely different question and need not confuse us at the moment. It is beyond question that the provision of near air-line routes is regarded as a matter of the first magnitude. Nor can the proposition be ignored of new construction in this field. Application has recently been made by President Loree of the Delaware and Hudson Railroad for a "certificate of convenience and necessity" to build a new line approximately 200 miles in length from Easton, Pennsylvania, to Pittsburgh. It, also, is depicted upon our map. The cost would be stupendous, estimated at $\$ 140,000,000$. Nor is it yet clear just how this proposed new trunk line would reach Chicago; but, on the basis of banking affiliations, it appears as if the Wabash and the Wheeling and Lake Erie west of Pittsburgh would afford the desired connection. 
There are certain significant complications which might arise from this Loree project. The little Delaware and Hudson, important mainly as a gangplank to New England, when once separated from its valuable coal possessions, recently leased the Buffalo, Rochester and Pittsburgh, although at the nearest point their respective rails are 150 miles apart. It is the Allegheny and Western, the east and west division of this Buffalo, Rochester and Pittsburgh road, out of Butler, which, as we have seen, is so essential to the constitution of an air-line route both for the Baltimore and Ohio and the Pennsylvania. Furthermore, the banking proponents of this new line are said to control about one third of the Lehigh Valley stock. They are at the same time influential in the affairs of the Wabash. But there are many gaps between all of these dissociated parts. Two hundred miles of line at $\$ 700,000$ per mile are as yet only on paper. Much of the project is very indefinite. The preliminary report of the Interstate Commerce Commission Examiner is already adverse to the first moves in the proposed system. But one feature is clear, and that is the indispensability to almost everybody else of some of the disconnected mileage already controlled. This it is which has given color to a view that the whole proposal may have some bearing upon the sales value to its neighbors of these properties, so universally recognized as vital to a general accommodation. On this point direct evidence is of course utterly lacking. I venture no opinion of my own. The future alone will tell.

Why bother about all this intricate railroad strategy? Because it illustrates and emphasizes the need in issues of such vital importance to the whole country of positive direction and leadership by public authority. Such 
matters should not be allowed to drift, to settle themselves haphazard. Private initiative there must always be. But it is always likely to be in the nature more or less of a conflict between opposing interests, resolved by a process of give and take, of logrolling, if you please. By such means really great statesmanship is never promoted. Furthermore, deadlocks often result which may be broken only by the exercise of governmental authority. In this particular instance of the four-party trunk-line pact, the executives of three of the proposed great systems have agreed upon a programme. To this the Pennsylvania alone takes exception.

The Pennsylvania, it will be noted, has the least to gain from consolidation in any event. With rare foresight and courage, backed by unlimited resources, it has pressed forward for years, until to-day it is the foremost by far in point of extent and tonnage in this field. Well may it stand back and urge that all consolidation hereafter shall be voluntary. Such is customarily the attitude of the strong as against the plea of the weak. Far be it from me to intimate any weakness, relatively, in the present New York Central system. In many ways it functions more effectively than its bigger brother. But it is true, nevertheless, that these plans, thus far, add more to the mileage and to the tonnage of the New York Central than to the Pennsylvania. Most of all do the Baltimore and Ohio and the Erie-Nickel Plate (for I am still confident that we shall have such a system) need supplementation in order to make them even-handed competitors under a uniform scale of rates with the other two systems. And it is only when we have such an equality of opportunity that rivalry in point of service can ever be effectual. There would never be point in a 
race between Nurmi, Finland's champion runner of the world, and a man with a game leg.

This principle lies at the root of the whole policy of railroad consolidation. Adequate revenues for all can be granted only when all the participants are more or less similarly circumstanced in respect of their power to earn under a uniform scale of charges. A hostelry for princes and paupers can never economically serve but one bill of fare. No more can railroad rate regulation be run with relegation of relative indigents to an annex.

The Transportation Act of 1920 directed the Interstate Commerce Commission to prepare forthwith a tentative plan for the consolidation of the railways of the United States into a limited number of systems. It was my privilege to have a hand in the preparation of that plan. Thereafter, as the law required, the Commission, after proper notice and hearings, was to proceed to the adoption of a second plan, based upon this evidence. And no authority to merge thereafter was to be granted, except in consonance with this plan, although it was subject to modification, did the Commission so elect. Six years have now elapsed and no such second plan has yet been promulgated. No real consolidation can be legalized to-day until this step has been taken. The result is that many loose arrangements by lease or stock ownership have been approved, which virtually amount to consolidation, except for legal technicalities. They are in effect positive commitments, nevertheless. This is not as it should be, nor as it was intended. And now the Commission has proposed that it be altogether relieved by law from the obligation to adopt such a second plan, as a condition precedent to validation; and bills have been introduced which propose that consolidation shall go 
forward quite voluntarily for a term of years, only thereafter to be compulsory in accordance with any definite official plan.

Far be it from me to blame the Interstate Commerce Commission for its plea for abdication of authority in this matter. It has been overwhelmed with other duties; and in any event the requirement of a "complete plan" is enough to stagger any informed person aware of the practical difficulties. This is an apprehension I do not share. It is my proposal, already submitted in the form of a definite amendment to the bills before Congress, that instead of repealing this requirement for "a plan," it be so far moderated as to permit of easy and early compliance, as a matter of practical procedure. I would permit such planning by regions only, if you please, with omission of terminal properties and of joint or short lines if need be. I would even permit such a plan in the form of a mere statement of principles without naming particular properties. But I would still require a certain measure of foresight as to the general situation before legalizing any consolidation of particular properties whatsoever. Nor would I "treat them rough." Over in England the Government took the railroads by the scruff of the neck and put them where (as the Government thought) they belonged. There is no proposal to do that here. Merely a sign, "Stop, Look, Listen." Nothing more!

Take this trunk-line situation under review as an illustration: Here are vital matters, voluntarily negotiated, which have, however, seemingly approached almost a deadlock. How helpful indeed would it be had the Commission publicly declared itself as predisposed in the main to either four or five trunk-line systems between New York and Chicago - a decision based on careful 
examination of all of the evidence now in hand. Did it appear that there were already enough main stems in their relations to terminals to provide for future growth, that would dispose of the Loree project? If, on the other hand, open terminals for all, as in St. Louis, are to be the goal, one of the fundamental objections to this enterprise will be overcome. Is it clear that the Chesapeake Bay soft-coal roads should be tied in with the trunk-line systems, or ought they to be developed, as part of a great national system, to remain neutral, delivering coal without prejudice to all of the east and west main stems? Apparently in the Nickel Plate decision eight of the eleven Commissioners stood 4 to 4 upon large-scale issues of this sort. At any rate they still have an open mind upon the subject. One point is quite clear. All the systems ought to be treated impartially in this regard. If the Pennsylvania is to retain control of the Norfolk and Western, why may not the Nickel Plate be allowed to retain the Chesapeake and Ohio? All these great questions of national importance deserve consideration in the biggest possible way. How can they be so considered except by some planning ahead?

Another advantage of a certain amount of planning ahead is that it gives a cue in advance to those of initiating mind; while yet it may effectively discourage what are known as "hold-ups" for personal or private advantage. Horse-trading or steam-roller tactics are out of place in this domain. These are matters of high diplomacy. It is dignified and proper that the Government should assume leadership. Planning should be tactful and coöperative. That goes without saying. It should take the form of a gentle push here, a warning there. It should encourage private initiative, not oppose obstacles. 
But always it should be made clear that it is the interest of all which must predominate over any possible advantage to each.

How futile to expect success in engineering or business without such careful forethought and without real headship! The very prestige of the Interstate Commerce Commission - the most important and influential body at Washington except the Supreme Court of the United States - is involved in this business. The reputation of this body is now at high-water mark, in view of its recent demonstration of courage and insight in the Nickel Plate case. It is the due function of these eleven men, collectively, and it should be their pride and boast, to retain a clear status of leadership in this matter of consolidation - more important in its broadest aspects than any other transportation issue which may arise in the course of our history. 


\section{$\mathrm{X}$}

\section{MORE LIGHT}

\section{AND POWER TOO!}

ThE development since the World War of public utilities other than railroads, and particularly of the electrical branches, has been phenomenal. The capitalization of the electric light and power companies, which in I9I9 was approximately equal to that of iron and steel, at the present time has increased to about $\$ 7,500,000,000$, as compared with $\$ 4,000,000,000$ for this other basic industry. The increase in output, measured by kilowatt hours, during the decade just closed has been almost fourfold; until over half the population of the United States at the present time is in the enjoyment of electricity for lighting purposes, to say nothing of three fifths of the entire output which goes into manufacturing, mining, and irrigation. Within the decade preceding 1924, electrically driven horsepower in manufactures rose from less than $9,000,000$ to over $22,000,000$. These figures are sufficiently staggering; but they are exceeded in measure of development by the increase in public ownership of these utilities during the same period. In 1918, the shareholders in gas, electric light, and power companies numbered $1,250,000$ - practically double the number of stockholders in railroads and allied transportation service. The railroads have been growing for almost a hundred years; these other activities hardly more than a third as long. Yet in 1925 there were 3,160,000 
stockholders in the electrical industries, as compared with less than $1,000,000$ in railroads. This impressive total of over three million shareholders, whose interests are bound up in the welfare of this great industry, is deserving of the most attentive consideration - particularly in view of the fact that the vast majority consist of little investors, largely customers and employees, many of whom are indulging in their first experience in thrift and investment.

The extreme youth of this lusty upstart, its bumptiousness even, suggests the drawing of a parallel with human experience. For industries are like mankind in their development. Youth is a period of experimentation, of trying one's wings, of ebullience, generally untempered by experience. Industries, like human beings, may in the time of their adolescence sow a wild oat or two, only to sober up and steady down in later years. Time in all these things is the important thing. It brings assuaging accommodations. In art, as in life, it softens tones and even griefs. Moss grows on tiles; flowers bloom on graves. New things may be raw, rude - whether in taste, as wine; or colors, as in painting. So also with laws, governments, business practice. Excrescences are worn off, corners rounded, outlines smoothed. Of such also are the tolerations, through lapse of time, in friendships and in marriage. Things gradually get put into place, find their equilibrium. Such has been our national experience with railroads. We are in midstream of such accommodation in the great problem of urban living. It is little wonder, therefore, that in this young and sturdy industry, still preserving all confidence in its basic soundness and its certain future, there will be things which one might wish otherwise; there will be tendencies which, 
if not restrained, will entail grave danger, not only to the industry or its owners alone, but perhaps throughout the wider domain of public contentment and security. Is it not a time, then, aptly to quote that "House Divided" speech of Lincoln's - scarcely second as a national deliverance to the Gettysburg Address: "If we could first know where we are, and whither we are tending, we could better judge what to do and how to do it"?

All else pales into insignificance by comparison with the political aspect of the business. The recent shocking disclosures before the United States Senate Committee on Campaign Fund Expenditures indicate that we stand face to face once more with the same sinister influences which for so many years beclouded the relation of the railroads to the people. The parallel is perfect. Every last detail of the ignoble transactions is the same. Moore, political agent, on the stand; the president of the Commonwealth Edison and the Middle West Utilities Company under discussion: $\mathrm{He}$ "telephoned me to come to his office and when I went there he said he wanted to aid the Smith campaign. He said: 'When you want the money, come and get it.' Each time he handed the money over, a package of bills in an envelope. It was all in currency." Such contributions of $\$ 193,734$ were matched by others from a dominant owner of the Central Illinois Utilities Company, and from the Chairman of the Board of the Western United Gas and Electric Company and the Western United Company. Such transactions have always been put through in money. The last payments on Boston and Maine participation in New Hampshire politics in 1910 were also in currency, sent by express from the president of the Concord and Montreal Railroad. The financial contributions of the Louisville 
and Nashville "for creating public sentiment," $\$ 59,000$, were by similar means, personal or otherwise, concealed.

Note again in these recent disclosures, Brennan, this time a Democratic political agent, on the stand: "He called me on the telephone, and I went over and he said: 'Old fellow, don't you want to see me before I go to Europe to-morrow? I want to give something to you even though I am a Republican."' That resembled the old New Haven Railroad, under Mellen, who testified that his road had no politics - its efforts were merely directed "to get under the best umbrella." Jay Gould used to say that the Erie Railroad was "for the Democrats in Democratic counties in New York; for the Republicans in Republican counties; but at all times and places for the Erie Railroad." After years of persistence, culminating in the Supreme Court decision of 1917 in the Louisville and Nashville case, these pernicious practices were brought to an end; partly by the aroused moral sense of the industry itself, partly by the affirmation of the inquisitorial power of the Interstate Commerce Commission over all accounts, books, and even personal correspondence. Must we go through the same experience again with this new industry? There is a good deal of evidence to the effect that these recent disclosures are exceptional. But whether they are so or not, it is certain that all such practices must cease. They strike at the very root of our political institutions. The integrity of our legislatures and of our courts depends upon their utter eradication. And again, as with the railroads, we have the same two remedies. Will the leaders of the industry, standing shoulder to shoulder, take high resolve that "such things simply are not done in polite society"? Will they make common cause for their 
uprooting? Or must we again resort to the power of the law through the creation of regulatory and inquisitorial administrative agencies? Either one or the other, or both, must surely be invoked in the common good. The perpetuation of the American republic demands it.

There is, however, one novel circumstance in these recent Illinois political disclosures in that Smith, since elected to the United States Senate, in whose aid the principal contributions by these public utilities were made, was at the time Chairman of the Illinois Commerce Commission, before which all matters of rates, finance, and operation come up for determination. Not merely prospective favor, therefore, was being flagrantly purchased, but existing administrative influence. Governmental discretion and authority were outrageously undermined by covert bribery. Another, more subtle political menace may not be ignored in this connection. One of the men dominant personally in the industry observed to me one day, speaking of the new Public Utility Legislation in Florida, "Of course, this law will not harm us. How could it? Our own people wrote it." To restrain such influences of the lobby in our state and national legislatures constitutes an entirely different problem from the prevention of downright bribery and corruption in elections, yet a problem not less important.

A striking phenomenon of the last two years has been the active promotion of new combinations or substantial enlargement of the existing systems. In addition to several thousand small isolated plants, there are now, roughly speaking, three hundred company systems which serve populations in excess of 25,000 each. The growth of the small independent plants seems to be keeping pace 
with the development of the country; but this disposition to aggregate into far-flung territorial combinations is the outstanding event of the last two years. The large central power stations, of which in 1925 there were about IIO, produced approximately nine tenths of the total output. Most of these are now subsidiaries of large holding companies, and more or less the core of the greater systems. But among all of these, large and small, a boiling, seething rearrangement is continually going on, generally for purposes of efficiency and economy; but also, as it appears, too often for the profit incident to the turnover. A recent census indicates that during 1925,560 of these electric properties were involved in this movement; 153 of them as absorbing companies, and 407 incorporated in the larger systems. One quarter, in fact, of the aggregate capitalization of the electric light and power industry was represented by the properties acquired during this twelvemonth. The largest was a transaction involving $\$ 200,000,000$; three involved over $\$ 125,000,000$, and twenty-one were in excess of $\$ 25,000,000$ of capitalization. So far has this movement progressed, that five of the largest holding companies, alone by themselves, in 1925 controlled 43 per cent of the national central station output.

Typical of the largest of these electric light and power systems is the so-called Insull group, covering almost half the states in the union, with a part of Mexico, and representing about II per cent of central power generation. It was the presiding genius of this combination who casually remarked to me that he was "personally responsible for one thousand million dollars of other people's money." The smallest of the five major systems, Standard Gas and Electric, served 
I I 90 communities and a population in excess of $5,500,000$ scattered over nineteen states of the Union in 1925. This smallest one turned out 5 per cent of our central station output. Within the last year it has added very greatly to its reach and power. Another of the giant combinations, Cities Service Company, covers nineteen states and part of Canada. It serves 3,000,000 people, living in 600 communities. American Waterworks and Electric Company is outspread over sixteen states. Some, like the North American Company, specialize in great strategic plants in the large cities, while National Public Service is typical of the sort which spreads itself out rather thinly in the less thickly settled districts. Some are built upon the plan of all stock ownership of subsidiaries; others, like Electric Bond and Share, simply own enough securities to insure a flow of management and supervisory business to support the holding corporation financially. Some, as we shall see, drive their subsidiaries abreast, all the reins running to a single driver's hand in the chariot. Others, for reasons which will appear, string them out in tandem, one after the other interminably. Some are inherently strong, with a sound financial structure; others are inherently strong despite it. Some have played their hand through weakness into strength; others seem to be slipping. But in and through all of this ramification of detail there is, by and large, this constant disposition toward aggregation and operation on a scope which greatly transcends the territory or the controlling power of any of the single states of the Union.

Nor has the combination movement stopped with the erection of these single great systems. There is now in evidence a still further supercombination movement, 
somewhat resembling in community of interest the developments in railroading twenty-five years ago. The United Gas and Improvement Company, one of the biggest and oldest systems, in 1924 joined hands with the Insull interests in common control of different systems. In the superpower combination, one discovers representatives on the directorate of the leading systems all over the country. In New England, the Northeastern Power Company, superposed upon the Insull interests in the northern half of New England and the New England Power Company in the southern half, may bring to pass what will amount to an effective and monopolistic control of the entire region. Throughout this consolidation movement one detects tendencies toward excess which are disquieting. There are instances clearly of overreaching, that is to say, of purchase in order to gain a foothold or to block the plans of competitors; and elsewhere in the maze of intermingling companies, wastes of transmission suggestive of carrying coals to Newcastle revive memories of what happened in the railroad field. A central station in State A is seeking to do business at long range in State $B$, while coincidently a rival central station grounded in State B is reaching out across State A, picking up plants here and there. The long heads and the wise heads are of course producing compact, well-ordered systems, adequate to bring about the desired economies. But others are putting these properties together as the railroads were sometimes linked up in the old days, rather for the purpose of profiting on the turnover than because of economic advantage to be gained from the merger.

In the assessment of this consolidation movement one seeks to apply certain well-recognized tests of operating 
or financial soundness. A great deal has been said about diversification as a means of insurance against disaster; and it surely is of advantage that through holdingcompany organization an investment in urban properties should be set over against others in rural communities; that an investment on the fruit-raising Pacific slope should be tied in, perhaps, with others in the corn belt, the wheat regions, or the cotton-growing South. Drouths and shortages in one region may find compensation through bumper crops or notable industrial activity in others. But this advantage of diversification may be easily overestimated. Not merely widespread geographic dispersion affords a safeguard. To have properties in one part of the wheat belt or the cotton region tied in with others, several states removed in distance, but still dependent upon the selfsame price of cotton or the same world's market for wheat, affords no true insurance through diversity of investment - spreading the risk. Here again, as between systems, one detects wise and discriminating policy on the one hand; or, on the other, an apparently ill-considered purchase and incorporation of anything in sight which could be had for a price. Gigantic forces are evidently at work, fighting for position. Strategic rearrangement is in the air. Some of the recent struggles for possession of the field in the Carolinas, for instance, and in New England, are reminiscent of the active period of railroad consolidation early in the century, like the titanic struggle between Hill and Harriman for the Deschutes canyon on the Pacific slope, or competitive building to tie in Los Angeles direct with Salt Lake City.

Scientific analysis of the electrical industries calls at the outset for a clear understanding of the distribution 
of costs of production. A typical case is that of the rates recently fixed by the Massachusetts Department of Public Utilities for the Boston Edison Company. Of a rate of eight cents per kilowatt hour to the consumer, not more than one cent was held to represent the cost of generation of the electricity itself, the remaining seven cents, less return on the investment, standing for the costs incident to distribution to the consumer. This assumption of one cent per kilowatt hour, as a possible manufacturing cost by steam production, appears to be certainly warranted for the large central stations. In another Massachusetts case, question being raised as to the ability of the modern Montaup Station to sell to the Fall River Company at I. 3 cents per kilowatt hour, the reply of the engineer was: "I think it will be lower than that . . . I think we have produced it at a figure very close to one cent, if not below that, with the Montaup plant in operation ... a large and efficient plant, with a good load factor." For power delivered wholesale, the rate of production will of course be substantially lower, as in the sale by the Commonwealth Edison Company of Chicago of two thirds of a billion kilowatt hours to the Electric Railways at three quarters of a cent. On the other hand, where municipal plants, as at Seattle, put in rates for private consumers at substantially lower figures delivered, this ratio of generation to production cost of one to seven would be essentially modified. The point, however, is not to define precise percentages, but to emphasize the fundamental principle that a very large proportion of retail electrical costs has to do, not with making the "juice," but in transmitting it from the bus bar to the point of consumption.

The relative distribution of costs will vary, of course, 
according to circumstances, and it is in fact open to many qualifications when practically applied. In the Edison case above mentioned, for example, who shall say how much of the seven cents arbitrarily allocated to distribution, as distinguished from generation, is in reality required to compensate for excessively low rates to consumers who have been served below cost? Some of these may be potentially independent plants, department stores, for example, practically headed off from self-reliance by the grant of abnormally low wholesale rates. Others may be the numerous small consumers who in fact cost more than they contribute, by virtue of the pettiness of their consumption. But with all such allowances, it seems reasonably clear that the expense of generation for retail business is relatively small as compared with that for distribution. In this regard, the electrical industry resembles that of petroleum. The whole early history of the Standard Oil Company was conditioned by the fact that the cost of disintegrating the raw oil into its component parts was insignificant as compared with the expense of subsequent transportation to the consumer. Intense preoccupation with railroad rates, and the erection of the Standard Oil monopoly through manipulation of these railroad rates, are now matters of economic history. This analogy for students of transportation gives zest to the examination now in hand. Now see what happens as we follow it through.

The first conclusion based upon the foregoing analysis is that there are definite limits to the scope of electric light and power combinations - a point beyond which any conceivable economies in generation of power are bound to be outweighed by the wastes of transmission. This is especially true in rural transmission over thin 
territory, where the stepping down of the voltage for local consumption from the high tension necessary for long-distance transmission is an important element to say nothing of the expense of maintenance, troublehunting, and collections in sparsely settled regions. The Secretary of Commerce has uttered a note of warning in regard to the necessities for territorial limitations and the advisability, through state administrative agencies, of scrutinizing and disallowing consolidations, unless an economic advantage can be clearly demonstrated. Nash, in his Economics of Public Utilities, puts this pithily: "Some of the dreams of the uninformed advocates of superpower cannot be realized ... Relay plants and the cost of long transmission lines commonly take away much of the advantage of hydroelectric power over steam, leaving only a fraction of a cent per kilowatt hour to represent the reduction which can be made in the rates charged to users of service. This is a very small proportion of the total cost of rendering retail service, the major part of which is made up of carrying charges, taxes, expenses connected with distribution, services, metering, accounting, and administration."

An intimation of a second conclusion is afforded by the first. A wholesome corrective is needed for the impression, industriously disseminated through selfinterested propaganda, that these widespread electrical consolidations now under way are likely to bring about corresponding economies; and, therefore, commensurate reductions in consumers' rates. For, obviously, superpower, that is to say interconnection between electrical stations, may not at best accomplish more than to lop off a part of the relatively small generating cost. It may indeed produce economies, as we shall see, through 
reduction of the necessary investment; but it does not touch the large proportion of the total expense, which has to do with transmission and delivery. For wholesale production of power, and with a high variability of load, of course, the savings in investment to meet the peak load through interconnection may be very great. They constitute a prime incentive toward wholesale hooking-up of contiguous companies. But even this economy may be overestimated. This caution has been recently confirmed by experts of the National Electric Light Association: "Superpower has thus accomplished for electricity users the furnishing of service at practically pre-war prices, while these same increased costs have greatly increased the prices of all other necessities. . . . While further improvements will undoubtedly be made, bringing with them gradual reduction in costs and rates, no such radical cuts as are sometimes prophesied in irresponsible articles may be looked for." That dead line somewhere near one eighth of the total cost of production sets the bound for public aspiration in this regard.

The third conclusion, and by no means an unimportant one, although it has been pertinaciously suppressed, for obvious reasons, is the possible economy for retail purposes of the smaller generating station at or near the point of consumption, over large central station plant. Granted that these "teapot" or "peewee" plants, even under the best of conditions, generate at a disadvantage, their losses on generation may be far more than outweighed through the prime economy incident to proximity to the market. There are in Massachusetts to-day perhaps sixty small municipal plants which are effectively serving their communities, at rates quite reasonable by comparison with those made by the great centralized 
corporations. There is a continued and healthy growth in the number of public and private electrical plants all over the country, which is due to the operation of these same influences. Repeated attempts, as it appears, to bring about scientific inquiry and discussion of this question have been deliberately thwarted by some of those who have a major interest at stake in the promotion of the large-scale operations. Convincing testimony is at hand of resort to steam-roller tactics for the annihilation of technical discussion of matters of this sort. Furthermore, evidence is not lacking, as in a recent Massachusetts case, of the granting of unduly low rates to large consumers, in order to bring about the abandonment of such projects for the installation of private generating plants. But, of course, the truth is bound in the long run to prevail in these matters, and where, as in Massachusetts, long-time contracts contemplating such suppression or tending to perpetuate uneconomic rates for overlong periods are likely to be drawn, the desirability of the most searching scrutiny in this regard, as a matter of public policy, is fully recognized.

A distinction, in economic analysis, must obviousiy be drawn between hydroelectric developments and those attendant upon other branches of light and power service. This is especially true of comparative costs for small steam plants in contradistinction to large central stations. Hydroelectric development involves a huge initial investment with its attendant fixed charges, which go on regardless of the load factor; whereas the small steam plant can vary its costs somewhat in proportion to utilization. The hydroelectric plant produces no byproduct like heat. All of Harvard University, for example, is heated by the exhaust, that is to say, the waste 
steam, from the nearby Boston Elevated power plant. In applicability to mining, or where especial flexibility is required, the hydroelectric plant must also be considered as a thing by itself. And even, as between hydroelectric development and the large central stations, the cost initially of the former may be from two or four times as much as for the modern steam-generating plant. The disability of hydroelectric operation on the New England rivers, for example, by the New England Power Company arises from the necessity not only for the generating machinery, but for huge storage basins to compensate for seasons of low water. Steam generation furthermore has perhaps even greater prospective economies than have characterized the notable developments of the last twenty years. For the hydroelectric-plant conditions are already so simple as to generation as scarcely to hold out comparable hope for still further efficiency. This is perhaps but the offset for the almost total absence of labor cost characteristic of this type of development.

The advantages of holding-company organization have been persistently and elaborately set before the public for a decade. They are substantial and convincing up to a certain point. Mere recapitulation must suffice, particularly to indicate that practically each merit has its attendant defect, by virtue of the abiding motive of selfinterest. The distinction between sheer operating functions and those appertaining to finance, as well as the difference between engineering, technical, and business activities, must be continually kept in mind. Types shade into one another. Many of these concerns are merely "quasi-investment companies" - to quote the president of one of the largest among them. Such a 
concern performs no operating function at all. But, by and large, these are the obviously serviceable attributes:-

Holding companies afford a wide distribution of business risk, although the extraordinary inherent stability of earning power, said to be independent of prosperity or depression, somewhat minimizes the relative importance of this advantage. Secondly, more skillful administration, both on the business and on the technical side, at low cost, through coöperative effort; perhaps best illustrated by the first-class organization of the Electric Bond and Share Company. On the business side, the purchase of supplies at wholesale. Large-scale centralized financing, by volume rather than piecemeal, through this highpowered vehicle of finance-sometimes, as it appears, a bit over-engined. Economies in power production through provision of large central stations, with interconnection for minimizing investment to meet peak load or emergency. Concentrated and more effective public relationships, dealing with regulatory bodies and consumers, publicity flying squadrons, and more competent legal staffs.

Unquestionably, also, as in the formation of the Engineers Public Service Company, there is greater defensive power for resisting the stock-purchasing onslaught of competitors. As the subsidiary companies stand back to back, perhaps in closed-up, trust formation, like the New England Power Association, there is safety in numbers against attack. And finally it is alleged that subsidiary properties can be rearranged more readily: buying and selling corporations - passing them, that is to say, from hand to hand. A mere statement of these advantages will suffice to call to mind the shadow cast by each. The dean of the industry, Mr. Samuel Insull, defines the 
holding corporation's task thus: "to strengthen and guide the local companies." Guidance raises the question of direction, too - merely another way of stating that every virtue has its attendant vice. And of course one may also register the query in general as to how far many of these advantages are peculiar to the holding corporation, not being attainable through downright merger in single corporate units.

Having viewed the face of the coin, reverse it and give thought to certain defects of the holding corporations, glaringly in evidence at the moment. Roughly, these are four. First, admitting the principle that one corporation may own stock in another, such license to hitch in tandem may run on to infinity. There is no end to it. The door is open to unlimited corporate extension and complexity. Secondly, the same thing is true of control, thereby making it possible for a small fraction of the actual investment to dominate management for all the rest. This summarily cuts the ground from under the basic principle of our civilization: that ownership and control, working in unison, afford the best guaranty for the permanence of our institutions. A third danger is the double shuffling and bandying of corporations about from hand to hand without suitable corrective let or hindrance. The utter obfuscation of accounts, almost inevitable in these involved set-ups, is another defect, and the public aspect of it, evasion or indirection in matters of regulation and rate making, cannot be overlooked. These several defects may be well illustrated by a few concrete instances.

Herewith are three typical public utility hierarchies, large and small, illustrative of modernist extension practice in the field of public utilities. 


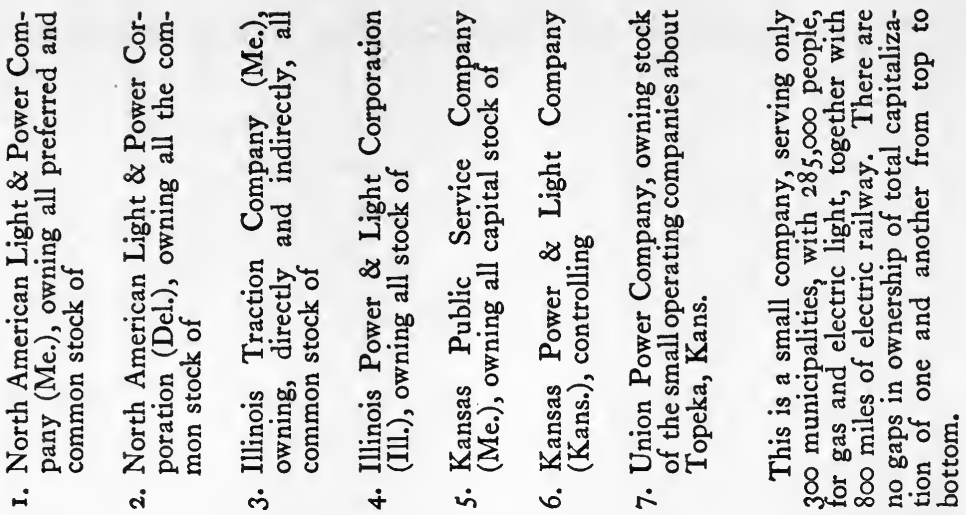

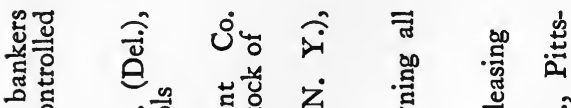

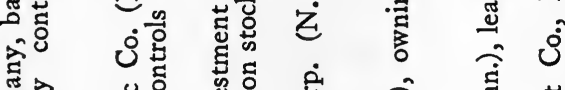

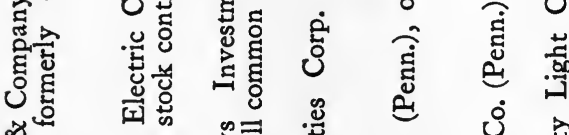

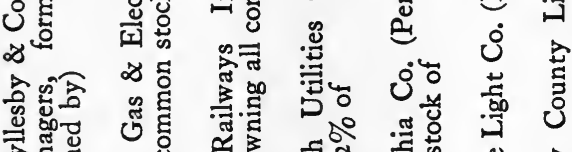

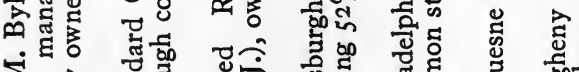

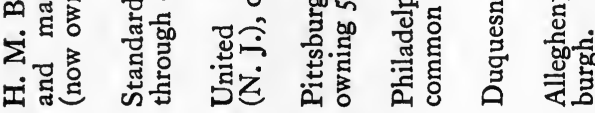

喜高

$\sum_{\infty}^{\infty}$

边.

ㅇํำ

कृ

कू 8

.

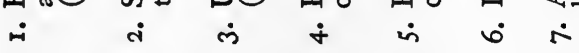

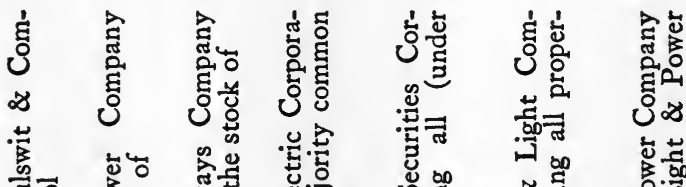

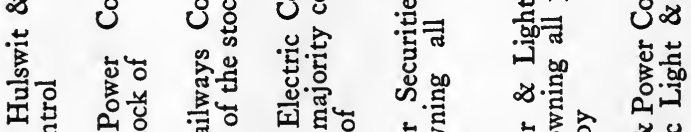

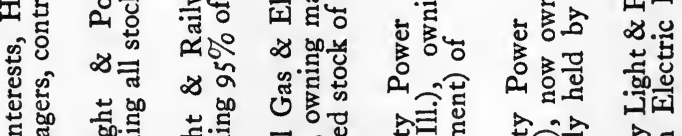

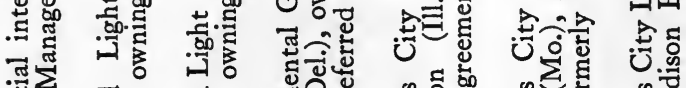

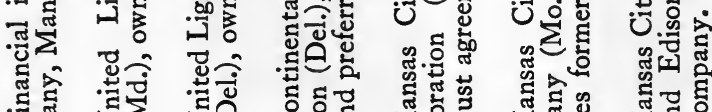

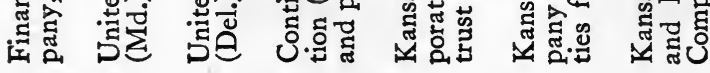

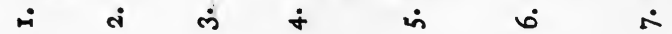

की

ชั

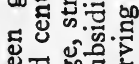

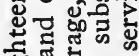

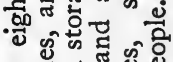

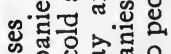

象苋苋8

ถั แ. तี

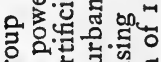
क力口十 놇

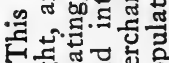

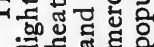


In the days before corporate jazz, the Rock Island Railway set-up of I900, which imposed two holding companies upon the operating property, was regarded as downright scandalous. But that was almost a generation ago. Here we have six piled one on top of another, and the practice is so common as to arouse no gossip whatsoever. It will be noted, furthermore, that these heapedup concerns are not loosely held by ownership of a bare majority of stock. That feature is a phase of concentration of control. This one, characterized by heaped-up corporations bound together by ownership of all the stock, is distinctively an American development. Nor can the phenomenon be fairly laid upon the doorstep of the industry itself. It is an outcome of our federal form of government, and of the conditions under which these companies, pursuing their "tramp and bauble existence," - to borrow a phrase from the Supreme Court of Kansas, - are spawned. The keynote is found in the variety of states, indicated in the exhibit, which have a hand in their forthputting. Thus, as Abraham Lincoln once said, in enumerating the assets of a client of doubtful standing, "Last of all, there is in one corner [of the office] a large rat hole which will bear looking into." Nonuniformity of state corporation laws, however, is no rat hole. It is as deep as a well and as wide as a church door, and, as experience shows, "' $t$ is enough."

Is n't it queer how these corporate hierarchies seem to peter out after attainment of a seventh-degree unfolding? What magic is there in that figure seven? We have it in the seven-day week, the ecstasy of the seventh heaven, the healing powers of the seventh son of a seventh son, and the reputed rejuvenation of our bodies every seven years. These even suggest, for the moment, poor mortal 
man with his existence of threescore years and ten. In the Northeastern Power Corporation family circle - nor yet by reason of strength, either - is the only case thus far discoverable of an extension of a corporate holding genealogy to fourscore, exceeding the set limit of seven. And thus far this strength gives evidence of being but labor and sorrow. One is inclined to sympathize heartily with Mark Twain on a certain occasion - "not a bit superstitious myself, but I always did hate to sleep thirteen in a bed."

That Northeastern Power Corporation is indeed an apposite example of amazingly complicated involution. What a gulf there is between the consumer of gas who is served by the Municipal Gas Company of Albany, New York, and the real head of the concern. All of the common stock of the gas company is owned by the Mohawk Hudson Power Corporation. A little less than 20 per cent of the stock of this company is in the treasury of the Power and Electric Securities Corporation. Then the Power Corporation of New York in turn owns all the common stock of the Power and Electric Securities Corporation, but all of its preferred shares are held the other way round, that is to say by the Mohawk Hudson Power Company. This introduces a slight complication. Nor does the Power Corporation of New York stand upon its own feet; because a large proportion of its common shares in turn are owned by the Northeastern Power Corporation, the top company. Then the serpent swallows its own tail in part because some 75,000 shares of the Northeastern Power Corporation are owned by the Mohawk Hudson Power Corporation, which has already been described as standing about halfway up this extraordinary genealogical tree. But that is only half the 
story, which is too complicated to be fit to print. When one enters upon the ramifications of the New England Power Association, the New England Power Company, the Connecticut River Power Company of New Hampshire, and so on, each one of these seems to be owned by and yet to own a substantial block of the shares of the other. It would turn the hair of a Philadelphia lawyer gray to disentangle these relationships. We used to think that the pedigree of some of the traction companies in the city of New York was a trifle involved; but this mass of corporate involution puts that early achievement entirely to shame. And every day adds to the record of absorption of hitherto independent public utility companies in its long list of communities like Albany, Utica, Hartford, and Oswego, which are being comprehended.

Utility managements are less to blame for this overextended situation than are the people of the United States. Corporations are oftentimes compelled by the diversity of state laws to resort to these artificial arrangements - albeit perhaps not without a modicum of quiet satisfaction that our conflicts of laws are so baldly permissive of profitable indirection. Thus many states require that public utilities be conducted by domestic corporations; else they may be denied the enjoyment of such rights as that of eminent domain. Hence the domestic operating concern has to be controlled by a holding corporation chartered elsewhere, in order to couple up these local privileges with others which may alone be attainable by going abroad. A case of Jack Sprat and his wife "and so betwixt them both they licked the platter clean!" The Minneapolis General Electric would forfeit its charter were it to transfer its properties to a foreign corporation. The only thing to do is to keep it alive and hold its stock 
from elsewhere, catch as catch can. Minnesota also lays a double liability upon stockholders in public utilities. Marketability for Northern States Power stock would be impaired thereby; hence one markets customer stock of a holding corporation, elsewhere chartered without this double liability. Indiana may require a vote of 75 per cent of the stockholders of an Indianapolis public utility in order to validate a mortgage. Utilities, Power, and Light can perhaps corral only 7I.4 per cent of the stock. Off we go to Virginia for a charter creating an intermediary corporation, which proceeds, not to mortgage the property, but to mortgage its holdings of stock in the corporation which does hold the property. Sometimes, it must be confessed, these complications are the outcome of inconsistencies between the financial fashions of different eras; or of the incompatibility of one company with another. Anyhow the mix-up is just as confusing.

Shall we call it whipping the devil round the stump, or is it a case of the house that Jack built, and all that? Still further to build up a record, some domestic corporations have to be kept alive because of bond issues outstanding, perhaps with sinking funds. No accounts save minute books are kept, but they go on like brooks almost forever. Maine permits resort to steam-roller tactics in winding up corporations, allowing condemnation proceedings to compel recalcitrant minorities to fall into line. It is also quite complaisant about releasing its corporations from any approval of transactions by majorities or specific fractions of given classes of stock, each voting by itself. Under certain conditions a Maine charter might be convenient for a holding company, that it might the more freely traffic in subsidiaries. The marked preference of Electric Bond and Share Company for State of 
Maine charters might perhaps be thus explained. The New Jersey Board of Utilities, partly as a result of our nonvoting-stock campaign in 1926, has recently condemned a voting trust for control of an interstate bus line. Query: Why not, as they do on local buses in Rhode Island, back down a bit over the Massachusetts line, in order to get a good fresh start on a local run to another point in Rhode Island, because, forsooth, a cargo of interstateness is thereby taken on? The similarity of names, where these corporations are driven by pairs, Twenty-Mule-Team-Borax fashion, is still further confusing. Northern States Power Company of Minnesota has another of Wisconsin close alongside; the Kansas City Power and Light Company of Missouri is yoked with a corresponding Kansas City Light and Power Company of Kansas - titles twisted tail-end-to, or perhaps one a Company and the other a Corporation. It is the Middle West Securities Company one day, and then, presto! it is the Middle West Utility Company. Only Alice, with adequate legal counsel, in Wonderland could do justice to such a situation. It all seems so witless and tortuous, this conflict of state legislation, over taxes, no-par stock, and every other conceivable issue; and to it there is no end. Rather, we are irresistibly trending to one of two goals: either greater unanimity of state legislation, or supersession of state incorporation for interstate business, by direct intervention of federal authority.

A homely and possibly diverting illustration which would make this abstruse legal situation clearer would be afforded by the careful citizen, called upon, let us say, to transport a package of T.N.T. or some other high explosive across the city to his domicile. Down by the river, where mists and damp prevail, there might be need 
of a waterproof wrapping; passing a conflagration, a covering which would be fireproof would seem desirable. The package might well be rendered heat-proof for subway transportation. And it is conceivable that in the neighborhood of a great power plant or, in case of a thunder storm, complete insulation against electrical disturbance would contribute to one's peace of mind. A lead covering or whatever else may be necessary against intrusion of X-rays or the lately discovered deadly emanation from the cathode might in time be necessary. Each local contingency would call for a specific wrapping, and the whole would constitute a rather cumbrous affair. Or, put it in terms of the human body, if you will. The cautious citizen would enwrap his person in mesh underwear against heat; a sweater against the cold; a mackintosh against rain; white clothing for sunlight glare and black for obscurity; and perhaps withal a bullet-proof vest or full armor, together with a diver's suit to meet all possible contingencies. Such panoply, absurd as it may seem, closely corresponds in theory to the corporate involution of our public-service companies under the American system of conflicting and yet concurrent state jurisdiction.

The awkward and even deceitful nature of these involved corporate relationships is fully recognized by responsible managements. Several first-class attempts, in fact, are now under way, aiming at a simplification of such overextension. The outstanding instance, perhaps, is that of the Standard Gas and Electric, as shown upon our exhibit on page 293. This attempt at simplification through substitution of direct ownership from a single holding company of the various operating concerns is an outcome of the recent acquisition of the involved public 
utilities of San Francisco and Pittsburgh. General Gas and Electric has also recently directed its attention toward the acquisition of practically all the securities of a number of subsidiaries, to the end that the top corporation may thereafter own the common stocks of its operating concerns directly, driving them all abreast, so to speak, without resort to these intermediary holding concerns. And as part of its attempt to unify its financial set-up, Associated Gas and Electric is engaged in a similar praiseworthy endeavor, whatever one may think of the new plan, just as a bit of finance. This, just by the way, strikes one as more than a bit labored and cumbersome.

Holding company organization is highly provocative of unwarranted concentration of power, well defined by Lyon as "controlling not the ownership of the operating concern, but controlling the control of the operating concern." First off, holding corporation A may control the operating company by ownership of $5 \mathrm{I}$ per cent of its capital stock. If thereupon corporation $\mathrm{B}$ controls corporation A by ownership of a like bare majority of its common shares, the investment necessary to swing the entire enterprise is again practically cut in halves. And so on ad infinitum. This use of the holding corporation differs essentially from the one previously described, wherein the hierarchy is tied together by ownership of practically all of the shares of the subsidiaries all down the line. There is nothing new about the device; but the unprecedented elaboration of it permits the power-magnification process to be run into the ground clear down to bedrock. And then on top of this the differentiation of securities comes into play to accentuate the process. If, as in most utility companies, senior reliance is on 
either bonds or preferred shares, the bonds never vote and the preferred shares quite often cannot. And a still further development in the last few years - that of the nonvoting classes of stocks - may carry the business well toward infinity. Take the United Light and Railways Company with three kinds of nonvoting stocks in I923, an authorized total of $\$ 37,500,000$. On top of this is a funded debt of $\$ 26,000,000$. The voting control is vested in $\$ 12,500,000$ of common stock. One of the baldest cases on record of concentration of control of a top holding company is thus described from personal experience by the editor of the Atlantic Monthly:-

In June 1924, the capital stock of the Northern States Power Company of Delaware included $\$ 6,170,000$ in common shares of $\$$ roo par value, and $\$ 36,450,000$ in preferred shares, also of $\$$ roo par value. With the control of this stock went the control of the company. On July I, however, of the same year a new stock was issued of no par value, entitled Class B Stock, to the tune of 500,000 shares at $\$ 10$ a share. This stock carried voting privileges, and its ownership ensured control. On the last day of this same year, I924, it is interesting to observe that of this issue 499,913 shares were in the possession of the parent company of the Northern States Power Company, the Standard Gas and Electric Company. A fairly complete transaction!

But to delve a little further into the Eleusinian mysteries of modern finance. This same parent company, the Standard Gas and Electric Company, realizing that the wide sale of its securities was spreading the control as well as the ownership of its stock, issued I,000,000 shares of voting stock at \$1 per share. These peculiarly priced shares, carrying absolute control of the company, were taken over bodily by the company's promoters, H. M. Byllesby and Company. Thus, after realizing the market value of the shares of the Standard Gas and Electric Company and its subsidiary corporations, the original promoters purchased its continuing control at a nominal price. They have eaten their cake, and they have it still. 
It is probably true in most cases that the controlling common stock of the banking or management firm standing at the head of the utility hierarchies already instanced practically represents no actual investment in first instance. The following table shows the small proportion of capital stock to total system capital obligations for a number of groups:-

Columbia Gas \& Electric

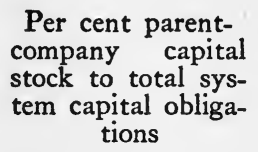

Per cent of gross operating revenue to book value of property tions

American Telephone \&

Telegraph

Detroit Edison

Standard Gas \& Electric Public Service Co., N. J. National Public Service General Gas \& Electric Cities Service Co. American Water Works \& Electric

If one were to cut down some of these percentages still further - National Public Service, for instance - by resort to the nonvoting-stock device, an almost unbelievably exaggerated inverted pyramid of control would be disclosed. On top of all this, you may add, if you please, that this infinitesimal fraction of controlling shares at the top may be trusteed as a still further measure of protection against loss of control. This pyramiding of control is perhaps the most menacing feature of the entire situation, viewed with respect to the observance of fiduciary and public responsibility over a long vista of years ahead. 
A further serious defect of overdeveloped holding company organization is the temptation afforded to prestidigitation, double shuffing, honeyfugling, hornswoggling, and skullduggery. Sound and defensible management shades off almost imperceptibly under stress of self-interest, given such concentration of control as has just been described, into all sorts of nefarious dealings. Practically all of this lies within the domain of financial activity. It takes its strength from domination through common stock control of banking houses which may or may not have a sufficient actual investment to hold them to a steady course. Public utility systems, large and small, are now commonly affiliated with a single banking house. It is rather the thing to do, giving prestige to even the lesser bankers to establish themselves in such positions of responsibility. The open market for competitive financing is, of course, thereby closed, and perhaps in this pioneering stage necessarily so. Even the enjoyment for the nonce of the cash resources of the system might, in a pinch, under nonchalant or irresponsible chaperonage, be right convenient. Such things do happen. Most of this banking service, it goes without saying, is above criticism. Yet a sufficient number of lapses have already occurred to reveal the possibilities of wrongdoing. Probably the most illuminating instance is afforded by the Slaymaker case, in which $\$ 1,136,000$ was recovered by shareholders of the Columbus Railway, Power, and Light Company in 1923 from the banking house which had assumed charge of construction work, internal and external financing, management, and allied services. An indication that this is not an issue local to the United States is found in the recent report of the Committee of the British Board of Trade on Amendment 
of the Companies Acts, in which a glaring defect in the statutes is detected - that there is "nothing to prevent a holding company from using the dividends received from profit-making subsidiaries in order to pay a dividend on its own shares without taking into account loss suffered by other subsidiaries. ... The effect of this may be that the holding company is paying a dividend at a time when the group as a whole is in debit on the year's working."

Baldly, of course, crossed wires within a large corporate system are indefensible; but how subtly sound policy trails off into a dubious one. Shall the loss on the traction or gas end of the business be averaged in with the profitableness of the electric light and power? Where is the line to be drawn between such allied companies, including natural gas, and excursions into the field of oil development? How far are the strong central station urban companies to uphold by main force the thin ends of rural pioneering? How great the temptation is well shown by concrete instances - for the banking house controlling a holding corporation to make use of it as a convenient dumping ground for securities perhaps unprofitably underwritten. Are profits on sales of securities of operating concerns by the holding company a proper addition to income on the consolidated balance sheet? In other words, is the top company to stand on its own feet separately and independently of its component parts? Suppose a principal operating company, A, has four subsidiary holding companies, B, C, D, and E. Company E buys a subsidiary for $\$ 1,000,000$; it passes it on to $\mathrm{D}$ for $\$ 1,250,000$; D passes it on to $\mathrm{C}$ for $\$ 1,500,000$; $\mathrm{C}$ to $\mathrm{B}$ for $\$ 1,750,000$; B finally to A for $\$ 2,000,000$. Nothing has been added to the group in the way of earnings, and 
yet $B, C, D$, and $E$ might each declare a dividend of $\$ 250,000$ profit to $A$. Such things are rarely done, certainly not in such bald fashion as this, but over a very considerable period of time such transactions do crop out despite their indefensibility.

Equally serious, especially in this domain of public utilities, is the disposition of some of these holding companies to adventure far afield in search of profit, even though it carry them well beyond the natural province of utility operations. This is fortunately rare, but it is also sufficiently in evidence to call for reprobation. The Southern Ice and Utilities Company, serving a population of 960,000 , may naturally enough slip over from ice into ice cream and creameries. The transition from artificial to natural gas, and then again from natural gas into petroleum development and refining, is not unnatural. A certain amount of it is perhaps inevitable. But when the Standard Gas and Electric Company owns a majority of the common stock and some of the preferred shares, and guarantees "as to principal, interest, and sinking fund" $\$ 8,300,000$ worth of bonds of the Shaffer Oil Company, "a complete unit in the oil industry, embracing petroleum production, transportation, refining, distribution, and marketing," it becomes a matter of substantial interest, not only to the 110,000 ordinary and customer stockholders, but to a general public scattered over some seventeen states of the Union as well. Yet the Standard Company in its annual report does not give even a résumé of the affairs of this oil concern. Although the statements of all the other subsidiaries are given in full, it merely recites that the oil earnings have increased some 90 per cent during the year. It strikes me as decidedly casual, to say the least. One queries what 
would be the effect of its inclusion in a consolidated balance sheet, if there were one. Then there is Cities Service Company. This premier public utility holding company first dipped into the oil business in 1915. By I920 from this source flowed 8I per cent of its consolidated gross earnings - less than one fifth of them from public utilities proper. Apparently oil saved the day in that year of trial. Thereafter the oil business dried up relatively; then again it took on new life after 1923; the proportion of consolidated gross earnings thereafter rose until in 1925 it amounted to about $3^{8}$ per cent of the total for the system, contributing something like the same proportion, apparently, to net income. In this second instance the whole story is set forth frankly in the published reports, so far as gross earnings are concerned; together with plans for further development of "large acreage in Louisiana, Texas, Oklahoma, and Montana." One stands face to face with a dilemma under such circumstances, which can best be baldly stated in terms of logic. Such a company is either a public utility or it is not. If it is, it has no possible right to be engaging on any such scale in one of the most speculative businesses in the United States. If it is not, it has no right to be posing as a public utility, adding $4 \mathrm{I}, 000$ new stockholders to its list in 1925, most of them customers, to bring the aggregate up to 235,000 , one of the very largest lists for any corporation in the world. As merely a quasi-investment agency it might do one thing; as a public utility, another. In all decency it cannot do both.

And, oh, the annual reports of these full-flowered interstate supercorporations! Any impression that supermen competent to handle them from the standpoint of 
intelligibility have thus far been evolved will vanish on slight acquaintance. Try it for yourself - not for the state-operated and state-regulated companies, of course, but for the top holding ones. Many of them pursue a straight course in this regard. Some, like United Gas and Improvement, and, notably, the Consolidated Gas, Electric Light and Power Company of Baltimore, have recently made encouraging progress. But for the bulk of them, the maze at Hampton Court, Einstein's theory of relativity, current political platforms on prohibition, are not in it with them for convolution. Try - even with those holding companies listed on the New York Stock Exchange - to reconcile their statements for private consumption with those which are rendered to their public shareholders. Even with the best of intentions the current kaleidoscopic transmogrifications are utterly thwarting to any attempt at comparisons from year to year. Attempting to deal with them reminds one of Lincoln's characterization of office-seekers. "Paton, did you ever try to shovel fleas?" Reappraisals at cost of reproduction, perhaps on an ever-new price footing, still more completely knocks the ground from under any such attempt at an historical analysis. Cities Service denies to its 235,000 shareholders in 1925 any information about the earnings of its subsidiaries, confining its consolidated statement of earnings to seven lines of type. Its outline of earnings year by year would be informative, except for the utter absence there and throughout the report of any reference to retirement or renewals. They simply do not occur in the document.

Some corporations blandly allocate to themselves all earnings of their subsidiaries, figuring results in percentage earned on capital stock, quite irrespective of the minor 
detail as to whether these earnings have been distributed as dividends or not. Most of these companies afford a consolidated income account and balance sheet, but Northeastern Power, while its securities have been issued in large volume, gives no earnings whatsoever, even in the prospectus, presumably because there were none. Some companies trifle a bit with the shareholders' patience, as it seems, in respect to the lag between close of the fiscal year and distribution of the statements. And a whole group of companies, in varying proportions combined of investment trusteeship and operating management, - American Super-Power Corporation and Electric Bond and Share, for example, - while vouchsafing a list of their investments, afford no indication whatsoever of the number of shares or of the cost thereof as carried on their books. Inadequacy and "limitless obfuscation" that's what a lot of these perpetrations are. The prospectuses, by means of which an appeal is made to the public for purchase of new issues of securities, are distinctly in need of tonic treatment. This is the situation in 1926, according to the Committee on Public Service Securities of the Investment Bankers Association of America: -

Only comparatively minor defects and omissions have been noted in any of the circulars offering securities of operating companies and it has not been necessary for us to bring any of this class to the attention of the Board. A considerable number of circulars offering the securities of holding companies do not come up to the proper standard. The general deficiency is in failing to give as recommended in the above-mentioned pamphlet a "clear statement of capitalization showing prior securities outstanding, including those of subsidiaries." It has been necessary to report to the Board several of this class which seemed most lacking in this respect. 
The last serious indictment against the overdeveloped holding corporation in the public utility field has to do with rate regulation. Under the terrific involution of accounts it may become practically impossible to allocate costs and to determine earnings as related to the investment. The holding company is exposed to the temptation to exploit its subsidiaries, taking its own profit by undue enhancement of the operating expenses of the local concerns. Alpha Company, the operating concern, apparently runs at a loss, while Omega Company, which holds its stock, pays dividends nevertheless. Such things may be accomplished by overloading management expenses. "Too many crossed wires" was the newspaper headline applied to the Massachusetts Public Utilities decision in 1916 , when something like $\$ 240,000$ out of its total expenditures of $\$ 318,000$ was paid by the North Adams Gas Light Company to the Light, Heat, and Power Corporation of West Virginia for current supplies, construction, and management. How easy for the interstate holding company to dilute earnings in order that they may become digestible in the public view, and how difficult in a massive hierarchy of such holding companies to trace anything like costs in relation to investment back to some solid bench mark. How difficult to pass upon the reasonableness of contracts for use of property or sale of power. This too has recently been brought to the attention of the Massachusetts legislature. Formal proceedings degenerate under such circumstances into a mere muzz of words. 


\section{XI \\ PUBLIC UTILITIES \\ STILL MORE ABOUT THEM}

Public utility finance under these current merger transformations is going through a process of change little comprehended by the general public, to whom appeal must of course be made for the necessary funds attendant upon its growth. The new capital issues by such companies in 1925 alone reached the stupendous total of $\$ 1,500,000,000$, upward of one third of the total new corporate financing of the country. Of bonds alone, $\$ 892,000,000$ at par were placed on the market during the twelvemonth. It is essential that these changes be clearly understood, because a substantial and everincreasing part of this new capital is being drawn from the little people, particularly by the sale of customer securities.

First, one must keep clearly in mind the distinction between the financing of the basic or operating concerns and the issue of securities by the top holding companies. As for the former, the unusual preponderance of funded indebtedness is noteworthy. Among railroads such indebtedness, although it far exceeds that among industrial corporations, used to find its equilibrium at about a fifty-fifty figure. It has since considerably exceeded this proportion. But indebtedness now is distinctly on the wane, proportionately, especially among the strongest companies. For the public utilities the normal minimum 
of funded indebtedness is about 60 per cent of the total capitalization, with the balance more or less evenly divided between preferred and common shares. The public regulatory commissions are in part responsible for this relatively high proportion of senior issues among the operating companies, assuming perhaps that essential industries characterized by a fairly stable rate of return independent of cyclical fluctuations can well support so heavy a burden of fixed charges.

The major reliance of the new interstate holding corporations, on the other hand, is upon the issuance of preferred shares, and it is particularly in reference to these, since they are most widely dispensed in connection with customer ownership campaigns, that the true situation should be made clear. Such preferred shares ought properly to stand first in their rightful claim to whatever income from investments the holding corporations may be entitled. If preceded by bonds of the holding company, they ought to be widely distributed only in cases of exceptional soundness of the subsidiary concerns. And even where there are no bonds issued by the top company, it should be clear that mortgage indebtedness of the subsidiaries is not unduly heavy. Such securities are in considerable measure the result of the discovery a dozen years ago of the device of customer ownership for public utilities. These companies, eager to raise funds up to the full measure of the equity in their properties, have since been enabled to dispose of such shares too often to represent the entire margin between feasible bond issues and the full value of the property. Such financings, through offerings of preferred shares to the general public in small allotments, are made directly, without the intermediation of banking houses. That has the 
advantage, of course, of eliminating commissions; but it is open to the marked disadvantage that the long-time experience and natural conservatism of the banking fraternity is denied to the consumer. Such preferred shares of holding companies are not comparable as to security with similar shares, either of operating companies or of railroads, for that matter. That, of course, is why they yield so much higher rates of return.

A particular menace lies in the appeal, often under guise of a plea for simplification of an involved corporate structure, for the little holder of bonds of a local operating enterprise to give them up in return for shares of the newly created finance corporation. Such exchange of course has to be lubricated by a tempting offer of a larger immediate income from the new securities. First mortgage bondholders of the Richmond, N. Y., Light and Railroad Company in 1926 are invited to increase their revenue from a bond from $\$ 40$ to $\$ 63$ per annum by accepting preferred stock in the Associated Gas and Electric Company. Now as bondholders on their local property they had a first claim upon its revenues. As preferred shareholders of the top holding company, there were in 1925 interest charges upon almost $\$ 50,000,000$ of bonds which took precedence over them as to income. Whether the added income was worth the change of status is a question of moment, to which the uninitiated give but scant attention.

The danger described above is contemplated in the preamble to a resolution of the board of governors of the Investment Bankers Association of America, May I4, 1925, as follows: "It is obvious that, from the standpoint of sound investment, it is inappropriate for many investors to exchange mortgage bonds of operating public 
utility properties for the preferred and other stocks of public utility holding companies." For obviously by such exchange the uninitiated investor may have shifted his position from that of a preferred to that of a junior claimant upon earnings. The financial record of preferred issues of operating companies is on the whole excellent. By and large, noncumulative preferred shares in any enterprise are not inaptly described by a leading lawyer as "waifs of the stock market." Honorable Bainbridge Colby, late Secretary of State of the United States, recently pictures the status of such securities as follows: "There is not in New York city a lender on a second or third mortgage who is not in a better position than the average holder of preferred stock of corporations. It is difficult to define the position of the preferred stockholder. $\mathrm{He}$ is denied participation in the control of the corporation; he is on the poorest terms of them all." Such securities fall between two stools. The man who holds them is neither a partner sharing in the increment of future growth nor a true creditor with a prior lien upon earnings and assets. They are exposed to the danger of vanishing returns soon to be set forth in another connection, as well as to the possibility, unless duly safeguarded, of the intrusion of new securities with prior claims upon earnings to their own. Nevertheless, within reasonable limits they have proven themselves a present help in time of trouble - that is to say, a handy means for satisfying the gluttonous appetite of this lusty, growing industry for capital. The upshot of this warning, then, is not that their use should be prohibited, but that their possible precariousness should be safeguarded by some substantial measure of public supervision. This the separate states are incompetent 
to give. The matter lies entirely beyond the scope of their power.

The new holding corporations, topping off these recent consolidations, depend, of course, for their income upon dividends paid by the operating companies. They have little if any real property which can be mortgaged by bond issues directly. What they do, therefore, besides selling preferred shares of stock, is to mortgage the income from their investments in shares of these subsidiaries, through the sale of collateral trust bonds, secured by deposit with a trustee of these selfsame shares. Obviously the proportion of bonds, if any, must be less than with their subsidiaries. That is the reason why they depend so much more largely upon raising funds by disposal of their preferred shares, or it may be in part of common shares; although these common shares which spell control are customarily quite closely held. Concerning the bonds of these holding companies, then, few people understand that they are not a true bond in the sense of being a mortgage upon property. They are not permissible for investments of savings banks, for example, in a conservative state like Massachusetts, which limits such investments to mortgages upon operating companies with direct liens upon property. Nor is it true - except, as we children used to say, "over the left" - that the bonds of these holding companies constitute the "only funded debt of the company," if perchance there is an odd hundred million or so of bonds of the subsidiary companies which have a prior claim upon the same income. The legend in capital letters on the prospectus of the Northeastern Power Corporation in 1926, "No Funded Debt," fails obviously of a statement of the truth, that every bond outstanding of the subsidiary 
corporations stands ahead of the holding company issues. The prime test, therefore, of financial stability for these holding corporations, particularly for the preferred shares which come after bond issues, is that such mortgages should not be issued to excess. And yet in some instances the proportion of bonded indebtedness rises as high or higher for such holding companies than it customarily does for operating concerns. It should be said that the present tax policy of the Federal Government puts a premium upon such financing by holding companies, as well as all others, inasmuch as the deduction of interest upon such borrowings before computation of the tax upon net earnings is permissible.

Examples of such heavy borrowings are abundant. Thus for the National Public Service Corporation, fixed charges on account of funded debt ranged in 1925 about 70 per cent of earnings, and seem still to be on the increase disproportionately. Expansion seems in this instance to be going on also through rapid increase of the borrowings of subsidiaries, so that consolidated interest charges are growing more rapidly than earnings. For Middle West Utilities, also, fixed charges consume, so far as one can figure it, about two thirds of the earnings. Yet it is difficult in any such instances to establish the unwisdom of the capital structure on the mere basis of the annual reports. It may well be that substantial provision for future development has been made, so that the overload due to borrowings is but a temporary defect attendant upon growth. Comparisons, as has already appeared, are rendered extremely difficult because of the great diversity of practice in keeping accounts. Perhaps the largest single public utility issue in 1926, that of $\$ 65,000,000$ in bonds of the Associated 


\section{I6 MAIN STREET AND WALL STREET}

Electric Company, put forth for the laudable purpose of simplification of the capital structure of the system, represents investments of this class. Such securities are perfectly proper as a form of "conservative speculation, that is to say, when restrained within suitable limits in proportion to earning power and assets." But in any event they are subject to the danger of vanishing returns soon to be described.

The importance of a clear understanding of the nature of some of these investments is recognized by conservative bankers. Repeated warnings for the last three years have been issued by the committees on public service of the Investment Bankers Association of America. Here is the way the matter was put officially at the St. Petersburg, Florida, convention in 1925. "This is a perfectly legitimate investment for the investor who knows what he is getting. The great difficulty is in getting up a description (in circulars) of securities of this sort which will let the investor know how far away he is from the operating properties and how much in the way of subsidiary-company securities there is ahead of him. A great many investors will buy holding company securities who would not buy the common stocks that they represent; and in many cases they are attracted to the security because it is set up as a bond. . . . It is customary in this country to permit a very large proportion of senior financing, so that the ownership in the hands of the actual proprietors of the property is apt to be a rather small proportion of the total. Where this small proportion of ownership is used as a base of further loans through holding companies, the investor who takes such securities may be getting dangerously far away from the actual property. There is no objection to his 
investing money in these ultimate equities if he understands fully what he is getting, and in many cases an investment of increasing value may be made, as has been well illustrated in the recent developments in public utilities securities; but before investing his money this way, he should be fully informed as to exactly what he is getting." 1

These public utility holding companies thus financed are, as we have already seen, highly provocative of pyramiding of control. In much the same fashion they lend themselves also to magnification of financial returns. Pyramiding in this second sense consists of "making a little capital go a long way." It is otherwise defined as "the custom of trading on a thin equity, control resting in the hands of the common stockholders, while the funds are supplied by the sale of preferred stocks and bonds." By this simple expedient, then, the attenuation of the equity in the property brings about an abnormally accentuated rate of return upon a relatively small part of the total investment. This contingency of magnified earning power operates something like the nozzle on a hose pipe - in speeding up the flow, so to speak. But the financial danger in such a set-up, customarily created on the crest of a wave of prosperity, arises from the littleappreciated but simple mathematical proposition that declines are accentuated as truly as are increases in revenue. In other words, a minor drop in the income of the operating concern is at once translated into a major one for the holding company.

By way of concrete illustration, assume that a holding corporation owns all the stock of a subsidiary operating

1 Cf. also Report of the Public Securities Committee of the Association for I916 concerning criteria of sound investment value. 
company, and that the subsidiary has no preferential securities, bonds or stocks, with a claim upon earnings prior to the dividends of the top corporation. A fluctuation of Io per cent up or down in the earnings of the subsidiary will, in precisely the same degree, affect the income of the holding corporation which is derived from these earnings. But now assume that the subsidiary has already mortgaged 50 per cent of its income, for payment either of interest on bonds or of cumulative dividends upon preferred shares. Then, with a ten-per-cent fluctuation in earnings of the operating company, the entire change is focused upon only 50 per cent of the capitalization - that is to say, the junior stocks of the subsidiary. In other words, a shrinkage of one tenth in the income of the subsidiary all falls upon its junior dividends, which derive from only one half of its capitalization, reducing them by one fifth instead of one tenth. And just in proportion as the fixed charges of the subsidiary increase, so in geometric ratio, with a drop in income, will the revenue available for dividends to the top company fall. If the prior claim on the subsidiary for bond interest or preferred dividends consumes 80 per cent of its total earnings, a drop of ro per cent in net will cut the dividends payable to the holding corporation in halves; if the prior claims are 90 per cent, this minor change in operating income will wipe out the income of the top company entirely. And so it goes. In other words, a small normal variation in the rate of return of the operating subsidiary may effect a very large and abnormal change in the rate of return upon the junior securities of the holding company. And each corporation piled upon another in series, provided each of them has a certain amount of fixed charges, magnifies its sensitiveness still further. The 
explanation of resort to this dangerous device is, of course, that fluctuations upward are magnified for the holding corporation in time of prosperity, just as they may move conversely in time of depression. This characteristic of holding company finance, thus somewhat tediously stated, may readily enough become a root of much evil. It is said from the outset to have been a veritable bogeyman in the estimation of the farsighted founder of the General Electric Company, Mr. Charles A. Coffin.

The application of this principle of sensitive or of vanishing returns, to coin a phrase, for holding corporations is intended to be demonstrated by the following table.

FISCAL YEAR 1925

Per cent reduction Per cent reduction Per cent of in operating income necessary to wipe depreciation (after taxes and depreciation, but before interest) necessary to wipe out all earnings of parent company, applicable to dividends

Columbia Gas \& Electric $\quad 79$ out all earnings of for year to parent company plant value, applicable to end of year dividends and interest

88

I.I3

American Telephone \&

Telegraph

Detroit Edison

Standard Gas \& Electric $\quad 56$

Public Service, N. J.

National Public Service

(I926 - 26.8 to June 30)

General Gas \& Electric

Cities Service Co.

American Water Works \&

Electric

76

64

56
36

30.5

26.4

I9

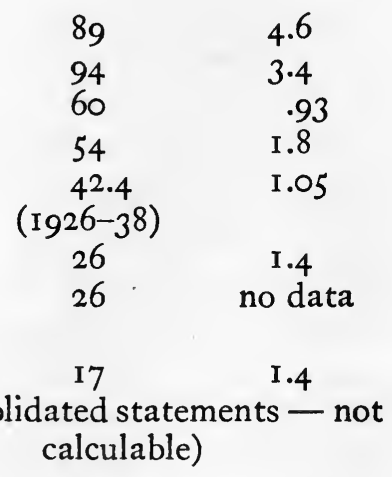

I 2 Middlewest Utilities Co. $\quad$ (no consolidated statements - not

It purports to show the relative stability of the financial set-up of a number of different holding companies in face 
of possibly fluctuating conditions of business from year to year. Detroit Edison, by the way, does not properly now belong in this group. It has transformed itself into a compact, highly efficient, and conservatively managed operating company. But comparison of its data is valuable from other points of view. It will be noted that these tables are only rough approximations. No attempt, for example, has been made to figure the reduction of operating expenses which attends a lessened volume of business.

Judged by this exhibit alone, these companies range in financial stability from top to bottom. Thus, for example, one of them, Columbia Gas and Electric, precedes even the almost impregnable American Telephone and Telegraph Company, in that it would require a reduction in operating income of 79 per cent to wipe out earnings applicable to dividends for the parent company, and actually 88 per cent reduction in earnings to cut the ground from under interest on its funded indebtedness. At the opposite extreme stands the American Water Works and Electric Company, in which so slight a reduction in operating income as 12 per cent makes dividends of the parent company impossible, I7 per cent cutting off even its interest on holding company bonds. The knife, of course, cuts both ways; and in the present time of prosperity one may figure earnings for the last fiscal year in excess of 20 per cent on par of the common shares of the top company. Yet one cannot resist a doubt whether such a public utility engaged in indispensable service for $3,500,000$ people, in fourteen states, is on entirely safe ground with so narrow a financial margin of safety. It should be distinctly noted, however, that of course this particular test is but part of the story. One must dig much deeper in order to judge whether 
even such slight fluctuations as these in each particular case are apt to occur. A company like General Gas and Electric, or Public Service of New Jersey, operating in a dense industrial district, with many first-class stations, may more than counterbalance any defect in its set-up by the inherent strength of the several units of which it is constituted. On the other hand, National Public Service Company, by reason of its high proportion of fixed charges (about 70 per cent), made up as it is of less dense traffic, may appear unduly strong in such an array of its rivals. Or, again, one has to consider the proportion of what may be called outside or unrelated income. Both Standard Gas and Electric and Cities Service, as will be shown directly, are deeply involved in oil development - something which comports ill, when pushed to such an extreme, with the operation of a public utility. Thus it appears that this showing is by no means conclusive. But there can be little doubt that it is indicative of a dangerous tendency in certain quarters, which should be promptly taken in hand.

Answering this criticism, it is averred that these electrical utilities are inherently immune from the ill of fluctuating earnings which harasses other lines of business; and consequently that they may safely trade upon a much thinner equity. This is probably in part true. Yet their apparent stability is somewhat beclouded by the practice of loading retirement and renewal upon the good years, lessening the burden in the lean ones, thereby smoothing out the curve from year to year. It must be remembered, moreover, that since becoming really fullblown they have not been called upon to weather a really protracted period of frost. Sharp stabs we have had, but no long lingering chills since 1893 . The drouth west of 
the Rockies in 1924, as affecting Pacific Gas and Electric, affords a good local example. Perhaps they may never recur. Who knows? Moreover, one is tempted perhaps to take a chance, so deep-seated has become what Lyon aptly calls "the growing habit." The worst that most of them have had to endure has been a lessened rate of growth, but always there is growth. Yet an examination of the ratio of net earnings before interest to the average plant, for two typical large utilities, each covering a wide territory (nine states altogether), indicates that earnings for one of them dropped in 1920 by about 50 per cent, as compared with 1918, and for the other dropped in 1921 by 33 per cent, as compared with I9I9, only to rebound in 1922 by more than 40 per cent. The company which, disregarding compensation by deferred depreciation and facing the issue manfully, did not experience a real jolt in 1920 is the exception, not the rule. It is important to notice also that these utilities are handicapped either on a rising or a falling industrial cycle through their inability to shade prices to meet competition or to advance prices as an offset for heavy operating costs. They cannot change price policies, forestalling the future, without official administrative approval. The Steel Corporation, in its trade policy adhering to the principle of fixed prices, is yet free in a pinch to deal with extreme situations. This the public utilities may not do; and they must face the future, with whatever chance or change may come, without recourse to this advantage.

A widespread criticism of the unwarranted complexity of the financial set-up of these top companies is not without foundation. An exaggerated instance is afforded by the Associated Gas and Electric Company. This concern is not unimportant, serving, as it does, a population 
of $1,750,000$ in eight states, the Philippine Islands, and so forth. Its capital structure, however, was recently characterized by Barron's Weekly, assuredly a competent critic, as "a financial nightmare." "If bond salesmen, like lawyers, had to pass a test of their competence to practise the profession, the problem of the complexities of the capitalization of this company would be too much for all but the most expert. As of December 31, 1925, there were four classes of preferred stock, Class ' $A$ ' stock, Class ' $\mathrm{B}$ ' stock, and common stock outstanding. In addition there were outstanding interest-bearing option warrants with the choice of conversion into several other securities. Several million dollars of convertible debenture certificates were also outstanding, which carried the unusual feature of conversion at the option of the company. Besides this miscellany of securities, there were of course large amounts of bonds, preferred stocks, and minorities common stocks of subsidiaries in the hands of the public." It deserves to be added that plans are under way to straighten out this tangle. It would not be difficult, however, to match it with a number of others. Cities Service Company, with its B and double B preference shares, is another case in point. Such intricacy is always apt in any corporation to result from the gradual accumulation of financial operations through many years. Railroads, for instance, periodically go through a financial housecleaning in order to clear up such an accumulation of odds and ends. But the unusual circumstance is that among the public utilities some of the most complicated structures have been thus deliberately set up from the start. The best among them, however, are evidently working with more or less success toward plainer living and higher thinking in this regard. 
No comment upon public utility finance could omit consideration of the age-old charge of stock-watering that is to say, of the overissue of securities in proportion to the actual investment. Public interest in this matter usually arises from the misconception that somehow overcapitalization creates in and of itself a higher scale of charges for service. This notion is now completely exploded. It is peculiarly vulnerable as respects these top holding companies, which of course have nothing whatsoever to do with the determination of rates. They simply live off the earnings of subsidiary companies, each of which in turn has its schedule prescribed nowadays under more or less strict state regulation. Under these circumstances there is no possibility of any interrelation between overcapitalization of the holding concern and the rate level for the subsidiary operating company. The industry itself never wearies of demonstrating this point. Yet the experience of three generations demonstrates that the public has a rightful interest in this matter, but that the foundation of that interest is in the fact that an overissue of securities in proportion to the investment tends to dilute credit to the end that there is an impairment in quality of the service which it is possible to render. In accordance with this principle, these top holding companies are tied in, then, with the public interest by virtue of the fact that they serve primarily as guide and financial next friend for their subsidiary hosts. If the financial company is weak, the operating concern is bereft of the advantage of this comfort and support. It is in this sense, then, that an examination of this charge is warranted upon the broadest possible grounds.

The best way to demonstrate the customary technique of the issue of junior securities for no valid consideration 
is by a concrete case. At Conowingo, Maryland, on the Susquehanna River, a first-class hydroelectric enterprise was projected recently. Lying in both Maryland and Pennsylvania, the matter came under the jurisdiction of the Federal Power Commission at Washington; and inasmuch as no administrative control over finance was exercised by Pennsylvania, this federal administrative body assumed fiscal jurisdiction. The enterprise was to cost $\$ 52,220,000$.

The financial set-up first proposed included the sale of bonds to yield $\$ 35,4$ I0,000 and of preferred stocks to yield $\$ 16,810,000$, thus aggregating the entire estimated first cost of the enterprise, $\$ 52,220,000$. With the project thus wholly paid for, in addition thereto a large number of no-par common shares were to be issued: Class A common shares, which were to "sweeten" the distribution of the first preferred stock, and Class B common shares, carrying sole voting power, which would involve no investment whatsoever. All these common shares, therefore, represented that which in the popular view is held to be an overissue of securities. No valid consideration whatsoever was to be given for them. This set-up - entirely in good form, judged by customary standards - was set aside by the Commission, however, and an order strictly conformable to the most advanced criteria of public regulation took its place. In this order the bond issue remained as before, to pay for the bulk of the installation. But the amount of the preferred shares was cut down, and it was then required that a par value of $\$ 25$ per share should be paid in for the common issues to make up the balance of the total cost. The net result was, of course, the same; total receipts from sale of bonds, preferred shares, and common stock all together were to 
produce the estimated sum of the investment. Should it exceed this figure, additional common shares might be issued at a fixed par price, producing dollar for dollar what they purported to be worth.

Instances might readily be multiplied of this customary procedure of full capitalization of goodwill and earning power where no public supervision obtains. In the recent Chicago, Milwaukee and St. Paul reorganization hearings, evidence was produced of the purchase of two power syndicates for $\$ 970,000$, immediately transformed into the Montana Power Company at $\$ 5,000,000$, and earning in $19255 \mathrm{~T} / 2$ per cent upon that basis. More recent still is the project of the Northeastern Power Company, said to be the largest hydroelectric enterprise east of Niagara, which, however, rather sidestepped this particular question, by an issue of three classes of no-par stock from top to bottom, coupled even with the minor omission in the prospectus of any statement of income whatsoever - possibly because at the time of flotation the project seemed to be enjoying none. Under such circumstances, both earnings and stock bases being equally ethereal, the charge of overcapitalization can scarcely be substantiated. One is left, therefore, at liberty to give free play to the imagination in deciding what this relationship of assets to capitalization actually is.

A prime cause of excessive issue of securities in relation to value at the present time is the frantic bidding for independent properties either for competitive and strategic purposes or for the immediate profit to be made by turning them over to some incipient combination. Just to be specific, evidence of such exorbitant prices paid has come to me personally concerning such widely separated 
places as Pensacola, Florida; Columbia, South Carolina; Derby, Connecticut; Keene, New Hampshire; Vermont; Minnesota; Michigan, and all over. Shares which little more than a year ago sold below par have been picked up for four times that figure. A well-known company with a par capitalization of $\$ 1,600,000$ refused flatly an offer of $\$ 5,000,000$ for the property. The recent Pennsylvania Giant Power Board reports a rise of 300 per cent in common stocks of electric holding companies in the five years to 1925. Promoters have not hesitated to overpass the normal limit of a price equal to ten times the net earnings, in their zeal for a quick turnover, not troubling to examine too closely into the situation. The promotion of the Northeastern Power Company, above mentioned, is also apparently an instance of such excessive prices paid. Several, in fact, of the good-sized holding companies seem to have been constructed upon such a flimsy footing from the outset. Old-timers in the industry, with a background of long experience, do not hesitate to condemn such practice privately, holding as they do that such financial excess is bound to bring about a reaction.

The matter is expertly described in the words of President Samuel Ferguson of the Association of Edison Illuminating Companies in I926:-

In defense of the practice of purchasing operating companies at from several times the face value of their existing capitalization, and consolidating them into a new company on the basis of the purchase price, it has been urged that the customer cannot be affected by the number of pieces of paper issued by the new company, since he is protected by the limitation of earnings to a fair return on the value of the property. Theoretically, this is so, but practically he does not have a full protection from injury unless injury is by definition limited to the rates charged. The injury from inadequate service and the 
inability of a company to care for the growth of a community is quite as real, and often much more serious, and yet this must be the result in the case of an overcapitalized company which, through its limitation to a reasonable return on the property value, has earnings insufficient to maintain its credit. The public has had enough of receiverships in the recent trolley situation, and would yield to the demand of a company to be allowed to earn more than a reasonable return in order to maintain its credits as being the lesser of two evils. Consequently, we must shape our course in such matters with a clear knowledge that the public has an interest in the extent of the capitalization of our companies and that if our liberty of action in this respect is abused, as it is to-day being abused in some cases, there will be an eventful day of reckoning, and when that day comes it may not be possible to separate the sheep from the goats.

When a company is sold for many millions of dollars more than has, apparently, been paid into the treasury for the purpose of providing facilities for service, we must realize that the public is bound to sit up and take notice. What the public sees is that only a comparatively small fraction of the purchase price is represented by what the company receives for the stock at the time of issue and that the new owners must of necessity earn a return on the whole of the price paid; therefore, regardless of the soundness of the reasons which may justify the transaction, it is only natural to expect that the public will insist on being convinced that its interests are fully safeguarded, and apparently it does not to-day feel at all sure that such is the case. It is, indeed, a very curious situation which exists at the present time in that the stocks of our operating companies are of so great real value to the holders, due to the future equities contained in the same, that they should not be parted with except for a price so high as to make the recapitalization of that price a potential cause for future antagonism.

This is a real problem; and one which cannot be avoided by simply refusing to accord it recognition.

The almost irresistible impulse to pad income accounts 
is one of the evils of permitting capitalization of these interstate public enterprises to go on without let or hindrance. The purpose, of course, is to lay a foundation for further public sale of securities. Customarily, since the common shares represent no value, it makes little difference how many there are. Every effort, therefore, is directed toward making a strong showing of earnings, in order to warrant as large an issue as possible of new preferred stocks or bonds. Promotions and new issues of securities, of course, always take place on the crest of a wave of prosperity, whenever feasible under stimulus of speculative furor. In consequence there is too often an overweening temptation to bank upon future prospects through inadequate provision for depreciation, retirement, and renewals; or to puff up the income account by crediting profits on intercompany transactions within the system; or to reappraise assets on a rising scale of general prices - all such procedure to lead up to a full capitalization of the earning power thus sometimes speciously demonstrated. It is this combination of overissue of securities regardless of plant value, supported primarily by the utmost demonstrable earning power, coupled with the high proportion of this new capitalization consisting of bonds, which tends sometimes to produce a condition of extreme topheaviness or of instability in the case of the weaker concerns. Rarely does it happen that a company like Columbia Gas and Electric, as in 1924, not only currently reduces the par value of its capital stock outstanding, but reënforces itself at the same time by peculiarly heavy reserves for retirement and renewals; or that one like the General Gas and Electric Company pays off all its funded indebtedness, clears up its current obligations, and accumulates a large reserve of unpledged 


\section{$33^{\circ}$ \\ MAIN STREET AND WALL STREET}

securities in the treasury. Rather is the disposition all the other way, particularly among the companies which make it a practice to pay all or a part of their dividends in stock instead of in money.

An urgent disposition toward overstatement of earnings may even bring about the payment of dividends not warranted by the actual income. A prime service of most of the management corporations within the great systems is to market securities for their operating concerns; and assuredly, by reason of both volume and prestige, they can do this to better advantage than can the small or isolated companies acting alone. But a nice question is raised whether profits which flow from such financing by the management companies - either controlled or, it may be, owned by the top holding company, but in either event component parts of one system - are really distributable profits of the system or not. Many of them would disappear from a consolidated system income statement, wherein pluses and minuses cancel one another. Perhaps that is one reason why certain of these large companies betray such a marked indisposition to the publication of consolidated statements at all. Middle West Utilities Company (I44,000 shareholders) for I925 reports net income for the year of $\$ 5,842,000$. Of this sum, $\$ 3,265,000$ is " net profit from sale of securities to subsidiary companies and others." Without this income, instead of being able to pay the aggregate dividends of $\$ 4,591,000$, on three classes of stock, the company would by no means have been able to do so. The same year witnessed an increase of the authorized capital stock from 900,000 shares to $1,750,000$. Of this doubled capitalization, a considerable number of shares became at once available for marketing. Furthermore, in this, as 
in many other investment corporations, as such concerns practically are, there is a lively rearrangement of subsidiaries going on; and there are construction enterprises being planned, financed, and administered. All the profits from such phases of management are far from being regularly recurrent. Many of them are incidental to rapid expansion. The profits from some of these operations are not properly distributable in dividends - such for instance as virtually amount to marking up the valuation of securities of subsidiaries, held in the treasury. Most regulatory commissions permit no such reappraisal of the assets of operating companies. These great investment concerns, being free from such supervision, may do so at will. They are doing so all along the line, every day, during this phenomenal era of prosperity. But such revaluations are paper profits, not real ones at all. What needs to be done is sharply to distinguish in the accounts, and in published statements - a thing which is seldom done - between the regular operating revenues and those perquisites of management which ought not to be distributed, but which should be salted down against an evil day when something may happen to the other side of the ledger.

Another apposite instance of debatable bookkeeping! The income account of Standard Gas and Electric Company for 1925 - no consolidated statement is available, eliminating duplications - again includes the item of "net profit on securities sold, \$1,266,000." This is practically equal to the amount carried to surplus for the year, after dividends on the common capital stock. Query once more: Would those dividends have been justified without resort to this subterfuge? For it can hardly be denominated anything else, even if it follows a rather 
well-known line of procedure. Baron Münchhausen once performed a bootstrap feat of somewhat the same cast. In his case it seems to have worked successfully. But, as I remember it, he tried it only once.

A rather unconscionable bit of window-dressing, which still further illustrates our point, by this Standard Gas and Electric Company, while apparently for the purpose of creating a still more favorable impression concerning the value of its common stock, had to do with its outside oil properties. This company is unique in adhering to the businesslike practice of reporting earnings only upon the basis of dividends actually received - a practice unfortunately not too common among some of its compeers. For 1925 this income was publicly reported to amount to 4.23 per cent upon the common stock. Then the annual report goes on: "For comparison with similar public utility companies reporting consolidated earnings, which would include the collectible income, as recited above, and the Company's interest in the undistributed surplus earnings (after deduction for depreciation and depletion) for the year 1925 of the operated public utility companies and Shaffer Oil and Refining Company, there was earned $\$ 6$ a share on the 765,635 shares of common stock outstanding on December 3I, 1925." Yet examination of the annual statement of the oil company - not published along with the annual accounts of the other subsidiaries in Standard's report - shows that no dividends have ever been paid on its common stock; that there are arrears of cumulative dividends on the preferred stock amounting to $191 / 4$ per cent; and that there are no discernible reserves for depreciation or depletion. Does it not even go a bit beyond mere window-dressing for the holding company to make use of these net earnings of the oil company 
under such circumstances to help to create the impression of an earning power for its own common stock almost 50 per cent greater than it actually was? It had II0,000 shareholders at the time!

Whether or not there is to be a progressive overcapitalization of this great business depends in part upon the adequacy of its policy as a whole respecting depreciation and renewal. In paying the present rates of dividend, is it keeping the properties whole? Or is it in part "living off its own hump"? Acute controversy prevails throughout the industry concerning this matter. The dean of the business, veteran president of its strongest company financially, Detroit Edison, is in command of a valiant corporal's guard in this matter. He holds that in point of fact the whole policy of the industry is at fault. His view is that there is a definite life for each item of property in service; and that there should be set aside as a reserve, charged currently against income although not entitled to returns upon it, an amount sufficient at the expiration of that ascertainable life to re-create the property without the issuance of any new securities whatsoever. In opposition to this view, following a far pleasanter path so far as immediate showing of income is concerned, is the theory that for the most part, if plants by liberal maintenance expenditures be kept in prime condition for service, age is of no moment in a property sense, so long as an undiminished ability to serve persists. This policy is naively set forth in the prospectus in 1925 for the great offer of $\$ 65,000,000$ of bonds by the Associated Electric Company, a holding corporation. There is an engagement to set aside certain percentages of gross earnings for "maintenance and depletion" apparently no distinction being drawn between the two. 
These percentages, the circular continues, "will adequately provide for the maintenance of these properties at their present high standard of operating efficiency." And there the matter stops. No suggestion of having to meet the contingency of complete obsolescence of the entire investment seems to be regarded as necessary. Pursuant to such a policy, of course, no considerable reserves are set up, thus relieving current income from substantial deductions for this purpose. The practical difference between the two policies is demonstrated by the second column of figures on page 319. Detroit Edison, true to the sound conviction of Alexander Dow, its president, is the only electric utility in the lot which measures up handsomely alongside the American Telephone Company in respect of the proportion of income set aside annually to meet such possible obsolescence. The difference for all the others is symptomatic of conditions far and near throughout the industry.

The unanswerable refutation, of course, of the present line of reasoning and of conduct is that the mere advance in technique, particularly in the electrical industry, will certainly bring it about sometime that these old plants must be junked, and that entirely new ones must be created to take their place. Truly conservative managers would by this time have created funds available to take care of this matter without the necessity of new capital issues. Fair-weather artists - in pursuance of the prevailing fashion - will trust to luck to be able to re-create the plant and equipment through a forthputting of new stocks and bonds, again trusting to luck that the greater efficiency of the new plant will take care of interest and dividends on both the old capitalization and the new one combined. 
This whole debate, which is of far-reaching public importance, at bottom turns upon which generation, past, present, or future, is to bear the brunt of this consumption of a capital fund. The easy-going policy which provides that the retirement of old plants shall be paid for by the people to be served by the new ones has been aptly transliterated thus by the president of the Detroit Edison Company:-

They are to pay for the upkeep of the living critter which is serving them and also (for some time at least) for the dead horse. . . . Also I am afraid that there will be a succession of dead horses to pay for, and that some new horses may not go any easier on the feed box than did the old ones. . . . That sort of thing sounds too much like the song that these modern youngsters sing to us old folks to explain their purchase of a new automobile before they have paid the last installments on the old one. The new machine is going to run so much cheaper as to allow them to pay the deficit out of the savings in gasoline and rubber. They sing that song to me, those children, and I smile at them, and remember that I was young myself before the days of automobiles. But I don't encourage them. Sometimes they do get away with it. Mostly they don't.

When I find myself managing other people's large investments, I prefer not to take the chance of being able to earn the price of a dead horse out of future economies.

Were the wholesome reasoning, thus picturesquely stated, to be applied to the overwhelming majority of the public utilities of the United States, except the American Telephone Company, it would make a profound difference. As a concrete illustration, one notes the peremptory call-down to the Boston Edison Company in 1922 by the Public Utility Commission as to the inadequacy of its depreciation reserves, on the ground that this policy resulted in an overly high investment as compared with output. This followed from the fact that such retirement 


\section{MAIN STREET AND WALL STREET}

and renewal reserves, if created, would not of course lie idle, but would ordinarily be invested in the plant. Without them the company is bound to be continually in the market borrowing money or issuing stock to obtain capital which otherwise should have been saved out of current income. And that fact, of course, uncovers the nigger in the woodpile, the real reason for the indisposition of the industry as a whole to pursue a more conservative path.

Much of the future of regulation for these utilities whether of rates or of finance revolves about the question of valuation. The contemporary practice, particularly with regard to prospectuses, stock and bond offerings, and the like, is to offer nothing more tangible as a rate base than an appraisal made both under the direction and at the expense of the management itself. Public valuations there are of course for some of the state companies. But some entire states, Maine, for instance, have never made such an inventory, even for operating properties. For these superstate combinations, no authority exists for this purpose. Furthermore, the continued issue of securities is too often being supported by repeated reappraisals based on new costs of reproduction. On a rising scale of prices or a high plateau of prosperity this is all to the good for the management. General Gas and Electric recently added $\$ 8,600,000$ to its property value within six months by such a reappraisal. Without doubt it reflects an additional revenue power. It is not exceptional so to do. But is it wise, even if it be permissible under the device of no-par stock? It could not be done with a definite bench mark as to par value. The most important financing of 1925 , an issue of $\$ 65$,$\infty 00,000$ of bonds by the Associated Electric Company, 
is buttressed by reference to such reproduction cost "very largely in excess of the aggregate of these bonds." The Committee on Bond Circulars of the Investment Bankers Association of America in 1926 makes reference to this "most serious question." This brings us face to face with the fundamental problem underlying all effective regulation, as to the relative merits of cost of reproduction or original investment. The industry is almost unanimous in taking advantage of the present trend of court decisions which confers upon it the full measure of advantage accompanying a rising scale of prices. But a corporal's guard of long heads within the industry frankly recognizes the danger incident to the retention of this principle, when the general price level begins to slip once more, as of course it is bound to do in course of time. They recognize also how this reasoning works in a vicious circle, precisely similar to the way in which in the field of labor the cost of living goes up, becomes a warrant for increased wages, in turn increases still further the cost of living, and thus calls for yet another jacking-up of wages. There is no end to such a process. Problems of such moment, however, lead too far afield for a brief review of this sort.

As respects the future of administrative control over these electrical utilities it is instructive to note the course of events in the field of railroad legislation. For there is not the slightest reason to expect that developments in this new field shall follow any other line. State regulation was at first confined to the determination of rates for service. It then developed that the character of service was dependent fundamentally upon financial status. It was essential to the giving of reasonable rates that the fiscal practice of the corporation should be sound. 
Then came the interweaving of federal and state activity, arising from the reaction of the policy of one state upon another. Widely varying standards in charter provisions, legal powers, and liabilities prevailed. Still pressing for solution of their local problems, each state pursued its own way; until at last, goaded to desperation by the harassment of these conflicting state statutes and policies, the great railroads sought asylum at the hands of the Federal Government. Thus they yielded at last, quite voluntarily, to an insistent demand that regulative power should be applied upon a scale commensurate with the scope of the companies subject to such jurisdiction. And all in and through this, on the part of the people there was the insistence that only through federal control could the whole business of administrative regulation be lifted bodily out from a morass on the one hand of political influence in state affairs wielded by the corporations, and on the other of political blackmail or extortion arising out of the well-known pettiness or corruption attendant upon the government of some of these states.

In the present stage of state regulation it appears that for the most part the operating electric companies, working strictly within state lines, are almost universally subject to administrative regulation as to rates for service rendered. Both as to standards and effectiveness there is the greatest variety of conditions; but, in the main, remedial agencies for dealing with abuse as to charges have been set up. In the domain of financial regulation, however, the field is only half covered as yet. A recent review indicates that only twenty-five of the then existing forty-seven utility commissions were endowed with jurisdiction over matters of finance. For 
the most part the Southern states and the intermountain commonwealths have taken no steps in this direction. And even in highly developed territory, like Connecticut, Pennsylvania, and Iowa, there is no measure of fiscal control whatsoever. Furthermore - and Connecticut affords an illuminating example - all attempts at extension of administrative control financially are bitterly resisted. An active campaign resulting in a significant public report of 1909, urging that power to supervise the capitalization of public utilities should be vested in the existing state commission, has thus far come to naught; and a scandalous alliance between the political machine of the dominant party and utility promoters has already resulted in the enactment of special legislation, which ought never to have come to pass. Fast ripening situations of this sort here and there are serving to call attention to the need of action all along the line. The comforting assurance, then, that there is now adequate state supervision is quite contrary to fact.

A further argument in favor of federal control is that it would tend to check some of the abnormalities which have crept into the charter provisions of the great interstate corporations. The extraordinary immunities from liability for personal profit of promoters, directors, or officers of these public utility companies under the certificates of incorporation of the chartermongering states have already been exemplified in connection with this general topic in an earlier chapter. And in connection therewith the entirely novel concentration of power in the hands of the management of these companies through license to dispose of assets, to issue new securities, placing them if need be in priority over existing issues, to mortgage or otherwise to make disposition of the property of 
the corporation, is also set forth at length. It is these provisions, taken in connection with the abrogation of voting rights for shareholders, which constitute so great a menace to the public interest. It would seem as if by reason of this legal onslaught upon all the traditional safeguards for shareholders' interest that the doors had been thrown wide open to corporate excesses of the worst kind. It is inconceivable that the federal power shall refrain from exercising some wholesome restraint, when it is so apparent that prostitution of state agencies has permitted things of this sort to be done.

Less bald but no less subversive of sound government are the insidious ways in which corporate influence may be brought to bear upon local politics and upon state administrative agencies. For while the petitioners before the state utility commissions may indeed be the local operating companies, the fact that they are represented by counsel provided from the staffs of the great interstate management companies, together with the resort to all of the power and influence of these major units, has created an anomalous disparity between the governor and the governed. In other words, many aspects of this business have developed in size entirely beyond the regulative power of the states. As well set a lapdog to hold a grizzly bear in restraint as to expect that the puny efforts of a single commonwealth shall not be outmatched by the power and prestige of a combination extending over twenty or more states. The contest in 1922 in California over the subjection of water-power companies to administrative control, with the attendant disbursement of large sums of money by the principal companies affected, should serve as a warning against this ever-present danger. It is a struggle also in which the corporate 
influence tends to be cumulative, as respects personnel. The ablest men, looking to a professional career, with its attendant ample emoluments, are continually drawn off from the state administrative boards, to be enrolled among the professional counsel of the public utility companies. State officials, if elected, being at best upon an uncertain tenure of office, could not but be aware that the door of advancement beyond the modest condition fixed by government employment is open only through subsequent employment of this sort. They are thus necessarily exposed to heavy temptation to be complaisant, if not subservient, not stoutly assertive of the interests of the general public. Different by no means from the conditions twenty years ago in railroading! No reason in the least to expect that the people will be satisfied in the end with any other outcome than the creation of power and prestige at the seat of the central government, commensurate with the forces which, as the fruit of the country's long experience with them, have themselves demonstrated that they must be brought under control.

The proposal is persistently brought forward that submission to concurrent state jurisdiction where these companies transcend the limits of single commonwealths be accepted in place of the assumption of control by the United States Government. The offer at the New England Conference in 1926 at Hartford, Connecticut, of the leading public utility companies voluntarily to accept this form of interstate regulation is of this stripe. The utter futility of it in the long run is obvious. The maze of complications which goes with the long-distance development of electrical interconnection is bound to bring involvement, appalling to contemplate, not between two or three companies only, but between two or three times 
as many. Furthermore - and this is the upshot of the whole business - the prediction may be confidently ventured that, as in the case of the railroads, persistence along the line of provincial regulation will result finally in forcing the great interstate concerns themselves voluntarily to seek asylum at Washington. The situation in Maine will repay examination in this regard. This commonwealth, desirous naturally enough of intensive industrial development, in 1909 enacted a law prohibiting the exportation of hydroelectric power. The purpose of course was to keep the factories at or near the dam sites in domestic territory. An issue of no small moment is comprehended. The water-power companies of this state from 1909 to 1926 have increased in book value of their properties from two or three million dollars to upwards of eighty million dollars. The control, furthermore, of these companies has passed far outside the state, practically to New York and Chicago. The situation is complicated by a provincial ordinance which has recently been interpreted to confer power as to flowage upon the owners of all power dam sites. This practically operates to put an end to the sovereign right of eminent domain which should belong to the commonwealth. What is to be done about it? If the state be overaggressive, in the attempt to subject the finances of these interstate companies to state supervision, there is the danger that the companies will fly the state coop altogether, taking refuge in the federal yard beyond - in other words, that the companies would proceed to export power in violation of the state statute and then seek protection in so doing under the jurisdiction of the United States courts. Such complicated situations may readily enough arise in any of the other states. New York apparently has its 
own trouble abundantly in this regard. To what can we look forward in the future except just such a multiplication of governmental conflicts and harassments? And what else can result, save that these companies shall ultimately follow the example of the railroads in 1920, and accept full federal jurisdiction for interstate business as the lesser of two evils?

A concluding word about customer ownership as it has developed within the last decade. Its proportions are indeed prodigious. There are now approximately I,307,000 customers of public utilities who are shareholders in their respective companies; and it is reported that the sale of securities direct to such customers amounted to $\$ 296,000,000$ in 1925 - that is to say, about one quarter of the total new financing done by central station companies. Not a few of us from the outset regarded this movement as not only of doubtful value; as embodying elements of grave danger, certainly unless the movement were kept well in hand. At first it appeared as if the prime impetus came from the desire to create a more favorable public environment, to the end, for instance, that these great companies should in a lesser degree be operated in what might be called an enemy country. Unquestionably this phase of the matter under the sane and conservative management of the American Telephone Company has contributed substantially to a public understanding of the main problems confronting concerns of its particular class. Succeeding this argument, successful propaganda - and it too contains an element of truth - ran to the effect that beneficial results would flow from local coöperation and initiative. Housewives, either in the densely populated cities or out in the open, passing the time of day in neighborhood gossip, 
would perhaps keep a watchful eye upon Tony in the trenches or the lineman up aloft. Perhaps they would even report cases of inefficiency or malingering. But now the real reason has gradually thrust its head above water. It is this: that by this device of customer ownership an almost inexhaustible reservoir of new capital may be tapped; together with the further advantages that this capital may be drawn upon, not indirectly through payment of commissions to bankers, but by direct sales campaigns, through billboards and through the friendly offices (for a commission) of the meter man and the bill collector, as well as of the technical employees.

The menace of a development reaching such proportions as it has within little more than a decade arises from a number of circumstances. The first is that the creation of a great body of customer investors, while it may operate to bring about a more coöperative spirit among the people at large in matters of franchise-rate regulation and the like, may conceivably work the other way in case of mismanagement or dereliction. The seriousness of such an occurrence is fully understood by great corporations like American Telephone, which treats the matter from the high standpoint of a trustee, upon whom the direst penalties are bound to be visited in case of recreance. But in the electric-light industry, the appetite for new capital and the freedom from banking connections and chaperonage have opened the door on occasion to practices falling far below the level of trusteeship. Dewing, in his Financial Management of Corporations, concludes that the sale prices for such securities run on an average ten points above the market quotations. I personally know of an instance in New 
England, specifically cited by Dewing also, where farmers were paying seven or eight dollars a share more for such securities than the price which prevailed over the counter not far away. Such things, of course, are far and away the exception. But the greatest danger of all is the chance that some one of these great companies may go on the rocks, a fearsome thing to contemplate under such circumstances.

The president of Electric Bond and Share, an ardent advocate of customer ownership, somewhat enthusiastically describes his clientage in the Lehigh Valley anthracite coal fields as follows: -

The list of stockholders looks like the immigration roster at Ellis Island. There are all the Z's and Y's and W's imaginable, Czechoslovaks, Jugoslovaks, Poles, Greeks, Italians, Finns, Huns, and in fact practically every known nationality. We advertise in the newspapers and through circulars printed in practically all of these languages. Our socialist friends in that section are in our list of stockholders. We have something like 70,000 customers and we feel that for a long time to come we can add to our list from 500 to 1000 of these customers per month. They are averaging about three shares each. One of our Czechoslovak employees was the other day heard explaining the advantages of this stock something like this: "These are the finest shares in the world - they are not like stocks in mines, patent medicines, or flying machines, which sometimes you see but generally you don't. But with this stock push the button, and if the light shines you know your money is safe."

Some of us have known what a run was like on an East Side bank in New York. The malcontents would perhaps there number a few thousands. What would happen to one of these companies with shareholders numbered into the hundred thousands? Both the proportions and the 
character of this customer ownership movement make it clear that questions of public responsibility are involved which call for the same measure of supervision as those which for long we have been accustomed to extend to our savings banks. If for no other reason the question of submission of these great interstate holding companies to some sort of governmental supervision and control would obtrude itself upon the public view.

Another significant feature of this customer ownership movement is that it may entirely misrepresent the actual security of the investor, so far as any participation either directly or indirectly in the interstate top holding companies is concerned. The sort of deception being practised is exemplified by one of the ten "Cardinal Rules" for sales campaigns of this nature, as issued by the Customer Ownership Committee of the National Electric Light Association in 1924. One of these, by the way, reads, "The number of shareholders to be increased steadily." No doubt about its being a serious piece of business! The immediately apposite rule, however, is this: "It should be emphasized to him [the customer] that the red tape of regulation which surrounds the utility is his own best protection against any financial juggling that may affect his investment, and is as complete a guarantee of his return as can be provided for a stock issue." Such a statement is utterly false as respects the financing of any of these interstate concerns, except those hydroelectric corporations which have been licensed by the Federal Water Power Commission. Until the entire industry is placed under definite financial regulation as to security issues by an agency of the United States Government, any purchaser of securities of these top companies does so absolutely at his own peril. There 
is no supervision whatsoever, and any impression conveyed to the contrary is downright misrepresentation.

To the criticism, well deserved perhaps, that the burden of these comments tends to cast a somewhat drab and sombre hue upon the state of things electrical, three specific answers lie within grasp. The first is that, being from New England, I could not do it otherwise. I was n't born out West. Nine generations of me have risen mornings to face the chilly east winds. We of this New England breed are just so made up that, on those rare still days which ought to flood one with delight, we can but cast an anxious eye to wind'ard, treating it all as a "weatherbreeder," not as a Providential dispensation. Perhaps too there is a bit of idealism in it. Oliver Wendell Holmes was wont to divide human kind into the "if's" and the "as's." It always seemed to me that it would have been more obvious to have called them the "if only's" and the "as is's." Possibly our thoughts are not focused on earth alone, but a heaven on it is part and parcel of our dream. The second answer is that these comments are almost exclusively concerned with those recent developments associated with the rise of the great interstate holding companies. There is no reproach directed toward the industry itself, as embodied in the affairs of the underlying operating concerns. They have just been going on about their business, trying to turn out their loads day by day. As a matter of fact, these operating companies, as we have seen, are more or less adequately cared for by administrative supervision within the states - perhaps that has had more than we fully realize to do with keeping them as fine and straight as they are.

It is, then, only this newfangled top-hamper of finance 
which I would shake loose to the air and sunshine, lest mildew tinge the newness of its fabric. And then, of course, it might be observed, as an obiter dictum, that a trifle of adverse comment is not out of place, as a wholesome corrective against the full measure of self-satisfaction which could not but be expressed by those who have been responsible for so remarkable an overnight development.

The incalculable recuperative power of this lusty industry ought to be sufficient to enable it to stand a little healthy criticism now and then. This is the third answer to those who demur at our adverse comment. It is precisely because of the extraordinary achievements thus far, and of the almost limitless possibilities for expansion of service in future, that one is emboldened here and there to challenge even the policies and practices of those who have grown up with the industry and who deserve, by and large, so much credit for what has already been accomplished. It staggers comprehension to envisage the development of electrical light and power within the next generation. Even by 1934 it has been estimated competently that hydroelectric generation by itself will supply during twelve months the labor of 238,630,137 men working in three shifts of eight hours each. With but three per cent of electrical service now available to the farms of the United States, think what widespread or even universal rural electrification may mean! In another way the almost limitless possibilities of the industry must give us pause. There will be in the future a temptation, not less but rather greater than now, to trade upon the probability of continuous prosperity in respect of finance and management plans through the years to come. And the more stupendous the gain, the greater 
will be the loss in case of failure to lay foundations sound and deep. Now is the time to beware lest relatively little things get out of hand. The brakes may be set at the moment against some of these things, trusting to the innate recuperative powers of the industry to bear the shock. Beside a first-class scandal or two some day, such as the railroads have had to weather, in the past, occurrences which would shake public confidence to its depths, - how slight the harm from letting in the light seasonably, as it were, in midstream of this present flow of prosperity!

As to recommendations, several specific proposals for dealing with concrete issues are engaging. Disfranchisement of the stock of operating companies, deposited as collateral for superposed issues of holding companies, might perhaps act as a deterrent to undue corporate involvements; or the requirement by law that all public utilities engaged in interstate commerce should make their annual reports along standardized lines, and particularly that they append thereto a certified copy of their federal income tax returns. But such proposals either require uniform state legislation, which is beyond the range of possibility, or else they drive us into the arms of the Federal Government. And in any event such proposals call for precise data, in order that the legislation shall be practicable; and particularly that it shall not, in the endeavor to restrain the ill-intentioned few, operate to discourage the legitimate initiative of the many. About a hundred such things we need information. The light at present falls upon many of them in slanting shafts, due to the natural self-interest of those who now command the situation. The surest source of disinterested illumination would be a comprehensive examination into 
the whole subject of public utilities, preferably under the authority of the Federal Power Commission or some other special board temporarily created for the purpose. Consequently a wise policy at this juncture would seem to be to refrain - ostentatiously, as it were - from advocacy of any particular programme; but to urge instead that the President recommend to the Congress that provision be made for such an exhaustive inquiry, to be so prosecuted as to command the confidence of the entire country. The result would be a substantial contribution to the body of our information on a subject of profound importance at this time to some millions of the people of the United States.

These, then, are some of the things concerning which we as a nation should know more, in order wisely to proceed to the formulation of a sound public policy. Existing conditions within the industry should be analyzed, relative rates of growth of small and independent plants and of the great systems; it should be asked whether we are "overfed" on hydroelectric development at the present time or undernourished as to the tie lines; a careful census of the possibilities of widespread rural electrification should be taken; the present status of consolidation, the degree to which competitive great systems interpenetrate each other's territory, each doing business at long range uneconomically, should be examined. Operating costs deserve careful analysis, distributing the various items as between generation, transmission, and final distribution to consumers. This would throw light upon a number of fundamental problems. The relative merits of superpower, interconnection, that is, versus giant power, or concentrated power production at the mine mouth, depend largely upon such evidence. The 
economics of "teapot" or "pewee" independent generating plants, yes, the future of even the independent private industrial power plant, depends upon such relativity of production costs. Whether or not a fair field for such endeavor has been closed off by unduly low power rates to large consumers, thereby levying the deficit upon the retail householder, is a further pertinent question. This should be examined in the open with all the engineering facts disclosed. Thus the whole subject of equal electrical rate structures as against discriminatory rates for different classes of service is brought into purview.

Among the topics of first-class importance in the field of finance, to go on with this enumeration: Shall conservators be appointed for the holding companies? Is it practicable to disfranchise collateral stocks deposited under trust agreements? How should no-par stock issues be handled with regard to legislation? Is maintenance really distinguishable from depreciation; and what is the effect of differing policy in this regard upon capitalization problems? How about consolidated balance sheets, and the whole matter of promoting standardization of accounting practice? How far may financial policy really proceed upon the assumption that there will be no downward fluctuations of earnings for so rapidly developing an industry? And thus one is brought face to face with important problems in law, compounded with finance practices in promotion and construction, the activities and responsibilities of management companies, underwriting commissions, trusteeships, and the like. All of these really lead up to fundamental matters of valuation and of regulation; the promotion of greater uniformity of state regulatory statutes, the conflicting principles of rate 
regulation as between state and state. The capsheaf should be the relation of all of these things to the question of an exercise of the federal administrative power, plenary for interstate business, or coördinated with that of the different commonwealths. Shall the jurisdiction of the Federal Power Commission be amplified to include generation by steam as well as by water power, and to comprehend matters of finance and accounting as well as the determination of interstate rates? Thus will the foundation be laid for intelligent action. We stand face to face with a development precisely parallel to that through which we have passed as respects railroads, telegraphs, and telephones. It is incumbent on us to ascertain clearly whether or not these electric public utilities belong in the same class and should be subjected to the same administrative control.

A searching inquiry by real experts, not by politicians, stripped of all political bias, and affording a field day for all comers; an open contest in which the truth, regardless of self-interest, shall prevail - this is the downright need of the moment. And if the objection be advanced that the whole truth might cast a blight upon development here and there, the answer is ready at hand. It was Abraham Lincoln who was wont to emphasize "the proneness of prosperity to breed tyrants." Something like this seemed recently to be taking place in the domain of corporate management. Fortunately it was possible effectively to nip it in the bud without an iota of disarrangement. Prosperity, not real but specious, may indeed be unduly protracted by artificial means, but in the end the truth is bound to prevail. Nor can the truth work harm to those whose custom it is to work in daylight. It is the wrongdoer alone, delving in darkness 


\section{PUBLIC UTILITIES}

and diligent in deviousness, who fears the strong tonic of publicity. This brings us back, then, to where we started as respects these public utilities: and so we repeat, with Abraham Lincoln, "If we could first know where we are, and whither we are tending, we could better judge what to do and how to do it." 



\section{INDEX}

Accounts, independent audit of, I40, I4I, I42; should include balance sheet and income account, I42; publicity of, 157, I 58, I68, et seq.; maintenance and depreciation, 173, I74, I75, I 84 ; valuation of assets, I9I et seq.; need of independent audit, 197; surplus, 198, 199; holding corporations, 202, 203, 204; publicity of railroad accounts, 24I, 242, 243. See also Publicity.

Allied Chemical and Dye Corporation, I8I.

American Ice Company, I93.

American Light and Traction Company, I 24, I 25.

American Malting Company, I 72, 202.

American Sugar Refining Company, I 57, I 58, I 59, I 86.

American Waterworks and Electric Company, 282, 319, 320.

American Woolen Company, I77.

Arizona, 28, 29.

Assets, sale of, I48; valuation of, I9r, 192.

Associated Electric Company, 333, 334 .

Associated Gas and Electric Company, 312.

Atlantic City and Shore Railroad Company, 71, 72 .

Audit, need of independent, I40, I4I, I42, I 97, 21 5.

Auditing accounts under British Companies Act, I4O, I4I; in the United States, I4I, I42, I43; in Japan, I 43 .

Balance sheEts and income accounts, I 42 , I84, I90; assets, I9I et seq.; valuations on, 216,217 .

Bankers and corporation management, 90, 9I, 92.

Blackstone, Sir James, quoted, 6I, $62,74,75$.
Blue-sky laws, 218, 219.

Bond circulars, 316,317 .

Bondholders, voting rights of, 102 .

Bonds of holding companies, 3 I I, 3 I 2 , 3I4.

Boston Edison Company, 285, 335, 336.

Botany Worsted Mills, 83.

Boycotting offered securities, Io9.

Brazil Railway Company, 31, 32 .

British Companies Act, audit provisions of, $1_{4} \mathrm{O}, \mathrm{I}_{4} 2,215$.

British Controlled Oil Fields, Limited, 93.

CApital and income, I72, I73, et seq.

Capital stock, no-par, 46, 47; parvalue, 47,48 ; preferred nonvoting, 85 , 86; common nonvoting, 86, 87.

Catalysis, I 18.

Charters, statistics of, 16, 17, 18; of public utilities, 45,46 ; immortality of, 62 ; trading in, 62,63 .

Cities Service Company, 282.

Coca Cola Company, 8I.

Coke, Sir James, quoted, 6r.

Columbus Railway, Power, and Light Company, 303.

Companies Act, the, of Roosevelt, IO2.

Competence of corporations, 67, 68, 69.

Competition between states, 33, 34, 35.

Competition, Unfair, $70 n$.

Concentration of power by holding companies, 300, 301, 302 .

Conowingo hydroelectric project, 325 , 326.

Consolidated Lake Superior Company, $178,179$.

Contracts of corporations with directors, 60. 
Control through holding companies, 102, I03; pyramiding, 317 .

Cooley Engine Company, 69, 70.

Corporation fees and taxes, 34,35 .

Corporations, nature of, 4,5 ; as legal persons, 6, 7; fictions, 9 ; responsibility of, IO; responsibility of officers of, IO, II ; law of libel applied to, II ; statistics of, I6, 17, I8; English Patents of Monopoly, 20; history in U. S., 21, 22, 23, 24; bearing of our dual government system on, 24; fees and taxes, 34, 35; rights of shareholders, 38, 39, 40; underwriting subscriptions, 4I, 42; responsibility of directors, 55, 56, et seq.; contracts with directors, 60 ; immortality of charters, 62,63 ; identity of, 64,65 ; competence of, 67 , 68 , 69; holding companies, 71, 72, 73,74 ; power of majorities, 75,76 ; investment trusts, 82 ; responsibility for management, 84; nonvoting stock, 85, 86; management stock, 87,88 ; bankers and management, 90, 9I, et seq.; overelaboration in England, 92, 93; increasing number of shareholders, 95, 96; function of holding companies, 100, 10I; control by them, IO2; Roosevelt and the Companies Act, IO2; cumulative voting, 104; Michigan Corporation Law, IO5; use of floating stock, 106, 107; rise of investment trusts and investment counsel, 107; state regulation or federal control of public utilities, II 3 , I14; a Federal Power Commission, II 4 ; federal incorporation or federal license a possibility, I1 5 , I16; disfranchisement of shareholders, I I9, I20, I2I ; attitude of Investment Bankers Association, 122; electric light and power companies, 123, 124, 125, 126; federal income tax law and disfranchisement of preferred shareholders, I 26, I27; conflicts between shareholders, 127, 128; insurance companies, 128; democratization of management, I29, I30; representation of labor, 137; organization among directors, 138 ; independent audit of accounts, I4O, I4I, I42; balance sheets and income accounts,
142; representation of shareholders, 144, 145; funds for improvement, and subscription rights, I44; conducting meetings, 145 ; proxies, 145 , 146, 147; dividend policy, I49, I 50 ; directors' liability, 152, 153; publicity of accounts, 157,158 ; stockholders' experiences, $160,161,162$; annual reports, 162, 163, et seq.; the trust question, 167; open market quotations, 169, 170; capital and income, 171, 172, et seq.; depreciation, 174, 175; reserves, 179, 180, et seq.; income accounts, 184 ; net earnings statements, 188, 189; balance sheets, 190, 19I, et seq.; goodwill, 192, I 93 ; surplus, I 98, I 99; consolidated statements, need of, 203 , 204; publicity and speculation, 204, 205; publicity requirements of New York Stock Exchange, 210 et seq.; shareholders' function in securing publicity, 214, 215, 216; federal legislation, 220; federal license, 221, 222; Federal Trade Commission, 223 et seq.; railroads, 239-275; public utilities, 276-353.

Corruption, political, $35,36,37$.

Customer ownership, $343,344,345$.

Delaware, $17,30$.

Democratization of management, 129 , I30.

Dennison Manufacturing Company, I35.

Depletion, 173.

Depreciation, 173 and $n ., 174,175$.

Dewing on electric-light securities, 344, 345.

Di Giorgio Fruit Corporation, 196, I97, 198.

Directors, responsibility of, 55 et seq.; contracts of, with corporations, 60; liability for mismanagement, 100 , 152; organization among, 138; executive committees, 138 .

Disfranchisement of shareholders, 119 , 120, I21; and the income tax law, 126, 127 .

Dividend policy, 149, 150.

Divorce laws, 26, 27.

Dodge Brothers, Incorporated, 86, 87, 194, 195, 199, 200, 201. 
Earnings, net, statements of, I88, 189.

Electric Bond and Share Company, 345 .

Electric light and power companies, I 23, I 24, I 25, I 26.

Employers' liability legislation, 27, 28.

England, overelaboration of corporate organization in, 92, 93; accounting practice in, 134, I40, I 4 I, 142, 143 .

Excess reserves, 179, 180, et seq.

Executive committees, I38, I39.

Federal control of public utilities, $339,340$.

Federal legislation on publicity, 220.

Federal license, 221 .

Federal Power Commission, I I4, 325.

Federal Trade Commission, I I 5, 222, 223; price fixing, 223, 224; court decisions, 224, 225; publicity powers of, 226 et seq.

Fees and taxes, corporation, 34, 35 .

Ferguson, president Association of Edison Illuminating Companies, $327,328$.

Fictions, corporate, 9, 63, 64 .

Finance, public, conflict of laws, 25 .

Fraud, prevention of, 218.

GoodwILL, 192, 193, 21 I.

Governmental system, dual, in U. S., $24,25,26,27,28$.

Great Britain, accounting practice in, I34, I4O, I41, I42, I43.

Havemeyer, H. O., 158, 159.

Holding corporations, 71,72 ; history of law regarding, 73,74 ; and exchange of shares, 96, 97; control through, IO2; accounts of, 202, 203; advantages of, 290, 29I, 292; defects of, 292; some holding-company hierarchies, 293, 294, et seq.; reason for holding companies, 296, 297, et seq.; simplification of, 299, 300; to concentrate control, 300, 301, 302; the Slaymaker case, 303; involved finances of, 304, 305; overextension of, 305, 306; reports of, 306, 307, 308; and rates, 309; bonds of, 311 , 3I 2, 3I4, 316, 317; pyramiding control, 317; financial complexity, 322, 323; deceptive income accounts,
331, 332; depreciation policy, 333, 334 .

ILLINoIS, 17.

Impublicity, 208-228. See also Publicity.

Income accounts and balance sheets, I42, I71, 172, et seq.

Income and capital, 172, 173, et seq.

Income statements, quarterly, 189 .

Income tax law and disfranchisement of shareholders, I 26, 127.

Incorporation, statistics of, I8; competition between states, 33; federal incorporation, 222.

Industrial Rayon Corporation, 87.

Initial surplus, 52 .

Installment buying, $175,176$.

Insull group of public utilities, 28I, 283.

Insurance companies, 128.

Investment Bankers Association of America, I I 2, I 22, 208, 308, 31 2, 313, 316.

Investment counsel as a profession, 107, 108.

Investment trusts, 82, 107, 108, 109.

JAPAN, publication of accounts in, 143 . Jurisdictions, overlapping, 28.

LABOR Legislation, 27, 28.

Labor, representation for, 137 .

Lehigh and Wilkes-Barre Coal Company, 170.

Liability, employers', 27, 28.

Liability of directors, 55 et seq., 100, 152.

Libel, law of, applied to corporations, II.

Loree, president Delaware and Hudson Railroad, 269.

MAINE, incorporation in, 3I, 32; waterpower situation in, 342 .

Maintenance, I73.

Majority, power of, $75,76,77$.

Management, democratization of, 129 , I30.

Management stock, 87,88 .

Market prices, I69, I70, 219.

Marriage laws, 26.

Massachusetts, 17.

Michigan Corporation Law, 105, 218. 
Middle West Utilities Company, 330, 331.

Minority rights, 13,76 .

Monopoly, English Patents of, 20, 21.

National Biscuit Company, i80.

National Cash Register Company, 70, 71,199 .

National Electric Light Association, 346.

National Public Service Corporation, 315.

Nevada, 29.

New. England Navigation Company, 63.

New England Oil Corporation, 152.

New Jersey, 17.

New York (State), 17, 219.

New York Stock Exchange, 187, 188, 210, 220.

No-par stock, 43, 44, 46, 47, et seq., I94, 195, I96; accounting, 197; and surplus account, 199, 200, et seq.

Nonvoting stock, $[85,86,97,98,119$, I 20, I2I, I 22, I23.

Northeastern Power Company, 283, $295,326$.

Northern Securities Company, 63.

Northern States Power Company, 30r.

Obsolescence, I $73, \mathrm{I} 76$.

Ohio, 17.

Open market quotations, $169,170$.

Operating companies, finance of, 310 , 3 II.

Partnerships, 5; disappearing, I9.

Par-value stock, 47, 48.

Passes, railroad, 235, 236 .

Patents of Monopoly, English, 20, 21.

Pennsylvania, I7.

Pennsylvania Giant Power Board, 327.

Philadelphia Company, the, 173 .

"Plural voting" shares, 106.

Political corruption, 35, 36, 37, 340, 34 I.

Preferred shares, 85, 86; nonvoting, 122, 123.

Prices, fair market, 169, 170, 219.

Public utilities, charters of, 45,46 ; liability of directors, $58,59,60$; nonvoting stock, 90, 97, 98; regulation of, $\mathrm{II}_{2}, \mathrm{II}_{3}$; state regulation vs. federal control, II3, II4; elec- tric light and power, 123, 124; accounts of, 203, 204; recent development of, $276,277,278$; political corruption by, 278, 279, 280; combinations among, 280, 28I, 282; supercombination among utilities, 282,283 ; diversification of risk, 284 ; costs of production, 285 ; cost analysis among utilities, 285, 286; limits to combinations, 286, 287; public utility rates, 287,288 ; independent generating plants, 288, 289; hydroelectric development, 289, 290; advantages of holding companies, 290 et seq.; defects of holding companies, 292; some holding-company hierarchies, 293, 294, et seq.; concentration of power, $300,301,302$; capital structure of, 302 ; involved finances of, 304, 305; reports of public utilities, 306, 307, 308; holding companies and rates, 309; finances of, 310 et seq.; operating companies, $3 \mathrm{IO}, 3^{\mathrm{II}}$; bonds, holding-company, 3I I, 3I 2, 3I4; preferred stock, $3^{\mathrm{I}} 3$; pyramiding control of, 317; sensitive returns for (statistics), 319; stable returns, 32I, 322; financial complexity of top companies, 322,323 ; stock watering, 324 ; competitive bidding among, 326,327 ; padding income accounts, $328,329,330$; deceptive income accounts, 33I, 332, 333; overcapitalization, 333; depreciation policy, 333 , 334; reserve for depreciation, 334 , 335; valuation of public utilities, 336, 337; administrative control, 337, 338; regulation by state, 338, 339; federal control of, 339, 340 ; political influence in, $340,34 \mathrm{I}$; New England conference (I926), $34 \mathrm{I}, 342$; waterpower situation in Maine, 342 ; future of public utilities, 348,349 ; investigation needed, $349,350,35 \mathrm{I}, 352,353$.

Publicity, 156, 157; history of, 157 , 158,162 , et seq.; and efficiency, 166 , I67; real reason for, I68, 169, I70; and speculation, 204, 205, et seq.; under competition, 209, 210; requirements of New York Stock Exchange, 210; listing requirements, 2II, 212, 213; shareholders' 
function in, 214, 215, 216; federal legislation, 220; Federal Trade Commission, 222, 223; court decisions, 224; powers of Federal Trade Commission, 226, 227; railroad accounts, 24I, 242, 243; need in connection with public utilities, 349 et seq. See also Accounts and Auditing.

Pujo Senate Committee Report, 128.

Quotations, open market, 169, 170.

RAILROADS, shareholders in, 229, 230; construction, regulation of, 233 , 234 ; politics and, $234,235,236,237$; speculation, 237,238 ; rates, 238 ; financial regulation of, 239,240 , et seq.; reorganization of, $240,24 \mathrm{I}$; publicity of accounts, 24I, 242, 243; dividend policy, 243,244 ; valuation of, 244,245 ; reasonable returns for, $245,246,247$; fixed charges on, 247, 248 ; reasonable rates, $249,250,251$; Transportation Act, 250,251 ; consolidation, 251, 252, 253; trunk lines (map), 256; anthracite coal roads, $26 \mathrm{I}, 262$; trunk-line consolidation (1926), 263, 264; Nickel Plate system, 263,264 ; terminals, 269; Loree project, 269, 270; consolidation leadership needed, 270 , 271 , et seq.

Rates, railroad, 238, 245, 246, 247 , 249, 250, 251.

Reports, annual, 162,163 , et seq.; delay of, 183, 184; of public utilities, 306, 307, 308 .

Representation committees, 133 ; for labor, 137 .

Reserves, excess, 179, 180, et seq.

Responsibility of corporations, ro; of their officers, IO, II; of directors, 55 et seq., $100,152$.

Roosevelt, Theodore, and the Companies Act, 102.

Shaffer Oil and Refining ComPANY, 332.

Shareholders, rights of, $3^{8}$; subscription rights, 38 ; preëmptive rights, $38,39,40$, et seq.; increasing number of, 95,96 ; disfranchisement of, I19, I20; conflicts between, I 27, 128; representation of, 133 ; their rights, I44; their proxies, I45; education of, 154 ; function in publicity, 214; representation, 215; in railways, 229,230 .

Shareholders' representation, 133; and rights, I44; proxies, 145; sale of assets, 148; dividend policy, 149; liability of directors, 152 .

Slaymaker case, the, 303 .

Solomon and Company, Limited, 64.

South Dakota, 29.

Speculation, and publicity, 204, 205, et seq.; railroad, $237,238$.

Standard Gas and Electric Company, 281, 282, 305, 306, 331, 332.

Steel Corporation Bond Conversion, $36,37$.

Stock watering, 324,325 .

Stockholders, the minority, I3; subscription rights of, $38,39,40$; increasing number of, 95, 96. See Shareholders.

Stocks, no-par, $43,44,46,47$, et seq.; par-value, 47,48 ; preferred, 85,86 ; common nonvoting, 86,87 ; management, 87, 88, 90; floating, 106, I07; nonvoting, I19, I 20, 121 .

Subscriptions, underwriting, 4I, 42.

Surplus, initial, 52; in reports, 198, 199, 200, 201, et seq.; of railroads, 239, 240.

TAXES and fees, corporation, 34, 35 .

Temple Iron Company, 63.

Transportation Act (1920), 250, 251 .

Trust question, the, 167 .

Trusts, private, 82 ; investment, 82.

UNDERWRITING subscriptions, 41, 42. Unfair Competition, $70 \mathrm{n}$.

United Light and Railways Company, 301.

United States Rubber Company, I86, 187.

United States Steel Corporation, 164, $165,206$.

Utilities, public. See Public utilities.

Valuations on balance sheets, 216, 217.

Virginia, 33.

Voting, cumulative, 104, 106;"plural," Io6.

Voting rights, $84 n$.

Willett-Sears case, the, 152. 


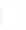




